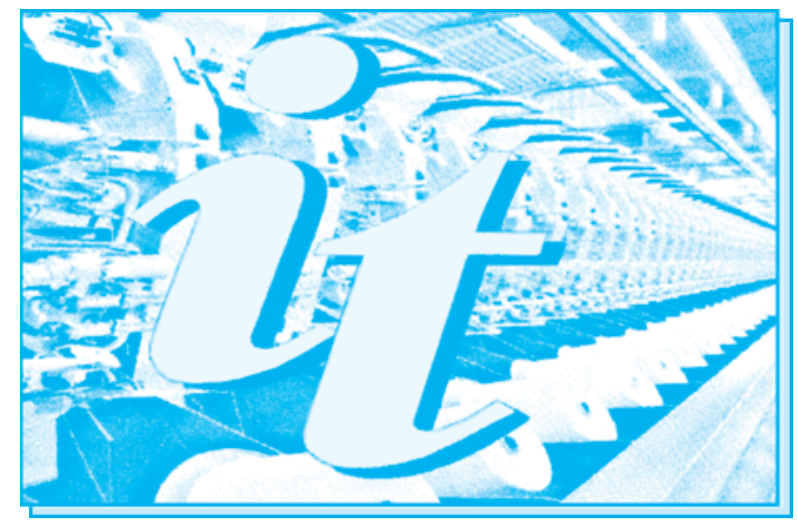

Revistă cotată ISI si inclusă în Master Journal List a Institutului pentru Știința Informării din Philadelphia - S.U.A., începând cu vol. 58, nr. $1 / 2007 /$

ISI rated magazine, included in the ISI Master Journal List of the Institute of Science Information, Philadelphia, USA, starting with vol. 58, no. 1/2007

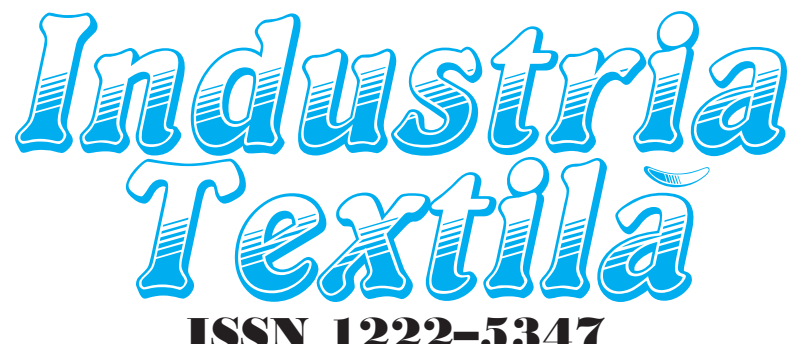

ISSN 1222-5347

$5 / 2012$

Editată în 6 nr./an, indexată și recenzată în:

Edited in 6 issues per year, indexed and abstracted in: Science Citation Index Expanded (SciSearch ${ }^{\circledR}$ ), Materials Science Citation Index ${ }^{\circledR}$, Journal Citation Reports/Science Edition, World Textile Abstracts, Chemical Abstracts, VINITI, Scopus, Toga FIZ technik ProQuest Central

\section{COLEGIUL DE REIDACTIE:}

Dr. ing. CARMEN GHITULEASA CS I - DIRECTOR GENERAL Institutul Naţional de Cercetare-Dezvoltare pentru Textile şi Pielărie - Bucureşti

Dr. ing. EMILIA VISILEANU CS I-EDITOR SEF

Institutul Naţional de Cercetare-Dezvoltare pentru Textile şi Pielărie - Bucureşti

Conf. univ. dr. ing. MARIANA URSACHE DECAN

Facultatea de Textile-Pielărie şi Management Industrial, Universitatea Tehnică „Ghe. Asachi“ - laşi

Prof. dr. GELU ONOSE CSI

Universitatea de Medicină şi Farmacie "Carol Davila" - Bucureşti

Prof. dr. ing. ERHAN ÖNER Marmara University - Turcia

Prof. dr. S. MUGE YUKSELOGLU Marmara University - Turcia

Prof. univ. dr. DOINA I. POPESCU Academia de Studii Economice - Bucureşti

Prof. univ. dr. ing. CARMEN LOGHIN Facultatea de Textile-Pielărie şi Management Industrial, Universitatea Tehnică „Ghe. Asachi“ - laşi

Prof. univ. dr. MARGARETA STELEA FLORESCU Academia de Studii Economice - Bucureşti

Prof. ing. ARISTIDE DODU

Membru de onoare al Academiei de Ştiinţe Tehnice din România

Prof. dr. ing. LUIS ALMEIDA

University of Minho - Portugal

Prof. dr. LUCIAN CONSTANTIN HANGANU Universitatea Tehnică „Ghe. Asachi“ - laşi

\section{Dr. AMINODDIN HAJI}

PhD, MSc, BSc, Textile Chemistry and Fiber Science Assistant Professor

Textile and Art Department Islamic Azad University, Birjand Branch Birjand, Iran
ESRA AKGÜL, EMEL KIZILKAYA AYDOĞAN, MIHRIMAH ÖZMEN, HÜSEYIN GAZI TÜRKSOY

Optimizarea parametrilor mașinii de filat Vortex Murata prin metoda SMAA-MOORA

RAZVAN SCARLAT, LEONARD RUSU, FLOAREA PRICOP

Agrotextile tricotate pentru o agricultură sustenabilă

EMILIA VISILEANU, CARMEN MIHAI, ADRIAN SALISTEAN,

ALEXANDRA ENE, SABINA OLARU

Aplicarea sistemelor informatice în realizarea bandajelor pentru ortopedie 337-342

LIN-IIN YAN, LIN-MIN ZHU, ZHUAN-YONG ZOU, LIAN-YIN ZHAO,

ZHOU JIAN-DI, DANG-PING ZHU

Efectul de adsorbție și de decolorare a cărbunelui activ din nucă de cocos pentru apele reziduale rezultate în urma procesului de vopsire cu coloranti de dispersie

CARMEN GAIDAU, MIHAELA-DOINA NICULESCU, TODORKA G. VLADKOVA, LILIOARA SURDU, IONEL BARBU, PETER DINEFF

Cercetări privind tratamentul cu plasmă rece a materialelor din piele şi blană ca alternative ecologice

\section{RIZA ATAV}

Modificarea chimică a țesăturilor de in pentru vopsirea fără săruri cu coloranți anionici

LILIANA INDRIE, ZLATINA KAZLACHEVA, JULIETA ILIEVA,

SABINA GHERGHEL

Broderia - de la design digital la artă

EMINE UTKUN, NEZLA ÜNAL

Îmbunătățirea ajustării pe corp a uniformelor de lucru din laboratoare și ateliere de lucru

NICOLETA ANDREEA NEACȘU, CODRUȚA ADINA BĂLTESCU,

\section{SIMONA BĂLĂȘESCU, DANẢ BOȘCOR}

Influenţa elementelor de design şi estetică în alegerea îmbrăcămintei

CRISTINA DIMA, LIANA BADEA, AMALIA CRISTESCU

Percepţia consumatorilor privind comercializarea în România a brandurilor de haine contrafăcute. Studiu pilot - regiunea de Sud și Bucureşti

SNEŽANA UROŠEVIĆ, DARKO RADOSAVLJEVIĆ, VIOLETA STEFANOVIĆ, DRAGAN ĐORĐEVIĆ, GORDANA KOKEZA

Clasificarea multicriterială a locurilor de muncă prin metodele ELECTRA pentru îmbunătățirea analizei și a condițiilor de lucru în cadrul companiilor din industria textilă

EDA ACAR, PELIN OFLUOĞLU, SEHER KANAT, ZÜMRÜT BAHADIR ÜNAL, TURAN ATILGAN

Analiza comportamentului de cumpărare al consumatorilor de îmbrăcăminte de mari dimensiuni în comerțul electronic

Recunoscută în România, în domeniul Științelor inginerești, de către Consiliul Național al Cercetării Științifice din Învățământul Superior (C.N.C.S.I.S.), în grupa A /

Aknowledged in Romania, in the engineering sciences domain, by the National Council of the Scientific Research from the Higher Education (CNCSIS), in group $A$ 


\section{Contents}

MESRA AKGÜL, EMEL KIZILKAYA

AYDOĞAN, MIHRIMAH ÖZMEN,

HÜSEYIN GAZI TÜRKSOY

\section{RAZVAN SCARLAT, LEONARD RUSU, FLOAREA PRICOP}

EMILIA VISILEANU, CARMEN MIHAI, ADRIAN SALISTEAN, ALEXANDRA ENE, SABINA OLARU

LIN-IIN YAN, LIN-MIN ZHU, ZHUAN-YONG ZOU, LIAN-YIN ZHAO, ZHOU JIAN-DI, DANG-PING ZHU

CARMEN GAIDAU, MIHAELA-DOINA NICULESCU, TODORKA G. VLADKOVA LILIOARA SURDU, IONEL BARBU, PETER DINEFF

RIZA ATAV

LILIANA INDRIE, ZLATINA KAZLACHEVA, JULIETA ILIEVA, SABINA GHERGHEL

EMINE UTKUN, NEZLA ÜNAL

NICOLETA ANDREEA NEACȘU, CODRUTA ADINA BĂLTESCU, SIMONA BĂLĂȘESCU, DANA BOȘCOR

CRISTINA DIMA, LIANA BADEA, AMALIA CRISTESCU

SNEŽANA UROŠEVIĆ, DARKO RADOSAVLJEVIĆ,

VIOLETA STEFANOVIĆ, DRAGAN ĐORĐEVIĆ, GORDANA KOKEZA

EDA ACAR, PELIN OFLUOĞLU, SEHER KANAT, ZÜMRÜT BAHADIR ÜNAL, TURAN ATILGAN

\section{Optimization of the Murata Vortex Spinning machine parameters by the SMAA-MOORA approach}

Knitted agrotextiles for a sustainable agriculture

Applying computer systems to make orthopedic bandages

Adsorption and decolorization effect of cocoanut activated carbon for simulated

disperse dye wastewater

Research on cold plasma treatment of leather and fur based materials as ecological alternative

Improving fit of work uniforms used in laboratories and workshops

The influence of design and aesthetics elements in choosing clothing

Consumer perception concerning the trade of counterfeit clothing brands in Romania. A pilot study - Southern region and Bucharest

Multicriteria ranking of a job positions by ELECTRA methods in order to improve the analysis and conditions at work in companies in the textile industry

\section{Scientific reviewers for the papers published in this number:}

DušanTrajković - Faculty of Technology, Leskovac, Serbia. e-mail: dusant@excite.com

Goran Demboski - University "Ss. Cyril and Methodius", Faculty of Technology and Metallurgy, Skopje, Macedonia. e-mail: goran@tmf.ukim.edu.mk

N. N. Brito - Goiás Federal University, Brasil. e-mail: nubiabrito@ufg.br

Tulay Gulumser - Department of Textile Engineering, Faculty of Engineering, Ege University, İzmir, Turkeytulay. e-mail: gulumser@ege.edu.tr

Zoran Stjepanovic - University of Maribor, Faculty of Mechanical Engineering, Smetanova, Maribor, Slovenia. e-mail: zoran.stjepanovic@um.si

Zlatina Kazlacheva - Faculty of Technics and Technologies, Yambol, Trakia University, Bulgaria. e-mail: z_kazlacheva@abv.bg Miloš Sorak - Faculty of Technology Banja Luka, University of Banja Luka, Bosnia and Herzegovina. e-mail: sorakmilos@yahoo.com

\section{EDITORIAL STAFF}

Editor-in-chief: Dr. eng. Emilia Visileanu Graphic designer: Florin Prisecaru e-mail: industriatextila@certex.ro

Journal edited in colaboration with Editura AGIR, 118 Calea Victoriei, sector 1, Bucharest, tel./fax: 021-316.89.92; 021-316.89.93; e-mail: editura@agir.ro,www.edituraagir.ro 


\title{
Optimization of the Murata Vortex Spinning machine parameters by the SMAA-MOORA approach
}

\author{
DOI: 10.35530/IT.068.05.1267
}

\section{REZUMAT - ABSTRACT}

\section{Optimizarea parametrilor mașinii de filat Vortex Murata prin metoda SMAA-MOORA}

\begin{abstract}
Mașina de filat Vortex Murata (MVS) a atras rapid atenția producătorilor de fire datorită capacității acesteia de filare a fibrelor de 100\% bumbac la viteze foarte mari. Mulți cercetători au studiat abordările statistice pentru a selecta parametrii adecvați ai mașinii MVS pentru realizarea firelor dorite. Cu toate acestea, optimizarea parametrilor mașinii rămâne o problemă de luare a deciziilor multi-criteriale. În această lucrare, a fost propusă o nouă metodă, SMAA-MOORA, prin integrarea Analizei Acceptabilității Multi-Criteriale Stochastice (SMAA) și Optimizării Multi-Obiective pe baza metodelor de analiză a raportului (MOORA) pentru a determina presiunea optimă a duzei și viteza mașinii MVS pentru firele de bumbac. Datorită SMAA-MOORA, metoda MOORA este aplicabilă cu date stochastice, ceea ce înseamnă date incerte. Acest studiu arată că SMAA-MOORA oferă rezultate SMAA mai sigure și mai precise.
\end{abstract}

Cuvinte-cheie: fir filat pe mașina MVS, luarea deciziilor multicriteriale stochastice, Analiza Acceptabilității, metodologia MOORA

Optimization of the Murata Vortex Spinning machine parameters by the SMAA-MOORA approach

Murata Vortex Spinner (MVS) has quickly captured the attention of staple yarn producers due to its ability of spinning $100 \%$ cotton fibers at very high speeds. Many of researchers have been studied statistical approaches to select appropriate MVS machine parameters for producing of desired yarn. However, optimization of machine parameters is a multi-criteria decision making problem. In this paper we proposed a new method, SMAA-MOORA, by integrating the Stochastic Multi-Criteria Acceptability Analysis (SMAA) and Multi-Objective Optimization on the basis of Ratio Analysis (MOORA) methods to determine the optimum nozzle pressure and delivery speed of MVS machine for cotton yarn. Thanks to SMAA-MOORA method MOORA method is applicable with stochastic data means uncertain data. This paper shows that SMAA-MOORA gives more confident and accurate SMAA results.

Keywords: MVS spun yarn, Stochastic Multi-criteria Decision Making, Acceptability Analysis, MOORA methodology

\section{INTRODUCTION}

Production of staple yarn is carried out by three major spinning technologies; ring spinning (RS), open-end rotor spinning (OERS) and air jet spinning. Air jet spinning technology which is one of these systems has been commercialized since the early 1980s [1]. Initially, the acceptable quality, particularly from the point of yarn strength, has been able to be achieved in the processing of manmade fibers and manmade fibers blended yarns with air jet spinning.

MVS is the latest development in air jet spinning technology and the most commercially successful air-jet spinning machines, which was firstly demonstrated at Osaka International Textile Machinery Show OTEMAS'97 by Murata Machinery Limited. This new spinning technology uses air vortex which is created in a special nozzle block to form the air jet spun yarn.

MVS method has quickly attracted the interest of staple yarn producers due to its ability of spinning $100 \%$ cotton yarn at very high speeds [2]. According to literature, as a distinct from conventional yarn spinning technology, unique MVS yarn and fabrics have several advantages including low hairiness, remarkable pilling and abrasion resistance, high moisture capacity, fast drying characteristics, and the more durability enabling high functionality for a long time [3].

MVS yarn properties depend on not only raw material characteristics, but also MVS machine spinning parameters such as delivery speed, nozzle air pressure, distance between front roller nip point and spindle, draft, nozzle angle, spindle diameter, spindle working period, spindle type (cross section) and so on. These parameters have an influence on yarn evenness, imperfections, hairiness and tensile properties of MVS yarn [4].

In the literature, Basal and Oxenham investigated the effects of MVS machine parameters on the structure and properties of $100 \%$ carded cotton vortex spun yarns. They concluded that hairiness decreases with the lower yarn delivery speed and higher nozzle pressure. Also, values of tensile properties of MVS yarn decrease with increased delivery speed [5]. Ortlek and Ulku examined the effects of nozzle pressure and delivery speed in $100 \%$ carded cotton vortex spun yarns with different yarn number. Their findings show that increasing the delivery speed increases hairiness and decrease the number of neps, and the tensile properties of MVS yarns. When the nozzle pressure decreases, yarn unevenness, 
the number of thick places, the neps values, and the tensile properties of MVS yarns decreases but the hairiness values of MVS yarns increases [6]. Tyagi and Sharma discussed the effect of machine parts and fiber combination on characteristics of polyestercotton yarns spun on MVS. They reported that increase in delivery speed causes deterioration in yarn's structural integrity and leads to a decrease in abrasion resistance of MVS yarns. In addition they reported that increase in nozzle air pressure leads to improvement in structural integrity, increase in abrasion resistance of MVS yarns [7].

It was observed that most of researchers used generally classic statistical methods to examine the effect of various spinning parameters on yarn quality [5-8]. On the other hand, optimum MVS machine parameters selection among possible alternatives with different properties and performance levels is a basically a multicriteria decision-making (MCDM) problem. Many researchers used some application of MCDM methods for different spinning systems [9-16]. Majumdar, Sarkar and Majumdar determined that the quality value of cotton by using different MCDM approaches [9]. Valipour and Mogahssam used preference ranking organization method for enrichment of evaluations (PROMETHEE) for selecting suitable drawing frame variables for $\mathrm{Ne} 30$ rotor spun yarn [10]. Polonka and Ogunski used MCDM for the selection of the best variant of the manufacturing process of a spindle with a collapsed balloon crown of a ring spinning frame [11]. Majumdar, Kaplan, Araz and Goktepe applied AHP, Technique for Order Preference by Similarity to Ideal Solution (TOPSIS) and ELECTRE methods for selection of suitable rotor navel [12-13]. Moghassem and Bahramzadeh used TOPSIS to determine convenient doffing tube components and feasible alternatives were ranked according to the yarn parameters [14]. Moghassem compared performance of TOPSIS and VIse Kriterijumska Optimizacija I Kompromisno Resenje (VIKOR) methods for suitable spinning condition for rotor spun yarn [15].

In this paper we propose a model to apply stochastic multi criteria decision making problems for selection of MVS machine parameters. The proposed SMAAMOORA, using MOORA and SMAA-2 together, is an integrated approach of these methods. Thanks to SMAA-MOORA stochastic decision problems can be applicable by using, an effective and popular MCDM method, MOORA. However, there is no published literature that focuses on selection or ranking alternatives using MCDM in the vortex spinning machine parameters. Therefore, in this study, we have applied SMAA-MOORA approach to select the appropriate nozzle pressure and delivery speed for MVS yarn with the best quality parameters to use in circular weft knitting machine.

\section{MATERIALS AND METHODS}

Cotton fiber with 4.45 micronaire reading, $27.89 \mathrm{~mm}$ $2.5 \%$ span length, uniformity ratio of 46.6 , uniformity index of $82.6,5.2 \%$ breaking elongation, and 28.81 $\mathrm{g} / \mathrm{tex}$ strength was used as a raw material for producing yarn samples. Cotton fibers were furnished as a three passage of drawing process in order to develop fiber alignment and sliver evenness. After three passages, the slivers were linear density of $2.48 \mathrm{ktex}$ to produce Ne 30 yarn on the MVS 851 machine.

There were two main parameters in MVS machine including three levels of nozzle pressure 4, 5, 6 $\mathrm{kgf} / \mathrm{cm}^{2}$, three levels of delivery speed 300, 350, 400 $\mathrm{m} / \mathrm{min}$. Specification of the nine different yarn samples produced according to the above mentioned variables have been shown in table 1 .

The irregularity and hairiness characteristics of the yarns were tested on an Uster Tester 4 SX. The RKM and elongation of yarns were analyzed with an Uster Tensorapid 3 with a sample of $500 \mathrm{~mm}$ was elongated at an extension rate of $500 \mathrm{~mm} / \mathrm{min}$.

\section{The methodology of SMAA-MOORA}

The MOORA is a deterministic MCDM method and needs parameters like weights of criteria and evaluations of the alternatives on the considered criteria. Evidently the parameter values affect the result of MOORA. In some cases the relative importance of the criteria doesn't known and in such cases deterministic method MOORA cannot apply. When the criteria of the weight are unknown and the criteria measurements are the stochastic to apply knowledge effectively MOORA, we propose a new method SMAA-MOORA. In literature SMAA was previously applied methods of decision-making, especially ELECTRE methods and there are integration of PROMETHEE and TOPSIS method although implementation is not found in the literature with MOORA which can be applied easier and has more consistent results than other MCDM methods [16-22]. SMAAMOORA is the integration of the SMAA-2 and MOORA methods. In the SMAA-MOORA instead of SMAA-2's own original utility function the MOORA is located.

\section{The MOORA}

The MOORA is first introduced by Brauers [23]. It is a method to solve different MCDM problems which consist of two or more conflicting attributes (objectives) subject to certain constraints. Also Chakraborty used most widely MCDM methods and compared them with MOORA. According to Chakraborty's study the MOORA, is even easier and has more consistent results than the others due to the type of information required by the application and calculation feature [24].

There are different variations of MOORA method in literature:

- Ratio System of MOORA

- Reference Point Approach of MOORA

- MOORA Significance Coefficient

- MULTI MOORA

The MOORA method starts with a decision matrix showing the pertinent evaluation attributes for different alternatives. Then, a ratio system is developed, 
where each performance of an alternative on an attribute is to be compared with the representative for all the alternatives. Next, the overall performance of each alternative is calculated as the difference between sums of its normalized performances for beneficial attributes (maximization) and non-beneficial attributes (minimization). An ordinal ranking shows the final preference. Thus, the best alternative has the highest value, while the worst alternative has the lowest value [33].

In this study Reference point approach of MOORA is combined with SMAA. So it is explained below:

Consider a decision matrix $X$ with a set of alternatives $A$ with a set of criteria $G=\left\{g_{1}, g_{2}, \ldots, g_{n}\right\}$.

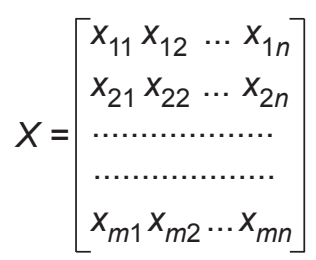

where $x_{i j}$ is the performance measure of $i^{\text {th }}$ alternative on $f^{\text {th }}$ attribute, $m$ is the number of alternatives, and $n$ is the number of attributes. $x_{i j}^{*}$ is the normalized values of performance measure.

$$
x_{i j}^{*}=\frac{x_{i j}}{\sqrt{\sum_{j=1}^{m} x_{i j}^{2}}}
$$

The Reference Point Approach of MOORA based on distance to the reference point. The reference point $R=\left\{r_{1}, r_{2}, \ldots, r_{n}\right\}$ represents the best value of the each criterion among all the alternatives. Distance from these determined points for every $x_{i j}^{*}$ is given by:

$$
\left(r_{i}-x_{i j}^{*}\right)
$$

The matrix is subject to the process "Min Max Metric of Tchebycheff" that is given in formula (4).

$$
\min _{i} \max _{j}\left(\left|r_{i}-x_{i j}^{*}\right|\right)
$$

\section{The SMAA-2}

There are a lot of MCDM approaches which are interested in real life decision making difficulties. The most successful ones are utility function based methods and these methods need crisp data to evaluate problems. But in many MCDM problems decision makers are faced with cases where they cannot obtain preference information for various reasons [25]. Thus they cannot reach crisp data. The way to cope with this challenge is defining result values for different outputs instead of asking parameter values. SMAA is proposed with this approach [26].

SMAA is a family of MCDM methods which include incomplete, certain and ambiguous data [26, 28]. Different SMAA methods can usable for three main MCDM problem case (choosing, sorting and ranking). Additionally the methodology considers these cases in a broad sense. For example SMAA-2 gives probability of alternatives' ranks instead exact ranks. The methodology is based on the inverse analysis of the appropriate parameter values space. And the advantage of SMAA is to not use preference information.

SMAA-2 has been proposed for cases where neither criteria measurements nor weights are precise. And also SMAA-2 is an extended form of SMAA including all ranges and new measurements. The new measurements enable decision makers to make better predictions [27]. Therefore a ranking function defined as:

$$
\operatorname{rank}\left(i, \xi_{,} w\right)=1+\sum_{k \neq i} \rho\left(u\left(\xi_{k}, w\right)>u\left(\xi_{i}, w\right)\right)
$$

where $\rho$ (true $)=1$ and $\rho$ (false $)=0$. Then analyzing the stochastic sets of favorable rank weights as follows:

$$
W_{i}^{r}(\xi)=\{w \in W: \operatorname{rank}(i, \xi, w)=r\}
$$

The SMAA-MOORA measurements are described below:

The rank acceptability index $b_{i}^{r}$ displays the share of alternative $x_{i}$ parameter values of being rank $r$. The rank acceptability gets values in the range [0 1] where 0 denotes that alternative never obtain given rank and evidently 1 denotes that the given rank always with any choice of weight.

$$
b_{i}^{r}=\int_{\xi \in x} f_{x}(\xi) \int_{w \in W_{i}^{r}(\xi)} f_{w}(w) \mathrm{d} w \mathrm{~d} \xi
$$

The rank acceptability index $b_{i}^{1}$ indicates the first rank and the acceptability index $a_{i}$ are equal to each other. Before making decision to aggregate rank acceptability indices when the number of alternatives too that could work to eliminate weak alternatives. The $k$ best rank acceptabilities as:

$$
a_{i}^{k}=\sum_{r=1}^{k} b_{i}^{r}
$$

The central weight vector $w_{i}^{k}$ is providing the criteria preference information of a typical DM judging of the favorable first rank of an alternative.

$$
w_{i}^{k}=\frac{1}{a_{i}} \int_{\xi \in x} f_{x}(\xi) \sum_{r=1}^{k} \int_{w \in W_{i}^{r}(\xi)} f_{w}(w) w d w d \xi
$$

The confidence factor $p_{i}^{k}$ gives information about the possibility of an alternative taking part in first rank with selected central weight vector.

$$
p_{i}^{k}=\int_{\xi \in X: u\left(\xi_{i}, w_{i}^{k}\right) \geq u\left(\xi_{k}, w_{i}^{k}\right)} f_{x}(\xi) d \xi
$$

The confidence factors indicate that accuracy of the criteria value to recognize the alternative. And also evaluating together with the confidence factors and the rank acceptability index would be meaningful to eliminate weakly efficient alternatives. Both rank acceptability index and the confidence factor is low, we unlikely think about this alternative is the most preferred one. Vice versa, the confidence factor is higher namely over $95 \%$ points to suitable preferences and the decision maker almost surely preferred this alternative [28]. 


\section{The SMAA-MOORA}

The integrated approach SMAA-MOORA for the stochastic MCDM problems consists of 8 steps: 1) Analysis of decision problem; 2) Determining the distributions of the criteria and weight scales; 3) Obtaining criteria measurements of each alternative from criteria distributions; 4) Obtaining weight of criteria from weight scales; 5) Run the MOORA algorithm with criteria measurements and weight which obtained from SMAA-2; 6) For each activity establishing/updating the rankings; 7) Calculating acceptability index, central weight vector and the confidence factor; 8) Making Decision. To compute the SMAA-MOORA we create program code with MATLAB. SMAA-MOORA flow chart is given in figure 1.

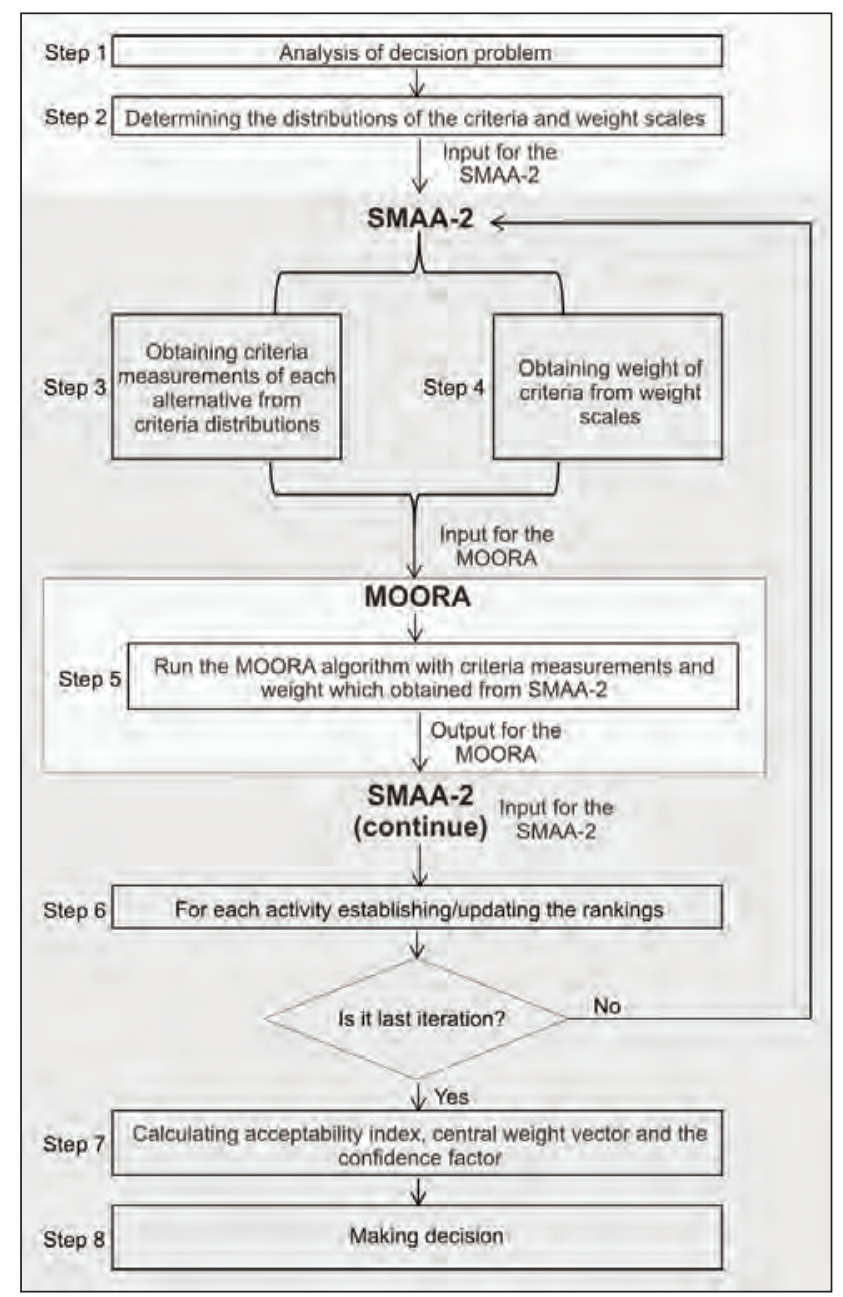

Fig. 1. SMAA-MOORA flow chart

The SMAA-MOORA method uses Monte Carlo simulation calculations to obtain imprecise criteria measurements and weights from their distributions for each simulation iteration. And then running MOORA with these values the relative distances of alternatives to the reference point are obtained. After a suitable number of iterations, acceptability index, the central weight vector and the confidence factor are obtained by analyzing the values in the simulation process. The SMAA-MOORA steps are as follows:
Step 1: Analysis of decision problem

At this step first of all the 11 experts who participate at every stage of decision making are specified from academics and textile industry professionals. These experts determined criteria and alternatives.

Step 2: Determining the distributions of the criteria and weight scales

As in SMAA-2 in SMAA-MOORA both criteria values and weights are defined with density function. This step the density functions are determined.

Step 3 \& Step 4: Obtaining criteria measurements of each alternative from criteria distributions and weight of criteria from weight scales

The parameters are obtained with determined distribution in previous step. In this paper models were solved with normal distribution. This step outputs are the input of MOORA.

Step 5: Run the MOORA algorithm with criteria measurements and weight which obtained from SMAA-2 To obtain deterministic input of MOORA from density functions; Monte Carlo simulation is used to calculate integrals. In each iteration MOORA is run with criteria weights and values are obtained from their distributions. The output of MOORA is replaced with SMAA-2 utility function and used in Step 6.

Step 6: For each activity establishing/updating the rankings

According to the results of MOORA the ranking of the alternatives are established.

Step 7: Calculating Acceptability index, central weight vector and the confidence factor

After enough iteration to acceptability index, central weight vector and the confidence factor are calculated.

Step 8: Making Decision

Initially, a total of 11 experts who participated at every stage of decision making were identified from academics and textile industry professionals. These experts determined 7 criteria for determination of the optimum MVS machine parameter with respect to literature and field work. The hierarchical decision tree with alternatives and criteria is given in figure 2. After all this the alternatives are evaluated by SMAAA and SMAA-MOORA according to their acceptability index. The higher acceptability index means the better alternative.

Two benefit criteria $\left(\boldsymbol{g}_{\mathbf{1}}\right.$ and $\left.\boldsymbol{g}_{\mathbf{2}}\right)$ and five cost criteria $\left(g_{3}, g_{4}, g_{5}, g_{6}\right.$ and $\left.g_{7}\right)$ for the optimization are as follows:

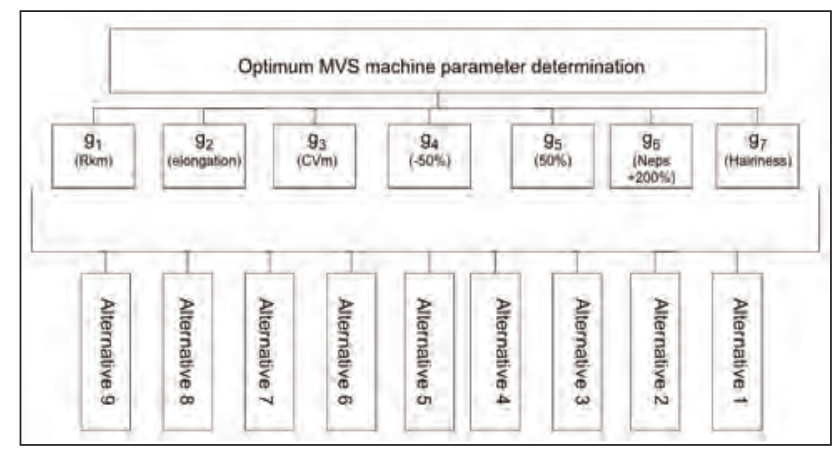

Fig. 2. The hierarchical decision tree 
$\boldsymbol{g}_{1}(\mathbf{R} \mathbf{k m})$ : Rupture per kilometer (RKM) is an important yarn quality parameter and generally is desired higher value of RKM for better yarn quality by fabric producer [29].

$g_{2}$ (Elongation): Yarn elongation is stretching of yarn before the occurrence of yarn breakage and it is related with knit-ability of yarn.

$g_{3}(C V m)$ : Unevenness $(\% \mathrm{CVm})$ is a variation in yarn and leads to unwanted pattern in fabrics.

$g_{4}(-50 \%)$ and $g_{5}(50 \%)$ : The higher value of $\mathrm{CV} \%$, the worse is the measured value of the yarn. Thin places $(-50 \%)$ and thick places $(+50 \%)$ which are number of places that have mass reductions/ increases of $50 \%$ or more with respect to the mean value.

$g_{6}$ (Neps(+200\%)): The numbers of thin and thick places have a significant impact on yarn quality. Neps $(+200 \%)$ level in the yarn is an important quality specification and high level of neps in the yarns lead to poor quality yarn and textile structure appearance $[30,31]$.

$g_{7}$ (Hairiness): Yarn hairiness refers to fibers outgoing from the master body of the yarn. High yarn hairiness can have a negative impact on yarn bending flexural rigidity [31].

By focusing on variation of "nozzle pressure" and "delivery speed" parameters, nine different alternatives are determined listed in table 1 to find the most suitable candidate.

The obtained measurements for these criteria were modeled by normal distribution. The criteria measurements are obtained, without any preference information, from ten different bobbin results. The determined alternatives' criteria measurements are listed in table 2:

And also criteria measurements he alternative preference information occurred from the criteria measurements. To perform the SMAA and SMAAMOORA method 10,000 Monte Carlo iterations are used.

\section{RESULTS AND DISCUSSION}

A yarn must have a certain performance value for manufacturing. The performance of warp or weft knitting machine mainly depends on rupture per

\begin{tabular}{|c|c|c|}
\hline Alternative & $\begin{array}{c}\text { Nozzle pressure } \\
{\left[\mathbf{k g f} / \mathbf{c m}^{2}\right]}\end{array}$ & $\begin{array}{c}\text { Delivery speed } \\
{[\mathbf{m} / \mathbf{m i n}]}\end{array}$ \\
\hline $\mathbf{1}$ & 4 & 300 \\
\hline $\mathbf{2}$ & 4 & 350 \\
\hline $\mathbf{3}$ & 4 & 400 \\
\hline $\mathbf{4}$ & 5 & 300 \\
\hline $\mathbf{5}$ & 5 & 350 \\
\hline $\mathbf{6}$ & 5 & 400 \\
\hline $\mathbf{7}$ & 6 & 300 \\
\hline $\mathbf{8}$ & 6 & 350 \\
\hline $\mathbf{9}$ & 6 & 400 \\
\hline
\end{tabular}

kilometer (RKM) and elongation value of yarn. In addition, yarn imperfections and unevenness are also important properties. Yarn imperfections are known as yarn faults (thin places, thick places and neps) which are determinative a surface of products. Unevenness $(\% \mathrm{CVm})$ is a variation in yarn and leads to unwanted pattern in fabrics [32].

\section{Performing of SMAA-MOORA}

The criteria measurements which are consist of mean and standard deviation were obtained by normal distribution shown in table 2. By applying them, the outputs obtained from SMAA and SMAA-MOORA analysis are rank acceptability indices and confidence factors and they are presented in table 3 , central weight vectors are demonstrated in table 4 . The MOORA results acquired by using the average values in the table 2 and assuming equal criteria weights. The MOORA and SMAA-MOORA results have close rank and are shown in the table 5.

By looking at the SMAA-MOORA results $A_{2}$ being preferred with $\% 72.5$ the highest rank acceptability index for first rank. And it is observed that $A_{2}$ get $\% 98.5$ confidence factor which is quite enough confident to make decision. Regarding the central weight vectors, it is observed that, criteria have close weights over the rank of alternative $A_{2}$ in the first place. The MOORA results gave same result with assumption of weight criteria are indistinguishable from each other. Both SMAA-MOORA and MOORA

Table 2

\begin{tabular}{|c|c|c|c|c|c|c|c|}
\hline & $\mathbf{g}_{\mathbf{1}}$ & $\mathbf{g}_{\mathbf{2}}$ & $\mathbf{g}_{\mathbf{3}}$ & $\mathbf{g}_{\mathbf{4}}$ & $\mathbf{g}_{\mathbf{5}}$ & $\mathbf{g}_{\mathbf{6}}$ & $\mathbf{g}_{\mathbf{7}}$ \\
\hline $\mathbf{A}_{\mathbf{1}}$ & $13,6 \pm 1,08$ & $5,57 \pm 0,43$ & $16,46 \pm 0,39$ & $73,8 \pm 25$ & $190,3 \pm 43$ & $335,3 \pm 58$ & $4,19 \pm 0,09$ \\
\hline $\mathbf{A}_{\mathbf{2}}$ & $12,71 \pm 1,12$ & $5,31 \pm 0,4$ & $15,14 \pm 0,32$ & $24,3 \pm 10,4$ & $135,5 \pm 34,5$ & $169 \pm 29,4$ & $4,41 \pm 0,1$ \\
\hline $\mathbf{A}_{\mathbf{3}}$ & $11,45 \pm 1,001$ & $4,6 \pm 0,379$ & $17,17 \pm 0,34$ & $114,3 \pm 19$ & $291,5 \pm 40$ & $211,8 \pm 37$ & $5,7 \pm 0,17$ \\
\hline $\mathbf{A}_{\mathbf{4}}$ & $13,48 \pm 1,1$ & $6,19 \pm 0,53$ & $16,9 \pm 0,42$ & $104,5 \pm 35$ & $223 \pm 45$ & $433,5 \pm 65$ & $3,97 \pm 0,05$ \\
\hline $\mathbf{A}_{\mathbf{5}}$ & $13,32 \pm 1,07$ & $5,39 \pm 0,36$ & $17,37 \pm 0,4$ & $113,3 \pm 26$ & $290,3 \pm 61$ & $470,8 \pm 155$ & $4,39 \pm 0,16$ \\
\hline $\mathbf{A}_{\mathbf{6}}$ & $12,45 \pm 1,13$ & $5,26 \pm 0,36$ & $16,53 \pm 0,27$ & $75,5 \pm 16$ & $231,3 \pm 36$ & $183 \pm 30$ & $5,31 \pm 0,21$ \\
\hline $\mathbf{A}_{\mathbf{7}}$ & $13,3 \pm 1,26$ & $6,09 \pm 0,49$ & $17,22 \pm 0,38$ & $127,3 \pm 40$ & $246,3 \pm 48$ & $539,3 \pm 75$ & $3,93 \pm 0,05$ \\
\hline $\mathbf{A}_{\mathbf{8}}$ & $13,55 \pm 1,18$ & $5,63 \pm 0,48$ & $17,8 \pm 0,3$ & $148 \pm 30$ & $316,3 \pm 41$ & $574,5 \pm 89$ & $4,26 \pm 0,1$ \\
\hline $\mathbf{A}_{\mathbf{9}}$ & $12,79 \pm 1,09$ & $5,42 \pm 0,46$ & $17,05 \pm 0,27$ & $98,3 \pm 26$ & $300,5 \pm 58$ & $304,8 \pm 54$ & $4,66 \pm 0,1$ \\
\hline
\end{tabular}




\begin{tabular}{|c|c|c|c|c|c|c|c|c|c|c|}
\hline & Conf. fac. & $r^{1}$ & $r^{2}$ & $r^{3}$ & $r^{4}$ & $r^{5}$ & $r^{6}$ & $\mathbf{r}^{7}$ & $r^{8}$ & $r^{9}$ \\
\hline \multicolumn{11}{|c|}{ SMAA } \\
\hline$A_{1}$ & 0,192 & 0,197 & 0,177 & 0,161 & 0,131 & 0,111 & 0,095 & 0,066 & 0,044 & 0,019 \\
\hline$A_{2}$ & 0,051 & 0,051 & 0,074 & 0,096 & 0,11 & 0,123 & 0,144 & 0,153 & 0,148 & 0,103 \\
\hline$A_{3}$ & 0,002 & 0,002 & 0,007 & 0,01 & 0,025 & 0,042 & 0,069 & 0,123 & 0,225 & 0,496 \\
\hline$A_{4}$ & 0,172 & 0,168 & 0,163 & 0,146 & 0,136 & 0,12 & 0,105 & 0,079 & 0,056 & 0,027 \\
\hline$A_{5}$ & 0,13 & 0,132 & 0,144 & 0,144 & 0,138 & 0,126 & 0,119 & 0,093 & 0,07 & 0,035 \\
\hline$A_{6}$ & 0,038 & 0,035 & 0,057 & 0,077 & 0,094 & 0,116 & 0,126 & 0,166 & 0,178 & 0,152 \\
\hline$A_{7}$ & 0,161 & 0,156 & 0,136 & 0,128 & 0,124 & 0,116 & 0,104 & 0,099 & 0,087 & 0,051 \\
\hline$\underline{\mathbf{A}_{8}}$ & $\underline{0,197}$ & $\underline{0,199}$ & 0,162 & 0,133 & 0,129 & 0,114 & 0,096 & 0,081 & 0,055 & 0,031 \\
\hline$A_{9}$ & 0,055 & 0,061 & 0,081 & 0,104 & 0,114 & 0,133 & 0,143 & 0,141 & 0,137 & 0,087 \\
\hline \multicolumn{11}{|c|}{ SMAA-MOORA } \\
\hline$A_{1}$ & 0,256 & 0,127 & 0,299 & 0,205 & 0,151 & 0,121 & 0,065 & 0,022 & 0,008 & 0,003 \\
\hline$\underline{\mathbf{A}_{2}}$ & $\underline{0,985}$ & $\underline{0,725}$ & 0,13 & 0,051 & 0,029 & 0,021 & 0,016 & 0,013 & 0,009 & 0,006 \\
\hline$A_{3}$ & 0,032 & 0,002 & 0,023 & 0,103 & 0,118 & 0,153 & 0,166 & 0,165 & 0,14 & 0,131 \\
\hline$A_{4}$ & 0,224 & 0,048 & 0,095 & 0,124 & 0,143 & 0,143 & 0,185 & 0,144 & 0,08 & 0,038 \\
\hline$A_{5}$ & 0,015 & 0,01 & 0,034 & 0,066 & 0,1 & 0,131 & 0,164 & 0,188 & 0,16 & 0,147 \\
\hline$A_{6}$ & 0,253 & 0,051 & 0,295 & 0,244 & 0,164 & 0,093 & 0,058 & 0,036 & 0,045 & 0,013 \\
\hline$A_{7}$ & 0,075 & 0,014 & 0,039 & 0,06 & 0,088 & 0,106 & 0,119 & 0,167 & 0,218 & 0,192 \\
\hline$A_{8}$ & 0,062 & 0,001 & 0,007 & 0,013 & 0,024 & 0,048 & 0,086 & 0,152 & 0,263 & 0,407 \\
\hline$A_{9}$ & 0,105 & 0,023 & 0,078 & 0,134 & 0,184 & 0,184 & 0,142 & 0,114 & 0,077 & 0,064 \\
\hline
\end{tabular}

Table 4

\begin{tabular}{|c|c|c|c|c|c|c|c|}
\hline & $g_{1}$ & $g_{2}$ & $g_{3}$ & $g_{4}$ & $g_{5}$ & $g_{6}$ & $g_{7}$ \\
\hline \multicolumn{8}{|c|}{ SMAA } \\
\hline$A_{1}$ & 0,145 & 0,142 & 0,14 & 0,143 & 0,143 & 0,141 & 0,146 \\
\hline$A_{2}$ & 0,144 & 0,137 & 0,151 & 0,14 & 0,142 & 0,147 & 0,14 \\
\hline$A_{3}$ & 0,127 & 0,14 & 0,157 & 0,164 & 0,173 & 0,11 & 0,13 \\
\hline$A_{4}$ & 0,146 & 0,147 & 0,135 & 0,146 & 0,146 & 0,142 & 0,138 \\
\hline$A_{5}$ & 0,146 & 0,146 & 0,141 & 0,145 & 0,143 & 0,143 & 0,138 \\
\hline$A_{6}$ & 0,155 & 0,148 & 0,129 & 0,151 & 0,141 & 0,132 & 0,144 \\
\hline$A_{7}$ & 0,141 & 0,143 & 0,144 & 0,142 & 0,144 & 0,137 & 0,149 \\
\hline$\underline{A}_{8}$ & $\underline{0,14}$ & $\underline{0,149}$ & $\underline{0,142}$ & $\underline{0,144}$ & $\underline{0,144}$ & $\underline{0,138}$ & $\underline{0,144}$ \\
\hline$A_{9}$ & 0,15 & 0,142 & 0,147 & 0,148 & 0,128 & 0,141 & 0,144 \\
\hline \multicolumn{8}{|c|}{ SMAA-MOORA } \\
\hline$A_{1}$ & 0,197 & 0,18 & 0,135 & 0,099 & 0,136 & 0,074 & 0,179 \\
\hline$\underline{\mathbf{A}_{2}}$ & $\underline{0.124}$ & $\underline{0.121}$ & $\underline{0.144}$ & $\underline{0,166}$ & $\underline{0.154}$ & $\underline{0.154}$ & $\underline{0.137}$ \\
\hline$A_{3}$ & 0,242 & 0,095 & 0,138 & 0,052 & 0,083 & 0,316 & 0,074 \\
\hline$A_{4}$ & 0,18 & 0,273 & 0,127 & 0,072 & 0,11 & 0,05 & 0,188 \\
\hline$A_{5}$ & 0,227 & 0,182 & 0,129 & 0,069 & 0,08 & 0,133 & 0,182 \\
\hline$A_{6}$ & 0,188 & 0,191 & 0,139 & 0,085 & 0,093 & 0,219 & 0,085 \\
\hline$A_{7}$ & 0,217 & 0,26 & 0,129 & 0,069 & 0,106 & 0,034 & 0,185 \\
\hline$A_{8}$ & 0,397 & 0,236 & 0,07 & 0,047 & 0,041 & 0,027 & 0,182 \\
\hline$A_{9}$ & 0,216 & 0,265 & 0,125 & 0,08 & 0,064 & 0,133 & 0,118 \\
\hline
\end{tabular}

Table 5

\begin{tabular}{|c|c|c|c|c|c|c|c|c|}
\hline$\underline{\mathbf{A 2}}$ & $\mathbf{A 1}$ & $\mathbf{A 6}$ & $\mathbf{A 9}$ & $\mathbf{A 4}$ & $\mathbf{A 5}$ & A3 & A7 & A8 \\
\hline$\underline{0,053}$ & 0,159 & 0,165 & 0,238 & 0,258 & 0,287 & 0,290 & 0,331 & 0,399 \\
\hline
\end{tabular}


select $A_{2}$ in the first place. But the SMAA establish the $A_{8} \% 19.9$ the highest rank acceptability index for the first rank with \%19.7 confidence factor which measures whether the criteria measurements are accurate enough to discern the efficient alternatives. While the results of the three methods are examined SMAA-MOORA has more accurate than SMAA by means of higher confidence factor. Besides MOORA results supports SMAA-MOORA results accuracy. In the determination of the optimum MVS machine parameterby integration of SMAA and SMAAMOORA, the inverse approach is used instead of asking preferences. This feature is the particular and characteristic of SMAA methods. The central weight vector shows the preferences of a typical DM supporting this alternative with the assumed preference model. For each preference model there are different central weight vector. As displayed in table 4 there are 9 different central weight vectors. Among the SMAA's central weight vectors $A_{8}$ 's central weight vector shows preferences which support the alterna-

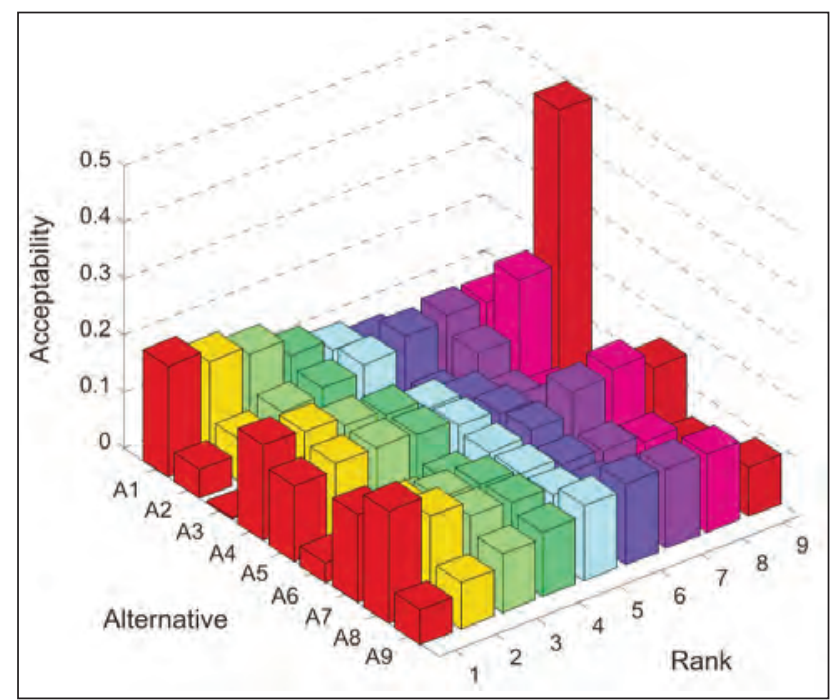

Fig. 3. Rank acceptability index of SMAA

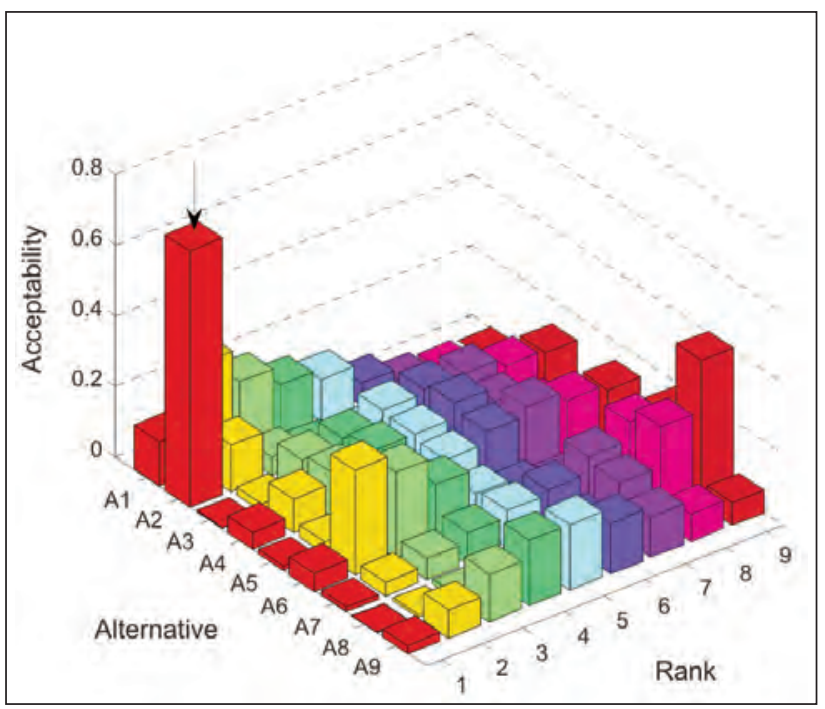

Fig. 4. Rank acceptability index of SMAA-MOORA tive $A_{8}$ to the most suitable one. And the $A_{2}$ 'scentral weight vector shows preferences for the best alternative $A_{2}$ within SMAA-MOORA central weight vectors. For SMAA-MOORA results according to the central weight vector of $A_{2} g_{4}$ - $50 \%$ " has the highest importance with the highest weight value of 0.166 and $\mathrm{g}_{2}$-"Elongation" has the least importance with the lowest weight value of 0.121 . For SMAA results in the central weight vector of $A_{8}$, the criteria have close importance to each other near 0.14.

In the optimizing MVS parameter in Ne 30 production with stochastic data, decision making process using SMAA-MOORA could be successfully applied to find out the best proper parameter alternative. Consequently, the results of this study revealed that the most optimum parameter variation to be managed primarily in textile production can be determined based on manufacturing process line, variety of target products and production capacity.

The rank acceptabilities of SMAA and SMAAMOORA and rank of MOORA are also displayed in figures 3-5. When we compare confidence factors of stochastic MCDM methods SMAA and SMAAMOORA the SMAA-MOORA confidence factor $\% \mathbf{0 , 9 8 5}$ is way ahead from SMAA confidence factor $\% 0,197$. And alsothe alternative $A_{2}$ has first place both SMAA-MOORA and MOORA. Unlike them SMAA determines $A_{8}$ is the best alternative. So we can make inferences from these results the validity of the new method SMAA-MOORA.

The criteria values highly vary because values are received from ten different. Moreover a bobbin varies in itself. This variability causes the difference in results between these two methods SMAA and SMAA-MOORA. And also results demonstrate that SMAA-MOORA, integration of deterministic MCDM method MOORA with SMAA, can handle variability better than SMAA.

All confidence factor values are given in table 6 to more clearly compare the effectiveness of the methods. The alternative with the highest confidence value is chosen as the best alternative. Besides, 11 experts who are specified from academics and textile

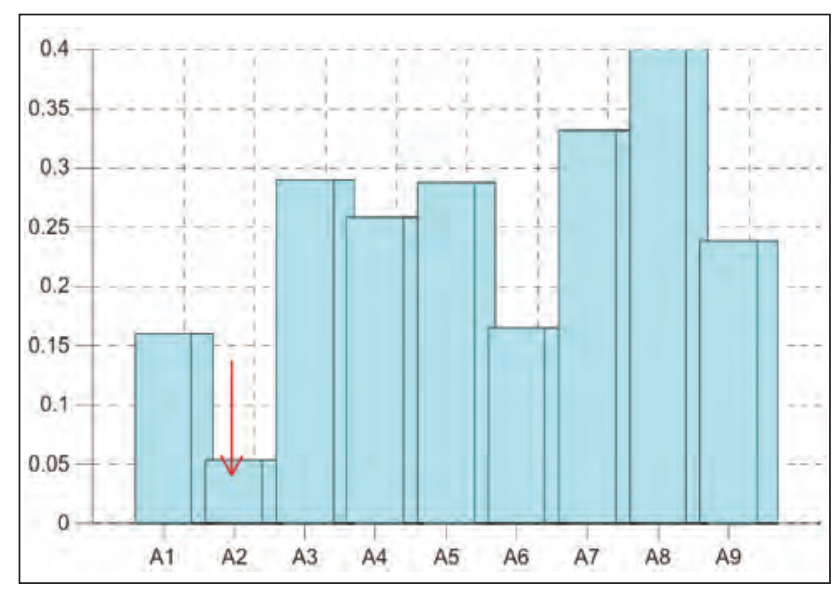

Fig. 5. The MOORA results 


\begin{tabular}{|c|c|c|}
\hline \multicolumn{3}{|c|}{ Confidence factor } \\
\hline Mlternative & SMAA & SMAA-MOORA \\
\hline $\mathbf{A}_{\mathbf{1}}$ & 0,192 & 0,256 \\
\hline $\mathbf{A}_{\mathbf{2}}$ & 0,051 & $\underline{\mathbf{0 , 9 8 5}}$ \\
\hline $\mathbf{A}_{\mathbf{3}}$ & 0,002 & 0,032 \\
\hline $\mathbf{A}_{\mathbf{4}}$ & 0,172 & 0,224 \\
\hline $\mathbf{A}_{\mathbf{5}}$ & 0,13 & 0,015 \\
\hline $\mathbf{A}_{\mathbf{6}}$ & 0,038 & 0,253 \\
\hline $\mathbf{A}_{\mathbf{7}}$ & 0,161 & 0,075 \\
\hline $\mathbf{A}_{\mathbf{8}}$ & $\underline{\mathbf{0 , 1 9 7}}$ & 0,062 \\
\hline $\mathbf{A}_{\mathbf{9}}$ & 0,055 & 0,105 \\
\hline
\end{tabular}

industry professionals gathered and evaluated the results obtained by the methods. They conclude that SMAA-MOORA is better than or be comparable with the SMAA, in terms of confidence factor values. Moreover, they chose $A_{2}$ as the best alternative, in accordance with SMAA-MOORA results.
The SMAA-MOORA method is integration of SMAA-2 and MOORA method, and SMAA-MOORA uses MOORA instead of SMAA-2 utility function. The SMAA-2 method uses stochastic data and calculates randomly criteria weight with Monte Carlo simulation. This new method has both SMAA-2 and MOORA advantagesthat a popular, consistent and easily applicable MCDM method.

Thanks to the new method SMAA-2 outputs are more consistent and MOORA can use with stochastic data. The confidence factors show that SMAA-MOORA is more confident than SMAA-2.

In this study we have proposed SMAA-MOORA method and applied this method MVS yarn machine parameter optimization. Nine different yarn samples were spun by considering of two parameters in MVS system which are nozzle pressure and delivery speed with three different levels. According to results of SMAA-MOORA method, Ne 30 cotton yarn sample spun when delivery speed is $350 \mathrm{~m} / \mathrm{min}$ and nozzle pressure is $4 \mathrm{kgf} / \mathrm{cm}^{2}$ has the best performance among possible alternatives.

\section{BIBLIOGRAPHY}

[1] Oxenham, W. Fasciated yarns - a revolutionary development? In: Journal Textile Apparel Technology Management, 2001, vol. 1, no. 2, pp. 1-7.

[2] Ortlek, H.G., Ulku, Ş. Effect of spandex and yarn counts on the properties of elastic core-spun yarns produced on Murata Vortex Spinner, In: Textile Research Journal, June 2007, vol. 77, pp. 432-436.

[3] Erdumlu, N., Ozipek, B., Oztuna, A.S., Cetinkaya, S. Investigation of vortex spun yarn properties in comparison with conventional ring and open-end rotor spun yarns, In: Textile Research Journal, May 2009, vol. 79, pp. 585-595.

[4] Pei, Z., Yu, C. Numerical and experimental research on the influence of parameters on the tensile properties of Murata Vortex Yarn, In: The Journal of The Textile Institute, 2010, vol. 101, no. 10, pp. 931-940.

[5] Basal, G., Oxenham, W. Effects of some process parameters on the structure and properties of vortex spun yarn. In: Textile Research Journal, 2006, vol. 76, no. 6, pp. 492-499.

[6] Ortlek, H.G., Ulku, S. Effect of some variables on properties of $100 \%$ cotton vortex spun yarn. In: Textile Research Journal, 2005, vol. 75, no. 6, pp. 458-461.

[7] Tyagi, G.K., Sharma, D. Performance and low-stress characteristics of polyester-cotton MVS yarns. Indian Journal of Fibre\&Textile Research, 2004, vol. 29, pp. 301-307.

[8] Karakan Günaydin, G., Erdem, R., Palamutçu, S., Abdulla, G. The influence of nozzle pressure and yarn count on vortex spun yarn properties produced by MVS Machine, In: Industria Textila, 2015, vol. 66, no. 1, pp. 11-18.

[9] Majumdar, A., Sarkar, B., Majumdar, P. A new algorithm of cotton fiber selection and lay-down using TOPSIS method of multi-criteria decision making, In: Indian Journal of Fibers \& Textile Research, 2006, vol. 31, pp. 248-255.

[10] Valipour, P., Moghassem, A.R. Employment of PROMETHEE approach for selecting suitable yarn for weft knitting process considering drawing frame varibles, In: Fibres and Polymers, 2014, vol. 15, no. 4, 865-873.

[11] Płonka, S., Ogiński, L. Multicriterial optimisation of the manufacturing process of a spindle working in a ring spinning frame, In: Fibres \& Textiles in Eastern Europe, (2014), 22, 6(108), pp. 51-58.

[12] Majumdar, A., Kaplan, S., Goktepe, O. Navel selection for rotor spinning denim fabrics using a multi-criteria decision making process, In: The Journal of the Textile Industry, April 2010, vol. 101, no. 4, pp. 294-308.

[13] Kaplan, S., Araz, C., Goktepe, O. A multi-criteria decision aid approach on novel selection problem for rotor spinning, In: Textile Research Journal, 2006, vol. 76, no. 12, pp. 896-904.

[14] Moghassem, A.R., Bahramzadeh, H. Application of multi-criteria analysis for parameters selection problem in rotor spinning machine, In: Textile Research Journal, 2010, vol. 80, no. 20, pp. 2176-2187.

[15] Moghassem, A.R. Comparison among two analytical methods of multi-criteria decision making for appropriate spinning condition selection, In: World Applied Sciences Journal, 2013, vol. 21, no. 5, pp. 784-794.

[16] Yukseloglu, S.M., Yayla, A., Yildiz, K. Yarn selection for weaving process to determine the parameters in OE rotor, In: Industria Textila, 2015, vol. 66, no. 1, pp. 3-10. 
[17] Tervonen, T., Figueira, J.R., Lahdelma, R., Dias, J.A., Salminen, P.A. Stochastic method for robustness analysis in sorting problems, In: European Journal of Operational Research, 2009, vol. 192, no. 1, pp. $236-242$.

[18] Hokkanen, J., Lahdelma, R., Miettinen, K., Salminen, P. Determining the implementation order of a general plan by using a multicriteria method, In: Journal of Multi-Criteria Decision Analysis, 1998, vol. 7, no. 5, pp. $273-284$.

[19] Corrente, Salvatore, José Rui Figueira, Salvatore Greco. The smaa-promethee method. In: European Journal of Operational Research, 2014, vol. 239, no. 2, pp. 514-522.

[20] Okul, D., Gencer, C., Aydogan, E.K. A method based on SMAA-topsis for stochastic multi-criteria decision making and a real-world application. In: International Journal of Information Technology \& Decision Making, 2014, vol. 13, no. 05, pp. 957-978.

[21] Kizilkaya Aydogan, E., Ozmen, M. (2015).Two new method for multi criteria stochastic decision making: SMAA-GRA and SMAA-DEMATEL-GRA, In: Journal of the Faculty of Engineering and Architecture of Gazi University, 30(4), pp. 627-640.

[22] Aydogan, E.K., Ozmen, M. (2017). The stochastıc vikor method and its use in reverse logistic option selection problem. In: RAIRO-Operations Research, 51(2), pp. 375-389.

[23] Brauers, Willem Karel M., Edmundas Kazimieras Zavadskas. The MOORA method and its application to privatization in a transition economy, In: Control and Cybernetics, 2006, vol. 35, no. 2, p. 445.

[24] Chakraborty, Shankar. Applications of the MOORA method for decision making in manufacturing environment, In: The International Journal of Advanced Manufacturing Technology, 2011,vol. 54, no. 9-12, pp. 1155-1166.

[25] Lahdelma, R., Hokkanen, J., Salminen, P. SMAA-Stochastic multiobjective acceptability analysis, In: European Journal of Operational Research, 1998, vol. 106, pp. 137-143.

[26] Tervonen, T., Figueira, J.R. A survey on stochastic multicriteria acceptability analysis methods, In: Journal of Multi-Criteria Decision Analysis, 2008, vol. 15, pp. 1-14.

[27] Lahdelma, R., Salminen, P. SMAA-2: stochastic multicriteria acceptability analysis for group decision making. In: Operations Research, 2001, vol. 49, no. 3, pp. 444-454.

[28] Kangas, A.S., Kangas, J., Lahdelma, R., Salminen, P. Using SMAA-2 method with dependent uncertainties for strategic forest planning, In: Forest policy and economics, 2006, vol. 9, no. 2, pp. 113-125.

[29] Kotb N.A. Predicting yarn quality performance based on fibers types and yarn structure, In: Life Science Journal, 2012, vol. 9, no. 3, pp. 1009-1015.

[30] Helal, A., Al-Betar, E.M., El-Gamal M., Hasan Ghada, A. Effects of wool fiber diameter and bulk on fabric bursting strength. In: Journalof American Science, 2014, vol. 10, no. 7, pp. 14-18.

[31] http://www.muratec-vortex.com. Accessed: 24/01/2015.

[32] Candan, C., Nergis, U.B., Iridag,Y. Performance of open-end and ring spun yarns in weft knitted fabrics, In: Textile Research Journal, 2000, vol. 70, pp. 177-181.

[33] Seema, K., Kumar, D. Designing a mathematical model using fuzzy based MOORA method for supplier selection, In: International Journal of Advanced Engineering Technology, 2014, pp. 16-24.

\section{Authors:}

\section{ESRA AKGUL ${ }^{1}$ \\ MIHRIMAH OZMEN ${ }^{2}$ \\ EMEL KIZILKAYA AYDOĞAN² \\ HUSEYIN GAZI TURKSOY ${ }^{3}$}

${ }^{1}$ Department of Industrial Design Engineering, Erciyes University, Kayseri, Turkey

${ }^{2}$ Department of Industry Engineering, Erciyes University, Kayseri, Turkey

${ }^{3}$ Department of Textile Engineering, Erciyes University, Kayseri, Turkey

e-mail: akgul@erciyes.edu.tr, mihrimah@erciyes.edu.tr, ekaydogan@erciyes.edu.tr, hgazi@erciyes.edu.tr

Corresponding author:

HUSEYIN GAZI TURKSOY

hgazi@erciyes.edu.tr 


\title{
Knitted agrotextiles for a sustainable agriculture
}

\author{
DOI: 10.35530/IT.068.05.1413
}

\section{REZUMAT - ABSTRACT}

\section{Agrotextile tricotate pentru o agricultură sustenabilă}

În această lucrare sunt prezentate primele rezultate în scopul realizării unor variante de plase agrotextile pentru diverse destinații în domeniul agriculturii/horticulturii. În acest scop, au fost folosite fire din poliester şi poliamidă pentru a produce plase tricotate pe mașini de tricotat urzeală. Tehnologia de tricotat din urzeală oferă o gamă largă de posibilități de producere a plaselor, pe care nicio altă tehnologie nu le poate oferi. Alături de țeserea și tricotarea din bătătură, tricotarea din urzeală este utilizată pe scară largă pentru a produce substraturi textile pentru o mare varietate de aplicații. Variantele obținute au fost testate în laboratoarele acreditate ale INCDTP. Caracteristicile plaselor tricotate trebuie să fie corelate cu destinația lor, precum și cu parametrii funcționali și de proiectare.

Cuvinte-cheie: textile tehnice, plase tricotate, tricotare din urzeală, agricultură, horticultură

\section{Knitted agrotextiles for a sustainable agriculture}

In this paper there are presented the first results to develop some variants of agrotextile nets for various destinations in agriculture/horticulture fields. For this purpose, polyester and polyamide yarns were used to produce knitted nets on warp knitting machines. Warp knitting technology offers a wide range of possibilities for producing nets, which no other technology can match. Alongside weaving and weft knitting, warp knitting is widely used to produce textile substrates for a variety of applications. The obtained variants were tested in the accredited laboratories of the INCDTP. The characteristics of the knitted nets need to be correlated to their destination as well as the functional and design parameters.

Keywords: technical textiles, knitted nets, warp knitting, agriculture, horticulture

\section{INTRODUCTION}

Agriculture has been among the most primal occupations of the humankind and is still a major industry, globally. In this era of modernization and high technological advancements, it has spread its horizons and started using man-made, non-conventional textiles, called "technical textiles". These are materials and products manufactured primarily for their technical and performance properties rather than for their aesthetic or decorative characteristics.

Agrotextiles are the textile materials used in agriculture, horticulture, floriculture etc. and are part of technical textiles. By achieved performances, agrotextiles represent an opportunity for farmers to successfully manage with the challenges in both natural conditions and agricultural market demands.

This textile sector comprises all textiles that are used in growing, harvesting, protection and storage of either crops or animals. It includes diverse items such as fishing nets and fish-lines, ropes, shade fabrics, mulch mats, woven and non-woven covers for crops, bird protection nests etc. The agrotextiles are used for their functional benefits in the agricultural field and are driving the sector profitably by improving the productivity and reducing the need for chemicals. Some of the purposes for which these textiles are being increasingly used are as follows: preventing erosion and paving way for afforestation; in greenhouse cover and fishing nets; for layer separation in fields; in nets for plants, rootless plants \& protecting grassy areas; as sun screens (since they have adjustable screening) and wind shields; as packing material and in bags for storing grass (that has been mowed); controlling stretch in knitted nets; shade for basins; antibirds nets; fabrics for sifting and separation, for the phases of enlargement of the larvae; materials for ground and plant water management at the time of scarcity and abundance of water [1].

In the present era of globalisation, the importance of agriculture as a prime mover particularly in developing countries has become unequivocal.

Every nation is interested in the ability to improve the quantity and quality of food production to feed the population and to have a substantial reserve. This objective can be reached through factors that influence plant growth, together with the application of improved techniques and the use of textiles in agriculture is the most important [1].

As in many cases agriculture is the backbone of economy, the textile industry can be the backbone of agriculture.

The majority of agrotextiles are knitted textile materials, due to the wider fields of application, by comparison to woven and unconventional fabrics products. These structures are, mostly, made on a warp knitting machines. They present numerous advantages [2]:

- do not affect in any way the crops or the soil and ensure the permeability of ecological environment; 
- nets do not overshadow crops or fruit trees and do not affect their growth;

- prove very good ventilation, which leads to low moisture conditions;

- have good air, water and light transmission;

- very good mechanical resistance and high flexibility;

- light weight, can be placed on simple support structure or directly on crops or trees in some situations;

- are wind, water, UV emissions and weather proof;

- are not toxic to birds, do not harm them;

- are resistant to mildew and decay;

- can be reused several seasons, up to 10 years;

- their use means less chemical treatments applied to crops, leading to lower costs and improving consumer perception;

- the waste of agriculture products are eliminate/ diminished due to the protective properties of crops against weather and pests.

The most important physico-mechanical and functional properties of agrotextiles are: tensile strength; weight; UV resistance; resistance at insects, microorganisms, humidity; shading factor; air permeability and porosity; biodegradability.

The main types of agrotextiles are:

- shade nets;

- anti-hail nets;

- anti-insect nets and pollination nets;

- windshield nets;

- bird and animal protection nets;

- harvesting nets;

- crop covers/anti-frost covers.

Figure 1 shows the basic characteristics of agrotextiles correlated to their destination as well as the functional and design parameters [3].

\section{MATERIALS AND METHODS}

The aim of the research is to develop agrotextile nets for various destinations in agriculture/horticulture fields such as insects protection, pollination, hail protection, etc. Accordingly, in this stage of the research there were developed 5 variants of knitted nets made from 2 types of yarns: polyamide monofilament and polyester. In order to achieve the aim of the research,

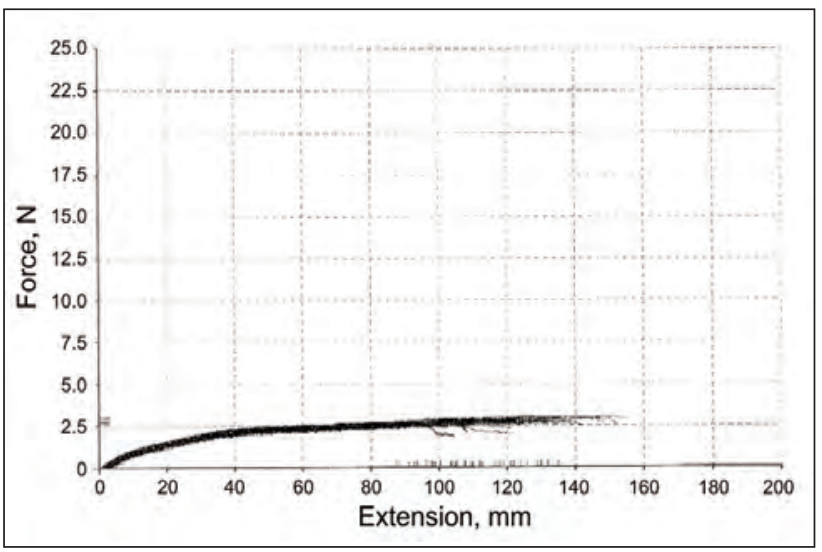

Fig. 2. Stress-strain diagram for polyester yarn

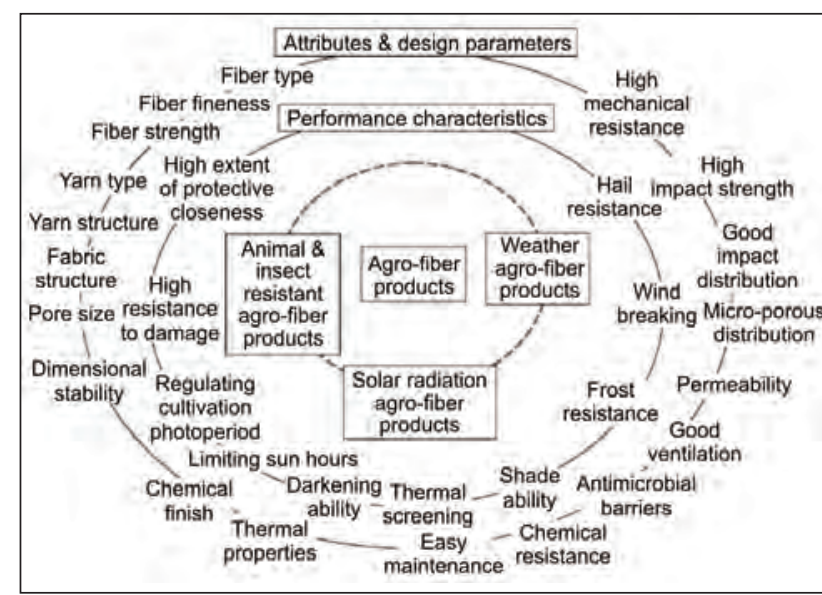

Fig. 1. The basic characteristics of agrotextiles and their functional and design parameters [3]

Table 1

\begin{tabular}{|l|c|c|c|}
\hline \multicolumn{2}{|c|}{ Characteristics } & $\begin{array}{c}\text { Polyamide } \\
\text { monofilament }\end{array}$ & Polyester \\
\hline Linear density & dtex & 129 & 83 \\
\hline Diameter & $\mathrm{mm}$ & 12 & - \\
\hline \multirow{2}{*}{ Breaking force } & $\mathrm{N}$ & 7.20 & 2.82 \\
\cline { 2 - 4 } & $\mathrm{Cv} \%$ & 2.29 & 4.93 \\
\hline $\begin{array}{l}\text { Elongation } \\
\text { at break }\end{array}$ & $\%$ & 32.74 & 22.44 \\
\cline { 2 - 4 } $\begin{array}{l}\text { Thermal } \\
\text { contraction }\end{array}$ & $\mathrm{C} \%$ & 4.25 & 11.62 \\
\hline
\end{tabular}

the present objective is to evaluate the mechanical characteristics of the obtained variants. To confirm that these types of yarns are suitable for the research purpose, experimental studies were conducted in the accredited laboratories of INCDTP Bucharest (table 1). The stress-strain diagrams for the two types of yarns are shown in figure 2 and 3.

The obtained data for the analyzed characteristics of the yarns (breaking force, elongation at break or thermal contraction) match the standard values of the yarns used to produce knitted structures according to the chosen destination (pollination, shading, antiinsects, harvesting).

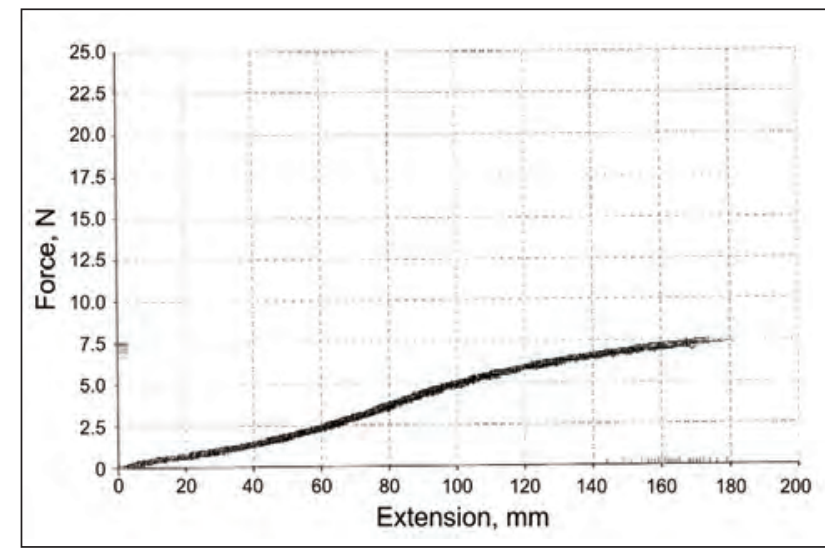

Fig. 3. Stress-strain diagram for polyamide yarn 
In order to produce agrotextile nets for the chosen destination, the knitting operation will be performed on warp knitting machines. Warp knitting technology offers a wide range of possibilities for producing nets, which no other technology can match. Alongside weaving and weft knitting, warp knitting is widely used to produce textile substrates for a variety of applications. Warp knitted fabrics can be elastic or dimensionally stable; they may have open or dense constructions, and may have fine or coarse structures. They can be produced as flat, tubular or threedimensional textiles in widths of up to 6 metres and above. Besides the exceptional width of the nets, another advantage is that the design of the nets can also be varied extensively; depending upon the knitting process used and the construction warp knitting technology enables the individual products to be adapted to suit specific requirements [4].

\section{RESULTS AND DISCUSSIONS}

There were made 5 variants of knitted nets on Karl Mayer knitting machine RJSC 4F-NE E18 at NGM Leonard SRL Pascani. The type of the yarn used and the structure of the knitted variants are presented in the table 2 .

Table 2

\begin{tabular}{|c|c|c|c|}
\hline Variant & Yarn & Structure & Structure image \\
\hline V1 & $\begin{array}{l}\text { Polyester } \\
83 \text { dtex }\end{array}$ & $\begin{array}{l}\text { Pillar stitch } \\
\text { structure with } \\
\text { weft yarn } \\
\text { inserted at } \\
1 \text { row and } \\
2 \text { wales }\end{array}$ & 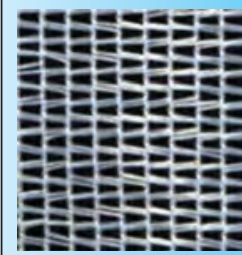 \\
\hline V2 & $\begin{array}{l}\text { Polyester } \\
83 \text { dtex }\end{array}$ & $\begin{array}{l}\text { Pillar stitch } \\
\text { structure with } \\
\text { weft yarn } \\
\text { inserted at } \\
4 \text { rows and } \\
5 \text { wales }\end{array}$ & \\
\hline V3 & $\begin{array}{l}\text { Polyamide } \\
\text { mono- } \\
\text { filament } \\
129 \mathrm{dtex} \\
(0.12 \mathrm{~mm})\end{array}$ & $\begin{array}{l}\text { Pillar stitch } \\
\text { structure with } \\
\text { weft yarn } \\
\text { inserted at } \\
4 \text { rows and } \\
4 \text { wales }\end{array}$ & \\
\hline V3A & $\begin{array}{l}\text { Polyamide } \\
\text { mono- } \\
\text { filament } \\
129 \mathrm{dtex} \\
(0.12 \mathrm{~mm})\end{array}$ & $\begin{array}{l}\text { Pillar stitch } \\
\text { structure with } \\
\text { weft yarn } \\
\text { inserted at } \\
1 \text { row and } \\
2 \text { wales }\end{array}$ & 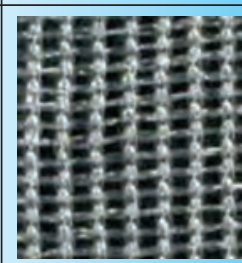 \\
\hline V4 & $\begin{array}{l}\text { Polyamide } \\
\text { mono- } \\
\text { filament } \\
129 \mathrm{dtex} \\
(0.12 \mathrm{~mm})\end{array}$ & $\begin{array}{l}\text { Pillar stitch } \\
\text { structure with } \\
\text { weft yarn } \\
\text { inserted at } \\
3 \text { rows and } \\
4 \text { wales }\end{array}$ & $(1)(1), 1)$ \\
\hline
\end{tabular}

The variants characterization of knitted nets for agriculture/horticulture developed in this phase of the research

The experimental studies of physico-mechanical (weight, breaking force, elongation at break, thermal contraction, resistance at burst and deformation at burst) and structure characteristics (density, mesh size) of knitted nets were also conducted in the accredited laboratories of INCDTP Bucharest (table 3). The stress-strain diagram for all 5 variants is shown in figures 4-13.

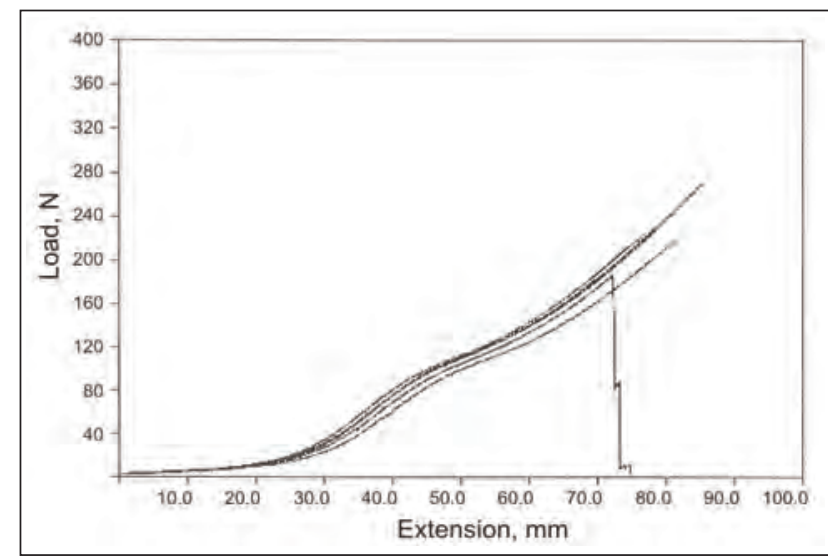

Fig. 4. Stress-strain diagram V1 - horizontal

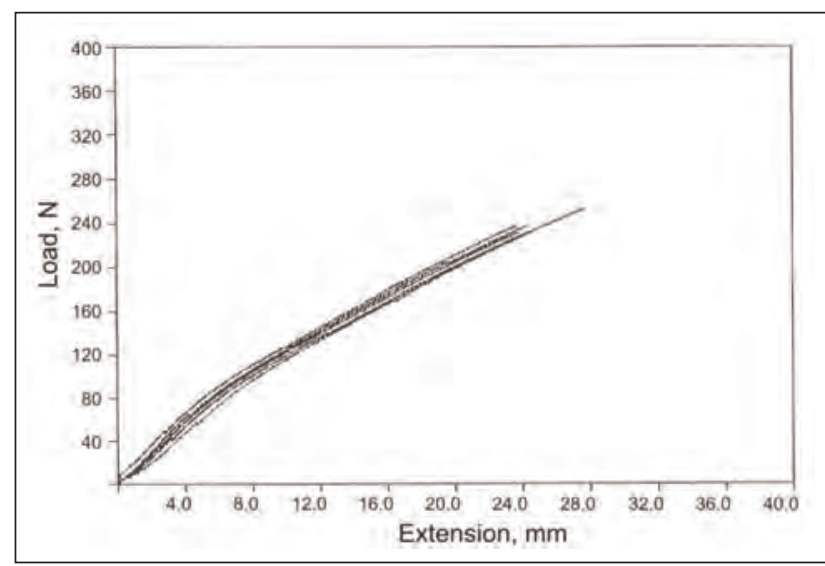

Fig. 5. Stress-strain diagram V1 - vertical

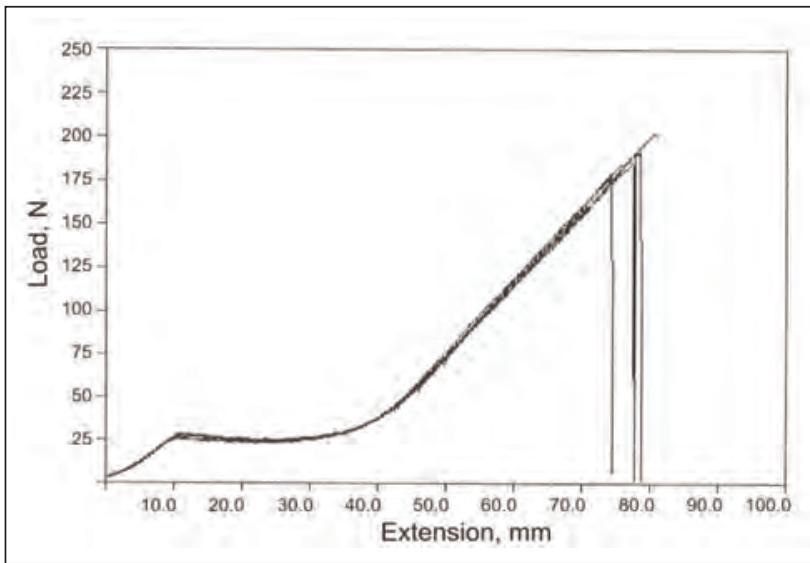

Fig. 6. Stress-strain diagram V2 - horizontal 


\begin{tabular}{|c|c|c|c|c|c|c|c|c|}
\hline \multicolumn{3}{|c|}{ Characteristics } & V1 & V2 & V3 & V3A & V4 & Standard \\
\hline \multicolumn{2}{|l|}{ Surface masses } & $\mathrm{g} / \mathrm{m}^{2}$ & 53 & 52 & 86 & 106 & 94 & SR EN 12127: 2003 \\
\hline \multicolumn{2}{|c|}{ Density, horizontal } & rows $/ 10 \mathrm{~cm}$ & 80 & 75.5 & 80 & 80 & 80 & STAS-5903-1993 \\
\hline \multicolumn{2}{|l|}{ Density, vertical } & wales $/ 10 \mathrm{~cm}$ & 140 & 185.5 & 160 & 160 & 200 & STAS-5903-1993 \\
\hline \multirow{2}{*}{ Breaking force } & horizontal & $\mathrm{N}$ & 226 & 188.4 & 171.2 & 276 & 203 & \multirow{2}{*}{$\begin{array}{c}\text { SR EN ISO 13934-1: } \\
2013\end{array}$} \\
\hline & vertical & $\mathrm{N}$ & 238 & 227 & 217 & 218 & 236 & \\
\hline \multirow{2}{*}{$\begin{array}{l}\text { Breaking } \\
\text { elongation }\end{array}$} & horizontal & $\%$ & 39.4 & 38.8 & 55.3 & 48.0 & 50.06 & \multirow{2}{*}{$\begin{array}{c}\text { SR EN ISO 13934-1: } \\
2013\end{array}$} \\
\hline & vertical & $\%$ & 12.4 & 15.4 & 26.4 & 39.5 & 29.2 & \\
\hline \multirow{2}{*}{$\begin{array}{l}\text { Thermal } \\
\text { contraction, } \\
10 \text { min., } 100^{\circ} \mathrm{C}\end{array}$} & horizontal & $\%$ & 0 & 0 & -0.51 & -1.66 & -1.19 & \multirow{2}{*}{ STAS 9139/4-90 } \\
\hline & vertical & $\%$ & 0 & 0 & -0.49 & -2.98 & -0.66 & \\
\hline \multicolumn{2}{|l|}{ Burst resistance } & $\mathrm{KPa}$ & 206.3 & 236.4 & 240.9 & 220.8 & 275.5 & \multirow{2}{*}{ EN ISO 13938-1979 } \\
\hline \multicolumn{2}{|c|}{ Burst deformation } & $\mathrm{mm}$ & 26.2 & 26.4 & 31.5 & 34.7 & 32.9 & \\
\hline \multicolumn{2}{|c|}{ Mesh size } & $\mathrm{mm}$ & $1.1 \times 0.4$ & $1 \times 1.6$ & $0.8 \times 2.3$ & $0.6 \times 0.8$ & $1 \times 1.8$ & \\
\hline
\end{tabular}

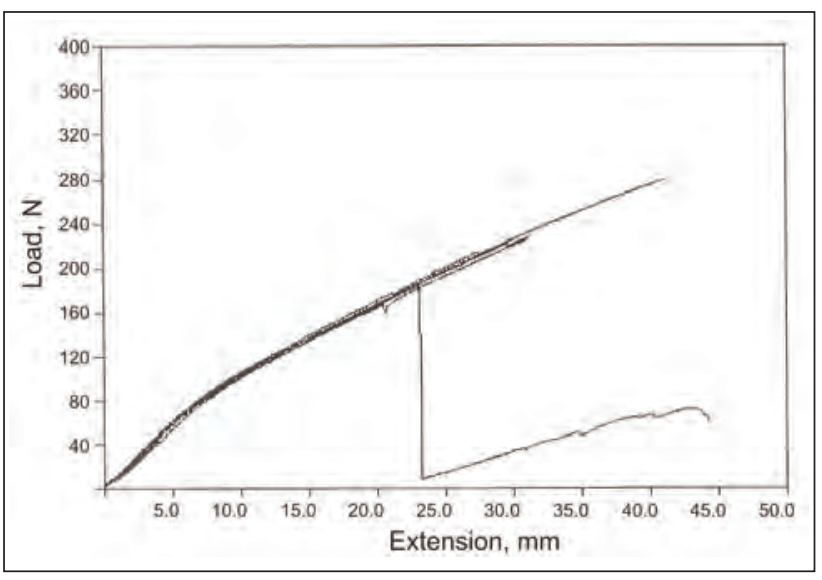

Fig. 7. Stress-strain diagram V2 - vertical

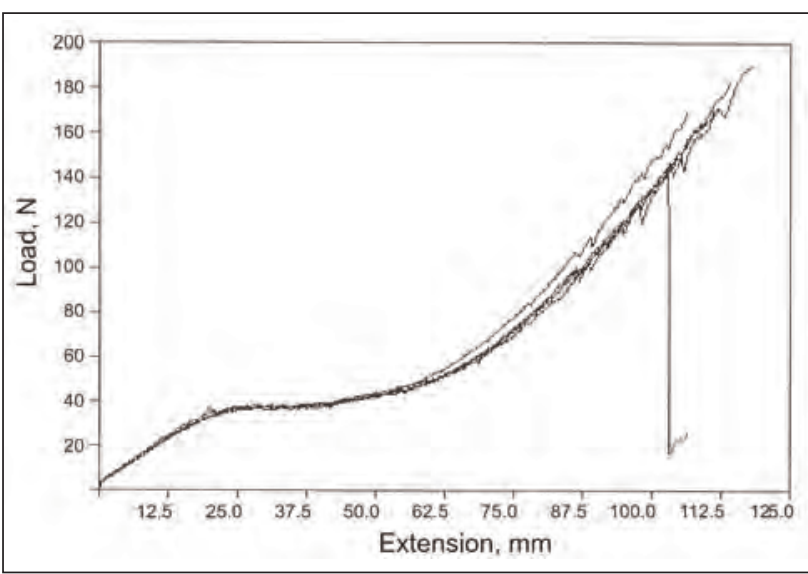

Fig. 8. Stress-strain diagram V3 - horizontal

Analyzing the diagrams, it can be observed that for the variants made from polyamide yarns, on vertical direction (or warp direction), not all the yarns have broken at the same time.
Fig. 9. Stress-strain diagram V3 - vertical

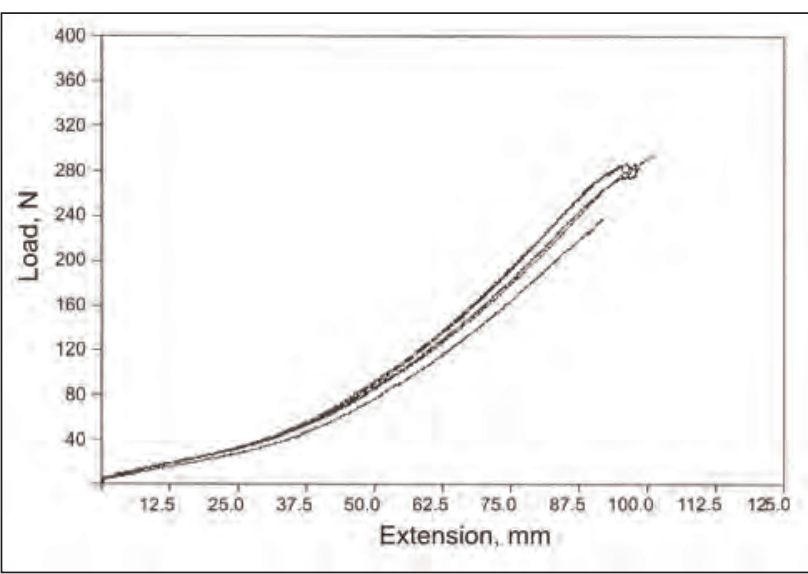

Fig. 10. Stress-strain diagram V3A - horizontal

\section{CONCLUSIONS}

From the data analysis of testing results of knitted nets variants, it can be observed that they demonstrate adequate properties compared to the corresponding agrotextiles available on the market: 


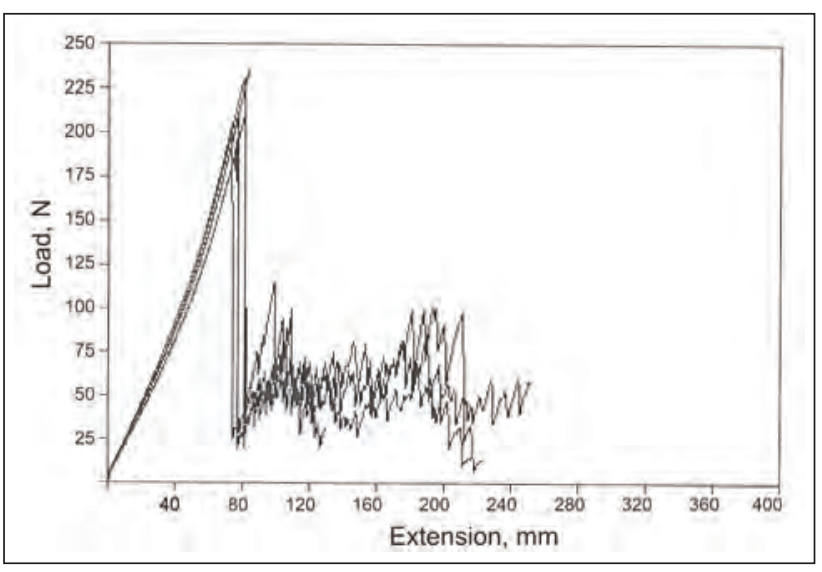

Fig. 11. Stress-strain diagram V3A - vertical

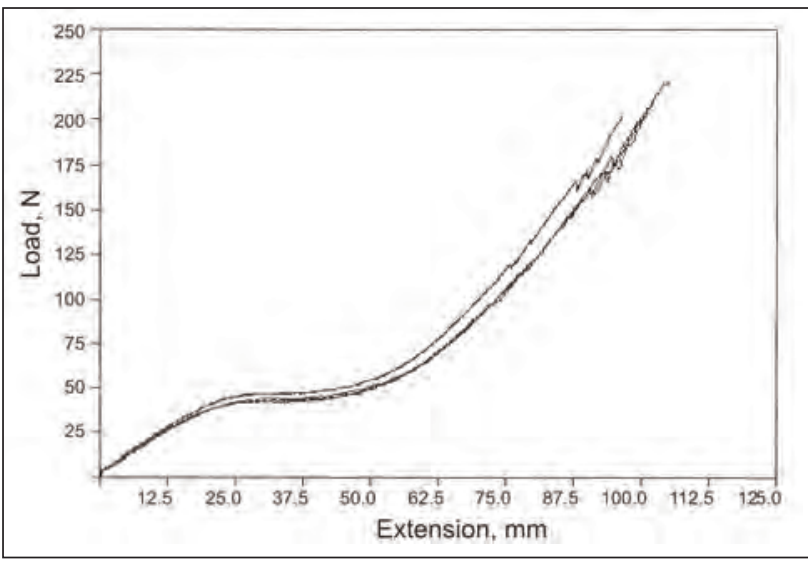

Fig. 12. Stress-strain diagram V4 - horizontal

- good mechanical properties (38-50\% elongation at break on horizontal direction, 170-280 N for breaking force on both directions and 206.3-275.5 KPa for burst resistance);

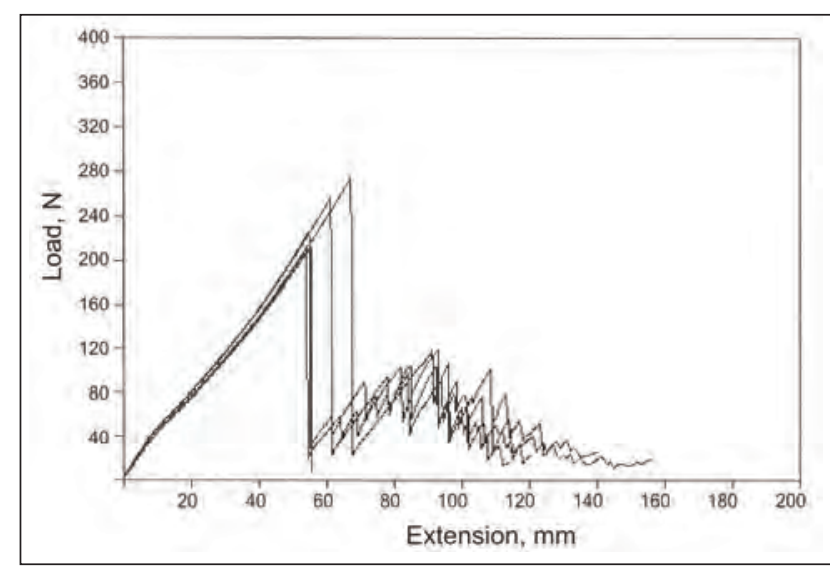

Fig. 13. Stress-strain diagram V4 - vertical

- are light weight $\left(50-110 \mathrm{~g} / \mathrm{m}^{2}\right)$;

- have very good dimensional stability (thermal contraction less than 3\%);

- mesh size is suitable for nets meant for insect protection, as pollination nets, shading or harvesting;

- the variants made from polyamide yarns have a higher elongation at break and a higher burst deformation but the variants made from polyester yarns prove better thermal properties $(0 \%$ contraction at $100^{\circ} \mathrm{C}$ in $10 \mathrm{~min}$.).

In the next stage of research, more variants from other type of yarns will be developed and the knitted nets will be tested on various crops by performing experimentations in the field.

\section{ACKNOWLEDGEMENTS}

This work was supported by a grant within the NUCLEOUS Programme, Project PN 163401 12, "Advanced knitted textile structures meant for agrotextiles".

\section{BIBLIOGRAPHY}

[1] http://textilelearner.blogspot.ro/2012/02/agro-textiles-general-property.html.

[2] http://textilelearner.blogspot.ro/2014/04/applications-of-agro-textiles.html.

[3] Mogahzy Y. EL. Engineering textiles: integrating the design and manufacture of textile products, 2008, Elsevier, CRC Press, Great Abington, England, p. 426.

[4] http://www.indiantextilejournal.com/articles/FAdetails.asp?id=2433.

\section{Authors:}

\section{RAZVAN SCARLAT 1 \\ FLOAREA PRICOP 1 \\ LEONARD RUSU²}

${ }^{1}$ The National Research and Development Institute for Textiles and Leather 16, Lucrețiu Patraşcanu str., 030508, Bucharest

${ }^{2}$ NGM Leonard SRL

Strada Fantanele Nr. 13-17, 705200, Pascani

Corresponding author:

Eng. Razvan Scarlat

e-mail: razvan.scarlat@ns.certex.ro 


\section{Applying computer systems to make orthopedic bandages}

EMILIA VISILEANU
CARMEN MIHAI
ADRIAN SALISTEAN

DOI: 10.35530/TT.068.05.1459

ALEXANDRA ENE

SABINA OLARU

\section{REZUMAT - ABSTRACT}

\section{Aplicarea sistemelor informatice în realizarea bandajelor pentru ortopedie}

Sistemul de proiectare CAD/CAM a fost utilizat pentru realizarea de tipare personalizate de bandaje elastice pentru genunchi și cot, utilizând o cabină de măsurare 3D Scan View "Human Solution Anthroscan". Caracteristica "Harta de presiune" a programului OPTITEX a fost utilizată pentru simularea presiunilor bandajelor elastice asupra brațului și piciorului. Au fost determinate caracteristicile de: forță $(N)$ pe aparatul de tip IAMADA, grosime $(\mathrm{mm}), \mathrm{masă}(\mathrm{g} / \mathrm{m})$, elasticitate (\%), prin utilizarea aparatului CETME. Analiza valorilor calculate cu softul SPSS a evidențiat pentru pragul de semnificație 0,05 corelația dintre: presiunea și grosimea, presiunea și masa, masa și grosimea, elasticitatea și grosimea bandajelor. Valorile identificate permit corelarea parametrilor de proiectare cu tipul de traumă a persoanelor cu afecțiuni ortopedice.

Cuvinte-cheie: tipare personalizate, simulare, corelație, prag de semnificație

\section{Applying computer systems to make orthopedic bandages}

The CAD/CAM design system was used to create custom patterns for knee and elbow elastic bandages using a $3 D$ Scan View "Anthroscan Human Solution". The OPTITEX program "Pressure Map" characteristic was used to simulate the elastic bandages pressures on the arm and leg. The characteristics of: force $(N)$ by means of the IAMADA type apparatus/device, thickness $(\mathrm{mm})$, mass $(\mathrm{g} / \mathrm{m})$ and elasticity (\%) using the CETME apparatus/device were determined. The analysis of the values calculated by means of the SPSS software revealed for the significance threshold of 0.05 , the correlation between: pressure and thickness, pressure and mass, mass and thickness, elasticity and thickness of the bandages. The identified values allow the correlation of the design parameters with the type of trauma of the persons with orthopedic disorders.

Keywords: customized patterns, simulation, correlation, threshold of significance

\section{INTRODUCTION}

The potential impact of smart textile for healthcare is significant; risk assessment and diagnosis are faster and more accurate, treatment and care are more effective, intelligent suits in line with societal trends; the aging population increasingly requires health monitoring and support with smart clothing could provide [1]. These new textiles are knowledge based with high added value. They can be custom made for specific end uses [2]. Consequently their economic impact is expected to be extremely high as well.

Medical textiles or Medtech is one of the most important, ever-expanding areas of technical textiles. The global medical textiles market is expected to reach USD 20.23 billion by 2022 . Non-implantable goods accounted for over $30.0 \%$ share of the global medical textiles market. Increasing incidence of injuries is fueling the demand for medical textiles in the nonimplantable goods segment.

The rise in the number of elderly population, ongoing technological advancements and increase in health consciousness are fueling the growth of global medical textiles market. Medical textiles are structures designed and made for a medical application. The number of applications is varied, ranging from a single suture thread to complex composite structures for bone replacement and from simple cleaning to advanced barrier woven fabrics used in operating theaters [3-4]. Textiles materials and products which have been designed to meet particular needs are suitable for any medical and surgical application if a combination of strength, flexibility and sometimes air humidity and permeability is necessary. The medical textiles industries have diversified with new materials and innovative design. Recently, the application of textiles has begun to go beyond the usual wound care, incontinence pads, gypsum etc., that is, a wide variety of woven, nonwoven, knitted structures which find their use more and more in a variety of medical procedures [5].

\section{EXPERIMENTAL WORK}

The CAD/CAM design system was used to create customized knee and elbow bandage patterns using a 3D body scan $[6,10]$. The first step was the 3D scan of the person for whom the product is personalized by using a 3D Scan View "Human Solution Anthroscan" (figure 1 and figure 2).

In the "measure view" interface, the dimensions of the body were taken over, both those automatically determined by the software such as body height, as well as those needed to dimension the bandages. In 


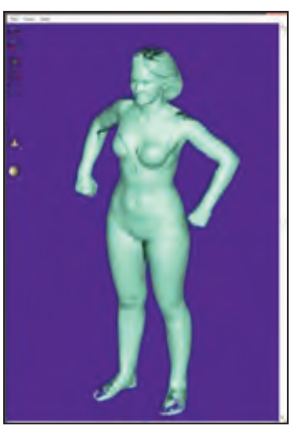

Fig. 1. 3D scanning

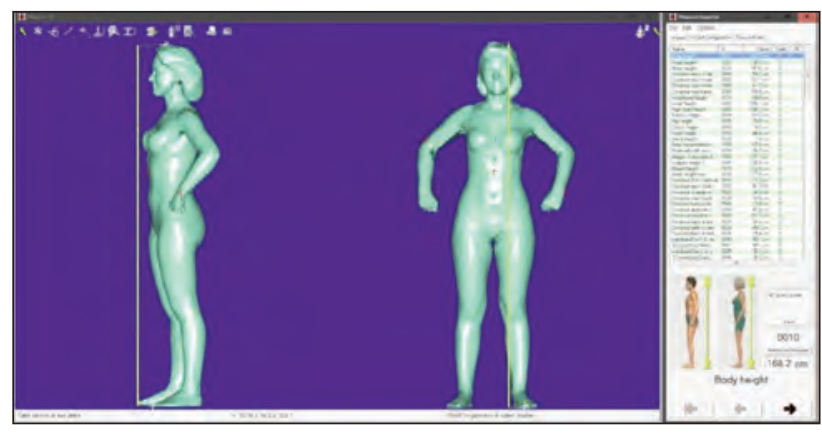

Fig. 2. 3D scanning for the measurements chart

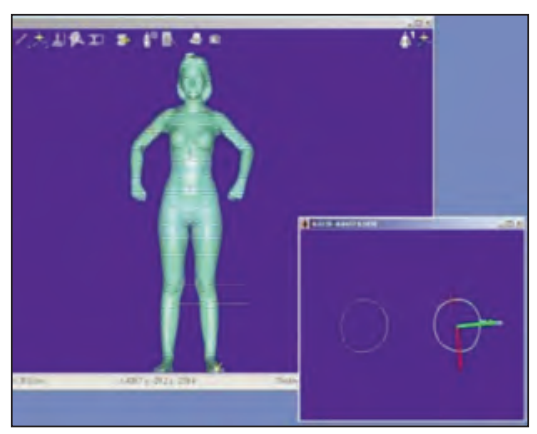

Fig. 3. "Measure view" interface

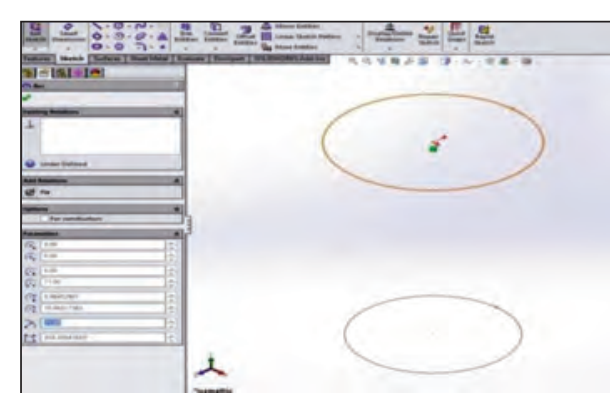

Fig. 4. Circular profiles

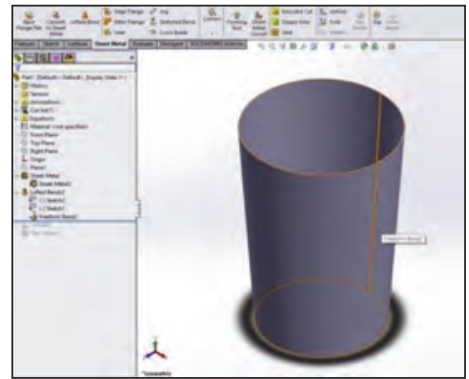

Fig. 5. Thin profile

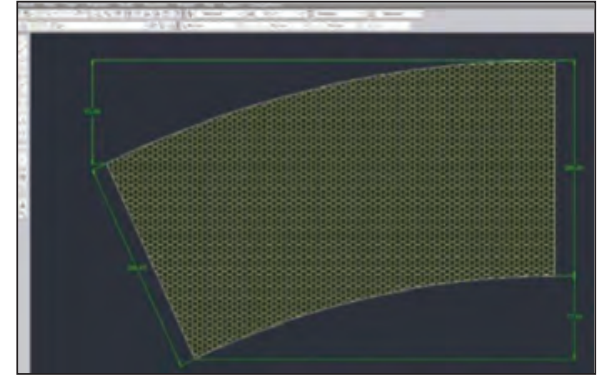

Fig. 6. DXF profile the "measure view" interface a knee plane was created after which a copy of it was created (figure 3 ) at $10 \mathrm{~cm}$ above the knee and $10 \mathrm{~cm}$ below the knee. After each plane copy operation, the circumference of the leg was measured in the sectioning plane area [7].

With these dimensions, a 3D object (in this case it is exemplified using Dassault Solidworks) was created by "drawing" two circular profiles of identical size as those measured. Thus, two circles were created, corresponding to the circumferences measured above (figure 4). The two circular profiles were used to obtain a thin profile "drawn" between the two circles (figure 5).

Figure 6 exemplifies the DXF profile on the basis of which the patterns of the elastic bandages for the leg and the elbow were obtained by printing [8].

Table 1

\begin{tabular}{|c|c|c|c|c|c|}
\hline \multirow{3}{*}{ No. } & \multirow{3}{*}{$\begin{array}{c}\text { Elastic } \\
\text { bandage } \\
\text { variant }\end{array}$} & \multicolumn{4}{|c|}{ Dimensions, [cm] } \\
\hline & & \multirow{2}{*}{$\begin{array}{c}\text { Large } \\
\text { basis } \\
{[\mathrm{mm}]}\end{array}$} & \multirow{2}{*}{$\begin{array}{l}\text { Small } \\
\text { basis } \\
{[\mathrm{mm}]}\end{array}$} & \multicolumn{2}{|c|}{ Height } \\
\hline & & & & $\begin{array}{l}\text { Knee } \\
{[\mathrm{mm}]}\end{array}$ & $\begin{array}{c}\text { Elbow } \\
{[\mathrm{mm}]}\end{array}$ \\
\hline 1 & B1V1 & 32 & 30 & 18,0 & \\
\hline 2 & B1V2 & 35 & 25 & 16,5 & \\
\hline 3 & B1V3 & 30 & 23 & 18,0 & \\
\hline 4 & B2V6 & 31,5 & 24 & 18,0 & \\
\hline 5 & B3V1 & 32 & 25 & 18 & 10 \\
\hline 6 & B3V3 & 31 & 24 & 18 & 11 \\
\hline 7 & VV1 & 31,5 & 24 & 18 & \\
\hline 8 & VV2 & 31,5 & 24 & 18 & \\
\hline 9 & MgV1 & 28,4 & 18 & 21 & 9 \\
\hline
\end{tabular}

Following the same procedure, the elbow pattern was made. Table 1 shows the dimensions of the patterns for the elastic bandages made. The elastic bandages were made by sewing.

\section{OPTITEX - TENSION MAP}

The OPTITEX program Tension Map characteristic allows inspecting the simulated clothing items through a color map which illustrates the degree of stretching, tension and distance between the clothing and the model. The tension map describes the U-tension, the V-tension, the elasticity and the distance between the clothing and the model, also carefully examining the sewing areas and identifying the exact value of the tension/distance/elasticity identified in these areas. The tension map can be used to determine the scope of the results obtained after which the changes imposed by the field of application can be made.

\section{Elastic bandage pressure map Correlation analysis}

In order to determine the pressure maps of the elastic bandages, analyzes were performed to identify the specific characteristics required by the OPTITEX Program: force $(\mathrm{N})$, thickness $(\mathrm{mm})$, mass $(\mathrm{g} / \mathrm{ml})$, and elasticity (\%) of which the bandages were made and which are shown in table 2.

The force determinations were performed by means of the IMADA apparatus (figure 7) and the elasticity determinations of the manufactured bandages were performed by means of the CETME-Italy apparatus (figure 8). 


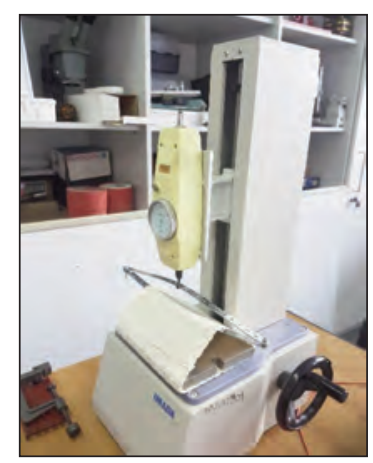

Fig. 7. IMA apparatus

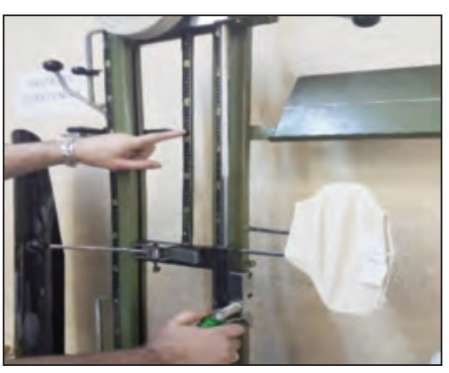

Fig. 8. CETME apparatus

Table 2

\begin{tabular}{|c|c|c|c|c|c|}
\hline \multirow{2}{*}{ No. } & \multirow{2}{*}{ Variant } & \multicolumn{4}{|c|}{ Characteristic } \\
\cline { 3 - 6 } & $\begin{array}{c}\text { Force } \\
{[\mathrm{N}]}\end{array}$ & $\begin{array}{c}\text { Thickness } \\
{[\mathrm{mm}]}\end{array}$ & $\begin{array}{c}\text { Mass } \\
{[\mathrm{gr} / \mathrm{ml}]}\end{array}$ & $\begin{array}{c}\text { Elasticity } \\
{[\%]}\end{array}$ \\
\hline 1. & B 1V1 & 38 & 2.69 & 124.2 & 64 \\
\hline 2. & B1V2 & 42 & 2.66 & 107.78 & 57 \\
\hline 3. & B1 V3 & 30 & 2.72 & 127.38 & 48 \\
\hline 4. & B2V6 & 38 & 2.82 & 109.7 & 69 \\
\hline 5. & B3 V1 & 44 & 2.89 & 67.14 & 77 \\
\hline 6. & B3V3 & 36 & 2.42 & 57.96 & 62 \\
\hline 7. & VV1 & 32 & 2.30 & 119.35 & 57 \\
\hline 8. & VV2 & 32 & 1.76 & 63.3 & 88 \\
\hline 9. & MgV1 & 10.0 & 1.79 & 46.7 & 200 \\
\hline
\end{tabular}

\section{Correlation analysis of the characteristics}

The force of association between the variables and its significance was tested using the correlation coefficient (Pearson) and the Sig coefficient [9-10]. The data obtained are shown in table 3.

Analyzing the values calculated using the SPSS, the following can be highlighted [11]:

- the significance threshold demonstrates that there is a relation between the variables studied, so there is a significant link between:
- for the significance level 0.01: pressure and elasticity;

- for the significance level 0.05: pressure and thickness, pressure and mass, mass and thickness, elasticity and thickness.

Therefore, with a probability of $95 \%$, it can be said that there is dependence between the variables (the positive sign of the correlation shows that the link between the variables is directly proportional) [11].

The form of the data distribution was checked using the non-parametric Kolmogorov-Smirnov test by means of the menu: ANALYZE - NON-PARAMETRIC TESTS-1-SAMPLE K-S (table 4).

Analyzing the Kolmogorov-Smirnov tests table, it is found that the 4 calculated levels of the KolmogorovSmirnov correspond to thresholds of significance between .244 and .807 , so they are higher than the critical threshold of .05 which allows us to assert that the assumption on normality is fulfilled.

\section{Linear regression}

Analyzing the data obtained from the predictive power information of the created model highlights the following:

- the value of the multiple correlation squared coefficient shows that $77.9 \%$ of the variant of the dependent variable is explicated by the model created. (Of course, the adjusted value of $\mathrm{R}^{2}$ must also be taken into account when judging the predictive power of the model);

- the standard deviation of the predicted dependent variable (the pressure) is of 5.94, if the values of the independent variables in the model are known. So, the value of the standard error obtained allows a good prediction of the pressure values;

- the value of $R^{2}$ remains unchanged when variables would be further added to the model, so the created model predicts well the reality;

- the significance threshold for the $F$ test reveals that the model contributes significantly to the predictive power of the regression.

Table 3

\begin{tabular}{|c|c|c|c|c|c|}
\hline & & $\begin{array}{c}\text { Pressure } \\
{\left[\mathrm{N} / \mathrm{cm}^{2}\right]}\end{array}$ & $\begin{array}{c}\text { Thickness } \\
{[\mathrm{mm}]}\end{array}$ & $\begin{array}{l}\text { Mass } \\
{[\mathrm{g} / \mathrm{ml}]}\end{array}$ & $\begin{array}{c}\text { Elasticity } \\
{[\%]}\end{array}$ \\
\hline \multirow[t]{3}{*}{ Pressure, N/cmp } & Pearson correlation & 1 & $.734\left(^{*}\right)$ & $.254\left(^{*}\right)$ & $-.830\left({ }^{* *}\right)$ \\
\hline & Sig. (2-tailed) & & .024 & .049 & .006 \\
\hline & $\mathrm{N}$ & 9 & 9 & 9 & 9 \\
\hline \multirow[t]{3}{*}{ Thickness, mm } & Pearson correlation & $.734\left(^{*}\right)$ & 1 & $.214\left(^{*}\right)$ & $-.656\left(^{*}\right)$ \\
\hline & Sig. (2-tailed) & .024 & & .041 & .050 \\
\hline & $\mathrm{N}$ & 9 & 9 & 9 & 9 \\
\hline \multirow[t]{3}{*}{ Mass, $\mathrm{g} / \mathrm{ml}$} & Pearson correlation & $.254\left(^{*}\right)$ & $.214\left(^{*}\right)$ & 1 & $-.037\left(^{*}\right)$ \\
\hline & Sig. (2-tailed) & .049 & .041 & & .025 \\
\hline & $\mathrm{N}$ & 9 & 9 & 9 & 9 \\
\hline \multirow[t]{3}{*}{ Elasticity, \% } & Pearson correlation & $-.830\left(^{* *}\right)$ & $-.656\left(^{*}\right)$ & $-.037\left(^{*}\right)$ & 1 \\
\hline & Sig. (2-tailed) & .006 & .050 & .025 & \\
\hline & $\mathrm{N}$ & 9 & 9 & 9 & 9 \\
\hline
\end{tabular}

*Correlation is significant at the 0.05 level (2-tailed).

${ }^{* *}$ Correlation is significant at the 0.01 level (2-tailed). 


\begin{tabular}{|c|c|c|c|c|c|}
\hline \multicolumn{6}{|c|}{ ONE-SAMPLE KOLMOGOROV-SMIRNOV TEST } \\
\hline & & $\begin{array}{c}\text { Pressure } \\
{\left[\mathrm{N} / \mathrm{cm}^{2}\right]}\end{array}$ & $\begin{array}{l}\text { Thickness } \\
{[\mathrm{mm}]}\end{array}$ & $\begin{array}{l}\text { Mass } \\
{[\mathrm{g} / \mathrm{ml}]}\end{array}$ & $\begin{array}{c}\text { Elasticity } \\
{[\%]}\end{array}$ \\
\hline \multicolumn{2}{|l|}{$\mathrm{N}$} & 9 & 9 & 9 & 9 \\
\hline \multirow[t]{2}{*}{ Normal parameters $(a, b)$} & Mean & 33.5556 & 2.4500 & 40.9556 & 80.2222 \\
\hline & Std. deviation & 9.98888 & .42429 & 15.24298 & 46.44292 \\
\hline \multirow[t]{3}{*}{ Most extreme differences } & Absolute & .250 & .245 & .342 & .322 \\
\hline & Positive & .148 & .162 & .342 & .322 \\
\hline & Negative & -.250 & -.245 & -.218 & -.244 \\
\hline \multicolumn{2}{|l|}{ Kolmogorov-Smirnov Z } & .749 & .736 & 1.025 & .967 \\
\hline \multicolumn{2}{|l|}{ Asymp. sig. (2-tailed) } & .628 & .651 & .244 & .307 \\
\hline
\end{tabular}

a Test distribution is Normal. b Calculated from data.

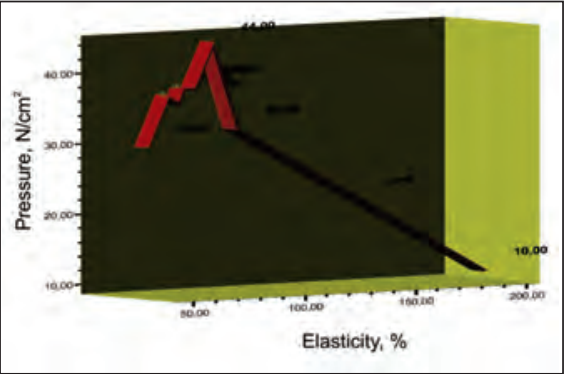

a

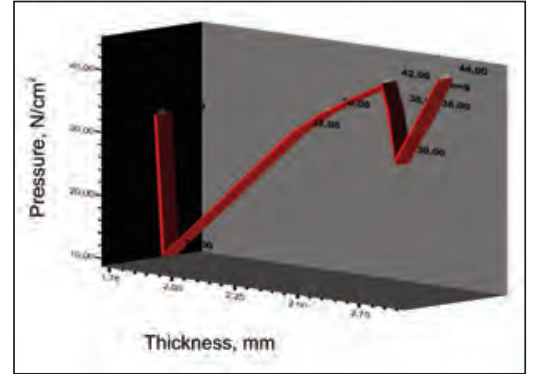

b

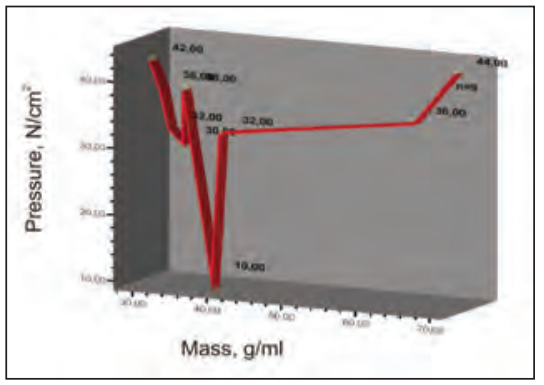

c

Fig. 9. 3D line-type graph for:

$a-$ pressure $=f($ elasticity $) ; b-$ pressure $=f($ thickness $) ; c-$ pressure $=f($ mass $)$

The ANOVA variant analysis for the regression model (which shows how efficient the prediction of the model is, knowing the independent variables) reveals that the variation explained by the model is significantly higher than the residual one, so the model is effective in prediction because $F=5.883$. Also, the significance threshold value of $0.043<0.05$ shows that we can assert with a $5 \%$ error probability that the model created significantly explains more variation than that due to other unforeseen or uncontrolled factors.

The following are highlighted:

- the non-standardized regression coefficients of the model predictors allow the writing of the regression equation:

\section{pressure $=24.1+6.51^{*}$ thickness + $+0.11^{*}$ mass $-0.14^{*}$ elasticity}

- the $t$ test shows that for the model only the elasticity predictor $(\mathrm{t}<-2)$ has an important contribution, the other variables having a less important contribution. The significance threshold of the test is below 0.05 for mass and elasticity.

The initialization of the 3D line graphs for visualizing the evolution of each independent variable in correlation with the dependent variable is presented in figure 9 (a, b, c).

\section{Pressures map}

Table 5 shows the pressure levels recorded for the elastic bandages, and table 6 presents the pressure

Table 5

\begin{tabular}{|c|c|c|c|c|c|c|c|}
\hline \multirow{2}{*}{ No. } & \multirow{2}{*}{ Variant } & \multicolumn{4}{|c|}{ Pressure $\left[\mathrm{gf} / \mathrm{cm}^{2}\right]$} & \multirow{2}{*}{ Destination } & \multirow{2}{*}{$\begin{array}{l}\text { Manufacturing } \\
\text { technology }\end{array}$} \\
\hline & & \multicolumn{2}{|c|}{ Min. } & \multicolumn{2}{|c|}{ Max. } & & \\
\hline 1 & B1V1 & \multicolumn{2}{|c|}{6.0} & \multicolumn{2}{|c|}{21.0} & knee & weaving \\
\hline 2 & B1V2 & \multicolumn{2}{|c|}{4.0} & \multicolumn{2}{|c|}{19.0} & & \\
\hline 3 & B1V3 & \multicolumn{2}{|c|}{5.0} & \multicolumn{2}{|c|}{23.0} & & \\
\hline 4 & B2V6 & \multicolumn{2}{|c|}{6.0} & \multicolumn{2}{|c|}{24.0} & & \\
\hline 5 & B3V1 & 7.0 & 17.0 & 24.0 & 50.7 & elbow & \\
\hline 6 & B3V3 & 5.0 & 21.0 & 3.0 & 50.0 & & \\
\hline 7 & VV1 & \multicolumn{2}{|c|}{5.0} & \multicolumn{2}{|c|}{19.0} & knee & \\
\hline 8 & VV2 & \multicolumn{2}{|c|}{4.0} & \multicolumn{2}{|c|}{20.0} & & \\
\hline 9 & MgV1 & 2.0 & 10.0 & 35.5 & 35.5 & elbow & knitting \\
\hline
\end{tabular}




\begin{tabular}{|l|l|l|l|l|l|}
\hline Variant & Pressures map & Variant & Pressures map & Variant & Pressures map \\
\hline B1V1 & & & & & \\
\hline
\end{tabular}

Table 7

\begin{tabular}{|l|c|c|c|c|c|}
\hline Variant & Pressures map & Variant & Pressures map & Variant & Pressures map \\
\hline B3V1 & & & B3V3 & & \\
\hline
\end{tabular}

maps for the knee and elbow elastic bandages made by means of the weaving and knitting technology.

The analysis of the data presented in table 5 shows the following aspects:

a) Woven elastic bandages for the knee:

- the minimum pressure value exerted by the elastic bandages for the knee is within the limits of 4-7 $\mathrm{gf} / \mathrm{cm}^{2}$; the pressure of $4 \mathrm{gf} / \mathrm{cm}^{2}$ is recorded for the B1V2 and VV2 variants and the value of $7 \mathrm{gf} / \mathrm{cm}^{2}$ for the B3V1 variant;

- the maximum pressure value for the knee bandages is within the limits of $19-24 \mathrm{gf} / \mathrm{cm}^{2}$; the value of $19 \mathrm{gf} / \mathrm{cm}^{2}$ is for the B1V2 and VV1 variants and the value of $24 \mathrm{gf} / \mathrm{cm}^{2}$ for the B2V6 and B3V1 variants;

- the difference between the maximum and minimum values is within the limits of: $10-18 \mathrm{gf} / \mathrm{cm}^{2}$.

b) Knitted elastic bandage for elbow:

- the minimum value of the pressure is of $2.0 \mathrm{gf} / \mathrm{cm}^{2}$ with $50 \%$ lower than the inferior limit recorded for the knee woven bandages;

- the maximum value of the pressure is of $10 \mathrm{gf} / \mathrm{cm}^{2}$ with circa $48 \%$ lower than for the knee woven bandages.

industroำ textila
Of the elastic bandages with $10 \mathrm{~cm}$ width (woven and knitted) the elbow elastic bandages were made. Table 5 presents the pressures values recorded for these variants and table 7 shows the afferent pressure maps.

From the comparative analysis of the data on the pressures values of the woven and knitted elastic bandages for knees and elbows presented in table 5, the following aspects are found:

- for the woven and knitted elastic bandages made for elbow, the minimum and maximum pressures values are higher than those for the knee due to the distribution of the force $(\mathrm{N})$ to a smaller area (10 cm width instead of $20 \mathrm{~cm}$ );

- the minimum value of the pressure for the woven bandages is of $5 \mathrm{gf} / \mathrm{cm}^{2}$ and for the knitted bandage of $2 \mathrm{gf} / \mathrm{cm}^{2}$;

- the maximum values are around the value of 50 $\mathrm{gf} / \mathrm{cm}^{2}$ (50.0 $\mathrm{gf} / \mathrm{cm}^{2}$ B3V3 and $50.7 \mathrm{gf} / \mathrm{cm}^{2}$ B3V1) with circa $50 \%$ higher than that of the similar bandage for the leg.

For this type of bandage, the difference between the max. and min. values is very high and this is a fact 
which highlights a high degree of unevenness of the pressure exerted by the elastic bandage.

\section{CONCLUSIONS}

The elastic bandages made by means of weaving and knitting technologies can be customized by using the CAD/CAM design software. The correlation analysis of the characteristics highlights the correlation between:

- for the significance level 0.01: pressure and elasticity;
- for the significance level 0.05: pressure and thickness, pressure and mass, mass and thickness, elasticity and thickness.

The pressures map made by means of the OPTITEX program revealed the degree of unevenness of the pressures exercised by the elastic bandages which is very high for the elbow.

\section{ACKNOWLEDGMENTS}

The research project is carried out in the frame work of The Nucleus Program of The INCDTP Bucharest, Romania.

\section{BIBLIOGRAPHY}

[1] Atkinson K. (2004) Australian developments in textiles and fibre technology, In: CSIRO Proceeding of New Technologies and Smart Textiles for Industry and Commerce, London, Institute of Nanotechnology.

[2] Jevšnik S., Pilar T., Stjepanović Z., Rudolf A. Virtual prototyping of garments and their fit to the body. In: DAAAM International scientific book 2012. Vienna: DAAAM International Publishing, 2012, pp. 601-618.

[3] Rudolf A., Gorlichova, L., Kirbis, J., Repnik, J., Salobir, A., Selimov, I., Drstvensek, I. New technologies in the development of ergonomic garments for wheelchair users in a virtual environment, In: IndustriaTextila, ISSN 1222 -5347 , vol. 68, nr. 2, pp. 83-84.

[4] Goswami A., Ganguli S., Chatterjee B.B. Anthropometric characteristics of disabled and normal Indian men. In: Ergonomics, 1987, vol. 30, no. 5, pp. 817-823.

[5] Ene, A., Mihai, C. Noi generatii de biomateriale cu structuri textile, In: Industria Textila, ISSN 1222-5347 vol. 53, nr. 1, 2002, pp. 20-23.

[6] *** Proiectare CAD/CAM - Dasault Systemes.

[7] Wang, G.G. Definitions and review of virtual prototyping. In: Journal of Computing and Information Science in Engineering (Transactions of the ASME), 2003, vol. 2, no. 3, pp. 232-236.

[8] Rudolf, A., Stjepanović, Z., Jevšnik, S., Cupar, A. Research on the applicability of CASP methodology for nonstandard body shapes' garment pattern design. In: Proceedings, 16 $6^{\text {th }}$ World Textile Conference AUTEX 2016, Ljubljana, Slovenia, 8-10 June 2016, (CD version), pp. 1-7.

[9] Lungu O. Ghid introductiv pentru SPSS 10.0 - Psihologie experimentală şi aplicată, In: Editor Erota, 2001.

[10] Aileni R.M., Ciocoiu M., Fărîmă D. Modeling and 3D simulation of the garment product. In: IndustriaTextila, 2011, vol. 62, no. 3, pp. 141-145.

[11] Cojocaru, N.N. et al, Metode statistice aplicate în industria textilă, Editura Tehnică, Bucureşti, 1986.

\section{Authors:}

\section{EMILIA VISILEANU \\ CARMEN MIHAI \\ ALEXANDRA ENE \\ SABINA OLARU \\ ADRIAN SALISTEAN}

The National Research and Development Institute for Textile and Leather Bucharest, Romania

\section{Corresponding author:}

EMILIA VISILEANU

e-mail: visilean@ns.certex.ro 


\section{Adsorption and decolorization effect of cocoanut activated carbon for simulated disperse dye wastewater}

DOI: $10.35530 / 1 T .068 .05 .1315$

LIN-LIN YAN
ZHUAN-YONG ZOU
JIAN-DI ZHOU
LIN-MIN ZHU

LIAN-YIN ZHAO DANG-PING ZHU

\section{REZUMAT - ABSTRACT}

Efectul de adsorbție și de decolorare a cărbunelui activ din nucă de cocos pentru apele reziduale rezultate în urma procesului de vopsire cu coloranți de dispersie

Această lucrare analizează efectele granulației cărbunelui activ de tip granular, temperatura și timpul de absorbție, valoarea și concentrația pH-ului apei reziduale rezultate în urma procesului de vopsire și structura colorantului de dispersie asupra vitezei de decolorare a cărbunelui activ în apele reziduale rezultate în urma procesului de vopsire, care pot fi utilizate pentru a investiga efectul de adsorbție al carbonului activ granular pentru apa reziduală rezultată în urma procesului de vopsire. Rezultatele cercetării arată că viteza de decolorare a cărbunelui activ din nucă de cocos, utilizată pentru adsorbția colorantului de dispersie, crește la o funcție pătratică odată cu creșterea granulației cărbunelui activ de tip granular și a temperaturii de absorbție și, de asemenea, crește exponențial cu prelungirea timpului de adsorbție. Cu toate acestea, viteza de decolorare a cărbunelui activ din nucă de cocos utilizat pentru adsorbția coloranului de dispersie scade la o funcție pătratică odată cu creșterea valorii pH-ului apei reziduale rezultate în urma procesului de vopsire și, de asemenea, scade exponențial cu creșterea concentrației de apă reziduală rezultată în urma procesului de vopsire. Mai mult, viteza de decolorare a cărbunelui activ din nucă de cocos este mai scăzută atunci când numărul de grupe polare ale colorantului de dispersie este mai mare.

Cuvinte-cheie: cărbune activ din cocos, apă reziduală cu coloranți de dispersie, absorbție și decolorare, factor de influență

\section{Adsorption and decolorization effect of cocoanut activated carbon for simulated disperse dye wastewater}

This paper analyzed the effects of granular activated carbon mesh size, absorption temperature and time, dye wastewater $\mathrm{pH}$ value and concentration, and structure of disperse dye on the decolorization rate of activated carbon in dye wastewater, which can be used to investigate the adsorption effect of granular activated carbon for the dye wastewater. The research results show that the decolorization rate of cocoanut activated carbon used to adsorb disperse dye increases at a quadratic function with the increase of the granular activated carbon mesh size and absorption temperature, and it also increases exponentially with the extension of absorption time. However, the decolorization rate of cocoanut activated carbon used to adsorb disperse dye decreases at a quadratic function with the increase of dye wastewater $\mathrm{pH}$ value, and it also decreases exponentially with the increase of dye wastewater concentration. Furthermore, the decolorization rate of cocoanut activated carbon is lower when the number of polar groups of disperse dye is larger.

Keywords: cocoanut activated carbon, disperse dye wastewater, absorption and decolorization, influencing factor

\section{INTRODUCTION}

Industrial dye wastewater may contain heavy metals and toxic components due to dyeing substances and chemicals [1]. The unreasonable treatment of industrial dye wastewater will cause environmental pollution and endanger human health. So it is vital to the reasonable treatment of the dyes in wastewater. Disperse dye is kind of hydrophobic dye with small molecules, simple structure and no ionizable watersoluble group. Disperse dyes, which are widely used for coloring polyester textiles, are not readily degraded by biological treatments owing to their insolubility in water, and thus, fairly large amounts (up to 10\%) are discharged in effluent [2]. Moreover, disperse dye wastewater contains a large number of intermediates and non-recycled dyes, which is a kind of industrial organic wastewater. So the treatment of this dye wastewater is rather difficult on account of its high chroma and high concentration of organic matter as well as strong toxicity. In recent years, an increasing number of researchers are starting to focus on the treatment of the dye wastewater, in order to choose a suitable decolorizing adsorption material and master the law of adsorption and decolorization for disperse dyes. Pourbabaee et al. studied the possibility of decolorizing and detoxifying the dyeing effluents containing a disperse dye via aerobic biotreatment [3]. Arora et al. investigated the decolorization of a monoazo red disperse dye in a mineral salt medium by a Bacillus firmus isolated [4]. Carneiro's study showed that the photo-degradation was an effective method to treat selected disperse dye in wastewater effluent [5]. Kurade et al. developed a bacterial-yeast 
consortium BL-GG to decolorize the textile industry effluent containing disperse dye Scarlet RR, concluding that the newly developed bacterial-yeast consortium BL-GG had an efficient decolorization at experiment conditions [6]. Sirianuntapiboon et al. tested the disperse dye adsorption capacity of both autoclaved and resting bio-sludge. From their study, it could be seen that the resting bio-sludge of a wastewater treatment system has a high adsorption ability and could be used to absorb the disperse dye in textile wastewater [7]. Paschoal et al. proposed a prospective method of a photo-eletrocatalytic oxidation treatment system for obtaining disperse dyes from industrial dye wastewater. The study found that photo-electrocatalytic oxidation is an efficient means of reducing the concentration of disperse dyes in wastewater [8]. Merzouk et al. compared the decolourization effect of chemical coagulation and electrocoagulation with aluminum electrodes on disperse red dye in textile wastewater. Experimental results showed that CC was a robust and simple process for removing disperse red dye from a textile wastewater when $\mathrm{Al}_{2}\left(\mathrm{SO}_{4}\right)_{3}$ was used as the coagulant [9]. Ma et al used the technology of coagulation-catalytic oxidation-hydrolytic acidification biological contact oxidation to treat high concentration and difficult degradation of disperse dye wastewater, showing that $\mathrm{UV} / \mathrm{TiO}_{2} / \mathrm{O}_{3}$ has a higher removal rate of $\mathrm{COD}$ and chroma of disperse dye wastewater [10]. Liu et al. treated different types of disperse dye wastewater by using tubular ultra-filtration membrane technology, which can be verified that it effectively intercepts the disperse dye particles in the wastewater, realizing the recovery of disperse dyes from wastewater [11]. In addition, the activated carbon has a huge advantage in terms of the adsorption and decolorization for wastewater due to the extended surface area, a high degree of surface reactivity and tailored pore distribution [12]. Özgül Gerçel et al. investigated the adsorption of disperse orange 25 onto activated carbon from aqueous solution in a batch system, indicating that $\mathrm{H}_{2} \mathrm{SO}_{4}$ impregnated activated carbon from Euphorbia rigida was a good adsorbent for the removal of disperse orange 25 from aqueous solutions [13]. Ahmad et al. obtained the most appropriate preparation conditions for waste-derived activated carbons to remove the disperse dye from aqueous solution [14]. Lu et al. applied the D-DBD plasma coupling with GAC adsorption process to remove the pentachlorophenol from wastewater. Experimental results demonstrated this process and exhausted GAC treatment have a considerable potential for a large amount of wastewater treatment [15]. LAN et al. compared the adsorbed and decolorant effect of coconut shell, nut shell and coal activated carbons on reactive dye wastewater, indicating that the cocoanut activated carbon has relatively good adsorption and decolorization effect [16]. Tang et al. used the coconut shell activated carbon to absorb N,N-dimethyl formamide with low concentration in wastewater, proving that $0.850-0.425 \mathrm{~mm}$ coconut shell activated carbon has a better adsorption ability than $2.36-0.850 \mathrm{~mm}$ activated carbon for the low concentration of DMF in wastewater [17]. Therefore, on the basis of previous researches, this paper analyzes the adsorption and decolorization effect of cocoanut activated carbon on disperse dye wastewater, in order to understand the influence of granular activated carbon mesh, adsorption decolorant conditions and the disperse dye structure on the adsorption decolorant rate of cocoanut activated carbon, which can provide scientific basis and some reference value for the development and utilization of wastewater treatment technology and related products.

\section{EXPERIMENTAL PARTMATERIALS AND EXPERIMENTAL METHODS}

\section{Screening of cocoanut activated carbon}

Cocoanut activated carbon (Gongyi Pengcheng filter material Co. Ltd.) was used in this study. The particle size of coconut activated carbon was characterized by the mesh (the pore number of sieve mesh/2.54 $\mathrm{cm})$. The cocoanut activated carbon was screened by a variety of different mesh sieves (18-mesh, 24-mesh, 30-mesh, 40-mesh, 50-mesh, and 60-mesh). For studying the influence of coconut activated carbon particle size on the performance of its adsorption and decolorization, two different sieves were used to screen the cocoanut activated carbon. For example, the average mesh of coconut activated carbon, 35-mesh, can be selected by using the 30-mesh and 40-mesh sieves. In this paper, we obtained the cocoanut activated carbon with different particle size, 21-mesh, 35-mesh, 45-mesh and 55-mesh.

\section{SEM observation of activated carbon particles}

The surface morphology structure of cocoanut activated carbon was analyzed with a Mini-SEM scanning electron microscope (SNE-3000M, South Korea SEC Co., Ltd.). After the sample was treated by spray-gold with Mcm-100 spray coating apparatus under a current of 38-39 mA for $3 \mathrm{~min}$, the samples were observed at an acceleration voltage of $30 \mathrm{kV}$ under high vacuum.

\section{Preparation of simulated disperse dye wastewater}

Using citric acid, anhydrous $\mathrm{Na}_{2} \mathrm{HPO}_{4}, \mathrm{NaOH}$ and $\mathrm{HCl}$, and distilled water, the solution of $\mathrm{pH}=3,5,5.4$, 7,10 and 12 was formulated with the help of a $\mathrm{pH}$ meter.

A certain amount of C.I. disperse blue 56 dye (Zhejiang Runtu Co., Ltd.) was added to the solution of $\mathrm{pH}=5.4$ with different capacity prepared, and then obtained the simulated disperse blue dye wastewater whose concentration is $10 \mathrm{mg} / \mathrm{L}, 30 \mathrm{mg} / \mathrm{L}, 40 \mathrm{mg} / \mathrm{L}$, $50 \mathrm{mg} / \mathrm{L}, 70 \mathrm{mg} / \mathrm{L}, 80 \mathrm{mg} / \mathrm{L}, 100 \mathrm{mg} / \mathrm{L}$. The disperse dyes were fully dissolved by using the $\mathrm{L}-12 \mathrm{C}$ oscillating dyeing machine, under the conditions of a temperature of $80^{\circ} \mathrm{C}$, the shock velocity of $50 \mathrm{r} / \mathrm{min}$ and 50 min concussion. The simulated dye wastewater of 
disperse blue prepared was cooled to room temperature for standby dye wastewater. The simulated wastewater of C.I. disperse red 127 (Sumitomo Chemical Co., Ltd.) with $40 \mathrm{mg} / \mathrm{L}$ by was also prepared by the same method mentioned previously. $8 \mathrm{mg} \mathrm{C.I}$. disperse blue 56 dye was added to $200 \mathrm{ml}$ solution with different $\mathrm{pH}$ values prepared. The simulated wastewater of disperse dye with $40 \mathrm{mg} / \mathrm{L}$ under different $\mathrm{pH}$ values was obtained, according to the preparation conditions of the second steps.

\section{Absorption and decolorization of activated carbon}

$3 \mathrm{~g}$ cocoanut activated carbon was added to different kinds of $30 \mathrm{ml}$ simulated dye wastewater in the conical flask, and quickly placed in the L-12C staining shock machine with $50 \mathrm{r} / \mathrm{min}$ hock speed and $10 \mathrm{~min}$ shock time at different temperature environment $\left(25^{\circ} \mathrm{C}, 40^{\circ} \mathrm{C}, 55^{\circ} \mathrm{C}, 70^{\circ} \mathrm{C}\right.$ and $\left.80^{\circ} \mathrm{C}\right)$, in order to analyze the absorption and decolorization effect of activated carbon.

\section{Calculation of decolorization rate}

After the dye in simulated wastewater was absorbed by the cocoanut activated carbon, a small amount of decolored effluent with a syringe was injected into the centrifugal tube, which was quickly placed into a miniature centrifuge to obtain clean liquid in the supernatant for the test of absorbance. The centrifugation of the decolored effluent was carried out under the conditions of $10000 \mathrm{r} / \mathrm{min}$ rotation speed, $5 \mathrm{~min}$ centrifugal time. The absorbance of centrifuged clean liquid was measured by the UV-2450 ultraviolet spectrophotometer.

The decolorization rate of the cocoanut activated carbon, $\gamma$, can be calculated according to the absorbance value of the simulated disperse dye wastewater adsorbed before and after, as shown in the equation (1).

$$
\gamma(\%)=\left(1-a_{1} / a_{0}\right) \times 100 \%
$$

where $a_{0}$ is the absorbance of simulated disperse dye wastewater before adsorption, $a_{1}$ is the absorbance of simulated disperse dye wastewater after adsorption.

\section{RESULTS AND DISCUSSIONS}

\section{Effect of activated carbon mesh size}

The effects of adsorption and decolorization of cocoanut activated carbon with different mesh sizes were analyzed and illustrated in figure 1. Simulated dye wastewater of $\mathrm{pH} 5.4$ and disperse dyes $40 \mathrm{mg} / \mathrm{L}$ was selected to complete absorption test. The adsorption temperature is $25^{\circ} \mathrm{C}$

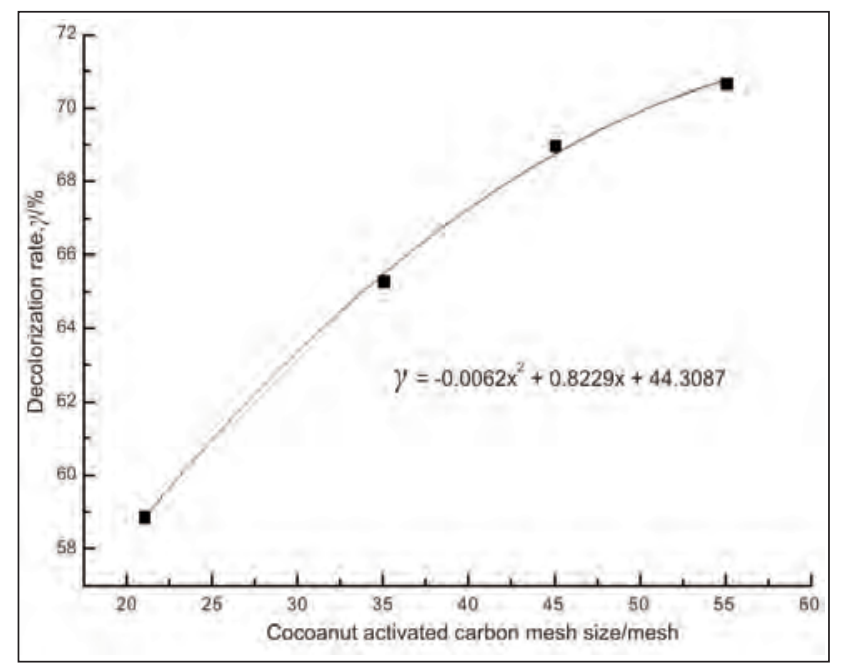

Fig. 1. Effects of cocoanut activated carbon mesh size on the decolorization rate

and the adsorption time is $10 \mathrm{~min}$. As figure 1 shows, with the increase of cocoanut activated carbon mesh, the absorbing and decoloting effect of the simulated disperse dye wastewater is better. There is a parabola curve relationship between the decolorization rate of activated carbon and its mesh size, which can be verified by the high correlation coefficient of function $\mathrm{R}^{2}$ being 0.9961 . Increasing the cocoanut activated carbon mesh is more useful to improve its effect of adsorption and decolorization. The higher activated carbon mesh number, its absorbing and decoloring effect is better. The reason is that with the increase of activated carbon mesh, the pore number of the activated carbon increases, and it has more developed mesopores and micropores, resulting in the increase of its specific surface area, as shown in figure 2 . The

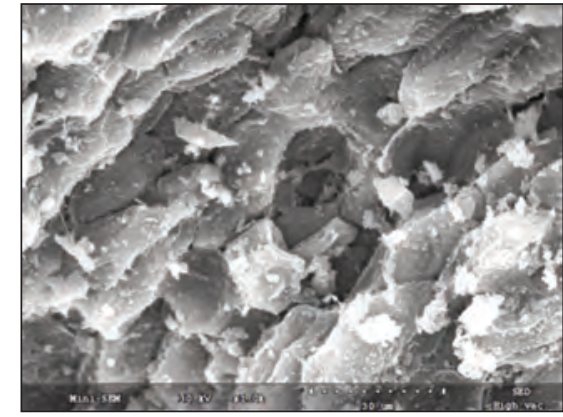

(a) 21-mesh

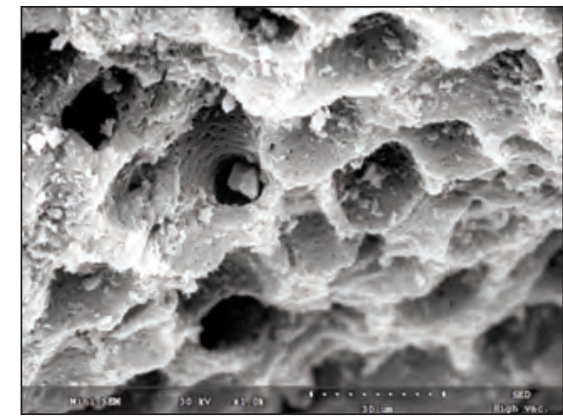

(c) 45-mesh

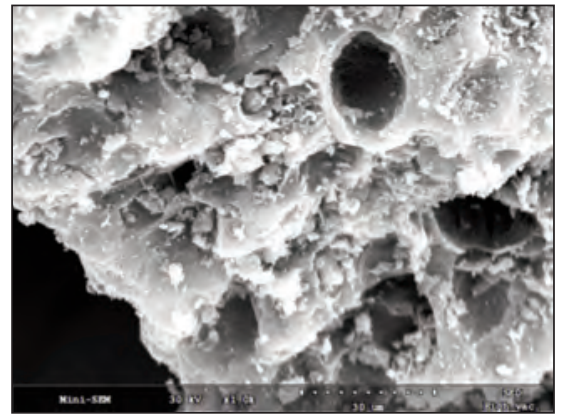

(b) 35-mesh

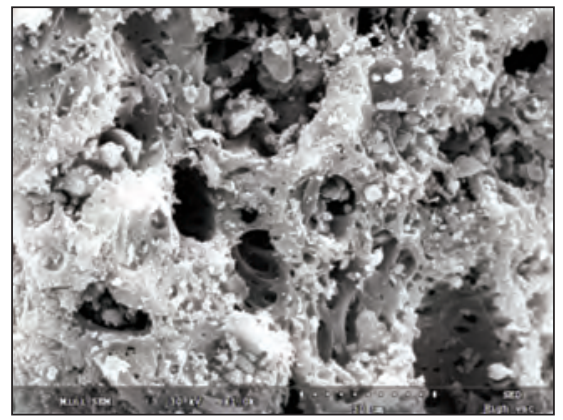

(d) 45-mesh

Fig. 2. The SEM photographs of different mesh sizes of cocoanut activated carbon $(\times 1000)$ 
higher the activated carbon, its adsorption capacity for the dye is stronger.

\section{Effect of adsorption temperature}

The effects of adsorption and decolorization of cocoanut activated carbon with 45-mesh size at 10 min adsorption time under different adsorption temperature environment $\left(25^{\circ} \mathrm{C}, 40^{\circ} \mathrm{C}, 55^{\circ} \mathrm{C}, 70^{\circ} \mathrm{C}\right.$ and $85^{\circ} \mathrm{C}$ ) were evaluated, as shown in figure 3 . The dye concentration of simulated wastewater with $\mathrm{pH}$ 5.4 is $40 \mathrm{mg} / \mathrm{L}$. Figure 3 shows that the decolorization rate of cocoanut activated carbon increases with the increase of adsorption temperature, ranging from $25^{\circ} \mathrm{C}$ to $85^{\circ} \mathrm{C}$. The relationship between the decolorization rate of activated carbon and adsorption environment's temperature can be described by the parabola function whose correlation coefficient $R^{2}$ is 0.98 , showing a higher fitting degree. When the adsorption temperature exceeds $60^{\circ} \mathrm{C}$, the effect of adsorption and decolorization for cocoanut activated carbon increases slowly. This phenomenon can be understood from the thermal motion mechanism of molecules. The higher the temperature, the thermal motion of dye molecular is more frequent, resulting in the increase of contact frequency between the dye molecular and activated carbon, which reduces the time that dye molecules are adsorbed by activated carbon, and then increases the decolorization effect of activated carbon. On the other hand, when the activated carbon adsorption capacity per unit mass has been saturated gradually, the dye molecular thermal motion is no longer the main factor, which influence the absorbing effect of activated carbon. Moreover, the adsorption reaction is an exothermic reaction, resulting in the increase of de-adsorption of the dye molecules adsorbed by activated carbon due to a higher temperature. Therefore, these make the slope of the decolorization rate $v_{s}$. adsorption temperature decrease with the increase of adsorption temperature. So the appropriate adsorption environment temperature of cocoanut activated carbon will

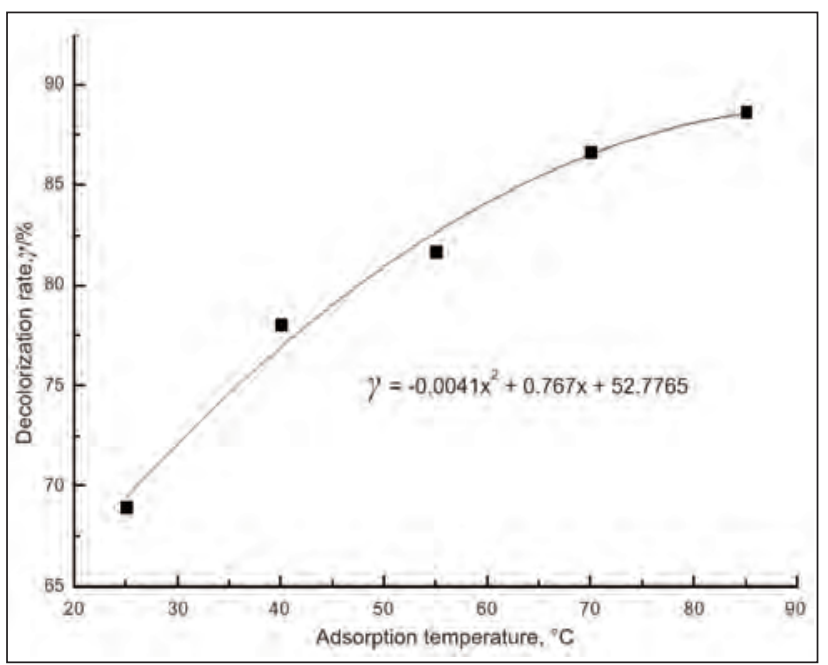

Fig. 3. Effects of adsorption temperature on the decolourization rate of cocoanut activated carbon affect the adsorbed and decolorant effect and the energy consumption cost to deal with wastewater.

\section{Effect of adsorption time}

The effect of adsorption and decolorization of cocoanut activated carbon with 45-mesh size at the adsorption temperature $25^{\circ} \mathrm{C}$ under different adsorption time (5 min, $10 \mathrm{~min}, 15 \mathrm{~min}, 20 \mathrm{~min}$ and $25 \mathrm{~min}$ ) was presented in figure 4 . The dye concentration of simulated wastewater is $40 \mathrm{mg} / \mathrm{L}$. As figure 3 showing, the decolorization rate of coconut activated carbon for the simulated disperse dye molecular varies according to the exponential function with high correlation coefficient $R^{2}=0.9851$. In initial stage of adsorption and decolorization of the activated carbon, the decoloring effect of coconut activated carbon on disperse dye promotes quickly with the increase of adsorption time, while after the adsorption time for more than $15 \mathrm{~min}$, the decolorization rate of the activated carbon for disperse dye increases very slowly, and it tends to be a constant when the adsorption time is prolonged. The main reason for this phenomenon is that, in the initial stage of adsorption, the internal pore surface of activated carbon quickly adsorbs disperse dye molecules on activated carbon by means of van der Waals forces, thereby the decolorization rate of the activated carbon increased rapidly. However, when a large number of dye molecules were adsorbed by the surface of activated carbon, dye molecules in solution are difficult to be adsorbed by activated carbon due to the resistance from dye molecules distributed on the activated carbon. Moreover, as the adsorption time goes on, the activated carbon pores become smaller due to the aggregation of dye molecules, resulting in being difficult for further absorption. Ultimately, the disperse dye molecules on the activated carbon and dye molecules in wastewater solution reach a dynamic balance of adsorption, so the decolorization rate tends to be a constant. Therefore, according to this rule, reasonable control of adsorption time is helpful

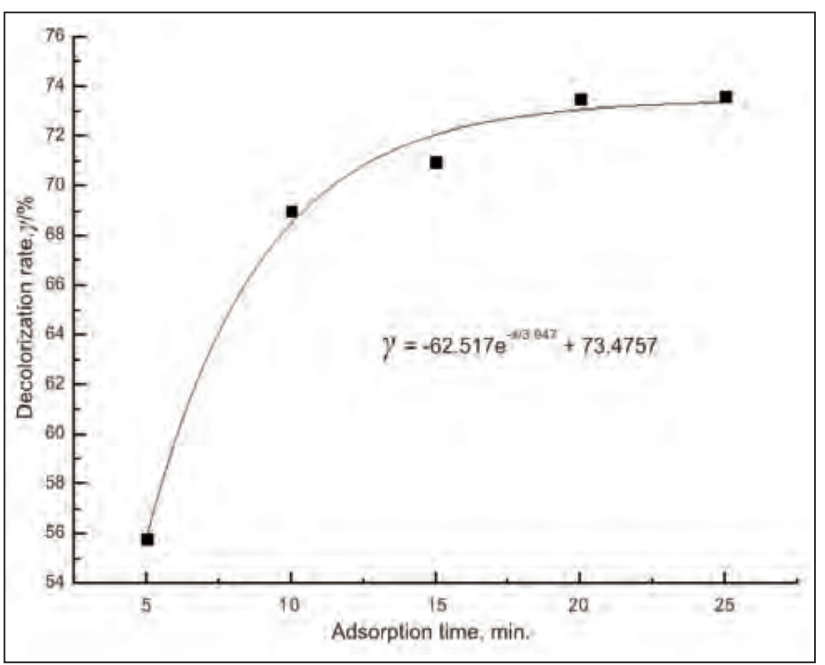

Fig. 4. Effects of adsorption time on the decolourization ratio of cocoanut activated carbon 
to reduce the cost of wastewater treatment and its treatment efficiency in the actual process of wastewater treatment.

\section{Effect of dye wastewater pH}

The effect of adsorption and decolorization of cocoanut activated carbon with 45-mesh size at adsorption temperature $25^{\circ} \mathrm{C}$ and adsorption time 10 min under different dye solution $\mathrm{pH}$ values $(3,5$, 7,10 and 12) was given in figure 5 . It can be revealed that the decolorization rate of coconut activated carbon for disperse dye molecules in a weak acid environment is the highest and the decolorization rate of activated carbon decreases with the increase of $\mathrm{pH}$ value from 5 to 12 , reaching the lower decoloring effect in the strong alkaline environment. The relationship between the decolorization rate $v_{s}$. the dye solution $\mathrm{pH}$ value can be fitted by a parabolic function with the correlation coefficient $R^{2}$ being 0.9308 . It can be accounted for the fact that the activated carbon as a kind of non-polar adsorbent has an excellent adsorption ability for non-polar dye molecules, but its adsorption property for charged ions is relatively poor. Disperse blue dye is a kind of anthraquinone dyes, containing phenolic hydroxyl, whose ionization was blocked under the condition of acidic wastewater, leading to that it exists in solution mainly in the form of molecular, so it is easier to be adsorbed on the coconut activated carbon. However, the phenolic hydroxyl group in wastewater under the strong alkaline environment is ionized into phenol of negative oxygen ions, and dissolved in water, resulting in the adsorption effect of coconut activated carbon being poor.

\section{Effect of dye concentration}

The effects of adsorption and decolorizaion for cocoanut activated carbon of 45-mesh size under different simulated dye concentrations $(10 \mathrm{mg} / \mathrm{L}$, $30 \mathrm{mg} / \mathrm{L}, 50 \mathrm{mg} / \mathrm{L}, 70 \mathrm{mg} / \mathrm{L}, 80 \mathrm{mg} / \mathrm{L}$ and $100 \mathrm{mg} / \mathrm{L})$ in wastewater with $\mathrm{pH} 5.4$ were given in figure 6 . The simulated dye wastewater was treated with the activated carbon under the conditions of adsorption temperature $25^{\circ} \mathrm{C}$ and adsorption time $10 \mathrm{~min}$. Figure 6 shows that the adsorption decolorization rate of cocoanut activated carbon decreases with the increase of the concentration of disperse dyes in simulated wastewater. Their relationship can be fitted by the exponential function (correlation coefficient $R^{2}=0.9287$ ). The reason of this phenomenon is that the adsorption capacity of activated carbon per unit mass is limited, resulting in that the concentration of residual dye in wastewater is higher when the dye concentration increases, which makes the decolorization rate of activated carbon lower. Therefore, if we want to make the dye wastewater meet with reasonable emissions requirements, the saturated adsorption capacity of the cocoanut activated carbon should be taken consideration.

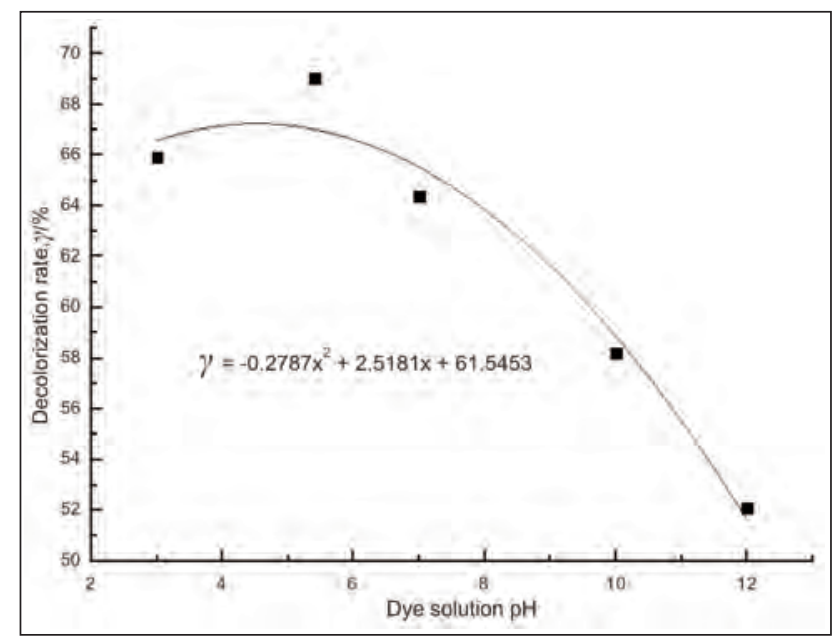

Fig. 5. Effects of dye solution pH on the decolourization ratio of cocoanut activated carbon

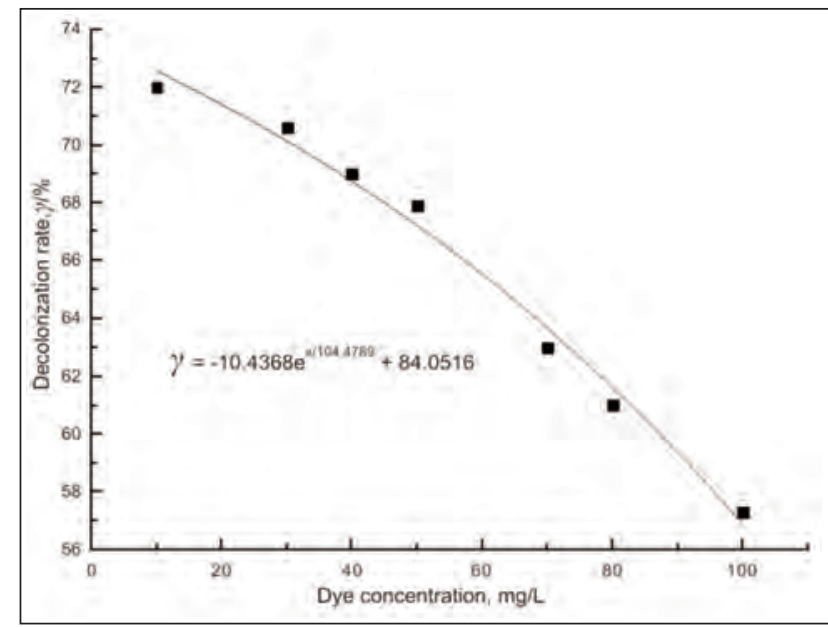

Fig. 6. Effects of dye concentration on the decolourization ratio of cocoanut activated carbon

\section{Effect of dye molecular structure}

The effect of adsorption and decolorization of cocoanut activated carbon with 45-mesh size for different molecular structures of the dye was compared, as shown in figure 7 . The disperse dye in simulated

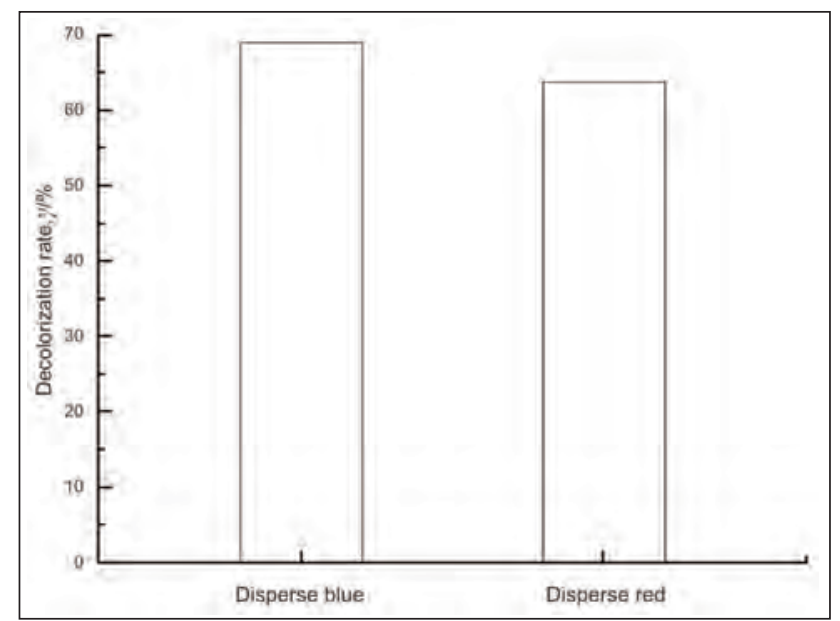

Fig. 7. Effects of dye molecular structure on the decolourization rate of cocoanut activated carbon 
wastewater with $\mathrm{pH} 5.4$ was treated with the activated carbon under the conditions of adsorption temperature $25^{\circ} \mathrm{C}$ and adsorption time $10 \mathrm{~min}$. We can see from figure 6 that compared with adsorbing disperse red dye wastewater, the effect of adsorption and decolourization of cocoanut activated carbon for disperse blue dye waste water is superior. This phenomenon is explained by the fact that disperse red dye molecules and its intermediates contain a large number of polar groups, increasing its water solubility, while aromatic groups of disperse blue dye with low biodegradability cannot be damaged easily in the weak acidic conditions, so adsorbent properties of activated carbon for non-polar molecules are superior to polar molecules, due to the activated carbon being non-polar, leading to that the decolourization rate of activated carbon for azo dye (disperse red) is lower than anthraquinone dye (disperse blue). Therefore the influence of dye with different structures of on the adsorption and decolorization of activated carbon is helpful to make full use of the properties of activated carbon and improve its effect of adsorption and decolorization.

\section{CONCLUSIONS}

Based on the simulated disperse dye wastewater, the decolorization effect of cocoanut activated carbon was studied and analyzed. The cocoanut activated carbon has a good adsorption and decolorization ability for the simulated disperse dye wastewater, which is affected by the mesh size of the cocoanut activated carbon, adsorption temperature, adsorption time, wastewater $\mathrm{pH}$ value, disperse dye concentration, and disperse dye structure.

The cocoanut activated carbon with larger mesh size has a better effect of adsorbing and decolorizing for disperse dye wastewater. The decolorization effect of cocoanut activated carbon on the adsorption of disperse dye molecules increases with the increasing of adsorption temperature, but the decoloring rate of cocoanut activated carbon affected by the adsorption temperature increases slowly. When the adsorption time varies from $5 \mathrm{~min}$ to $25 \mathrm{~min}$, the decoloring effect of cocoanut activated carbon on disperse dye wastewater upgrades quickly, and then increases slowly. Compared with the strong alkaline environment of wastewater, higher adsorption and decolorization of coconut activated carbon for disperse dye wastewater was found in the weak acid environment. The effect of adsorption and decolorization of cocoanut activated carbon get worse when the disperse dye concentration is higher in the simulated wastewater. Comparing the effect of dye molecular structure on the decolorization of cocoanut activated carbon, it can be found that the activated carbon has poor adsorbing and decoloring effect for the disperse dye wastewater containing dye with a large amount of polar groups.

\section{ACKNOWLEDGEMENTS}

The author acknowledges the research grant provided by Public Welfare Technology Application Research Project of Zhejiang province (No. 2015C33039).

\section{BIBLIOGRAPHY}

[1] Moga, I.C., Pricop, F., Iordanescu, M., Scarlat, R., Dorogan, A. Quality monitoring for wastewater generated by the textile finishing. In: Industria Textila, 2013, vol. 64, issue 4, pp. 222-228.

[2] Arora, S., Saini, H.S., Singh, K. Decolorisation of a monoazo disperse dye with Candida tropicalis. In: Coloration Technology, 2005, vol. 121, issue 6, pp. 298-303.

[3] Pourbabaee, A.A., Malekzadeh, F., Sarbolouki, M.N., Najafi, F. Aerobic decolorization and detoxification of a disperse dye in textile effluent by a new isolate of Bacillus sp. In: Biotechnology and Bioengineering, 2006, vol. 93, issue 4, pp. 631-635.

[4] Arora, S., Saini, H.S., Singh, K. Decolorisation optimisation of a monoazo disperse dye with Bacillus firmus. Identification of a degradation product. In: Coloration Technology, 2007, vol. 123, issue 3, pp.184-190

[5] Carneiro, P.A., Oliveira, D.P., Umbuzeiro, G.A., Zanoni, M.V.B. Mutagenic activity removal of selected disperse dye by photoeletrocatalytic treatment. In: Journal of Applied Electrochemistry, 2010, vol. 40, issue 3, pp. 485-492.

[6] Kurade, M.B., Waghmode, T.R., Kagalkar, A.N., Govindwar, S.P. Decolorization of textile industry effluent containing disperse dye Scarlet RR by a newly developed bacterial-yeast consortium BL-GG. In: Chemical Engineering Journal, 2012, vol. 184, issue 3, pp. 33-41.

[7] Sirianuntapiboon, S., Srisornsak, P. Removal of disperse dyes from textile wastewater using bio-sludge. In: Bioresource technology, 2007, vol. 98, issue 5, pp. 1057-1066.

[8] Paschoal, F.M.M., Anderson, M.A., Zanoni, M.V.B. The photoelectrocatalytic oxidative treatment of textile wastewater containing disperse dyes. In: Desalination, 2009, vol. 249, issue 3, pp. 1350-1355.

[9] Merzouk, B., Gourich, B., Madani, K., Vial, C., Sekki, A. Removal of a disperse red dye from synthetic wastewater by chemical coagulation and continuous electrocoagulation. A comparative study. In: Desalination, 2011, vol. 272, issue 1, pp. 246-253.

[10] Ma, H.R., Ren, J., Wang, B.H. Pilot scale study on dyeing wastewater treatment with coagulatiOn/catalytic oxidation/hydrolytic acidification/biological contact oxidation. In: Environment pollution and control, 2009, vol. 31, issue 1, pp. 39-43 (in Chinese). 
[11] Liu, E.H., Wang, J.F., We, I.F. Pilot-scale study on the treatment of wastewater containing disperse dyes with tubular ultra filtration membrane and nanofiltration. In: Technology of water treatment, 2015, vol. 41, issue 2, pp. 96-99 (in Chinese).

[12] Ahmad, A.A., Hameed, B.H. Effect of preparation conditions of activated carbon from bamboo waste for real textile wastewater. In: Journal of Hazardous Materials, 2010, vol. 173, issue 1-3, pp. 487-493.

[13] Gerçel, Özgül, Gerçel, H.F., Koparal, A.S., Öğütveren, Ülker. Bakır. Removal of disperse dye from aqueous solution by novel adsorbent prepared from biomass plant material. In: Journal of Hazardous Materials, 2008, vol. 160, issue 2-3, pp. 668-674.

[14] Ahmad, A.A., Hameed, B.H., Ahmad, A.L. Removal of disperse dye from aqueous solution using waste-derived activated carbon: optimization study. In: Journal of Hazardous Materials, 2009, vol. 170, issue 2-3, pp. 612-619.

[15] Lu, N., Li, J., Wang, X.X., Wu, Y. Application of double-dielectric barrier discharge plasma for removal of pentachlorophenol from wastewater coupling with activated carbon adsorption and simultaneous regeneration. In: Plasma Chemistry and Plasma Processing, 2012, vol. 32, issue 1, pp. 109-121.

[16] Lan, H.F., Zou, Z.Y., Zhu, W.H., Zhi, J.W.L. Analysis of adsorption decoloring effect of granular activated carbon for simulative reactive dye wastewater. In: Journal of Textile Research, 2013, vol. 34, issue 5, pp. 70-75 (in Chinese).

[17] Tang, Q.W., Sun, X.B., Huang, S.Y., Zhu, X.Y. Study on adsorption and regeneration of activated carbon for waste with low concentration of N,N-dimethyl formamide. In: Chemical World, 2016, vol. 11, pp. 703-706 (in Chinese).

\section{Authors:}

\section{LIN-LIN YAN}

Key Laboratory of Clean Dyeing and Finishing Technology of Zhejiang Province

Shaoxing University

Shaoxing 312000 , P. R. China

Key Lab of Textile Science \& Technology, Ministry of Education

DongHua University

Shanghai, 201620, P. R. China

\section{LIN-MIN ZHU}

ZHUAN-YONG ZOU

Key Laboratory of Clean Dyeing and Finishing Technology of Zhejiang Province Shaoxing University

No. 508 west Huancheng Road, Shaoxing 312000, P. R. China

\section{LIAN-YIN ZHAO \\ JIAN-DI ZHOU \\ DANG-PING ZHU}

Zhejiang Province New Textile Research \& Development Emphasised Laboratory Zhejiang Textile \& Garment Science \& Technology Co., Ltd.

Hangzhou 310009, P. R. China

\section{Corresponding author:}

ZHUAN-YONG ZOU

e-mail: HYPERLINK "mailto:Iydialhf@qq.com" zouzhy@usx.edu.cn 


\title{
Research on cold plasma treatment of leather and fur based materials as ecological alternative
}

\author{
DOI: $10.35530 / I T .068 .05 .1365$
}

LILIOARA SURDU

IONEL BARBU

MIHAELA-DOINA NICULESCU

PETER DINEFF

TODORKA G. VLADKOVA

\section{REZUMAT - ABSTRACT}

\section{Cercetări privind tratamentul cu plasmă rece a materialelor din piele şi blană ca alternative ecologice}

Lucrarea prezintă performanțele pieilor şi ale blănurilor tratate în prealabil cu plasmă rece generată prin descărcare cu barieră dielectrică (DBD) la presiune atmosferică și temperatura camerei, urmată de tratarea cu materiale chimice. Principalele proprietăți îmbunătățite au fost impermeabilitate la apă și rezistență la flacără; două caracteristici importante pentru articole de îmbrăcăminte cu valoare adăugată (încălțăminte rezistentă la apă şi pentru pompieri), mobilier şi automobile de înaltă calitate cu tapiserie din piele. Rezistența la picătura de apă în condiții statice, relevă un efect hidrofob pe suprafața dermei indusă de pre-tratamentul în plasmă rece, similar celui indus de impregnarea chimică. Rezistența la apă în condiții dinamice a demonstrat reactivarea grupărilor hidrofile în materiale pe bază de colagen și cheratină, similar cu alte materiale pre-tratate cu plasmă rece, prezentate în literatura de specialitate. Cantitatea de apă, care a pătruns în derma blănurilor a scăzut cu 22,7\%, pentru probele pre-tratate cu plasmă rece și tratate cu material pe bază de silicon comparativ cu probele fară pre-tratare în plasmă. Pielea cu față naturală, pretratată cu plasmă rece, a prezentat un comportament impermeabil şi rezistență îmbunătătită la flacără. Influența pretratamentului în plasmă rece a fost favorabilă pentru impermeabilitatea la apă a pieilor, blănurilor și pentru proprietățile ignifuge a diferite tipuri de piele.

Cuvinte-cheie: plasmă rece, piele, blănuri, absorbție de apă, rezistență la flacără

\section{Research on cold plasma treatment of leather and fur based materials as ecological alternative}

The paper presents the performances of leathers and fur skins pre-treated with cold plasma through dielectric barrier discharge $(D B D)$ at atmospheric pressure and room temperature followed by treatment with chemical materials. The main improved properties were water repellency and flame resistance, two important characteristics for added value garments (water proof and fireman footwear), high quality furniture and automotive leather upholstery. The water drop resistance in static conditions reveals a hydrophobic effect on dermis surface induced by cold plasma pre-treatment, similar with chemical impregnation. The water resistance in dynamic conditions showed the reactivation of hydrophilic groups inside collagen and keratin based materials, similarly with other materials pre-treated with cold plasma presented in literature. The water quantity which penetrated the fur skins dermis decreased by $22.7 \%$ for the pretreated samples with cold plasma and treated with silicon based materials as compared to samples not pre-treated with plasma. Full grain leathers pre-treated with cold plasma showed impermeable behavior and improved flame resistance. The influence of cold plasma pre-treatment was favorable for water repellency of leathers and fur skins and for flame retardant properties of different kinds of leathers.

Keywords: cold plasma, leather, fur skins, water absorption, flame retardant properties

\section{INTRODUCTION}

Plasma treatment of textile and wood materials worldwide gained a special attention from many scientists because of the ecological effect of physical treatment as compared to chemical impregnation with the use of high quantities of chemical materials and energy [1-5].

For collagen-based material after plasma treatment the contact angle analysis revealed that the surface hydrophilicity significantly increased and AFM characterization showed an increase in surface roughness $[6,7]$. Enhanced physical characteristics, wettability due to hydrophilicity and increased contact surface due to roughness are important for accelerating the diffusion of chemical materials and the processes at the solid-liquid interface during leather and fur processing.

After $\mathrm{O}_{2} / \mathrm{H}_{2} \mathrm{O}$ low-temperature plasma treatment of natural leather the scanning electron microscopy (SEM) showed that the pores on the leather surface became deeper and larger with enhanced permeability of water and vapor [8, 9].

Surface morphology of natural leather plasma treated with diffuse coplanar surface barrier discharge (DCSBD) at atmospheric pressure was not affected but plasma treatment caused wettability change at the half value of contact angle in comparison with untreated leather [10].

Another study with positive results addresses an environmentally-friendly solution for leather dyeing 
by using atmospheric pressure non-thermal plasma to improve natural dyeing [11].

Leather and fur skin are natural materials with porous and hydrophilic characteristics and are difficult to efficiently process in hydrophobic and flame retardant products without a limited class of chemical materials such as silicon based polymers and halogenated compounds. Both ecological and economical aspects generated the need for new alternatives.

Research studies showed that low-pressure parallel plate plasma treatment improved remarkably the waterproofness of natural leather without discoloration [12].

Recent research studies showed that plasma treatment of collagen and keratin based materials [13] increases the hydrophilic groups on the surface and the reactivity for dyestuffs and fatliquors.

It is known that natural leather is used for protection footwear (firemen), furniture upholstery for homes, conference rooms, car or airplane upholstery. For this purpose they must be specially treated to meet conditions imposed by the regulations on fire protection and safety. Most chemical materials used for fireproofing leathers are based on halogens, bromides, which are applied in aqueous baths as final treatment [14]. It is known that halogenated products are toxic and are to be eliminated as a result of severe European regulations imposed on chemicals [15].

The paper presents the influence of cold plasma pretreatment of fur skins and different kinds of leathers on water repellent and flame retardant performances.

\section{EXPERIMENTAL WORK}

\section{Methods of investigation}

The plasma pre-treatment of different kinds of materials (full grain, split leathers and fur skins) was performed using a device for producing cold plasma through dielectric barrier discharge (DBD) at atmospheric pressure and room temperature $[16,17]$. The device for DBD -technological plasma generation consists of coplanar shaped rectangular electrodes with one glass barrier ( $3 \mathrm{~mm}$ thick) closely arranged to the grounded electrode (GE), with $6 \mathrm{~mm}$ operating distance between the high voltage electrode (HVE) and the barrier (DB), (figure 1). The DBD was

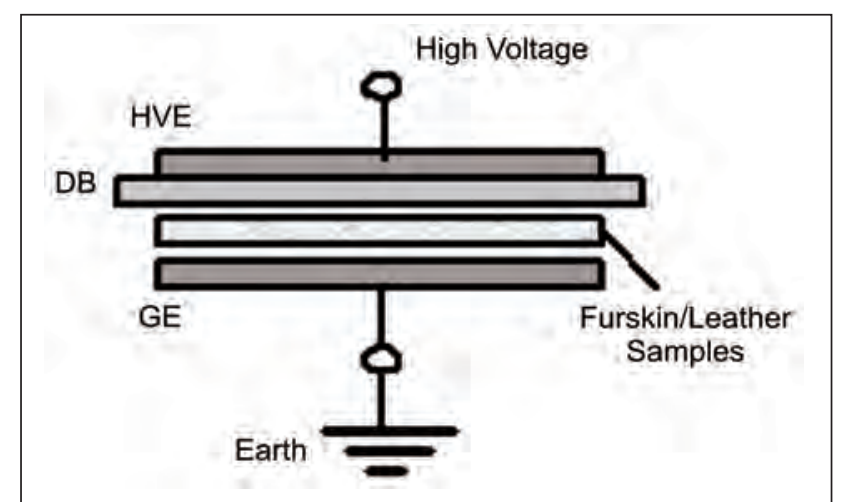

Fig. 1. Dielectric barrier air discharge (DBD) based device scheme [16] for leather and furskin pre-treatment with the mobile device ensured by a low frequency $(50 \mathrm{~Hz})$ voltage generator. The leather or fur skins samples were disposed in operating volume and were treated for 3-5 minutes under the chosen operational regime.

The plasma pre-treatment creates the necessary polar functional groups in collagen or keratin based material, which improves adhesion and wettability properties or closes the surface pores with hydrophobic effect similar to chemical impregnation.

In order to compare the best regime for plasma pretreatment, the furskins were treated with cold plasma for 3 minutes at $16 \mathrm{kV} / 400 \mathrm{~mA}$ (samples P1 and P3) and with cold plasma in ozone atmosphere for $5 \mathrm{~min}$ utes at $14 \mathrm{kV} / 2 \mathrm{~mA} / 0.7 \mathrm{ml} \cdot \mathrm{min}^{-1} / 20 \mathrm{~mm}$ (samples P2 and P4).

The hydrophobising treatment was carried out by spraying of samples with the same quantity of a silicon fatliquor based product (Densodrin CD, BASF). The pre-treated and non pre-treated samples with cold plasma and treated with silicon based materials were analyzed in terms of their resistance to water drop (ISO 15700:1998), water absorption ability and water quantity penetrated through dermis (EN ISO 5403:2003). The water absorption was tested after 2 hours and 24 hours of immersion and in dynamic conditions on fur skins and leathers processed by using conventional technologies based on chromium salts or ecological technologies based or organic tanning materials.

The experiments to improve flame retardancy properties by using cold plasma pre-treatment were similarly carried out with a halogen free chemical product based on a phosphorous and nitrogen material with $30 \%$ wt content, $\mathrm{pH}=7-8$ and density of $1.15 \mathrm{~g} / \mathrm{cm}^{3}$ [14]. Replacing bromine-based flame retardants materials with halogen free compounds represents an ecological step forward in agreement with IPPC European Directive [18]. The flame resistance of full grain and split leathers was tested according to SR EN ISO 15025:2003.

\section{RESULTS AND DISCUSSIONS}

The pre-treatment of furskin surface with cold plasma in view of hydrophobising chemical treatment

The evaluation of ecological furskins (tanned with glutaraldehyde) pre-treated with cold plasma (P1) and cold plasma in ozone atmosphere (P2), as compared to control (untreated) sample showed that the time for water drop penetration was longer for cold plasma pre-treated furskins and the longest time as compared to cold plasma in ozone atmosphere (figure 2). The chromium tanned fur skins (P3 and P4) showed a similar behavior, as seen in figure 3 . Chromium tanned fur skins have more repellent character (time of water drop penetration of $315 \mathrm{sec}$ ) as compared to ecological furskins (time of water drop penetration of $180 \mathrm{sec}$ ) in initial state, before pretreatment. The higher hydrophilic characteristics of ecological fur skins can be explained by closer distances of collagen fibers in organic tanned fur skins. The hydrophobic effect of cold plasma pre-treatment 


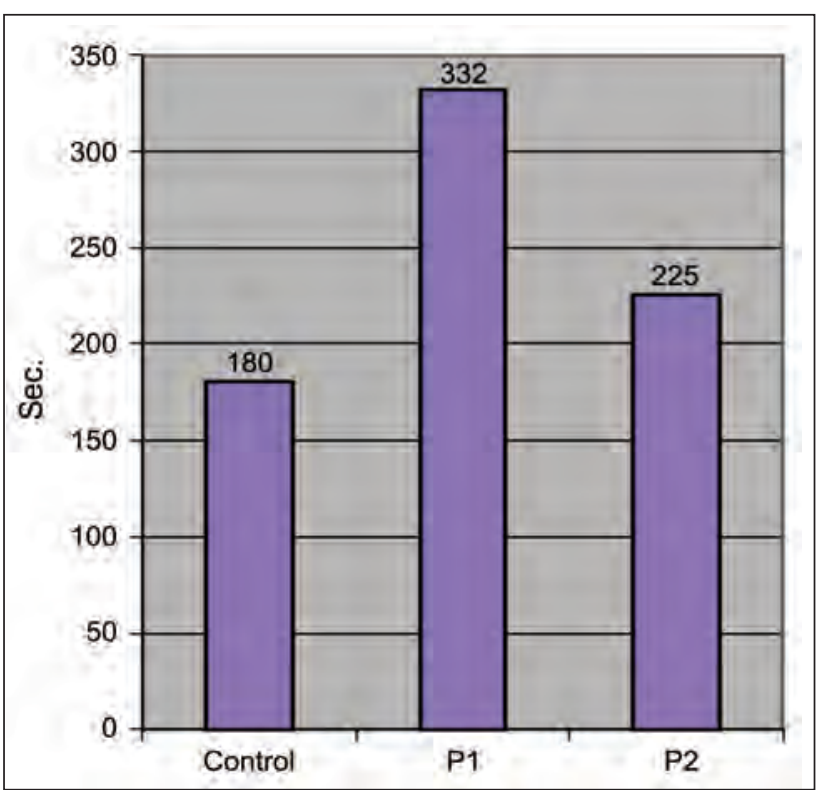

Fig. 2. The penetration time of water drop in dermal layer of ecological furskins

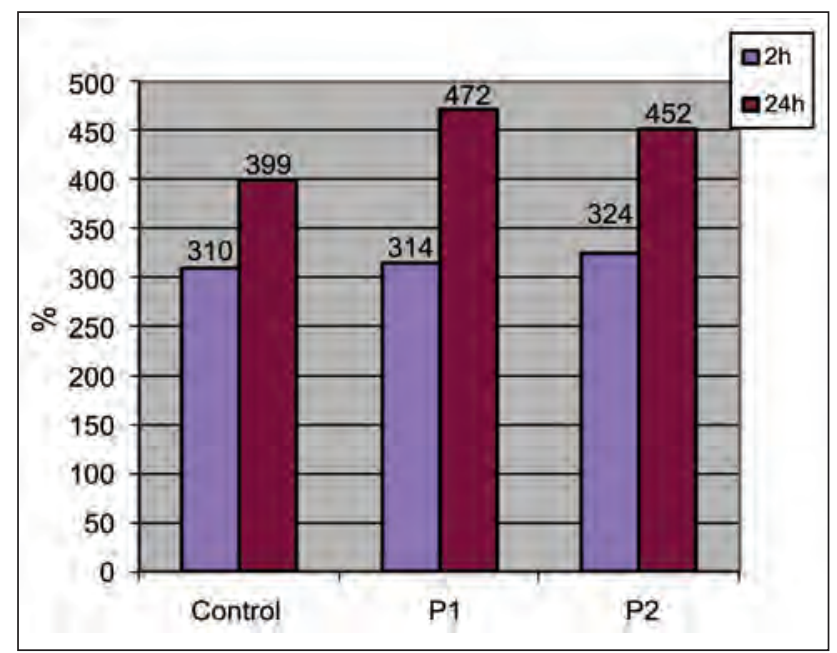

Fig. 4. The water absorption after $2 \mathrm{~h}$ and $24 \mathrm{~h}$ of immersion of ecological furskins

was higher for ecological furskins (152 sec increase as compared to initial state) as compared to chromium tanned furskins (110 sec increase as compared to initial state). The influence of ozone atmosphere was higher for chrome tanned furskins (80 sec increase time) as compared to ecological furskins (45 sec increase time). We assumed that the plasma pretreatment had the effect of classical chemical impregnation of very permeable reticular layer of furskins surface with closing of dermal pores. The effect can have significant economical and ecological importance for different finishing processes of furskin surface (as is nappalan finishing).

The analyses of water absorption of the same furskins samples showed that the hydrophobising effect was only at the furskin surface, inside of furskins structure the hydrophilic groups were reactivated and the effect was higher for chromium tanned furskins after 2 hours of immersion and after 24 hours of immersion for ecological furskins (figures 4 and 5).

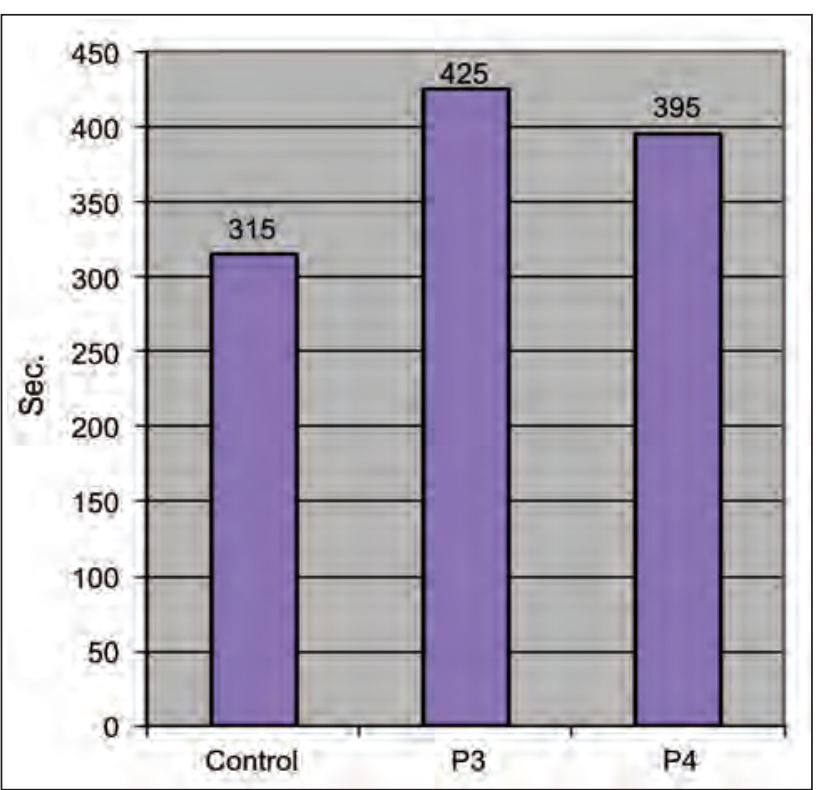

Fig. 3. The penetration time of water drop in dermal layer of classical furskins

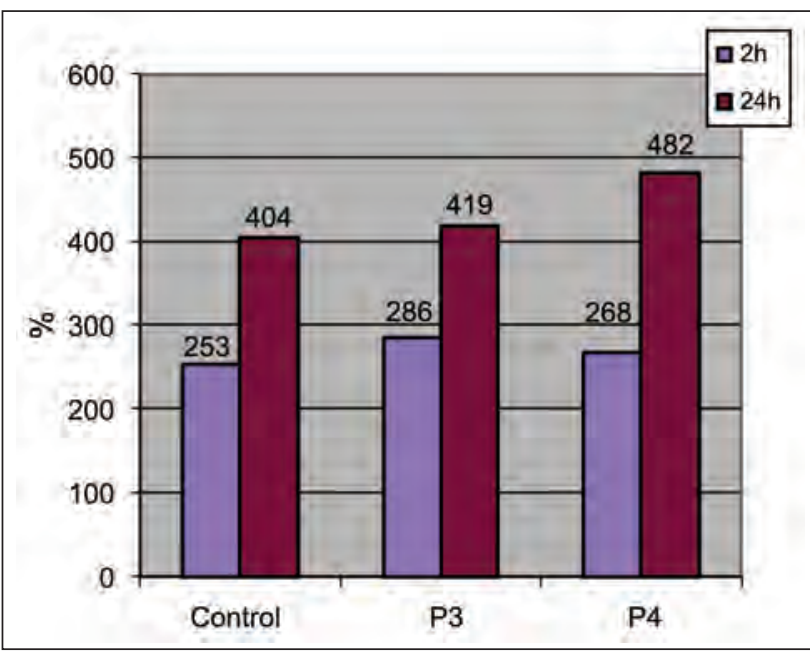

Fig. 5. The water absorption after $2 \mathrm{~h}$ and $24 \mathrm{~h}$ of immersion of classical furskins

The results suggest that it is possible to reduce the wetting chemical materials at furskins dyeing or other wet finishing processes and the higher affinity of collagen and keratin for chemical materials can have as effect exhausted effluents. The generation of hydrophilic groups inside leather and furskins under cold treatment is in agreement with literature data $[19,20]$.

An improvement of hydrophobic properties after silicon based treatment showed that the samples pretreated with cold plasma (BDP) are more hydrophobic as compared to samples without pre-treatment and the water absorption was 18\% lower after 24 hours of immersion (figure 6).

The behavior of fur skins in dynamic conditions of interaction with water expressed an increased time of water penetration (figure 7) and a remarkable decrease of water absorption after 1 hour (figure 8); the water quantity which penetrated the fur skins dermis decreased by $22.7 \%$ for the samples pre-treated 


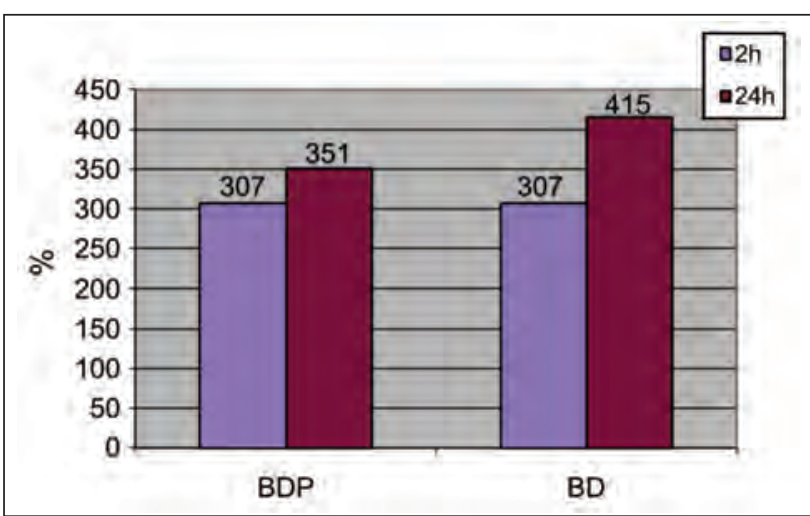

Fig. 6. The water absorption of pre-treated furskins with cold plasma and treated with silicon based materials (BDP) as compared to furskins without pre-treatment (BD)

with plasma and treated with silicon based materials (figure 9).

The hydrophobising effects were recorded for different kinds of finished leathers pre-treated with cold plasma (LDP and LBDP) as compared with samples without plasma pre-treatment (LD and LBD) and treated with silicon based materials. The time of water drop penetration in leather surface in static conditions increased by $21 \%$ (LDP sample) and by $50 \%$ (LBDP sample), respectively (figure 10).
The evaluation of full grain leathers in dynamic conditions of interaction with water proved an impermeable behaviour due to the cold plasma pre-treatment (figures 11 and 12).

The same improvements were obtained for split leathers (SWDP, SDP), the most sensitive leathers to water contact (figure 13).

The ecological leathers showed the same behavior (not presented), the time of water drop penetration decreased for the pre-treated leathers with cold plasma as compared to the un pre-treated samples.

\section{Flame retardant treatment of leathers by using cold plasma pre-treatment}

The results of flame resistance test of different leathers (full grain, split chromium tanned leathers and ecological leathers) treated with flame retardant material based on phosphorous and nitrogen compounds demonstrated the influence of cold plasma pre-treatment as compared to un pre-treated and untreated samples. Figure 14 shows the resistance of split leathers to flame exposure and table 1 the images and the behavior of different leathers after flame test. Cold plasma pre-treatment improved the surface resistance to flame, the surfaces were less wrinkled and less carbonized as compared to un pretreated and untreated leathers.

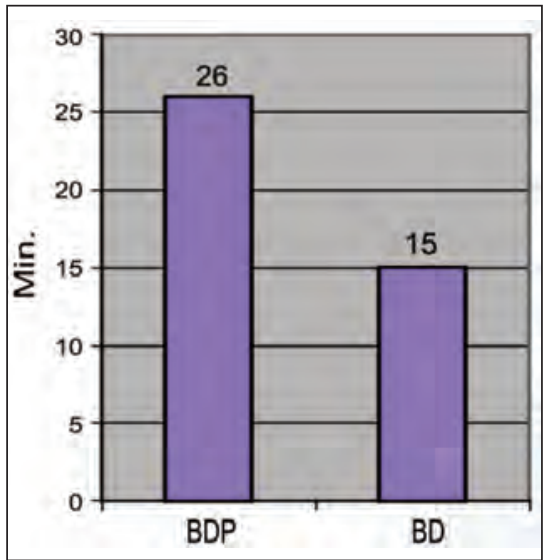

Fig. 7. Time of water penetration in dynamic condition

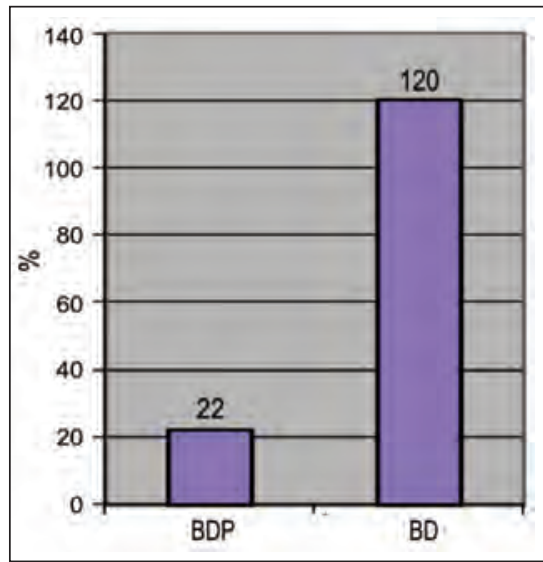

Fig. 8. Water absorption in dynamic conditions

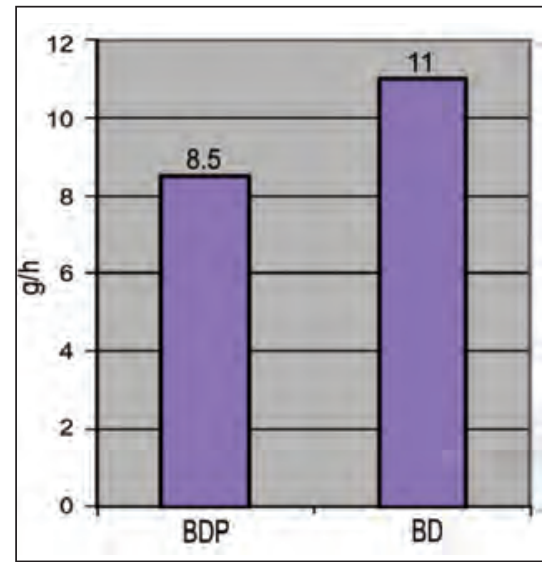

Fig. 9. Water quantity which penetrated the dermis

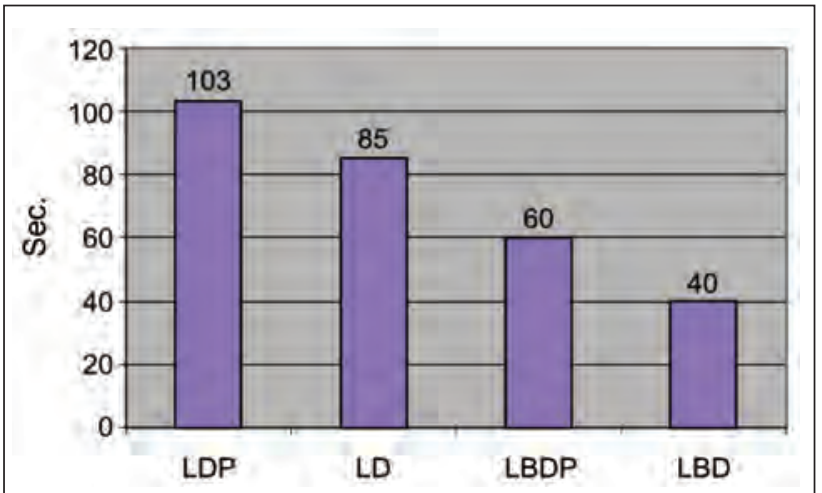

Fig. 10. Time of water penetration in static conditions on full grain leathers pre-treated with cold plasma (LDP and LBDP) as compared to leathers without plasma pre-treatment (LD and LBD)

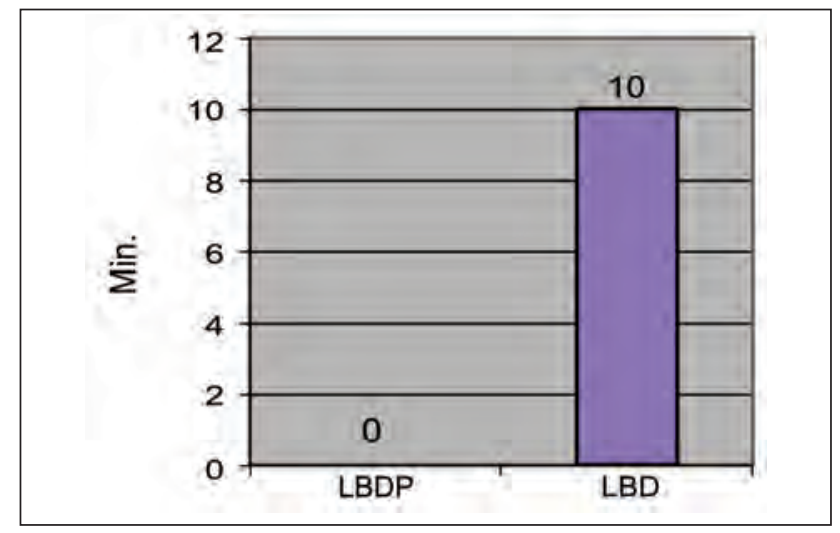

Fig. 11. Time of water penetration in dynamic conditions in full grain leathers: pre-treated (LBDP) and unpre-treated leathers (LBD) with cold plasma 


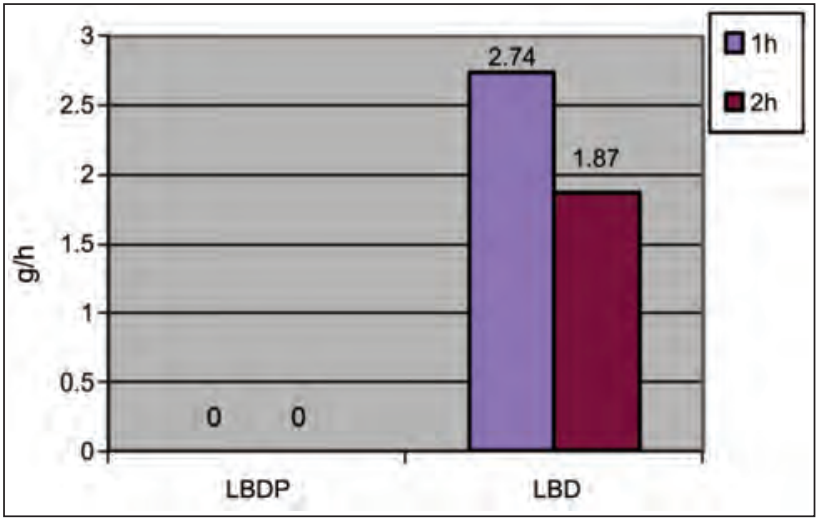

Fig. 12. Water quantity penetrated through pre-treated (LBDP) and un pre-treated (LBD) with cold plasma after $1 \mathrm{~h}$ and $2 \mathrm{~h}$

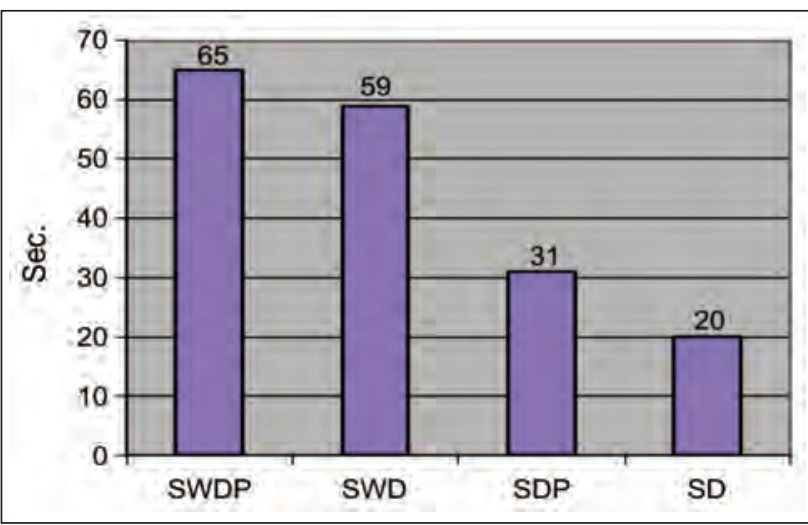

Fig. 13. Time of water penetration in static conditions for split leathers pre-treated with cold plasma (SWDP, SDP) as compared to samples without pre-treatment (SWD, SD)

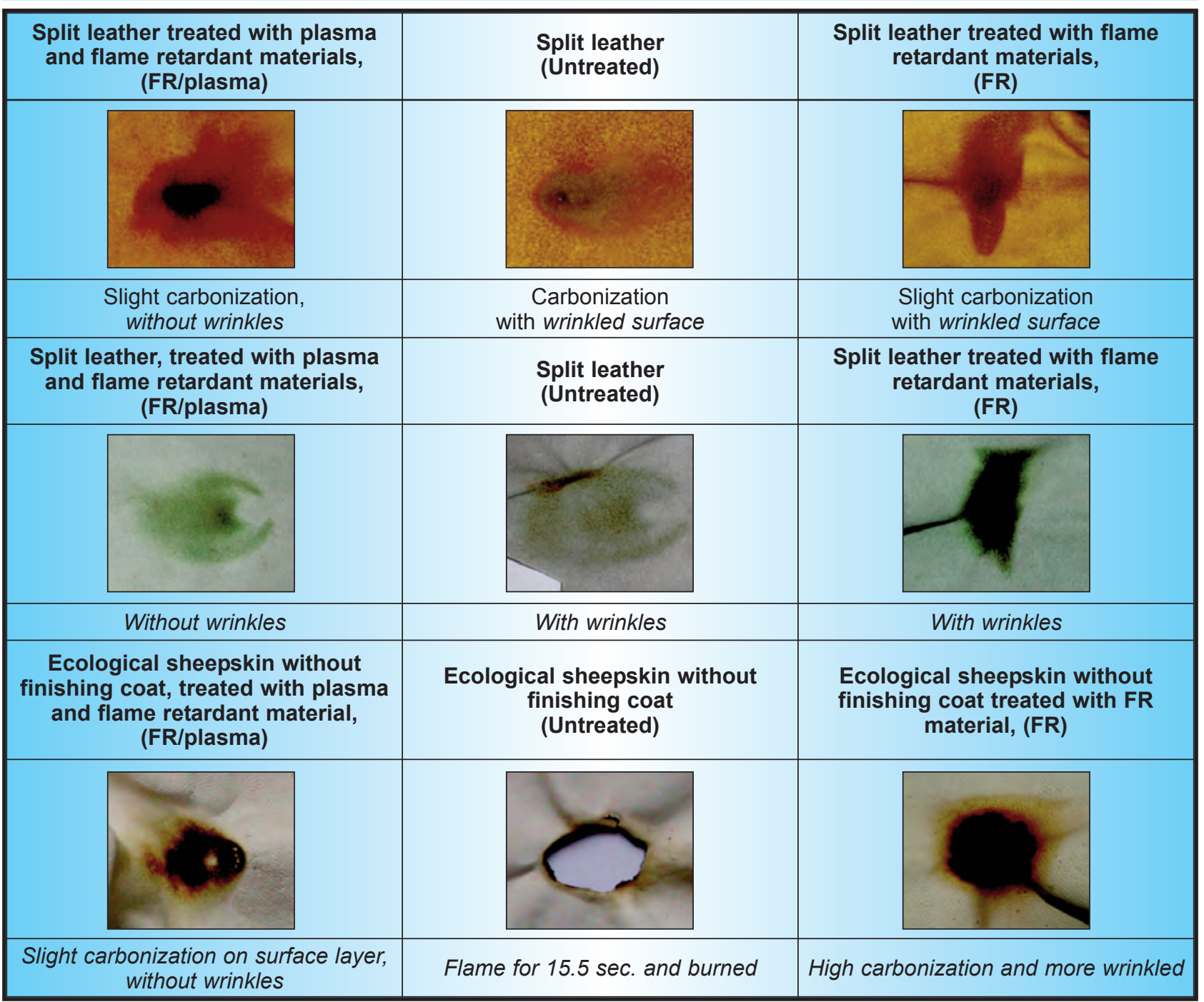

Flame resistance test according to SR EN ISO 15025:2016 for different kinds of leathers, pre-treated with cold plasma as compared to un pre-treated and non treated leathers are presented in table 1.

The results of experiments on cold plasma pre-treatment of leather and furskins are original and open the way to new applications with favourable ecological and economical impact.

\section{CONCLUSION}

Cold plasma generated by dielectric barrier discharge (DBD) at atmospheric pressure and room temperature is a promising technique for dry reactivation and physical modification of collagen and keratin based materials with the prospect of improving complex characteristics such as water repellency and flame retardancy. The hydrophobic and fire resistant 


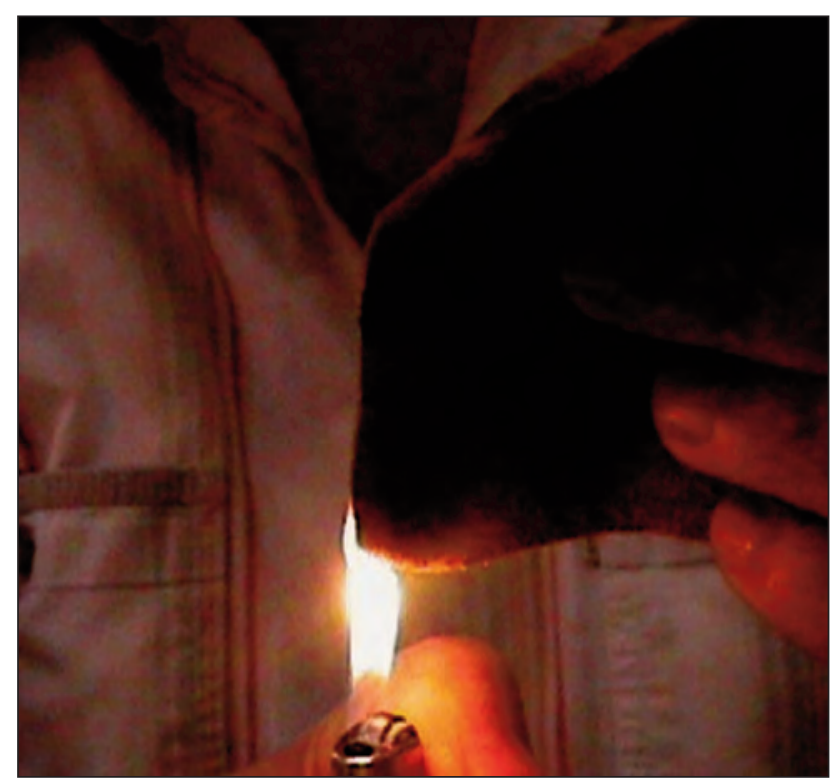

Fig. 14. Split leather exposed to flame materials are added value products for protective footwear, automotive and furniture leathers manufacture and their production involves expensive and pollutant chemicals. The pre-treatment of collagen and keratin based materials with cold plasma showed to have a superficial effect of hydrophobising, similar to chemical impregnation and a hydrophilic effect in bulk material. The water repellency in static and dynamic conditions of fur skins and leathers pretreated with cold plasma was clearly demonstrated as compared to samples without cold plasma pretreatment. Leather samples pre-treated with cold plasma and treated with flame retardant materials showed improved behavior to flame test.

The experiments on cold plasma application in leather and fur skins processing suggested the possibility to reduce the use of pollutant chemicals.

\section{ACKNOWLEDGEMENTS}

The works were supported by the Romanian National Authority for Scientific Research, CNDI-UEFISCDI, project number 314E under the Eureka project, E!5770 BIOFUR.

\section{BIBLIOGRAPHY}

[1] Jelil, R. Abd. A review of low-temperature plasma treatment of textile materials, In: Journal of Materials Science, 2015, 50(18), pp. 5913-5943.

[2] Alam, R., Hossain, G., Grabher, G., Hossain, M. Applications of low pressure plasma in high-tech textiles, In: $13^{\text {th }}$ International Conference on Plasma Surface Engineering, September 10-14, 2012, in Garmisch-Partenkirchen, Germany, pp. 247-250.

[3] Surdu, L., Surdu, I., Radulescu, I. R. Research for accomplishing multifunctional textiles with plasma technology, In: Industria Textila, 2016, 67(5), pp. 314-321.

[4] Niculescu, C., Ghituleasa, C., Dumitrescu, I., Mocioiu, A., Piticescu. R., Petriceanu, M., Bogdanescu, C., Sobetkii, A., Selva, C.S. Nanoparticles and deposition method for photocatalytic textiles and durable wood, In: $5^{\text {th }}$ International Conference on Advanced Materials and Systems, 2014, pp. 91-96.

[5] Surdu, L., Radulescu, I.R., Barbu, I. Life cycle assessment for medical textiles treated with plasma, In: Industria Textila, 2015, 66(6), pp. 360-364.

[6] Rafat, M., Griffith, M., Hakim, M., Muzakare, L., Li, F., Khulbe, K.C., Matsuura, T. Plasma surface modification and characterization of collagen-based artificial cornea for enhanced epithelialization, In: Journal of Applied Polymer Science, 2007, 106(3), pp. 2056-2064.

[7] Duan, Y., Wang, Z., Yan, W., Wang, S., Zhang, S., Jia, J. Preparation of collagen-coated electrospun nanofibers by remote plasma treatment and their biological properties, In: J. Biomater. Sci. Polym. 200, 18(9), pp. 1153-1164.

[8] You, X., Gou, L., Tong, X. Improvement in surface hydrophilicity and resistance to deformation of natural leather through $\mathrm{O}_{2} / \mathrm{H}_{2} \mathrm{O}$ low-temperature plasma treatment, In: Applied Surface Science, 2016, 360, Part A, pp. $398-402$.

[9] Kaygusuz, M., Meyer, M., Junghans, F., Aslan, A. Modification of leather surface with atmospheric pressure plasma and nano-finishing, In: Polymer-Plastics Technology and Engineering, 2017, online.

[10] Štěpánová, V., Kelar, J., Slavíček, P., Chlupová, S., Jurmanová, J., Stupavská, M., Zvonař, M., Černák, M. Plasma treatment of natural leather with diffuse coplanar surface barrier discharge in ambient air, In: Proceedings of International Symposium on High Pressure Low Temperature Plasma Chemistry, Brno Masaryk University, 2016, pp. 330-333, ISBN 978-80-210-8318-9.

[11] Dave, H., Ledwani, L., Nema, S.K., Improvement in natural dyeing with the aid of atmospheric pressure plasma treatment: a green solution for leather processing, In: Current Environmental Engineering, 2017, 4, online.

[12] Choi, J.H., Lee, E.S., Baik, H.K., Lee, S.-J., K Song, K.M., Hwang, M.K., Huh, C.S. Surface modification of natural leather using low-pressure parallel plate plasma, In: Surface and Coatings Technology, 2003, 171(1-3), pp. 257-263.

[13] Gaidau C., Niculescu M., Surdu L., Dinca L. Plasma treatment of wool on sheepskin as ecological technology alternative, In: International Scientific Conference "Advanced polymer materials and technologies" October 22-23, 2015 Kyiv, KNUTD, pp. 449-452.

[14] Gaidau, C.C., Simion, D., Vladkova, T.G., Dineff, P.D., Nikolova, D.N. Metoda si articole de piele si blana natural prelucrate prin modificarea suprafetei cu plasma rece, In: RO 128932 A2 2013.

[15] Regulation (EC) No 1907/2006 - REACHconcerning the Registration, Evaluation, Authorisation and Restriction of Chemicals (REACH) and establishing a European Chemicals Agency 
[16] Dineff, P., Kostova, L. Method for plasma chemical surface modification. In: HO5H 1/24, International Patent Publication No.: WO Patent 2006/133524 A2: International Patent Application No.: PCT/BG2006/000012; Priority Date:14: 14.06.2005 (109189); Publication Date:21.12.2006

[17] Dineff, P., Gospodinova, D., Avramova, I., Vladkova, T., Gaidau, C. Investigation on dielectric barrier discharge surface activation effect, In: Proceedings of Technical University of Sofia, 2011, vol. 61, no. 2, pp. 77-85.

[18] Best Available Techniques (BAT) Reference Document for the Tanning of Hides and Skins, In: Industrial Emissions Directive 2010/75/EU (Integrated Pollution Prevention and Control), 2013, http://eippcb.jrc.ec.europa.eu/ reference/BREF/TAN_Adopted552013.pdf.

[19] Karahan, H. A., Özdoğan, E. Improvements of surface functionality of cotton fibers by atmospheric plasma treatment, In: Fibers and Polymers, 2008, 9(1), pp. 21-26.

[20] Mercado-Cabrera, A., Jaramillo-Sierra, B., López-Callejas, R., Valencia-Alvarado, R., de la Piedad-Beneitez, A., Peña-Eguiluz, R., Barocio-Delgado, S., Muñoz-Castro, A., Rodríguez-Méndez, B. Surface modification of polypropylene fiber for hydrophilicity enhancement aided by DBD plasma, In: Progress in Organic Coatings, 2013,76(12), pp. 1858-1862.

\section{Authors: \\ CARMEN GAIDAU 1 \\ MIHAELA NICULESCU ${ }^{1}$ \\ LILIOARA SURDU² \\ IONEL BARBU ${ }^{3}$ \\ TODORKA VLADKOVA 4 PETER DINEFF 5}

${ }^{1}$ R\&D National Institute for Textiles and Leather (INCDTP), Leather and Footwear Research Institute (ICPI) Division,

93, Ion Minulescu street, Bucharest, 031215, Romania

${ }^{2}$ R\&D National Institute for Textiles and Leather (INCDTP),

16, Lucretiu Patrascanu street, Bucharest, 030508, Romania

${ }^{3}$ Aurel Vlaicu University of Arad,

7, Revolutiei Blvd.street, Arad, 310139, Romania

${ }^{4}$ University of Chemical Technology and Metallurgy

8 St. Kliment Ohridski Blv., 1000 Sofia, Bulgaria

${ }^{5}$ Technical University of Sofia

8 St. Kliment Ohridski Blv.,1000 Sofia, Bulgaria

e-mail: carmen_gaidau@hotmail.com;mihaelaniculescu59@yahoo.com; lilioara.surdu@certex.ro; laurentiu.dinca@certex.ro; ionelbarbu@yahoo.com; dineff_pd@abv.bg

\section{Corresponding authors:}

\section{CARMEN GAIDAU}

carmen_gaidau@hotmail.com

MIHAELA NICULESCU

mihaelaniculescu59@yahoo.com

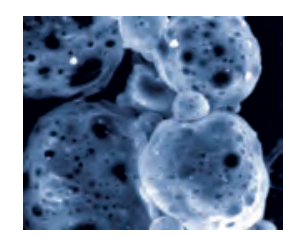




\title{
Chemical modification of linen fabrics for salt free dyeing with anionic dyes
}

\author{
RIZA ATAV
}

DOI: 10.35530/IT.068.05.1394

\section{REZUMAT - ABSTRACT}

\section{Modificarea chimică a țesăturilor de in pentru vopsirea fără săruri cu coloranți anionici}

După cum bine se cunoaște, pentru a reduce forțele de respingere ionică între fibrele celulozice având încărcătură anionică în baia de vopsire și coloranții anionici (direcți, reactivi etc.) utilizați în vopsire, este necesar să se adauge o cantitate considerabilă de sare în baia de vopsire, în special în timpul vopsirii cu coloranți reactivi. Salinitatea ridicată din apele reziduale reprezintă un pericol pentru mediu. Din acest motiv, în acest studiu, țesăturile de in au fost supuse procesului de cationizare pentru a realiza vopsirea fără săruri cu coloranți direcți și reactivi. Pentru a determina condițiile optime ale procesului de cationizare, țesăturile de in au fost tratate cu agent de cationizare pe bază de amoniu cuaternar cu poliamino-clorhidrină la diferite concentrații, valori ale pH-ului, timpi și temperaturi. Tesăturile cationizate au fost vopsite cu coloranți direcți și reactivi. Conținutul de azot (N\%), analizele în infraroșu cu transformata Fourier (FTIR) și microscopia electronică de scanare (SEM) au fost, de asemenea, realizate pentru a investiga efectele procesului de cationizare asupra structurii chimice și morfologice a fibrelor de in. Conform rezultatelor experimentale, condițiile optime pentru cationizarea țesăturilor de in sunt: $9 \%$ agent de cationizare, $\mathrm{pH} 10$ și $75^{\circ} \mathrm{C}$ timp de 45 de minute. Mai mult, s-a stabilit că eficiența culorii a fost mai mare în cazul țesăturilor de in cationizate și vopsite fără săruri, comparativ cu probele netratate și vopsite convențional.

Cuvinte-cheie: in, cationizare, vopsire fără săruri, eficiența culorii, colorant direct, colorant reactiv

\section{Chemical modification of linen fabrics for salt free dyeing with anionic dyes}

As is known, in order to reduce the ionic repulsion forces between cellulosic fibers having anionic charge in the dyebath and anionic dyestuffs (direct, reactive, etc.) used in dyeing, it is necessary to add a considerable amount of salt to the dyebath particularly during reactive dyeing. The high salinity in the wastewater is an environmental hazard. For this reason, in this study linen fabrics were subjected to cationization process in order to achieve salt free dyeing with direct and reactive dyes. In order to determine the optimum conditions of cationization process, linen fabrics were treated with polyaminochlorohydrin quaternary ammonium based cationization agent at different concentrations, $\mathrm{pH}$ values, times and temperatures. Then the cationized fabrics were dyed with direct and reactive dyes. Nitrogen content (N\%), Fourier transform infrared (FTIR) and scanning electron microscopy (SEM) analyses were also realized to investigate the effects of cationization process on chemical and morphological structure of flax fibers. According to the experimental results, the optimum conditions for cationization of linen fabrics were found to be $9 \%$ cationization agent, $\mathrm{pH} 10$ and $75^{\circ} \mathrm{C}$ for 45 minutes. Furthermore, it was determined that the color efficiency was higher in case of cationized and salt free dyed linen fabrics compared to the un-treated and conventionally dyed samples.

Key words: Linen; cationization; salt free dyeing; color efficiency; direct dye; reactive dye

\section{INTRODUCTION}

Flax is a multicellular, lustrous and very compact bast fiber with a high stiffness and excellent tensile properties [1]. Flax (Linum usitatissimum L.) is obtained from the stem of plants belonging to the family Linacea [2]. On the other hand, linen is the yarn or the fabric made from flax fibers [3]. The main chemical constituents of flax fibers are $\alpha$-cellulose, hemicellulose, lignin, pectin along with a small amount of fats, waxes, nitrogenous compounds, residual ash and natural coloring matter [4]. As compared with cotton, flax fiber has some advantages. It is stronger than cotton and it is better than cotton as a conductor of heat. On the other hand, it is less elastic than cotton and creases easily [5]. Like cotton, linen can be dyed with direct, vat and reactive dyes [6]. When cellulosic fibers come in contact with water, they produce slightly negative charge due to the ionization of hydroxyl groups. This slightly negative charge on the fiber results in repulsion of anionic dye molecules and for this reason the exhaustion and levelling of dye molecules are affected. However, the ionic repulsion factor can be offset by adding an electrolyte and hence increased dye exhaustion can be achieved [7]. In current practice, reactive dyes are predominantly used for dyeing of cotton due to their high wet fastness properties, brilliant colors and wide range of hue. However, most of the commercially available reactive dyes show low affinity to cotton, so high concentrations of sodium chloride or sodium sulfate salts (30-100 g/L) are required in the dyebath to enhance dye-fiber interactions. The need of high amounts of salt usage leads to serious environmental pollution [8]. It increases salinity of the rivers and this affects the delicate biochemistry of aquatic life [9]. For this reason over the years a number of studies on the finishing of cotton fibers have been carried out to improve their dye-uptake properties. The focus of most research was to provide cationic sites on these 
fibers for increasing their interaction with anionic dyes [10].

Many scientists have been working for a long time to increase the cotton fiber's substantivity to anionic dyes via applying pre-treatment to fiber with cationic substances [11]. In most of these studies, quaternary cationic agents which contain various reactive groups (epoxy, active halogen, ethoxylate or amino) were used [12]. With the use of epoxyamine or quaternary epoxyammonium compound, a cationic site can be introduced in cellulose through reaction of an epoxy radical in alkaline medium and, therefore, the reactivity of cellulose towards anionic dyes is modified [7]. Reviewing the literature, it can be understood that most of the studies were carried out on cotton fibers [for example: 13-20] and studies on flax fiber are limited. Although one can comment that results of these studies can be applied to linen fabric due to having identical chemical composition with cotton, flax fiber in linen fabric has different molecular and morphological structure which will largely determine the degree of modification. Therefore, modifications carried out on cotton fabric cannot be directly applied to linen fabric [21]. For this reason it is also needed to be realized some studies on linen fabrics.

Hebeish et al. investigated the factors affecting the cationization reaction with Quat-188 (3-chloro-2hydroxypropyltrimethyl ammonium chloride) of linen fabric both for the exhaustion and the cold pad-batch methods [21]. In another study, they cationized linen fabrics by using 3-chloro-2-hydroxypropyl trimethyl ammonium chloride in alkaline medium with cold pad-batch method. Then cationized linen fabrics were dyed with reactive, direct and acid dyes in the absence of salt [22].

Mashaly and Hauser cationized the linen fabric through the reaction of two different commercial cationizing agents; 3-chloro-2-hydroxypropyltrimethyl ammonium chloride and polyaminochlorohydrin quaternary ammonium salt with epoxide functionality. Then unmodified and cationized linen fabrics were dyed with four different types of fiber reactive dyes by using the cold pad-batch dyeing method [23]. In another study, they investigated the dyeability of linen fabrics with acid and direct dyes after cationization by using the 3-chloro-2-hydroxypropyltrimethyl ammonium chloride and polyhexamethlene biguanides [24]. In this study linen fabrics were subjected to the cationization process by using polyaminochlorohydrin quaternary ammonium salt with epoxide functionality (commercial name: Albafix E) by exhaustion method. In literature, there is already a cationization process by exhaustion method developed by Hebeish et al. for salt free dyeing of linen fabrics with reactive dyes. In that study, Quat-188 had been used as a cationization agent and dyeability of cationized linen fabrics had been investigated for only reactive dyes [21]. On the other hand, in this study chemical modification of linen fabrics was carried out with another cationization agent (Albafix E) and change in their dyeability after cationization process was investigated both with direct and reactive dyes. Although Mashaly and Hauser had previously used the same cationization agent in their research, they had determined the optimum conditions of cationization process for cold pad-batch method [24]. But, it will be very useful if a cationization process for linen fabric could be developed by exhaustion method. Because, in this case, it would be possible to carry out both the cationization and dyeing processes on the same equipment.

\section{EXPERIMENTAL WORK}

Bleached $100 \%$ linen plain woven fabric [24 yarns/ inch in warp (Tex 40) and 21 yarns/inch in weft (Tex 40)] with a weight per unit area $510 \mathrm{~g} / \mathrm{m}^{2}$ was used in this study. Solophenyl Red 3BL (C.I. Direct Red 80) and Remazol Blue BB (C.I. Reactive Blue 220) were kindly supplied by Hunstman and Dystar respectively. Cationization agent Albafix E, a polyaminochlorohydrin quaternary ammonium polymer, was provided by Hunstman. The chlorohydrin form of the reagent can be converted to the epoxy form in the presence of alkali [21]. The reaction is shown in figure 1.

This epoxy form has the ability of reacting with cellulose via ether formation as shown in figure 2 .

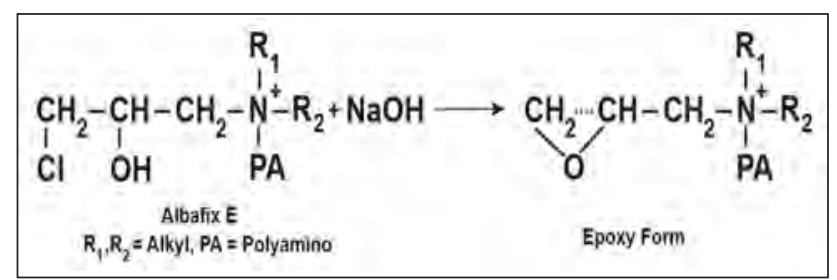

Fig. 1. Chemical structure of Albafix $E$ and its transformation to epoxy form [25]

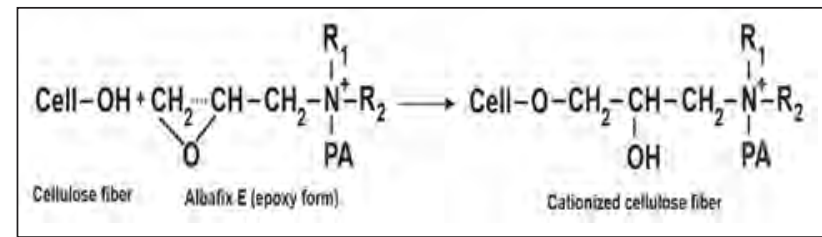

Fig. 2. Reaction between epoxy form of cationization agent (Albafix E) and cellulose

\section{Optimization}

Linen fabrics were cationized with Albafix $E$ in a laboratory scale dyeing machine (Termal HT) using exhaustion method. In order to determine the optimum conditions of cationization process, four factors potentially affecting this process were evaluated, namely cationizing agent concentration (3-6-9\%), $\mathrm{pH}$ (4-7-10), treatment time (15-30-45 min.) and treatment temperature $\left(25-50-75^{\circ} \mathrm{C}\right)$. At the end of the treatment, each sample was taken out and washed several times with cold water and dried at ambient conditions. Experiments were carried out according to the orthogonal experimental design. The orthogonal experimental design contains three levels 


\begin{tabular}{|c|l|c|c|c|}
\hline $\begin{array}{c}\text { Factor } \\
\text { symbol }\end{array}$ & \multicolumn{1}{|c|}{ Factor } & $\mathbf{1}$ & $\mathbf{2}$ & $\mathbf{3}$ \\
\hline $\mathbf{X}_{\mathbf{1}}$ & Concentration $(\%)$ & 3 & 6 & 9 \\
\hline $\mathbf{X}_{\mathbf{2}}$ & $\mathrm{pH}$ & 4 & 7 & 10 \\
\hline $\mathbf{X}_{\mathbf{3}}$ & Time (min.) & 15 & 30 & 45 \\
\hline $\mathbf{X}_{\mathbf{4}}$ & Temperature $\left({ }^{\circ} \mathrm{C}\right)$ & 25 & 50 & 75 \\
\hline
\end{tabular}

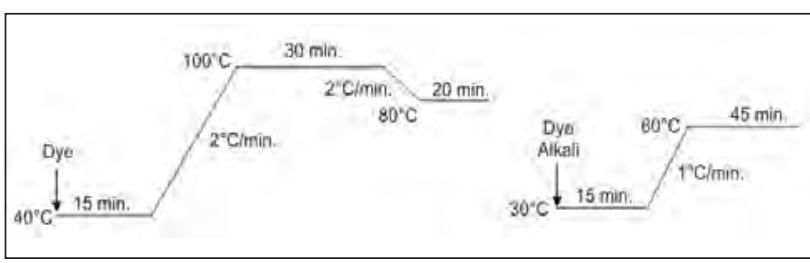

Fig. 3. Dyeing graphs for direct (on the left) and reactive dyes (on the right)

Table 2

\begin{tabular}{|c|c|c|c|c|c|c|}
\hline Trial no. & Conc. (\%) & $\mathbf{p H}$ & Time (min.) & Temp. $\left({ }^{\circ} \mathbf{C}\right)$ & $(\mathbf{K} / \mathbf{S})_{\text {direct }}$ & $(\mathbf{K} / \mathbf{S})_{\text {reactive }}$ \\
\hline 1 & 1 & 1 & 1 & 1 & 6.49 & 7.05 \\
\hline 2 & 1 & 2 & 2 & 2 & 8.88 & 8.36 \\
\hline 3 & 1 & 3 & 3 & 3 & 12.52 & 11.11 \\
\hline 4 & 2 & 1 & 2 & 3 & 8.57 & 9.34 \\
\hline 5 & 2 & 2 & 3 & 1 & 8.64 & 9.60 \\
\hline 6 & 2 & 3 & 1 & 2 & 11.23 & 10.56 \\
\hline 7 & 3 & 1 & 3 & 2 & 9.67 & 10.06 \\
\hline 8 & 3 & 2 & 1 & 3 & 10.19 & 10.11 \\
\hline 9 & 3 & 3 & 2 & 1 & 10.35 & 10.17 \\
\hline
\end{tabular}

for each factor, the coded levels and actual values being shown in table 1 .

The pattern of the levels of the each factor is shown in table 2 along with the color yield (K/S) values resulting from the individual trials.

The cationization efficiency of linen fabric was tested by using salt free dyeing. For this aim cationized linen fabrics were dyed with a direct (Solophenyl Red 3BL) and a reactive (Remazol Blue BB) dye without salt usage. After dyeing, color efficiency (K/S) values of the samples were evaluated. Higher K/S indicates higher extent of cationization and vice versa.

\section{Dyeing procedure}

After determining the optimum conditions of cationization process, linen fabrics were treated at these conditions and then dyed with a direct and a reactive dye without salt usage. All reactive dyeings were carried out by using $13 \mathrm{~g} / \mathrm{L}$ soda ash. In the conventional dyeing of un-treated samples $15 \mathrm{~g} / \mathrm{L}$ and $50 \mathrm{~g} / \mathrm{L}$ natriumsulphate salt was used for direct and reactive dyes respectively.

All dyeings were carried out in a laboratory scale dyeing machine (Termal HT) at 40:1 liquor ratio. Initial pH of dyeing was 6.5-7. Dyeing graphs for direct and reactive dyes are given in figure 3 .

After dyeing with direct dye, samples were rinsed. On the other hand, for reactive dyes washing steps were as follows: cold rinsing (10 min.) $\rightarrow$ neutralization at $60^{\circ} \mathrm{C}$ (with $0.5-1 \mathrm{~g} / \mathrm{L}$ acetic acid) $\rightarrow$ rinsing at $80^{\circ} \mathrm{C} \rightarrow$ rinsing at $95^{\circ} \mathrm{C}(15 \mathrm{~min}.) \rightarrow$ rinsing at $80^{\circ} \mathrm{C}(10 \mathrm{~min}$.) $\rightarrow$ cold rinsing. Subsequently color (both K/S and $\mathrm{CIE} L^{*} \mathrm{a}^{*} \mathrm{~b}^{*}$ values) and fastness (washing, rubbing and light) properties of these samples were compared with conventionally dyed samples.
- Color measurements: CIE L*a* $b^{*}$ ( $L^{*}$ : lightness (where $L^{*}=100$ for the perfect white and $L^{*}=0$ for the perfect black), $a^{*}$ : red $\left(+a^{*}\right)$ and green $\left(-a^{*}\right)$ coordinate, $b^{*}$ : yellow $\left(+b^{*}\right)$ and blue $\left(-b^{*}\right)$ coordinate) color values and reflectance $(\% R)$ values of the dyed samples were determined on X-Rite Color i7 reflectance spectrophotometer with illumination/ observer conditions set at $\mathrm{D} 65 / 10^{\circ}$ at the maximum absorption wavelength of each dye (540 and $620 \mathrm{~nm}$ for direct and reactive dye respectively). Then the color efficiency (K/S) was calculated from KubelkaMunk equation as shown below:

$$
K / S=(1-R)^{2} / 2 \cdot R
$$

where $R$ is the reflectance of the dyed sample, $K-$ the absorption coefficient and $S$ - the scattering coefficient. For color measurements, 3 samples were tested to compute the average value.

- Color fastness tests: The color fastnesses to washing, rubbing and light were assessed according to ISO 105-C10 [26], ISO 105-X12 [27], and ISO 105B02 [28] standard test methods respectively. Washing tests were carried out at $60^{\circ} \mathrm{C}$ for $30 \mathrm{~min}$. by using $4 \mathrm{~g} / \mathrm{L}$ ECE standard test detergent.

\section{Determination of the effects of cationization} treatment on chemical properties of linen fabrics In order to explain why dye-uptake of linen fabrics increase after cationization treatment, cationized and un-treated fabric samples were subjected to nitrogen content $(\mathrm{N} \%)$ and Fourier transform infrared (FTIR) analyses. Scanning electron microscopy (SEM) analyses were also done. On the other hand, whiteness degrees of fabrics were measured to understand better the color nuance difference between un-treated and cationized fabrics dyed at the same conditions. 
- Nitrogen content (N\%) analysis: Nitrogen content of the linen fabric before and after cationization, was determined according to Kjeldahl test method by using Gerhardt Kjeldahlterm Vaposdest test device.

- Fourier Transform Infrared Spectroscopy (FTIR) analysis: Fourier transform infrared (FTIR) spectra of cationized and un-treated samples were recorded over the range $500-4000 \mathrm{~cm}^{-1}$ on a Vertex 70 ATRFTIR Spectrometer, Bruker.

- Scanning Electron Microscopy (SEM) analysis: In order to examine the surface structure of the cationized flax fibers scanning electron microscopy (SEM) analyses were carried out. For this aim, Quanta FEG 250 scanning electron microscope (FEI, Netherland) was employed for imaging the fabric samples at 5000X and 10000X magnifications with accelerating voltage of $5 \mathrm{kV}$.

- Whiteness degree measurement: With the aim of determining the effect of cationization process on color of linen fabrics, their whiteness degrees (according to Berger) were measured prior to dyeing with Gretag Macbeth E700 spectrofotometer.

\section{RESULTS AND DISCUSSION}

\section{Results related to the optimization of the} cationization treatment

In order to determine the optimum conditions of cationization process, linen fabrics were treated with Albafix $E$ at different concentrations (3-6-9\%), $\mathrm{pH}$ values (4-7-10), times (15-30-45 min.) and temperatures $\left(25-50-75^{\circ} \mathrm{C}\right)$. Then cationized fabrics were dyed with a direct and a reactive dye. The color yields (K/S) of the cationized fabrics were taken as a measure of the extent of cationization. Results are given in figure 4 and figure 5 .

Results of analysis of variance related to the K/S values of linen fabrics dyed with direct (C.I. Direct Red 80 ) and reactive (C.I. reactive Blue 220) dye are given in table 3 and table 4 respectively.

Discussions of the results obtained are given below.

\section{- Effect of the $p H$}

As can be seen from the figures 4 and 5 , the K/S values of the cationized samples dyed with both direct and reactive dye increase as the $\mathrm{pH}$ of the cationization process increases. Furthermore it can be said that the effect of $\mathrm{pH}$ on $\mathrm{K} / \mathrm{S}$ values is statistically significant $(p<0.05)$ (table 3 and 4$)$. Improvement in the cationization degree of linen fabrics with the increase in $\mathrm{pH}$ of the reaction medium can be attributed to the necessity of alkaline medium for the formation of the epoxy group (figure 1) which is able to react with hydroxyl groups of fiber.

\section{- Effect of the temperature}

It is seen from the figures 4 and 5 that rise in the reaction temperature from $25^{\circ} \mathrm{C}$ to $75^{\circ} \mathrm{C}$ causes an increase in $\mathrm{K} / \mathrm{S}$ value. Furthermore it can be said that the effect of reaction temperature on K/S values is statistically significant $(p<0.05)$ (table 3 and 4$)$. Maximum K/S value of dyed samples is observed when the cationization treatment was carried out at $75^{\circ} \mathrm{C}$. As previously explained by Hebeish et al., the reason of this could be associated with the positive effect of the temperature on: (a) swelling of flax fiber,

\begin{tabular}{|l|c|c|c|c|c|c|}
\hline \multicolumn{1}{|c|}{ Source } & DF & Seq SS & Adj SS & Adj MS & F & Pable 3 \\
\hline Concentration & 2 & 2.9523 & 2.9523 & 1.4761 & 20.62 & 0.000 \\
\hline pH & 2 & 45.8167 & 45.8167 & 22.9083 & 319.93 & 0.000 \\
\hline Time & 2 & 5.9367 & 5.9367 & 2.9683 & 41.46 & 0.000 \\
\hline Temperature & 2 & 18.2094 & 18.2094 & 9.1047 & 127.15 & 0.000 \\
\hline Error & 18 & 1.2889 & 1.2889 & 0.0716 & & \\
\hline Total & 26 & 74.2038 & & & & \\
\hline
\end{tabular}

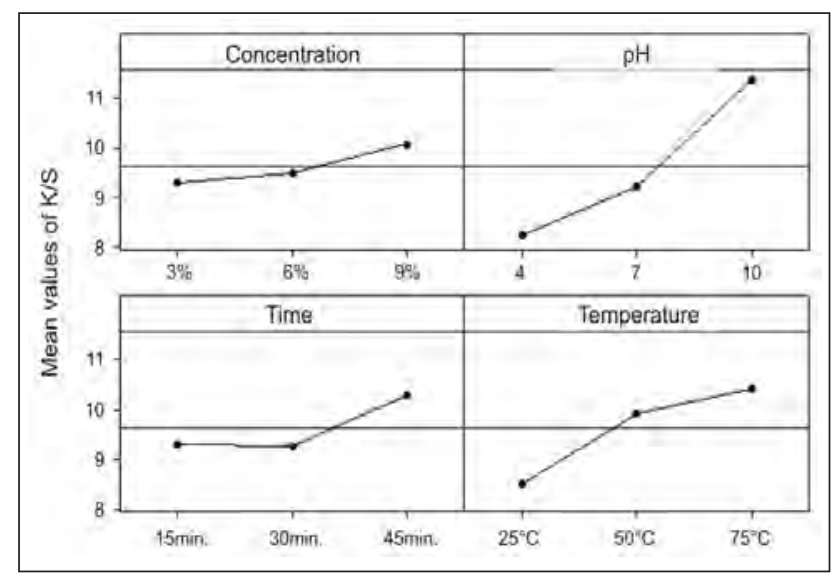

Fig. 4. Main effects plot for K/S values of linen fabrics dyed with C.I. Direct Red 80

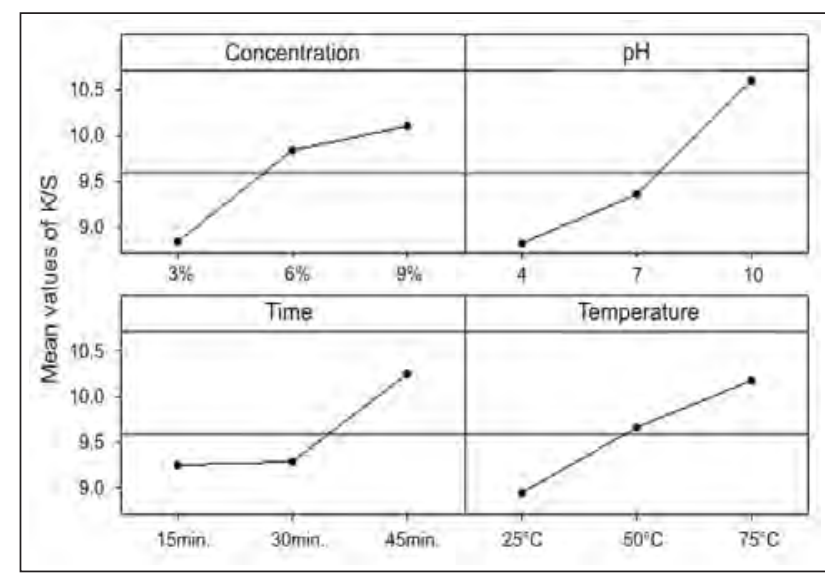

Fig. 5. Main effects plot for $\mathrm{K} / \mathrm{S}$ values of linen fabrics dyed with C.I. reactive Blue 220 


\begin{tabular}{|l|c|c|c|c|c|c|}
\hline \multicolumn{1}{|c|}{ Source } & DF & Seq SS & Adj SS & Adj MS & F & P \\
\hline Concentration & 2 & 8.0472 & 8.0472 & 4.0236 & 80.20 & 0.000 \\
\hline pH & 2 & 15.2764 & 15.2764 & 7.6382 & 152.24 & 0.000 \\
\hline Time & 2 & 5.8726 & 5.8726 & 2.9363 & 58.53 & 0.000 \\
\hline Temperature & 2 & 7.0102 & 7.0102 & 3.5051 & 69.86 & 0.000 \\
\hline Error & 18 & 0.9031 & 0.9031 & 0.0502 & & \\
\hline Total & 26 & 37.1096 & & & & \\
\hline
\end{tabular}

(b) diffusion of cationization agent, (c) compatibility of the reactants and (d) mobility of the cationization agent molecules and their probable collision with flax fiber macromolecules [21].

\section{- Effect of the duration}

It is seen from the figures 4 and 5 that when the reaction time is raised from $15 \mathrm{~min}$. to $45 \mathrm{~min}$., $\mathrm{K} / \mathrm{S}$ values were increased. Furthermore it can be said that the effect of reaction time on $\mathrm{K} / \mathrm{S}$ values is statistically significant $(p<0.05)$ (table 3 and 4 ). Maximum K/S value of dyed samples is observed when the cationization treatment was carried out for 45 minutes. As it is commonly known, for a chemical to react with a fiber there is a need of sufficient time for chemical to come in contact with fiber and to react with it. It is thought that longer time provided better opportunity for Albafix $E$ to come in contact and react with flax fiber, and therefore, better K/S values were achieved at $45 \mathrm{~min}$.

\section{- Effect of the cationization agent concentration}

It is seen from the figures 4 and 5 that rise in the cationization agent concentration from $3 \%$ to $9 \%$ increased the K/S values obtained in dyeings. Furthermore it can be said that the effect of cationization agent concentration on $\mathrm{K} / \mathrm{S}$ values is statistically significant $(p<0.05)$ (table 3 and 4$)$. As indicated before, for a chemical to react with a fiber, first it should come in contact with it. For this reason it is thought that higher cationization agent concentration increased the amount of molecules came in contact with fiber and hence higher K/S values were achieved at concentration of $9 \%$.

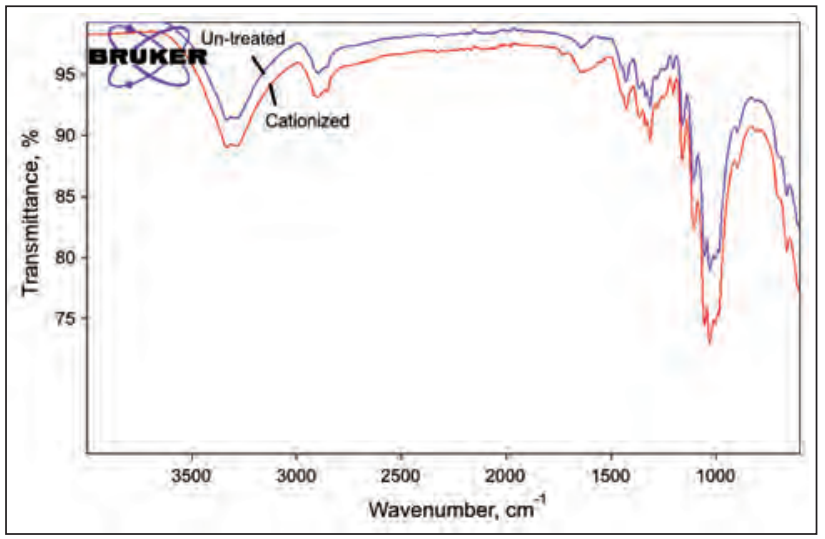

Fig. 6. FTIR spectrums of un-treated and cationized linen fabrics
Effects of cationization treatment on chemical properties of linen fabrics

Results of nitrogen content and whiteness degree analyses are listed in table 5 .

Table 5

\begin{tabular}{|l|c|c|}
\hline & Un-treated & Cationized \\
\hline Nitrogen content (N\%) & 0.34 & 0.87 \\
\hline Whiteness degree (Berger) & 47.60 & 33.39 \\
\hline
\end{tabular}

Results of Fourier transform infrared (FTIR) and scanning electron microscopy (SEM) analyses are given in figure 6 and figure 7 respectively.

Discussions of the results are given below.

\section{- Nitrogen content (N\%)}

The results given in table 5 reveal that the nitrogen content $(\mathrm{N} \%)$ of the linen fabric increased from $0.34 \%$ to $0.87 \%$ after cationization treatment which means cationization agent is added into fiber structure. The first point that should be clarified here is that also un-treated linen fabric contains $0.34 \%$ nitrogen. Flax fibers normally contain some amount of nitrogen depending on sowing conditions, climate and maturity of plant. Ahmad et al. had given range from 0.38 to 0.91 percent for nitrogen content in flax plant [29]. On the other hand, bleaching is a necessary pretreatment step subsequent to scouring before any cellulosic material is dyed and/or finished.

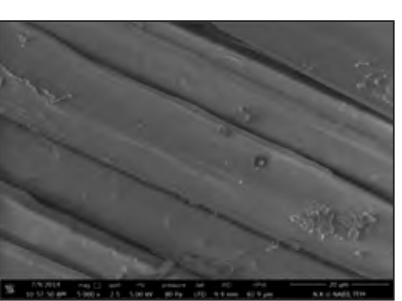

a

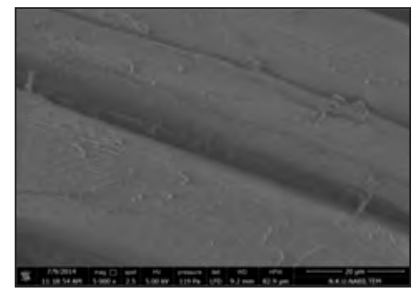

C

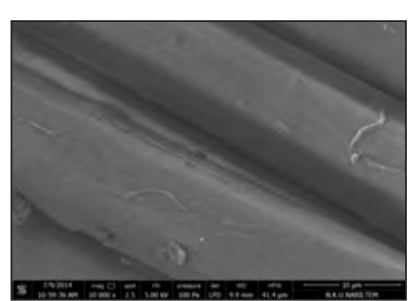

b

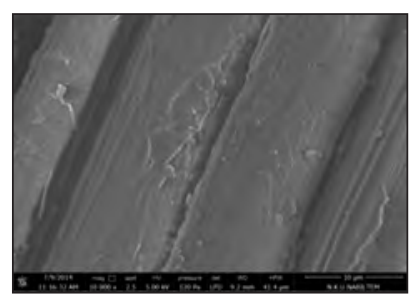

d
Fig. 7. SEM photographs of un-treated $(a$ and $b$ ) and cationized $(c$ and $d$ ) linen fabrics 
During the bleaching process natural pigments and other noncellulosic matters are removed from the fibers in some extent [30]. For this reason the nitrogen content of flax fiber is normally expected to be decreased after pretreatment processes. For example; Hebeish et al. reported the nitrogen content of scoured and bleached linen fabric as $0.25 \%$ [21].

\section{- Fourier transform infrared (FTIR) spectra}

In this study, FTIR spectra were obtained for the un-treated and cationized linen fabrics as shown in figure 7. There are certain signatures that can be assigned to specific components in the fiber. The $\mathrm{C}-\mathrm{C}$ ring breathing band at $\sim 1155 \mathrm{~cm}^{-1}$ and the $\mathrm{C}-\mathrm{O}-\mathrm{C}$ glycosidic ether band at $\sim 1105 \mathrm{~cm}^{-1}$ arise from the lignin and the polysaccharide components (that is, largely cellulose) respectively [31].

The results are very similar with the study that had been carried out on cotton fabrics with same cationization agent (Solfix $E$ which is the former commercial name of Albafix E) by Kamel et al. The broad absorption band within 3332.30 and $1028.25 \mathrm{~cm}^{-1}$ for the un-treated linen fabric corresponds to the presence of numerous hydroxyl groups. However, the (primary-OH) band of the cationized linen became a higher intensity band within 3331.24 and 1029.14 $\mathrm{cm}^{-1}$ with increasing nitrogen content of the cationized fabric. These distinct high intensity bands indicate the presence of the quaternary ammonium salts. Furthermore, two splitting distinct bands can be observed in the spectrum of cationized linen fabric within 2897.84 and $2851.77 \mathrm{~cm}^{-1}, 1427.43$ and $1361.97 \mathrm{~cm}^{-1}$. These bands correspond to aliphatic $\mathrm{C}-\mathrm{H}$ stretching, bending deformations and rocking vibrations of the methylene groups $\left(\mathrm{CH}_{2}\right)$ [32]

\section{- Scanning electron microscopy (SEM)}

In this study, SEM analyses were used to investigate the change in the surface morphology of the flax fibers after cationization treatment. Figure 7 (a) and (b) are SEM photos of the un-treated fabrics and (c) and (d) are that of the cationized ones. As it can be seen from the photos, although the surfaces of the cationized fibers are a little bit rougher compared to the un-treated samples, no significant difference exist between them. These results are compatible with observations obtained by Wang et al. [8]. According to these results it can be said that the physical structure of the flax fiber is almost not influenced by cationization treatment and this process can be applied to linen fabrics prior to dyeing.

\section{- Whiteness index}

Table 5 shows the change in whiteness degree of linen fabrics after cationization treatment. From table 5 it can be seen that the whiteness degree of the cationized linen fabric is lower than the un-treated one. This means yellowing occurs due to the cationization treatment. It is a well-known phenomenon that the disadvantage of cationic agents (especially the quaternary ammonium compounds) is the tendency of treated textiles to yellow. The mechanism of yellowing is thought to be associated with the quaternary

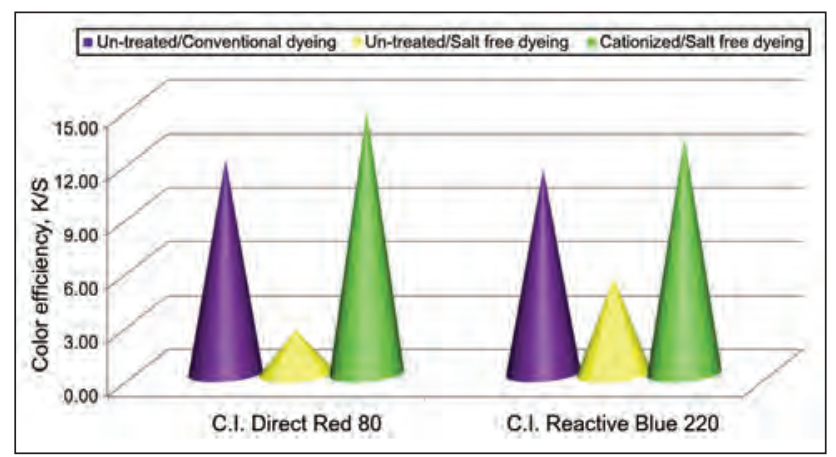

Fig. 8. Color efficiency (K/S) values of linen fabrics dyed with direct and reactive dyes

ammonium groups of cationization agent. Yellowing of fabric is important from the view of dyeing, because it causes changes in nuance of dyed fabrics.

Results related to the salt free dyeability of linen fabrics

After determining the optimum conditions of cationization process, linen fabrics were treated at these conditions and then dyed with a direct and a reactive dye without salt usage. Subsequently colors of these samples were compared with conventionally dyed samples. Color efficiency values of dyed samples are given in figure 8.

As can be seen from figure 8, color efficiency values extremely decrease, if salt is not used in dyeing processes. Another striking point is that the color efficiencies were much higher in case of cationized and salt free dyed samples compared to the conventionally dyed un-treated linen fabrics. As indicated previously, when cellulosic fibers come in contact with water, they produce slightly negative charge. For this reason there is repulsion between anionic fiber and anionic dye molecules. In order to overcome this ionic repulsion, normally electrolytes are added into dye-bath. If salt is not used during dyeing, exhaustion of the dye-bath will be limited. This is why color efficiency values decrease in the absence of salt. On the other hand, when linen fabric is treated with polyaminochlorohydrin quaternary ammonium compound, it gains cationic character and hence it shows high affinity to anionic dyes. As a result, high color efficiency values could be obtained even in the absence of salt.

CIE L*a*b* values of dyed samples were also measured and results are given in table 6.

If $L^{*}$ values given in table 6 are examined, it can be said that $L^{*}$ values of cationized samples are lower than the un-treated ones. $L^{*}$ value is the value of lightness-darkness and the decrease of $L^{*}$ value shows that the color gets darker. From this point of view, the results obtained are parallel with K/S values.

When $a^{*}$ and $b^{*}$ values of un-treated and cationized linen fabrics are compared, it is understood that the difference in $a^{*}$ values are very small, while it is evident in case of $b^{*}$ values. It is seen from table 6 that 


\begin{tabular}{|c|c|c|c|c|c|c|}
\hline \multicolumn{1}{|c|}{ Table 6} \\
\hline Dye & Fabric & L* & $\mathbf{a}^{*}$ & $\mathbf{b}^{*}$ & C* $^{*}$ & $\mathbf{h}$ \\
\hline \multirow{2}{*}{ C.I. Direct Red 80 } & Un-treated & 40,98 & 53,00 & 18,86 & 56,25 & 19,59 \\
\cline { 2 - 8 } & Cationized & 40,86 & 53,61 & 22,48 & 58,13 & 22,75 \\
\hline \multirow{2}{*}{ C.I. Reactive Blue 220 } & Un-treated & 37,95 & $-6,05$ & $-32,54$ & 33,09 & 259,46 \\
\cline { 2 - 8 } & Cationized & 34,15 & $-6,69$ & $-27,76$ & 28,55 & 256,46 \\
\hline
\end{tabular}

Table 7

\begin{tabular}{|c|c|c|c|c|c|c|c|c|c|c|c|}
\hline \multirow{2}{*}{$\begin{array}{l}\text { Dye } \\
\text { class }\end{array}$} & \multirow{2}{*}{ Cationization } & \multirow{2}{*}{ Salt } & \multicolumn{6}{|c|}{ Washing fastness } & \multicolumn{2}{|c|}{ Rubbing fastness } & \multirow{2}{*}{$\begin{array}{c}\text { Light } \\
\text { fastness }\end{array}$} \\
\hline & & & WO & PAC & PES & PA & $\mathrm{CO}$ & $\mathrm{CV}$ & Dry & Wet & \\
\hline \multirow{2}{*}{ Direct } & - & + & 5 & 5 & 5 & 5 & 3 & 5 & $4-5$ & 3 & 7 \\
\hline & + & - & 5 & 5 & 5 & 5 & $2-3$ & 5 & 3 & $1-2$ & $3-4$ \\
\hline \multirow{2}{*}{ Reactive } & - & + & 5 & 5 & 5 & 5 & 5 & 5 & 5 & $3-4$ & 7 \\
\hline & + & - & 5 & 5 & 5 & 5 & 5 & 5 & $3-4$ & 2 & $6-7$ \\
\hline
\end{tabular}

$b^{*}$ values of cationized linen fabrics are higher, which means color nuances become yellowish (in other words less bluish). As it is known, the color nuance of the dyed sample is affected by the material's color prior to dyeing. The reason of change in color nuances could be understood better when whiteness degrees of un-dyed fabrics are investigated. As can be seen in table 5 , whiteness degree of cationized linen fabric is lower than the un-treated one, which means its color is more yellowish. So, this is why higher $b^{*}$ values are obtained in case of cationized fabrics. These results reveal that in dyeing of cationized linen fabrics not only the color depth, but also the color nuance will be different from un-treated sample.

In a dyeing process another important parameter is fastness. For this reason, washing, rubbing and light fastness tests of dyed samples were carried out. Results are given in table 7 .

In table 7, it is seen that washing fastness values of un-treated and cationized linen fabrics are nearly same, while rubbing and light fastness values of cationized linen fabrics are lower compared to untreated samples. The small increase in staining on cotton in case of direct dyeing could be attributable to cationized fabric to be dyed in darker shade compared to un-treated sample.

When table 7 is investigated, it is understood that dry and wet rubbing fastness values of cationized linen fabrics are significantly lower than un-treated samples. As commonly known, cationization process increases the surface affinity of cellulose fibers to anionic dyes and this causes decrease in dye penetration. This is the consequence of reactive dyecationic agent complex formation. Due to steric hindrance, it can block dye diffusion into the fiber and prevent access of dye molecules to functional hydroxyl groups of cotton fiber [33]. As a result, lower rubbing fastness values are obtained.
In table 7, it is seen that light fastness values of untreated samples are fairly high. Light fastness mainly depends on a dye chromophore and dyeing depth. For this reason high light fastness values of dyed samples could be attributed to the chemical structures of dyes used in experiments. Another point that attracts attention is that the light fastness values of cationized fabrics are lower than the un-treated ones. It is a commonly known fact that one of the disadvantages of cationic products is reduced light fastness values. The decomposition of the cationic agents and the formation of free radicals and other chemicals promote the decomposition and fading of the dyes [34].

\section{CONCLUSIONS}

In this study the optimum conditions of cationization process for linen fabrics using the exhaustion method, was found to be $9 \%$ cationization agent, $\mathrm{pH}$ 10 and $75^{\circ} \mathrm{C}$ for 45 minutes. It was determined that the color efficiency was much higher in case of cationized and salt free dyed linen fabrics than the conventionally dyed samples. While the washing fastness properties were comparable, rubbing and light fastness values of cationized samples dyed without salt usage were found to be lower compared to conventionally dyed un-treated fabrics. It can be concluded that with the aid of cationization treatment prior to dyeing, salt usage could be eliminated during dyeing of linen fabrics both with direct and reactive dyes. However, the rubbing and light fastness values were moderate. This may occur depending on dye used and it should be checked before applying the cationization process. Another important point which should be taken into consideration is that the color nuances will be more yellowish in case of cationized linen fabric.

This may require adjustment of dyeing receipt in order to obtain same color nuance with that of conventionally dyed un-treated sample. 


\section{BIBLIOGRAPHY}

[1] Sefain, M.Z., Fadl, M.H., El-Wakil, N.A., Abd El-Salam, M.S. Thermal behaviour of linen and treated linen fibres chemically, In: Polymer Degradation and Stability, 1995, vol. 50, issue 2, pp. 195-198.

[2] Silva, C., Matama, T., Kim, S.-Y., Padrao, J., Prasetyo, E.N., Kudanga, T., Nyanhongo, G.S., Guebitz, G.M., Casal, M., Cavaco-Paulo, A. Antimicrobial and antioxidant linen via laccase-assisted grafting, In: Reactive \& Functional Polymers, 2011, vol. 71, issue 7, pp. 713-720.

[3] Sampaio, S., Shen, J., Bishop, D., Onionen, A.M., Tazanov, T. Progress on enzymatic preparation of flax and flax/wool blends, In: AATCC Review, 2005, vol. 5, issue 5, pp. 23-28.

[4] Dalbaşı, E.S., Çoban, S., Bahtiyari, M.I. An optimization study on crosslinking of linen and cotton fabrics, In: Industria Textila, 2013, vol. 64, issue 5, pp. 235-240.

[5] Fakin, D., Golobm, V., Stana-Kleinschek, K. Influence of enzymatic pretreatment on the colours of bleached and dyed flax fibres, In: Journal of Natural Fibers, 2006, vol. 3, issue 2/3, pp. 69-81.

[6] Atav, R., Namlıgöz, E.S. Keten ve Jüt Liflerinin Boyanması ve Bu Konudaki Yenilikler, In: Tekstil Teknolojileri Elektronik Dergisi, 2009, vol. 3, issue 3, pp. 65-69.

[7] Chattopadhyay, D.P. Cationization of cotton for low-salt or salt-free dyeing, In: Indian Journal of Fiber \& Textile Research, March-June 2001, vol. 26, issue 1-2, pp. 108-115.

[8] Wang, L., Ma, W., Zhang, S., Teng, X., Yang, J. Preparation of cationic cotton with two-bath pad-bake process and its application in salt-free dyeing, In: Carbohydrate Polymers, 2009, vol. 78, issue 3, pp. 602-608.

[9] Singha, K., Maity, S., Singha, M., The salt-free dyeing on cotton: an approach to effluent free mechanism; Can chitosan be a potential option?, In: International Journal of Textile Science, 1(6), 69-77, 2012.

[10] T.-K. Kim, S.-H. Yoon, Y.-A. Son, Effect of reactive anionic agent on dyeing of cellulosic fibers with a berberine colorant, In: Dyes and Pigments, 2004, vol. 60, issue 2, pp. 121-127.

[11] T.S. Wu, K.M. Chen, New cationic agents for improving the dyeability of cellulose fibers, Part 1 - pretreating cotton with polyepichlorohydrin-amine polymers for improving dyeability with direct dyes, In: Journal of the Society of Dyers and Colourists, 1992, vol. 108, issue 9, pp. 388-394.

[12] Özdoğan, E. Selüloz Esası Liflerin Katyonize Edilerek Boyanma ve Baskı Özelliklerinin Geliştirilmesi, Ege Üniversitesi, Fen Bilimleri Enstitüsü, In: Tekstil Mühendisliği Anabilim Dalı, Doktora Tezi, 2003, İzmir, Türkiye.

[13] Evans, G.E., Shore, J., Stead, C.V., Dyeing behaviour of cotton after pretreatment with reactive quaternary compounds, In: Journal Society Dyers and Colorist, October 1984, vol. 100, issue 10, pp. 304-315.

[14] Lewis, D.M., Lei, X.P. Improved cellulose dyeability by chemical modification of the fibre. In: Textile Chemist \& Colorist, 1989, vol. 21, issue 10, pp. 23-29.

[15] Burkinshaw, S.M., Lei, X.P., Lewis, D.M. Modification of cotton to improve its dyeability, Part 1: Pretreating cotton with reactive polyamide-epichlorhydrin resins, In: Journal Society Dyers and Colorist, 1989, vol. 105, issue 11, pp. 391-398.

[16] Burkinshaw, S.M., Lei, X.P., Lewis, D.M., Easton, J.R., Parton, B., Phillips, D.A.S. Modification of cotton to improve its dyeability, Part 2: Pretreating cotton with a thiourea derivative of polyamide-epichlorhydrin resins, In: Journal Society Dyers and Colorist, 1990, vol. 106, issue 10, pp. 307-315.

[17] Lei, X.P., Lewis, D.M. Modification of cotton to improve its dyeability, Part 3: Polyamida-epiclorohydryn resins and their ethylenediamine reaction products, In: Journal Society Dyers and Colorist, 1990, vol. 106, issue 11, pp. 352-356.

[18] Lei, X.P., Lewis, D.M. The dyeing behaviour of cotton modified with chloropropionyl chloride and related compounds, In: Dyes and Pigments, 1991, vol. 16, issue 4, pp. 273-289.

[19] Lewis, D.M., Lei, X.P. New methods for improving the dyeability of cellulose fibres with reactive dyes, In: Journal Society Dyers and Colorist, 1991, vol. 107, issue 3, pp. 102-109.

[20] Peter, J.H., Adham, H.T. Dyeing cationic cotton with fiber reactive dyes: Effect of reactive chemistries, In: AATCC Review, 2002, vol. 2, issue 5, pp. 36-39.

[21] Hebeish, A., Hashem, M., EL-Hosamy, M., Abass, S. Cationization of linen fabric: studying the process parameters, In: RJTA, 2006, vol. 10, issue 1, pp. 73-88.

[22] Hebeish, A., Hashem, M., EL-Hosamy, M., Abass, S. No-salt dyeing behaviour of cationized linen fabrics, In: RJTA 2006, vol. 10, issue 2, pp. 43-57.

[23] Mashaly, H.M., Hauser, P.J. Cold pad batch cationization and dyeing of linen fabric with reactive dyes, In: Research Journal of Textile \& Apparel, August 2012, vol. 16, issue 3, pp. 111-118.

[24] Mashaly, H.M., Hauser, P.J. Cationization assisted dyeing: dyeing of linen fabric with some acid and direct dyes, In: Man-Made Textiles in India, September 2012, vol. 4, issue 9, pp. 312-317.

[25] Haroun, A.A., Mansour, H.F. Effect of cationisation on reactive printing of leather and wool, In: Dyes and Pigments, 2007, vol. 72, issue 1, pp. 80-87.

[26] ISO 105-C10:2006, Textiles - Tests for color fastness, Part C10: Color fastness to washing with soap or soap and soda, International Organization for Standardization, Geneva. 
[27] ISO 105-X12:1993, Textiles - Tests for color fastness, Part X12: Color fastness to rubbing, International Organization for Standardization, Geneva.

[28] ISO 105-B02:1994, Textiles -Tests for color fastness, Part B02: Color fastness to artificial light, International Organization for Standardization, Geneva.

[29] Ahmad, M., Jamil, N.A., Saee, M.A. Nitrogen, lignin, wax and ash contents in flax (linum usitatissimum), In: Pakistan J. Agric. Res., 1982, vol. 3, issue 2, pp. 78-83.

[30] Ren, X., Buschle-Diller, G. Oxidoreductases for modification of linen fibers, In: Colloids and Surfaces A: Physicochem. Eng. Aspects, 2007, vol. 299, issue 1-3, pp. 15-21.

[31] Garside, P., Wyeth, P. Identification of cellulosic fibres by ftir spectroscopy: thread and single fibre analysis by attenuated total reflectance, In: Studies in Conservation, 2003, vol. 48, issue 4, pp. 269-275.

[32] Kamel, M.M., El Zawahry, M.M., Ahmed, N.S.E., Abdelghaffar, F. Ultrasonic dyeing of cationized cotton fabric with natural dye, Part 1: Cationization of cotton using solfix E, In: Ultrasonics Sonochemistry, 2009, vol. 16, issue 2, pp. 243-249.

[33] Ristic, N., Ristic, I. Cationic modification of cotton fabrics and reactive dyeing characteristics, In: Journal of Engineered Fibers and Fabrics, 2012, vol. 7, issue 4, pp. 113-121.

[34] Yang, Y., Carman, E.F. Non-formaldehyde nitrogen-containing fixing agent for direct dyeing, In: American Dyestuff Reporter, October 1996, vol. 85, issue 10, pp. 39-44.

\author{
Author: \\ Assoc. Prof. Dr. Riza ATAV \\ Namık Kemal University \\ Department of Textile Engineering \\ Corlu-Tekirdag, Turkey \\ e-mail: ratav@nku.edu.tr \\ Corresponding author: \\ Assoc. Prof. Dr. Rıza ATAV \\ e-mail: ratav@nku.edu.tr
}




\section{Embroidery - from digital designing to fine art}

DOI: $10.35530 / 1 T .068 .05 .1429$

\section{REZUMAT - ABSTRACT}

\section{Broderia - de la design digital la artă}

Din cele mai vechi timpuri, omul a folosit broderia pentru a adăuga valoare culturală şi economică îmbrăcămintei sau pentru a-și personaliza hainele, iar rezultatul a fost un bogat patrimoniu de artă decorativă. Astăzi, design-ul produselor textile brodate este aliniat la tehnologii avansate, în funcție de ceea ce este la modă sau în trend. Prelucrarea imaginilor digitale este acum o parte a procesului de design textil şi mulți designeri de modă folosesc CAD-ul cu scopul de a creşte precizia, productivitatea şi de a oferi informații organizate, dar și pentru a reduce timpii morți în producție, reducând astfel si costurile articolelor de îmbrăcăminte.

Lucrarea de față prezintă modul cum un design textil poate fi creat prin intermediul sistemului universal CAD ASCON Kompas (s-a proiectat forma simbolului "Floarea Vieții" din geometria sacră) şi Adobe Photoshop (pentru combinația de culori). In continuare, s-au importat formele în Hatch Embroidery Software pentru a crea modele de broderie. Folosind Adobe Illustrator, s-au realizat câteva schițe grafice de articole de îmbrăcăminte, pe care s-au adăugat broderiile proiectate.

Prin softurile folosite s-au experimentat culori, texturi, modele și schite pentru a genera un design jucăuș, distinct și animat, fără a produce fizic articolul de îmbrăcăminte.

Cuvinte-cheie: geometria sacră, Floarea Vieții, design textil, broderii, Adobe Photoshop, ASCON Kompas, Hatch Embroidery Software, Adobe Illustrator

\section{Embroidery - from digital designing to fine art}

From the earliest times, the man has used embroidery to add cultural and economic value or to personalize the clothes and the result was a rich heritage of embellishment. Today the design of embroidered textiles is aligned to the advanced technologies, according to what is fashionable or on-trend. Digital imaging is now a part of the textile design process and many fashion designers use the CAD in order to increase the precision, productivity and to offer organized information, but also to reduce lead times in production, thus reducing cost of garments.

This paper will show how a textile design can be created by the means of the universal CAD system ASCON Kompas (we designed the shape of Sacred Geometry's symbol "Flower of Life") and Adobe Photoshop (for the colour combination). Later on we imported the designs in Hatch Embroidery Software, in order to create the embroidery models. Using Adobe Illustrator, we drawn some graphic sketches of garments and on those we added the embroideries which we already designed.

The software which we used offered us the benefit of experimenting with a number of colours, textures, patterns and sketch backgrounds for producing a playful, distinct and animated design, without physically making a garment.

Keywords: sacred geometry, Flower of Life, textile designs, embroideries, Adobe Photoshop, ASCON Kompas, Hatch Embroidery Software, Adobe Illustrator

\section{INTRODUCTION}

The origin of embroidery is lost in time. In the past women required years of practice and experience to master this craft, therefore embroidered garments were used only on holidays or special occasions, as these had to be prepared in advance.

Because of its decorative potential, the embroidery, became an integral part of couture industry [1-2]. In today's world fashion, the designers demonstrate their creativity and originality by combining weaving techniques, yarns, patterns, and embroideries in one garment. For Spring Summer 2017, the main focus of designer collections is embroideries, flowers being the guiding theme in fashion. This season's embroidery theme is all about provoking our sense of perception and combining the femininity of embroidery with unusual shapes, in order to create a playful, distinct and animated effect.

Taking into account the fashion trends, in the present paper the authors intended to create different textile designs by the means of the universal CAD system ASCON Kompas for design of shape and Adobe Photoshop for color combinations, inspired by the Sacred Geometry's symbol - the Flower of Life [3-4]. The designs were later on imported in Hatch Embroidery Software thus to create the embroidery designs. In order to see how these embroideries look on a garment, using Adobe Illustrator, graphic sketches of garments were drawn on which some of the created embroideries were added. 


\section{TEXTILE DESIGN ON THE BASE OF FLOWER OF LIFE}

The universe we live in is made of shapes and all the shapes are arranged according to a set of invisible mathematic rules that govern the structures and proportions. The nature of these patterns, forms and relationships and their connections may be gained into the mysteries - the laws of the Universe. The great sum of knowledge that governs the universe is named sacred geometry. This means the nature communicates with us through shapes.

Sacred geometry was often employed in the design, architecture, fabrication and construction of sacred structures and spaces, in religious art, iconography; also, its harmonics and proportion were found in music, light and cosmology as well as in jewelry and clothing.

One of the symbols of sacred geometry is the Flower of Life (figure 1) [5]. Composed of seven or more evenly-spaced, overlapping circles, this figure forms a flower-like pattern. Its most common form is hexagonal (the center of each circle being on the circumference of six surrounding circles of the same diameter), made up of 19 complete circles and 36 partial circular arcs, enclosed by a large circle.

Scientists, philosophers, psychologists, architects and artist around the world contemplated the perfect form, proportion and harmony of the Flower of Life. Leonardo da Vinci [6] studied its form and mathematical properties and he was fascinated by how the Flower of Life connected to physical reality as well as consciousness. He drew the Flower of Life itself, as well as various components such as the Seed of Life. He drew geometric figures representing shapes such as the platonic solids, a sphere, a torus, etc., and also used the golden ratio of phi in his artwork; all of which may be derived from the Flower of Life.

Today the fashion designers continue to deconstruct and reinvent certain textile motifs and patterns, hence the Flower of Life is enjoying a new life as emblem of cutting edge contemporary fashion.

In this context the present paper illustrates the way of creating different embroidery models, by using CAD software, which were then applied on garments. A first step in making up the product was to create 4 textile models, based on the symbol Flower of Life, using the instruments of CAD system Ascon Kompas (figure 2).

The patterns use the Flower of Life which was created with 19 circles. The first ornament was created in a gamma of four colors, which follows the radial symmetry and rhythm of the flower. The second pattern uses four colors arranged on the base of bilateral symmetry in vertical direction. The third and fourth ornaments use five colors models. In both patterns hexagon spirals were designed with the help of three colors. Hexagon spirals were arranged with radial symmetry and rhythm. The colors were chosen on

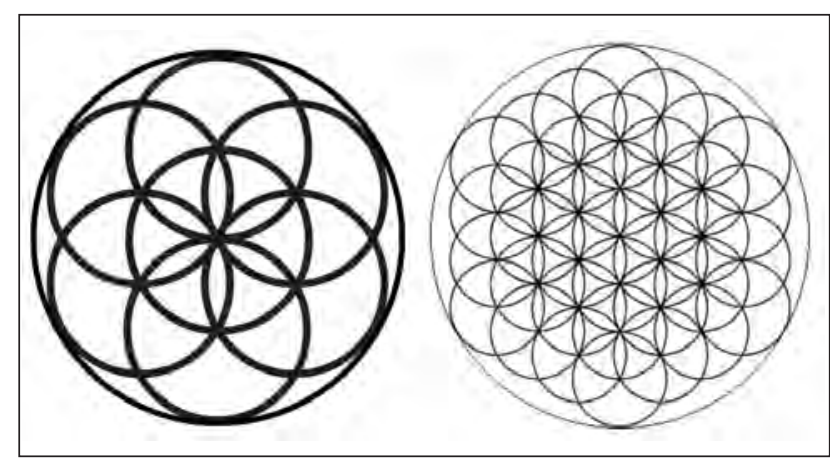

Fig. 1. Flower of Life
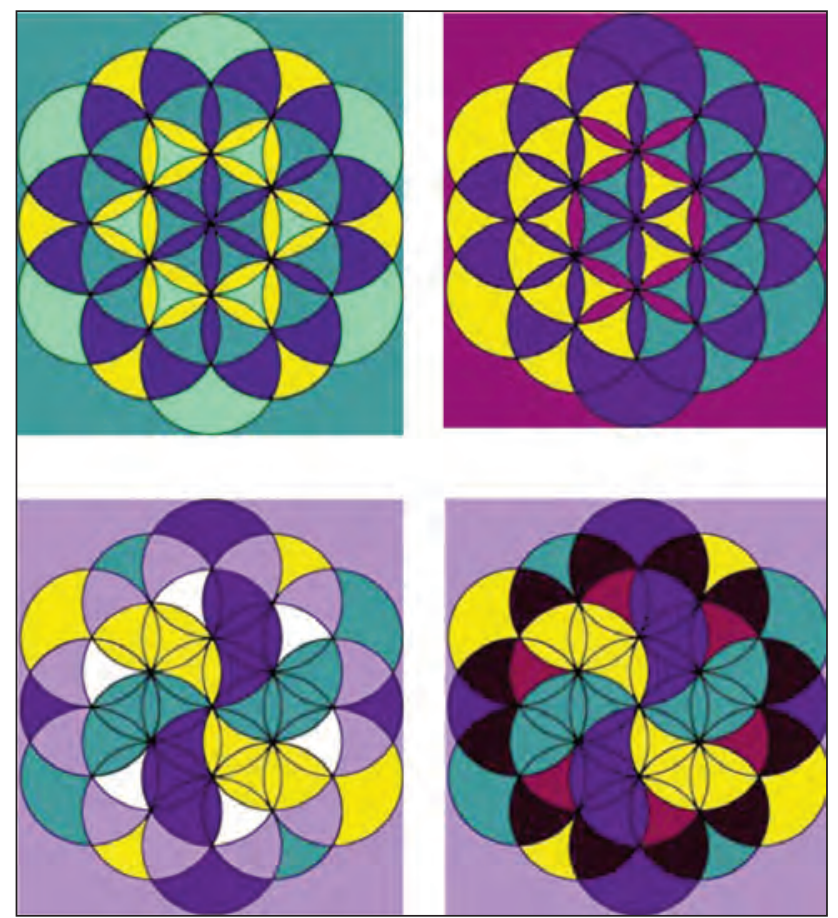

Fig. 2. Textile designs on the base of Flower of Life

the base of the color symbolism and meaning ,the national tradition and of course the latest fashion trends [4-9].

\section{CREATE EMBROIDERY DESIGNS}

The textiles designs were inserted into the Hatch Embroidery Software and displayed on screen. Hatch Embroidery Software is the latest release from Australian company Wilcom, a global leader in embroidery software solutions [10]. The software transforms creative ideas into high quality embroidery and provides accurate, attractive outlines for designs in order to: take a ready-made design and sew it out; make global changes to a design, combine lettering with a design; create a monogram design, adapt an existing design; create embroidery from artwork using automated techniques; create embroidery manually; use special embroidery features.

Using on screen' digitizing method, the authors used the pointer of the mouse to define the design in 


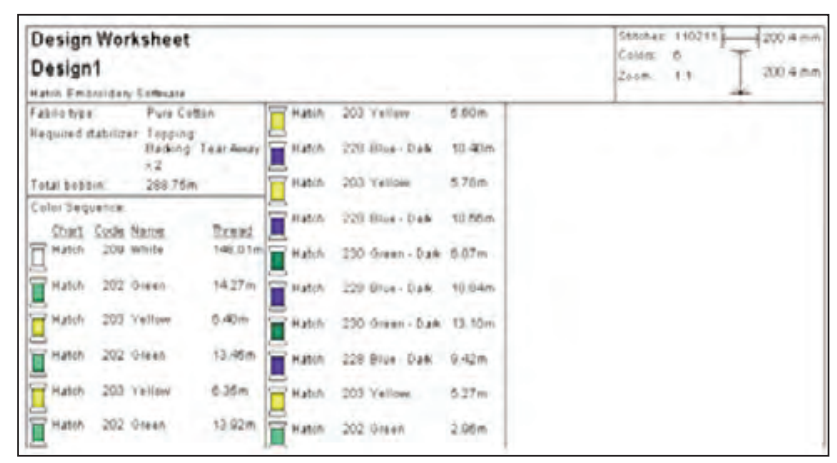

Fig. 3. Technical requirements

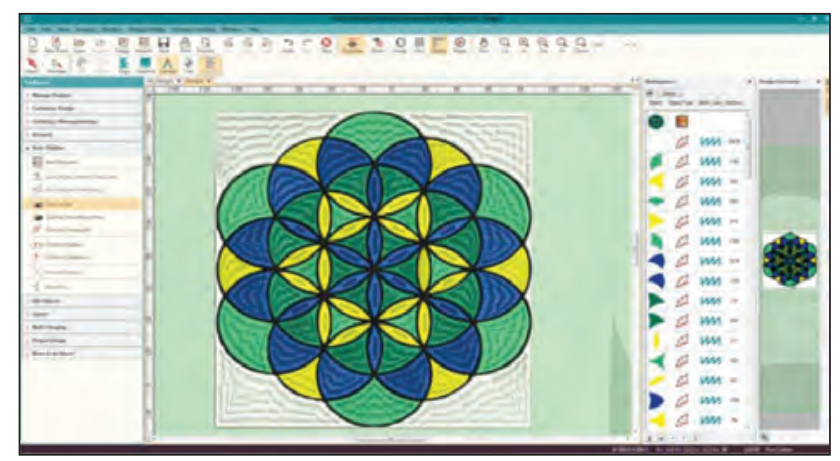

Fig. 4. Stitch types and colors
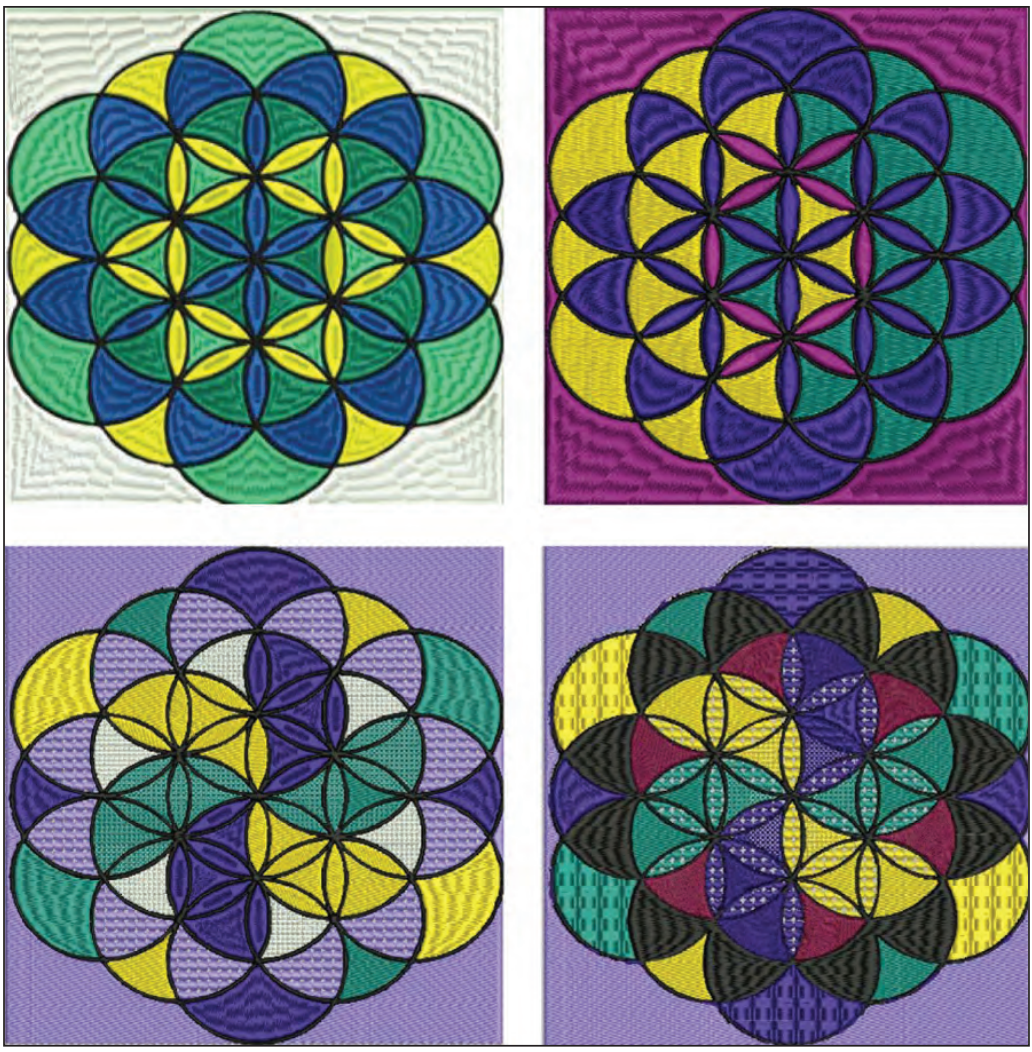

Fig. 5. Embroidery's design using Hatch Embroidery Software

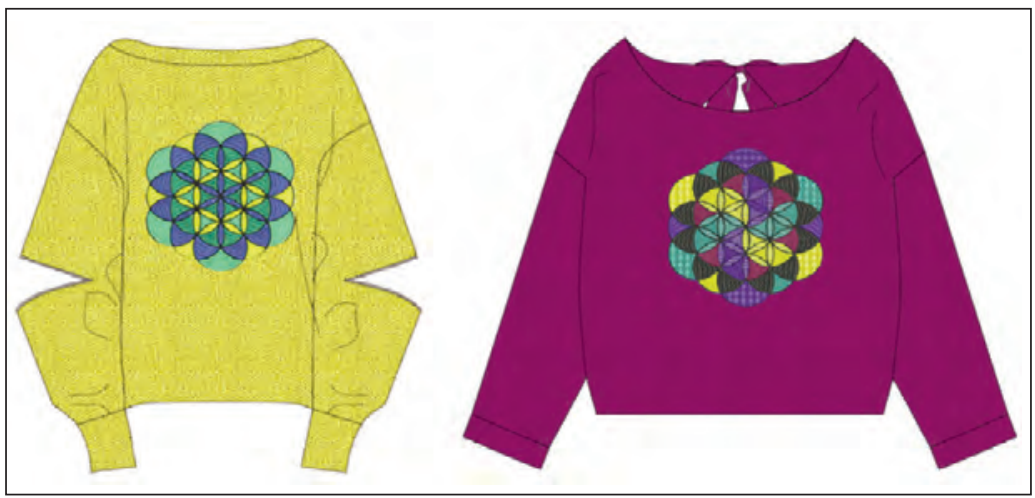

Fig. 6. Embroideries in the completed garment

We have established technical requirements: the type of fabric to be embroidered on, the scale of the design, the number of stitches, and the number of colors (figure 3 and 4).

Hatch Embroidery Software offers a variety of thread colors to achieve the most accurate color representation for embroidery. When we uploaded our artwork and selected the embroidery, the programme automatically detected and displayed colors in our artwork that matched our available thread colors. We adjusted design thread colors to find a combination that suited the background colors of our textile designs. We chose from a palette of stitch types to create the embroidery design (figure 5). The stitch types were pre-programmed and used to create stitch blocks or objects that were filled with a certain stitch type (in our embroidery we used Tatami, Satin, Motif, Cross stich, Embossed).

When the embroidery design was completed the design was saved as .emb file.

In order to visualize how the embroideries will look in the completed garment we used Adobe Illustrator (figure 6).

\section{CONCLUSIONS}

CAD has become an important part of textile and apparel, being widely used in the design of yarns, fabrics and garments.

This paper emphasizes the role of CAD technology in developing virtual textile design and embroidery samples on the computer screen and simulating the appearance of embroidery without wasting materials and manufacturing

stitches. The digitizer will create blocks using different stitch types, different angles of stitching and changes of color. process. The focus of the paper then shifts specifically to the role of visualization technology in enabling an integrated digital process. 


\title{
BIBLIOGRAPHY
}

[1] Șuteu, M., Stan, O., Doble, L. Improving the aesthetic look of garments, using computerized graphics programs, In: Annals of the University of Oradea, Fascicle of Textiles-Leatherwork, Oradea, vol. XVII, nr. 2, 2016, pp. $133-137$.

[2] Florea, M., Neagu I. The alternative CoreIDRAWings an ideal solution for designers, in embroidery, In: Annals of the University of Oradea, Fascicle of Textiles-Leatherwork, Oradea, vol. XIV, nr. 1, 2016, pp. 127-131.

[3] Kazlacheva, Z. Fibonacci tilings in Fashion design, In: Annals of the University of Oradea, Fascicle of Textiles-Leatherwork, Oradea, vol. XVII, nr. 1, 2016, pp. 77-82.

[4] Ilieva, J. Textile design on the base of the Golden geometry and Bulgarian national tradition, In: Annals of the University of Oradea, Fascicle of Textiles-Leatherwork, Oradea, vol. XVII, nr. 2, 2016, pp. 69-74.

[5] Drunvalo, M. Ancient secret of the Flower of Life (vol.1). [Online] pp. 31-44. Available: https://www.scribd.com/ doc/46987809/Drunvalo-Melchizedek-Ancient-Secret-of-the-Flower-of-Life-Vol-1

[6] Drunvalo, M., Ancient Secret of The Flower of Life (vol. 2). [Online] pp. 242. Available: https://www.scribd.com/ doc/210914088/Drunvalo-Melchizedek-Ancient-Secret-of-the-Flower-of-Life-Vol2-pdf.

[7] Kazlacheva, Z. Visual organization of colors and lines in clothing, In: Tekstil i Obleklo, Sofia, vol. 58, nr. 8, 2010, pp. 242-248.

[8] Kazlacheva, Z., llieva, J., Zhekova, M., Dineva, P. Fashion design on the base of connections between colors and lines, In: ARTTE Applied Researches in Technics, Technologies and Education, Yambol, vol. 2, nr. 1, 2014, pp. 54-64.

[9] Zlatev, Z., Boneva, P., Stoykova, V., EINashar, E. Transfer of embroidery elements from Bulgarian national folk costume to the contemporary fashion, In: ARTTE Applied Researches in Technics, Technologies and Education, Yambol, vol. 4, nr. 2, 2016, pp. 105-117.

[10] *** Hatch. Bring embroidery to life. User guide, In: Wilcom Pty Ltd., Sydney, Australia. [Online] Available: http://www.wilcom.com

\section{Authors: \\ LILIANA INDRIE ${ }^{1}$ \\ ZLATINA KAZLACHEVA ${ }^{2}$ \\ JULIETA ILIEVA ${ }^{2}$ \\ SABINA GHERGHEL ${ }^{1}$}

${ }^{1}$ University of Oradea, Faculty of Energy Engineering and Industrial Management, Department of Textiles, Leather and Industrial Management

B.St. Delavrancea Str. no. 4, 410058, Oradea, Romania, e-mail: lindrie@uoradea.ro, sgherghel@uoradea.ro

2 Trakia University of Stara Zagora, Faculty of Technics and Technologies of Yambol Graf Ignatiev 38, 8600, Yambol, Bulgaria e-mail: zlatinka.kazlacheva@trakia-uni.bg, zhulieta.ilieva@trakia-uni.bg

\author{
Corresponding authors: \\ LILIANA INDRIE \\ e-mail: lindrie@uoradea \\ ZLATINA KAZLACHEVA \\ e-mail: zlatinka.kazlacheva@trakia-uni.bg
}




\section{Improving fit of work uniforms used in laboratories and workshops}

Îmbunătățirea ajustării pe corp a uniformelor din laboratoare și ateliere de lucru

Confortul îmbrăcămintei poate fi descris ca fiind un sentiment de satisfacție fiziologică, psihologică și fizică și de echilibru în ceea ce privește îmbrăcămintea și condițiile actuale de mediu.

Scopul acestui studiu este de a evalua confortul de mișcare a corpului în uniformele de lucru purtate de personalul care lucrează în laboratoare și ateliere prin intermediul studiilor de uzură, pentru a determina potențialii factori care afectează negativ confortul de mișcare a corpului, pentru a efectua modificări de model în scopul asigurării satisfacției utilizatorilor și propunerii unui exemplu de tipar de uniformă de lucru.

La sfârșitul studiului, s-au făcut unele modificări privind tiparul de bază al uniformei de lucru pe baza datelor obținute din parametrii de cercetare.

Cuvinte-cheie: ajustare pe corp, uniformă de lucru, modificări ale tiparului, confortul mișcării corpului

\section{Improving fit of work uniforms used in laboratories and workshops}

Clothing comfort can be described as an individual's feeling physiologically, psychologically and physically satisfied and balanced in that clothing and under current environmental conditions.

The purpose of this study is to evaluate the body movement comfort of work uniforms used by people working in laboratories and workshops through wear trials, to determine the factors, if any, that negatively affect the body movement comfort, to make pattern modifications to ensure user satisfaction, and to propose an example work uniform pattern model.

At the end of the study, some modifications were made on the basic work uniform pattern based on the data obtained from research parameters.

Keywords: fitting, work uniform, pattern modifications, body movement comfort

\section{INTRODUCTION}

Clothing comfort can be described as an individual's feeling physiologically, psychologically and physically balanced and satisfied in that clothing and under the current environmental conditions [1, 2]. In other words, all functions of a clothing such as providing movement comfort physiologically and psychologically to the wearer, acting as a thermo-regulation system against ambient temperature changes, and making a person psychologically happy with their appearance as well as their aesthetic and attitude features can be defined as clothing comfort. Improvement of clothing comfort raises people's living standards [3].

Clothing comfort consists of the sub-components of thermal comfort, sensory (tactile) comfort, body movement comfort and psychological (aesthetic) comfort [4]. Body movement comfort which is the topic of this study has an important place among the components of comfort.

In terms of clothing comfort, it is vital that the clothing does not restrict body movements and adapts itself to these movements $[5,6]$. That the clothing does not restrict body movements and adapts itself to these movements can only be possible if the clothing pattern is prepared suitably for the body.

Several studies conducted on this topic were summarized as follows.
In their studies, Choi and Ashdown (2002) developed clothes for the farmers that picked pears in the city of Naju, Korea. In the first phase of the study, field observations, interviews and surveys were conducted regarding both female and male farmers. The survey was administered to 113 people; 42 females, and 71 males. In accordance with the survey results, 4 prototype samples consisting of jacket and trousers for females were developed. The aim was to improve the working performance and clothing comfort of the workers while developing the samples. At the end of the study, the samples were subjected to wear trials, and were evaluated by the female workers and experts in terms of fit, function and aesthetics, and the optimum clothing was tried to be discovered [7]. Schofield et al. (2006) examined the relationship between the body shapes of people over 55 years old and the sizes and patterns of the trousers they wore. They tested the trousers with two different fit types on 176 subjects and compared the results [8].

Ho et al. (2008) tested eight sports outfits on 14 pregnant women around $32.3 \pm 4.2$ years old. Within the study, the thermo-physiologic, tactile and body movement comforts of the clothes were examined. At the end of the wear trials, it was stated that the clothing types and models affected the body movement comfort [9]. 
Çoruh (2009) examined the ergonomics of jeans. Within the study, a survey was conducted in order to examine the ergonomics of jeans, to determine the problems that the individuals wearing jeans encountered, and to propose design for the ergonomics of jeans patterns based on these problems. The problems identified were categorized into 4 factors including discomfort of tightness, discomfort of climbing up stairs, discomfort of strain and discomfort of waistbaring. As a result, some recommendations were made on jeans patterns for the purpose of making ergonomic jeans [10].

In their studies, Çivitçi and Çakmak (2009) examined the effect of fabric structures with surface extension ability and different fiber construction on model and pattern designs of female trousers in ready-made clothing sector. Accordingly, they conducted wear trials on 24 people with six different fabric types, and necessary modifications were made on the trousers patterns thanks to the findings obtained at the end of the evaluation [11].

In their studies, Çoruh et al. (2011) developed a scale in order to evaluate the physical comfort of jeans. During the scale-development process, young people were interviewed regarding the problems that they encountered related to jeans in their daily life, the literature on clothing comfort was examined, and the experts working in ready-made clothing sector were interviewed. In the light of the information obtained, a scale consisting of 19 items was developed in order to assess the physical comfort of jeans, and validity and reliability analyses were performed [12].

Komarkova and Glombikova (2013) studied the effect of the anatomical changes during pregnancy on the pattern design of maternity wear. Accordingly, they measured the body sizes of the pregnant women at the beginning of their pregnancy and in the $36^{\text {th }}$ and $41^{\text {st }}$ weeks, and then, they worked on to develop one blouse and one trousers pattern. At the end of the study, they developed patterns suitable for the body types of pregnant women [13].

Utkun (2014) analyzed the body movement comfort performances of three different classical male shirts intended for bellied males through wear trials that were conducted on a group of 10 subjects. The fit of the shirts to the body, as well as their comfort during movement were separately analyzed through these wear trials. At the end of the study, the belly size concept was recommended to be used in the production of classical shirts for males [14].

The purpose of this study is to evaluate fit of work uniforms worn by people working in laboratories and workshops, to determine the factors, if any, that negatively affect the body movement comfort, to make pattern modifications to ensure user satisfaction, and to propose an example work uniform pattern model. For the study, necessary ethical permissions were obtained from the Pamukkale University Ethics Committee with the document no: 20678 on 29.03.2016.

\section{EXPERIMENTAL PART}

\section{Materials}

The materials of the study consisted of 21 females (38-size) who voluntarily attended the wear trials and wore work uniforms in workshops, and one uniform produced out of the 38-size standard female patterns according to the Muller system.

The age of the volunteers who participated in the wear trials ranged from 18 to 23 . The average bust measurement of these subjects was $90 \pm 2 \mathrm{~cm}$, their average waist measurement was $66 \pm 2 \mathrm{~cm}$, average hip measurement was $94 \pm 2 \mathrm{~cm}$, average sleeve length was $6 \pm 2 \mathrm{~cm}$, and average height was between $155 \mathrm{~cm}$ and $170 \mathrm{~cm}$.

Within the study, one standard 38-size female work uniform was produced. The work uniform model is described as men's collar uniform with five buttons in the front, one top pocket and two bottom pockets in the front, removable sleeves, and center back seam (figure 1). The type of the woven fabric used in the production of the work uniforms was alpaca and consisted of $75 \%$ cotton and $25 \%$ viscose, and its fabric weight was $180 \mathrm{~g} / \mathrm{m}^{2}$.

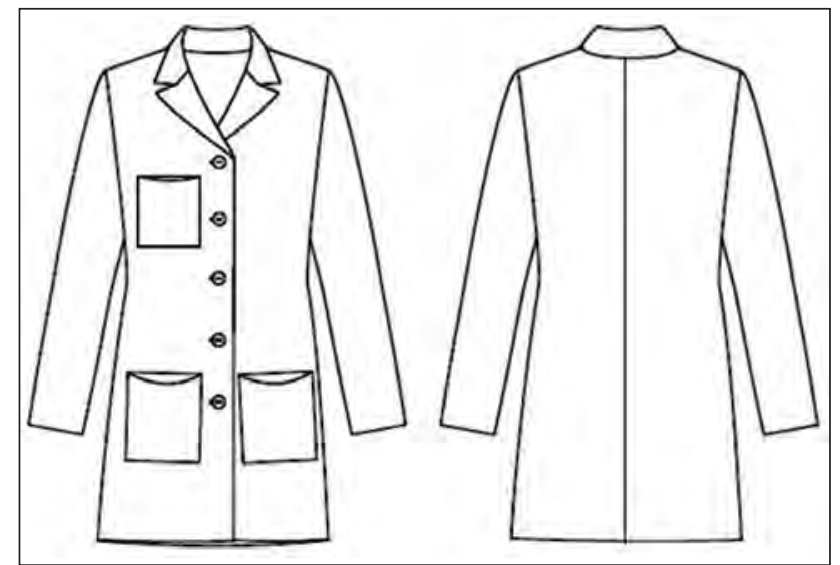

Fig. 1. Classical female work uniform (front and back view)

While preparing the work uniform patterns, primarily the basic work uniform patterns were prepared, and then, the front part and the back part, as well as the sleeve patterns were created. The standard size table used when preparing the basic work uniform patterns was illustrated in table 1. The basic patterns of the front and back part, collar and back yoke of the uniform were shown in figure 2 , and the expansion of the patterns was shown in figure 3 .

\section{Method}

At the initial phase of the study, one work uniform was produced. This work uniform was subjected to wear trials on 21 females one by one, and the fit of the uniform to the body and their comfort during movement were separately analyzed, and in addition to these, the fit of the length and width of the uniform to the body were observed when the uniform was worn. 


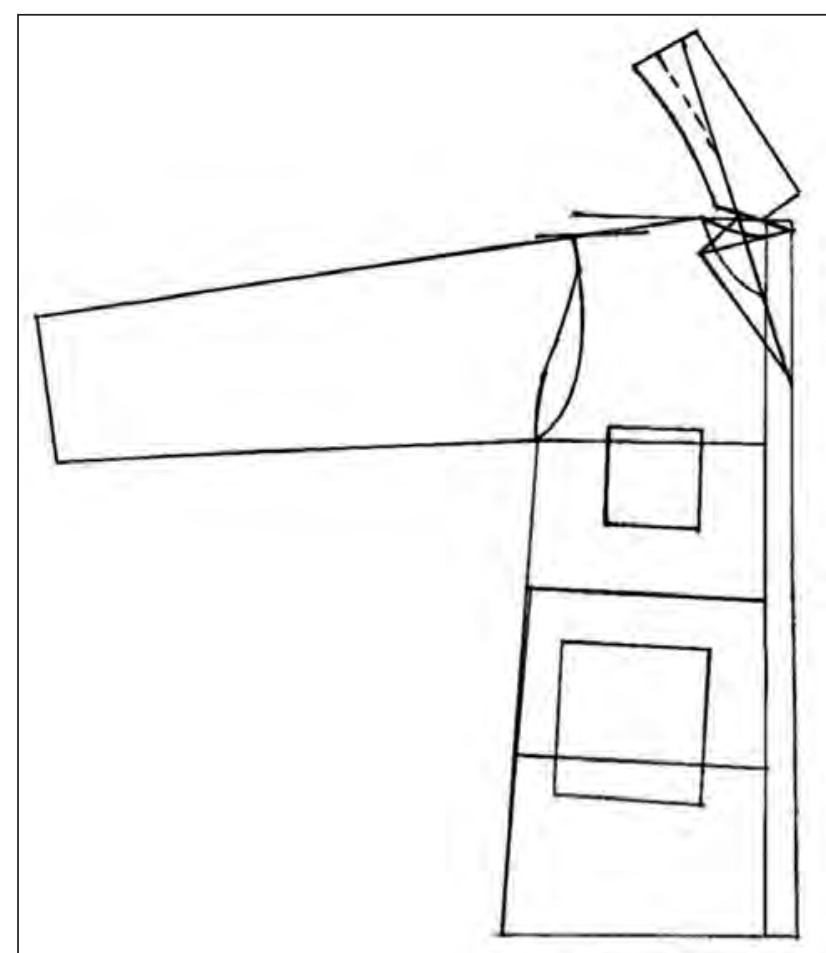

Fig. 2. The basic patterns of the work uniform for front and back partsiew)
Table 1

\begin{tabular}{|l|c|}
\hline \multicolumn{2}{|c|}{ SIZE TABLE } \\
\hline Measurements $(\mathbf{c m})$ & Size $\mathbf{3 8}$ \\
\hline Length (from shoulder) & 82 \\
\hline Chest girth & 90 \\
\hline Hip girth & 94 \\
\hline Waist girth & 66 \\
\hline Shoulder width & 15 \\
\hline Collar opening & 15 \\
\hline Front collar drop & 9 \\
\hline Back collar drop & 2 \\
\hline Arm length & 60 \\
\hline Wrist width & 16 \\
\hline Armhole height & 23 \\
\hline Shoulder drop & 2.5 \\
\hline
\end{tabular}

The parameters researched during the wear trials were given in table 2, 3 and 4. The parameters analyzed during the wear trials were reviewed by a specialist along with the wearer.

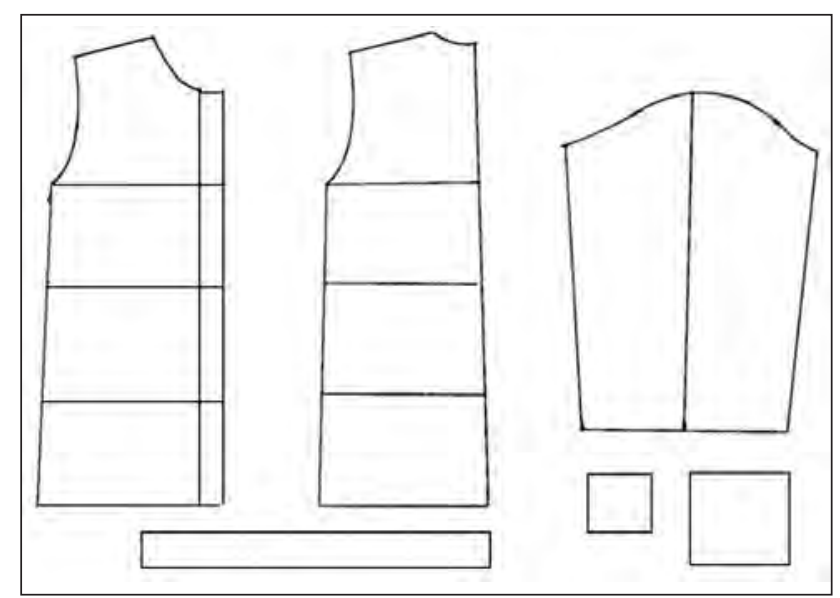

Fig. 3. The expansion of the front and back parts and sleeve pattern

It was determined that although the bust size of these people fitted to 38-size, there were problems with the length and width, and the work uniform did not provide body movement comfort. From this point forth, within the scope of this study, comparative analyses were done based on the frequency analysis, one of the statistical techniques, and modifications were made on the basic work uniform patterns.

\section{RESULTS AND DISCUSSION}

The frequency analyses of the parameters researched during the study are presented in table 5, 6 and 7.

A total of $23.8 \%$ of the survey participants think that their work uniform was suitable for their body movements, $61.9 \%$ of them think that it was not suitable, and $14.3 \%$ of them were neutral about this issue. In addition, $14.3 \%$ of the participants think that removable sleeves were suitable for their body movements, $71.5 \%$ of them think that removable sleeves were not suitable, and $14.3 \%$ of them adopted a neutral position.

According to the research results, the majority of the individuals wearing a work uniform believe that their work uniforms were not suitable for their body movements. Based on these results, some modifications were made on the basic work uniform pattern. These pattern modifications are displayed with red lines in figure 4.

Based on the data obtained from the research results, the model length and belt length of the work uniform were shortened, and the top pocket and back pocket height were increased, but the button

THE PARAMETERS RESEARCHED DURING THE WEAR TRIALS REGARDING CLOTHING COMFORT

\begin{tabular}{|c|l|l|l|c|c|}
\hline No. & Clothing comfort questions & Strongly agree & Agree & Neutral & Disagree \\
\hline 1 & $\begin{array}{l}\text { I think my work uniform adapts itself to my } \\
\text { body movements. }\end{array}$ & & & & \\
\hline 2 & $\begin{array}{l}\text { I think my work uniform with removable } \\
\text { sleeves adapts itself to my body movements. }\end{array}$ & & & & \\
\hline
\end{tabular}


THE PARAMETERS RESEARCHED DURING THE WEAR TRIALS REGARDING LENGTH MEASUREMENTS

\begin{tabular}{|c|l|c|c|}
\hline No & Length Measurements Questions & Short & Normal \\
\hline 3 & I think the model length of my work uniform is sufficient. & & \\
\hline 4 & I think the armhole height of my work uniform is sufficient. & & \\
\hline 5 & I think the space between the buttonholes and buttons of my work uniform is sufficient. & & \\
\hline 6 & I think the stitch length (1cm 3stitch) of my work uniform is sufficient. & & \\
\hline 7 & I think the belt length of my work uniform is sufficient. & & \\
\hline 8 & I think the arm length of my work uniform is sufficient. & & \\
\hline 9 & I think the top pocket height of my work uniform is sufficient. & & \\
\hline 10 & I think the bottom pocket height of my work uniform is sufficient. & & \\
\hline
\end{tabular}

THE PARAMETERS RESEARCHED DURING THE WEAR TRIALS REGARDING WIDTH MEASUREMENTS

\begin{tabular}{|c|l|c|c|}
\hline No & Width Measurements Questions & Tight & Normal \\
\hline 11 & I think the hem width of my work uniform is suitable for my movements. & & \\
\hline 12 & I think the wrist width of my work uniform is suitable. & & \\
\hline 13 & I think the shoulder width of my work uniform is suitable. & & \\
\hline 14 & I think the collar opening of my work uniform is sufficient. & & \\
\hline 15 & I think the armhole width of my work uniform is sufficient. & & \\
\hline 16 & I think the collar width of my work uniform is sufficient. & & \\
\hline 17 & I think the top pocket width of my work uniform is sufficient. & & \\
\hline 18 & I think the bottom pocket width of my work uniform is sufficient. & & \\
\hline
\end{tabular}

\begin{tabular}{|c|c|c|c|c|}
\hline \multicolumn{5}{|c|}{ RESULTS REGARDING CLOTHING COMFORT } \\
\hline No. & $\begin{array}{c}\text { Strongly } \\
\text { agree }\end{array}$ & Agree & Neutral & Disagree \\
\hline 1 & 4.8 & 19.0 & 14.3 & 28.6 \\
\hline 2 & 4.8 & 9.5 & 14.3 & 42.9 \\
\hline
\end{tabular}

Table 6

\begin{tabular}{|c|c|c|c|}
\hline \multicolumn{4}{|c|}{ RESULTS REGARDING LENGTH MEASUREMENTS } \\
\hline No. & $\begin{array}{c}\text { Short } \\
(\%)\end{array}$ & $\begin{array}{c}\text { Normal } \\
(\%)\end{array}$ & $\begin{array}{c}\text { Long } \\
(\%)\end{array}$ \\
\hline 3 & 23.8 & 14.3 & 61.9 \\
\hline 4 & 14.3 & 23.8 & 61.9 \\
\hline 5 & 19.0 & 57.1 & 23.8 \\
\hline 6 & 9.5 & 38.1 & 52.4 \\
\hline 7 & 14.3 & 23.8 & 61.9 \\
\hline 8 & 52.4 & 14.3 & 33.3 \\
\hline 9 & 52.4 & 4.8 & 42.9 \\
\hline
\end{tabular}

hole-button spacing was not changed. The hem and top pocket of the work uniform were enlarged, and the shoulder width was narrowed, but the collar opening, collar width and the bottom pocket width were not changed.

\begin{tabular}{|c|c|c|c|}
\hline \multicolumn{5}{|c|}{ RRESULTS REGARDING WIDTH MEASUREMENTS } \\
\hline No. & $\begin{array}{c}\text { Tight } \\
\mathbf{( \% )}\end{array}$ & $\begin{array}{c}\text { Normal } \\
\mathbf{( \% )}\end{array}$ & $\begin{array}{c}\text { Large } \\
\mathbf{( \% )}\end{array}$ \\
\hline 11 & 52.4 & 23.8 & 23.8 \\
\hline 12 & 9.5 & 28.6 & 61.9 \\
\hline 13 & 9.5 & 23.8 & 66.7 \\
\hline 14 & 9.5 & 66.7 & 23.8 \\
\hline 15 & 61.9 & 19.0 & 19.0 \\
\hline 16 & 14.3 & 71.4 & 14.3 \\
\hline 17 & 66.7 & 19.0 & 14.3 \\
\hline 18 & 47.6 & 28.6 & 23.8 \\
\hline
\end{tabular}

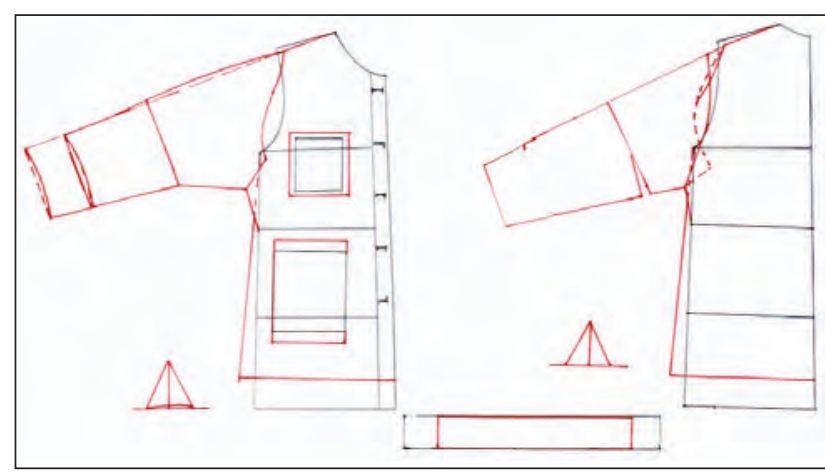

Fig. 4. Pattern modifications of work uniform (front and back part)

(2) 
Since the majority of the people wearing a work uniform were not pleased with the removable sleeves, a dolman sleeve arm with an extra part in it that came from the body was prepared. Dolman sleeve arm with an extra part in it provides more movement comfort compared to dolman sleeve arms without an extra part. While drawing this dolman sleeve form, the armhole height and sleeve length were shortened, the wrist width was narrowed, and the armhole width was increased.

\section{CONCLUSION}

In this study, it was evaluated fit of work uniforms worn by people working in laboratories and workshops. According to the research results, the majority of the individuals wearing a work uniform believe that their work uniforms were not suitable for their body movements.

Some modifications were made on the basic work uniform pattern based on the data obtained from research parameters.

\title{
BIBLIOGRAPHY
}

[1] Sweeney, M.M., Branson, D.H. Sensorial comfort, Part I: A psychophysical method for assessing moisture sensation in clothing, In: Textile Research Journal, 1990, vol. 60, no. 7, pp. 371-377.

[2] Liao, X., Hu, J., Li, Y., Li, Q., Wu, X. A Review on fabric smoothness-roughness sensation studies, In: Journal of Fiber Bioengineering \& Informatics, 2011, vol. 4, no. 2, pp. 105-114.

[3] Öner, E., Okur, A. Materyal, üretim teknolojisi ve kumaş yapısının termal konfora etkileri, In: Journal of Textiles and Engineer, 2010, vol. 17, no. 80, pp. 20-29.

[4] Li Y. The science of clothing comfort. In: The Textile Institute Publications, Textile Progress, Manchester, 2001, vol. $31(1 / 2)$, p.138.

[5] Marmaralı, A., Özdil, N., Kretzschmar, S.D. Elastik iplikli düz örme kumaşların ısıl konfor özellikleri, In: Tekstil ve Konfeksiyon, 2007, vol. 17, no. 3, pp. 178-181.

[6] Olaru, S., Filipescu, E., Niculescu, C. Morphological indicators for characterization of women thorax and basin shape, for garment design in customized system, In: Industria Textila, 2011, vol. 62, no. 6, pp. 289-295.

[7] Choi, M.S., Ashdown S.P., 2002, The design and testing of work clothing for female pear farmers, In: Clothing and Textiles Research Journal, vol. 20, pp. 253-263.

[8] Schofield, N.A., Ashdown, S.P., Hethorn, J., LaBat, K., Salusso, C.J. Improving pant fit for women 55 and older through an exploration of two pant shapes, In: Clothing and Textiles Research Journal, 2006, vol. 24, pp. 147-160.

[9] Ho SS., Yu W., Lao, TT., Chow DHK., Chung JW., Li, Y. Comfort evaluation of maternity support garments in a wear trial, In: Ergonomics, 2008, vol. 51, no. 9, pp. 1376-1393.

[10] Çoruh, E. An investigation of the ergonomics of jeans, In: Tekstil ve Konfeksiyon, 2009, vol. 19, no. 3, pp. $248-254$.

[11] Çivitci, Ş., and Çakmak, Z.,F., 2009, Effects of fabric constructions on pattern design in women trousers, In: Tekstil ve Konfeksiyon, vol. 19, no. 4, pp. 316-322.

[12] Çoruh, M., Vural, T., Çoruh, E. A scale development study to evaluate the physical comfort of denim jeans, In: Tekstil ve Konfeksiyon, 2011, vol. 21, no. 1, pp. 77-81.

[13] Komarkova, P., Glombikoca, V. The effect of anatomical changes in the female body during pregnancy on pattern designs for maternity wear, In: Tekstil ve Konfeksiyon, 2013, vol. 23, no. 4, pp. 409-415.

[14] Utkun, E. Body movement comfort performances of shirts intended for bellied males, In: Journal of Textiles and Engineer, 2014, vol. 21, no. 96, pp. 10-19.

\section{Authors:}

\author{
EMINE UTKUN ${ }^{1}$ \\ NEZLA ÜNAL ${ }^{2}$ \\ Pamukkale University \\ Buldan Vocational Training School \\ ${ }^{1}$ Program of Fashion Design \\ ${ }^{2}$ Program of Apparel Manufacturing Technology \\ Buldan 20400, Denizli, Turkey \\ e-mail: eutkun@pau.edu.tr, nezlaunal@pau.edu.tr
}

Corresponding author:

EMINE UTKUN

eutkun@pau.edu.tr 


\section{The influence of design and aesthetics elements in choosing clothing}

Influența elementelor de design şi estetică în alegerea îmbrăcămintei

Pe piața produselor de design vestimentar, elementele de design și estetică reprezintă un factor important în procesul decizional al cumpărătorilor. Prezentul articol evidențiază influențele acestor elemente pe piața modei din România. În acest sens, a fost efectuată o cercetare de piață cantitativă pe un eșantion de 496 subiecți de sex feminin, având ca scop identificarea elementelor de design și estetică în alegerea îmbrăcămintei la modă. Pe baza rezultatelor obținute, au fost prezentate stilurile de modă preferate, combinația dintre croială și materialele utilizate sau culorile predominante, elemente care definesc specificul pieței interne de îmbrăcăminte.

Cuvinte-cheie: cercetare de piață, mesaj vizual, industria modei, tendințe, stil de modă

\section{The influence of design and aesthetics elements in choosing clothing}

On the fashion products market, the design and aesthetics elements are an important factor in the buyers' decision process. The present article highlights the influences of these elements on the fashion market from Romania. In this respect, a quantitative market research was conducted on a sample of 496 female subjects, having the identification of the design and aesthetics elements' role in choosing fashion attires as a target. Based on the results obtained, the favorite fashion styles, mixtures between the cut and the materials used or predominant colors, elements that define the specific of domestic clothing market were shown.

Keywords: market research, visual message, fashion industry, trends, fashion style

\section{INTRODUCTION}

Fashion design has several challenges on producers of clothing products because it is based very often on personal preferences, established more on product appearance than on its utility. Elements of design and aesthetics are among the most important features of any product and, as marketing tools, influence to a large extent the success or failure of a product.

That is why, the representatives of companies producing clothing products must continuously monitor the behavior of target customers, taking into account the reasons for choosing a certain product over another, the way in which the public assess clothing products and the way they purchase them.

Roland Barthes defines fashion as a complex system of meanings, in which the clothes are visual elements which can be "read" as a text [1]. He states that a clothing product has three important dimensions: the first one is technological, namely the creation of any type of clothing, from concept to finite product; the second dimension is the spatial one, consisted of shapes, lines, surfaces and colors; the last is the verbal dimension, which refers to visual message and clothing product as an experience in a certain context. Therefore, clothing products, in comparison with other products, have a higher symbolic meaning for consumers, because through the story they tell and the context in which they are worn, they give a status to the wearer and influence the consumer lifestyle to a higher or lower extent, depending on the interest in fashion trends [2-3]. That is why, product innovation and communication are essential for gaining an important place in the consumer's mind [4]. However, without a function and utility, the significance of a clothing product is insufficient to acquire a fashion product. According to James Laver, the three functions of the clothing products are the following: utility - considered as the least important factor, hierarchy - status given by wearing certain clothes and seduction - clothing must favor the body and to fit the person wearing the clothes in the general pattern of attraction specific to the historic and social framework [5]. A successful fashion item combines all these functions through specific elements of design and aesthetics.

\section{THE FASHION MARKET}

The fashion industry is among the most complex, varied and dynamic activity fields at a global level, with approximately 75 million employees all over the world [6]. Over time, the global fashion market has passed different evolution stages regarding the elements of design and aesthetics of items and the market' functioning and organization. The evolution of the fashion product elements of design and aesthetics is closely linked to the evolution of the fashion market, facilitating the cooperation relationships between cultures and different economic systems. With a few exceptions, the merit to launch creative trends with global impact and to offer technological and organizational solutions valid until today in the fashion 
industry is assigned to French haute-couture designers [7]. Also, while design and creativity are considered the strength of the fashion market from France, the Italian market is valued for manufacturing, and the American one for the brand identity management [8].

At the moment, in Romania, there are more than 3000 producers of clothing products, and the market can be divided in several sectors: leather clothing products, fur products, woven or crocheted items, professional wardrobe items, special occasion items and underwear items [9]. Among the most important producers on the market are Modexim, founded in 1991, producing clothing products for brands as Steilman, H\&M and MaxMara, and the company Conflux, founded in the same year after the reorganization of the Company of Garments and Knitwear Bucharest, cooperating nowadays with Emporio Armani, Alain Figaret, Sonia Rykiel and many other international companies [10]. Other Romanian companies with a long history on the Romanian market and a good evolution are Catex, Tex Model Grup and Held Fashion.

\section{RESEARCH METHODOLOGY}

In order to achieve the article's objectives, a quantitative market research was conducted. This was made from the point of view of fashion market companies which identified an important marketing opportunity to diversify the product range and want to find out more information on the customers' behavior and their attitude toward the fashion product elements of design and aesthetics.

The main objective of this research is to determine the role of the design and aesthetics elements in choosing attires among women from Romania.

The marketing research started from the following hypotheses:

1. At least $70 \%$ of the women from Romania are interested in fashion trends.

2. An elegant clothing style is generally preferred.
3. The most important design and aesthetic elements of clothing products are the material and color.

4. Most women from Romania consider that, for clothing products, appearance and comfort are equally important.

The quantitative research methodology was based on interviewing 496 persons, females from Romania, using a survey and a questionnaire as a data collection tool. The data collection technique called CAWI Computer Assisted Web Interviewing was used, the method by which the questionnaire is posted on a web page, the respondent filling in the answers directly in the browser. For this method there is no need for additional configurations and there is no need for a program to be installed, the browser offered by the operating system being enough. The period in which this study was made is December 2016 - February 2017. Data collection was based on a questionnaire which includes 27 questions, of which 5 are for subjects' characterization.

After information collection with the help of the questionnaire, the data statistical processing was made with the SPSS system (Statistical Package for Social Sciences). The first stage was to define the relevant variables of the research. After that, the answer options were coded for facilitating data introduction in the computer. Coding was achieved depending on each question and the scale used for that question. SPSS database was filled in after the introduction of all questionnaires, and finally, data was centralized as frequency tables and graphs [11].

Of 496 respondents, $36.1 \%$ have secondary education and $63.9 \%$ have higher education, $43.5 \%$ of the respondents are in the age group 20-30 years, and a close percentage, namely $37.1 \%$ of the total sample are between 31 and 40 years old. The lowest percentage of the sample $(19.4 \%)$ is represented by the customers with the age between 41 and 50 years (table 1 and figure 1).

According to data presented in table 2 and figure 2, most responses $-43.5 \%$ of the total sample - show

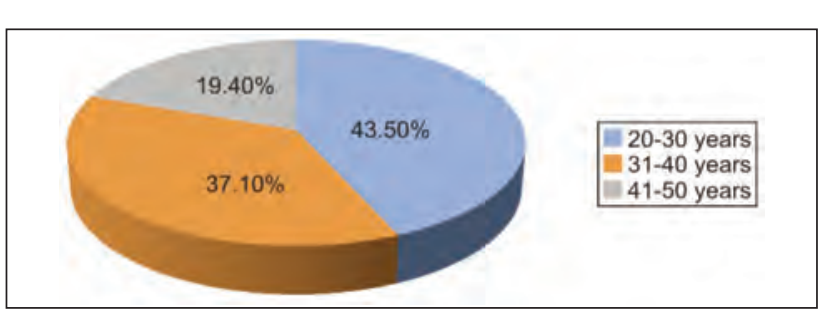

Fig. 1. Respondents' age

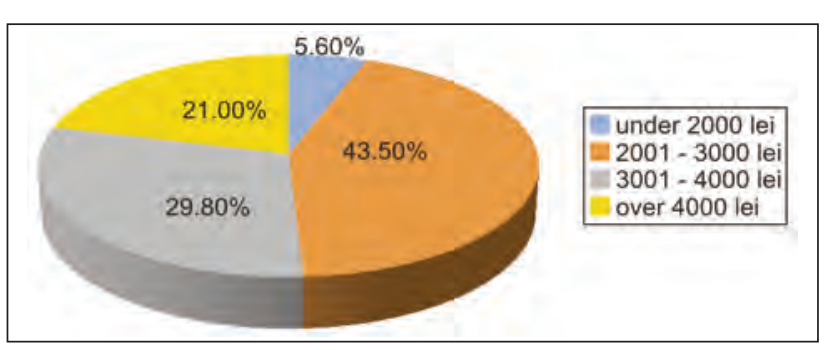

Fig. 2. Respondents' income

\begin{tabular}{|r|l|r|r|}
\hline \multicolumn{3}{|c|}{ Table 2 } \\
\hline \multicolumn{3}{|c|}{ RESPONDENTS' INCOME } \\
\hline \multirow{3}{*}{ Valid } & under 2000 lei & Frequency & Percent \\
\cline { 2 - 4 } & $2001-3000$ lei & 54 & 5.6 \\
\cline { 2 - 4 } & $3001-4000$ lei & 37 & 43.5 \\
\cline { 2 - 4 } & over 4000 lei & 26 & 29.8 \\
\cline { 2 - 4 } & Total & 124 & 100.0 \\
\hline
\end{tabular}


a monthly income level between 2000 and 3000 lei, while $29.8 \%$ of the answers show a monthly income level between 3000 and 4000 lei, and $21 \%$ of the respondents have a monthly average income over 4000 lei.

\section{RESEARCH RESULTS}

The research has shown a lot of information, further being presented the most relevant for the issues taken into account.

According to data obtained, of 496 members of the sample, 436 confirmed that they have an increased interest in fashion trends, while 60 members answered that they have no interest in fashion. There were no non-answers recorded. For the first question, the percentage of affirmative answers was $87.9 \%$ (table 3 and figure 3 ).

The question regarding the favorite clothing style is based on a variable measured with a nominal scale with single choice. Distribution of answers is presented in table 4.

From data analysis we can notice that $45.2 \%$ of the respondents considered the elegant fashion style as favorite. Also, the casual style was preferred by $30.6 \%$ of the respondents. The bohemian and conservative styles were preferred in equal percentages, of $11.3 \%$, by the sample's respondents. The eclectic style is preferred by only $1.6 \%$ of the respondents in this case. We mention that there were no nonanswers at this question. It can be noticed that the distribution of answers is not uniform, with a significant concentration on the elegant fashion style.

In table 5 it can be noticed that most of the answers show the preference for straight tailoring fashion products, made of viscose. Another combination cutmaterial preferred by interviewed customers show the preference for fashion products with straight tailoring, made of veil. The third place in preferences ranking at the level of the analyzed sample is taken by the knit products, with straight tailoring. The other mixtures between cut and material are preferred by a lower number of respondents.

Regarding the purchase frequency for these products, it can be noticed that $33.9 \%$ of the respondents buy clothing 3-4 times a year, while only $9.7 \%$ of the respondents buy clothing more than 4 times a year. $27.4 \%$ stated that they buy clothing only twice a year, and $29 \%$ of the interviewed persons buy clothing only once a year (table 6).

The research pursued the ordering of the design and aesthetics elements of fashion products taking into account their importance in the purchase decision (table 7).

Table 3

\begin{tabular}{|c|c|c|c|}
\hline \multicolumn{4}{|c|}{$\begin{array}{c}\text { SUBJECTS' INTERESTS ON CLOTHING MARKET } \\
\text { TRENDS }\end{array}$} \\
\hline & & Frequency & Percent \\
\hline \multirow[t]{3}{*}{ Valid } & Yes & 436 & 87.9 \\
\hline & No & 60 & 12.1 \\
\hline & Total & 496 & 100.0 \\
\hline
\end{tabular}

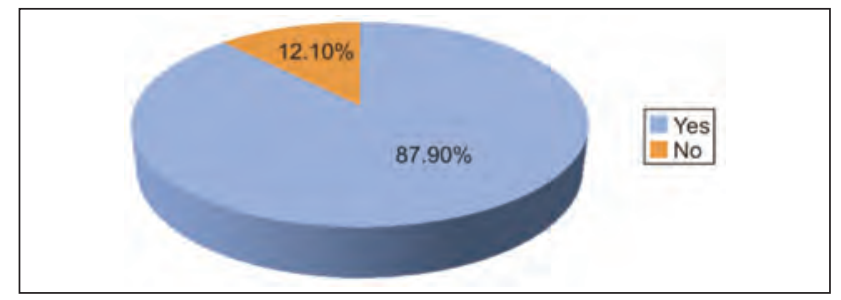

Fig. 3. Subjects' interests on clothing market trends

\begin{tabular}{|l|l|r|r|}
\hline \multicolumn{3}{|c|}{ FASHION STYLE } \\
\hline \multirow{3}{*}{ Valid } & Frequency & Percent \\
\hline \multirow{7}{*}{} & Bohemian & 56 & 11.3 \\
\cline { 2 - 4 } & Casual & 152 & 30.6 \\
\cline { 2 - 4 } & Conservative & 56 & 11.3 \\
\cline { 2 - 4 } & Eclectic & 8 & 1.6 \\
\cline { 2 - 4 } & Elegant & 224 & 45.2 \\
\cline { 2 - 4 } & Total & 496 & 100.0 \\
\hline
\end{tabular}

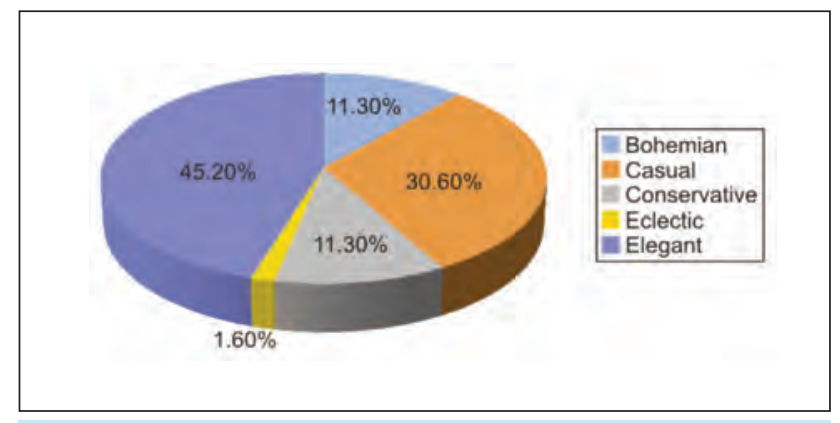

Fig. 4. Fashion style

THE CORRELATION BETWEEN THE CUT AND THE PREFERRED MATERIAL IN CLOTHING

\begin{tabular}{|l|l|r|r|r|r|r|}
\hline \multicolumn{2}{|c|}{} & \multicolumn{1}{c|}{ Lace } & \multicolumn{1}{c|}{ Knit } & \multicolumn{1}{c|}{ Viscose } & \multicolumn{1}{c|}{ Veil } & \multicolumn{1}{c|}{ Total } \\
\hline \multirow{3}{*}{ Cut type } & Draped tailoring & 32 & 12 & 16 & 80 & 140 \\
\cline { 2 - 7 } & Straight tailoring & 28 & 68 & 96 & 40 & 232 \\
\cline { 2 - 7 } & A tailoring & 12 & 4 & 24 & 16 & 56 \\
\cline { 2 - 7 } & V tailoring & 20 & 20 & 20 & 8 & 68 \\
\cline { 2 - 7 } & Total & 92 & 104 & 156 & 144 & 496 \\
\hline
\end{tabular}




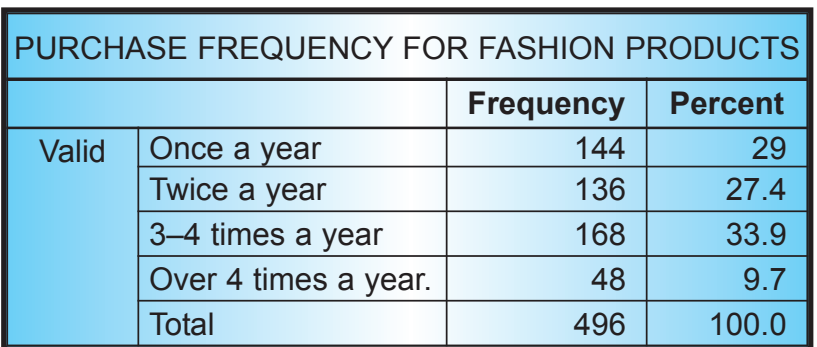

The results have shown that, on the first place, regarding the importance as a design and aesthetic element of the fashion products is the material, with an average of assessments of 1.35 points, followed

Table 7

\begin{tabular}{|c|c|c|c|c|}
\hline \multicolumn{5}{|c|}{$\begin{array}{c}\text { THE IMPORTANCE OF DESIGN AND AES } \\
\text { ELEMENTS IN PURCHASE }\end{array}$} \\
\hline \multicolumn{5}{|c|}{ DESCRIPTIVE STATISTICS } \\
\hline & $\mathrm{N}$ & Minimum & Maximum & Mean \\
\hline & 122 & 1 & 3 & 1.35 \\
\hline Color & 122 & 1 & 5 & 2.10 \\
\hline Cut & 123 & 1 & 5 & 2.55 \\
\hline Print & 122 & 1 & 5 & 3.33 \\
\hline Versatility & 122 & 1 & 5 & 3.84 \\
\hline Valid N (listwise) & 122 & & & \\
\hline
\end{tabular}

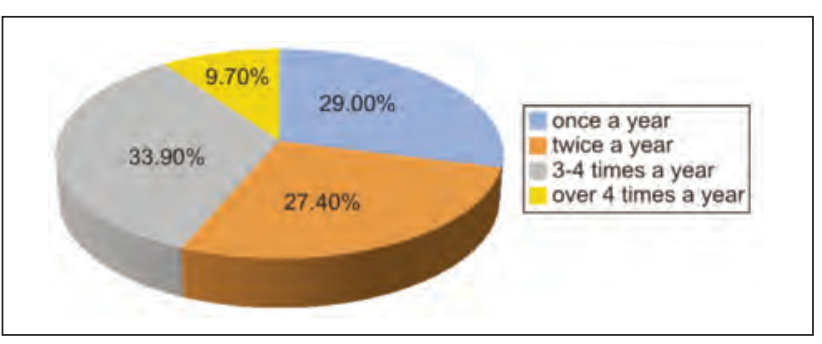

Fig. 5. Purchase frequency for fashion products

by color, with an average of 2.10 points, and cut, with the average of assessments of 2.55 points. The least important elements of design and aesthetics are considered to be the print and versatility.

Regarding the attitudes and opinions of the interviewed persons on fashion products' elements of design and aesthetics, the correlation between design and aesthetics elements was studied. Both were assessed as being the most important aspects of each attire, namely the material and color (table 8).

We notice that most preferences show the following association material-color: lace and knit of dark colors, viscose of neutral colors and veil of dark or pastel colors.

If we refer to the type of favorite colors by the interviewed persons, the analysis led to the following observations: $37.1 \%$ of the respondents have shown their clear preference towards dark colors, $33.1 \%$ have chosen pastel colors, and $25 \%$ of them have

Table 8

\begin{tabular}{|c|c|c|c|c|c|c|c|}
\hline \multicolumn{8}{|c|}{ CORRELATION BETWEEN MATERIAL TYPE AND FAVORITE COLOURS } \\
\hline & & $\begin{array}{l}\text { Dark } \\
\text { colours }\end{array}$ & $\begin{array}{l}\text { Neutral } \\
\text { colours }\end{array}$ & $\begin{array}{l}\text { Neutral colours, } \\
\text { dark colours }\end{array}$ & $\begin{array}{l}\text { Neutral colours, } \\
\text { pastel colours }\end{array}$ & $\begin{array}{l}\text { Pastel } \\
\text { colours }\end{array}$ & Total \\
\hline \multirow{4}{*}{$\begin{array}{l}\text { Type of } \\
\text { material } \\
\text { preferred }\end{array}$} & Lace & 44 & 8 & 0 & 4 & 36 & 92 \\
\hline & Knit & 48 & 28 & 4 & 4 & 20 & 104 \\
\hline & Viscose & 36 & 76 & 4 & 4 & 36 & 156 \\
\hline & Veil & 56 & 12 & 0 & 0 & 76 & 144 \\
\hline \multicolumn{2}{|l|}{ Total } & 184 & 124 & 8 & 12 & 168 & 496 \\
\hline
\end{tabular}

Table 9

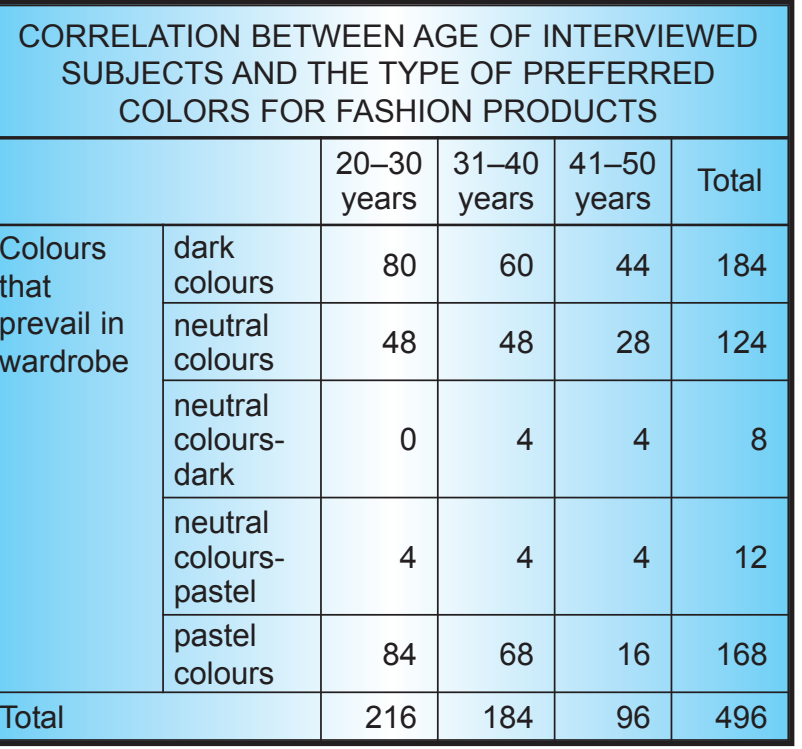

Table 10

\begin{tabular}{|c|c|c|c|c|c|}
\hline \multicolumn{6}{|c|}{$\begin{array}{l}\text { PCORRELATION BETWEEN THE AGE OF } \\
\text { INTERVIEWED SUBJECTS AND THE TYPE } \\
\text { OF MATERIAL PREFERRED FOR CLOTHING }\end{array}$} \\
\hline & & $\begin{array}{l}20-30 \\
\text { years }\end{array}$ & $\begin{array}{l}31-40 \\
\text { years }\end{array}$ & $\begin{array}{l}41-50 \\
\text { years }\end{array}$ & Total \\
\hline \multirow{4}{*}{$\begin{array}{l}\text { Preferred } \\
\text { material } \\
\text { type }\end{array}$} & Lace & 8 & 36 & 48 & 92 \\
\hline & Knit & 64 & 32 & 8 & 104 \\
\hline & Viscose & 100 & 24 & 32 & 156 \\
\hline & Veil & 44 & 92 & 8 & 144 \\
\hline \multicolumn{2}{|l|}{ Total } & 216 & 184 & 96 & 496 \\
\hline
\end{tabular}

chosen neutral colors. Taking into account that $1.6 \%$ of the customers prefer neutral and dark colors, and $2.4 \%$ of them prefer neutral colors and pastel colors, it can be said that the distribution of answers is relatively uniform (figure 5). 
Another important issue that was approached in this research is the correlation between the age of the interviewed subjects and the type of favorite colors for all clothing (table 9) and the correlation between the age of interviewed subjects and the type of material preferred by them (table 10).

Data obtained shows a unit trend, for all the groups, the pastel colors being preferred by the respondents aged 20-30 years old, and for the respondents aged 31-40 years old. Only the respondents aged 41-50 years old prefer neutral colors, against pastel colors. Regarding the results obtained from the correlation analysis between the subjects'age and favorite material, significant differences among the identified age groups can be noticed. The customers aged 20-30 years old prefer viscose (46.3\% of them), knit $(29.6 \%)$, then veil $(33 \%)$, and knit and veil had an equal percentage in preferences ranking, namely $8.5 \%$. In the age group $31-40$ years old, the veil was designated as the preferred material by half of the customers of this age segments, being followed, by lace $(19.6 \%)$, knit $(17.3 \%)$ and viscose $(13.1 \%)$.

\section{CONCLUSIONS}

The design and aesthetics elements are essential factors for the favorable evolution of each product on a certain market, but clothing products belong to a special product category. One of the reasons is the fact that the fashion market is characterized by a rapid pace of change, imposing the fashion producers to bring new visual elements with each new collection launched. According to local or international trends, designers constantly modify certain design and aesthetic elements of fashion products - colors, materials, cuts, prints - or reinvent them, trying to surprise positively the target audience.

Another challenge facing the fashion industry companies is the extremely high degree of subjectivity involved in the purchase decision of the product. The design and aesthetics elements of a fashion product must create a functional whole, equally comfortable and attractive. Otherwise, the defect or fault of one of the design and aesthetic elements outshines the rest of the elements.

The producers' success on this market is dependent, to a high extent, on the ongoing analysis of the target customers' preferences, the changes assessed allowing them to differentiate on this extremely complex market, to continuously innovate and to actively contribute to the education and influence of customers'preferences and behaviors.

\section{BIBLIOGRAPHY}

[1] Barthes, R. The fashion system, University of California Press, Berkeley, 1990, p. 8.

[2] Escalas, J.E., Bettman, J.R. Self-Construal, reference groups and brand meaning, In: Journal of Consumer Research, 2005, vol. 32, December, pp. 378-389.

[3] McColl, J., Moore, C. An exploration of fashion retailer own brand strategies, In: Journal of Fashion Marketing and Management, 2011, vol. 15, no. 1, pp. 91-107.

[4] Madar, A. Elements of design and aesthetics on the beer market in Romania. Case Study: Tuborg, In: Bulletin of the Transilvania University of Braşov, Series V: Economic Sciences, 2015, vol. 8(57), no. 2, p. 86.

[5] Laver, J. Pleasures of life, vol. 5, Clothes, Horizon Press, 1952, p. 23.

[6] Stotz, L., Kane, G. Global garment industry fact sheet, available at: https://www.cleanclothes.org/resources/ publications/factsheets/general-factsheet-garment-industry-february-2015.pdf, accessed 14 February 2017.

[7] Djelic, M.L., Ainamo, A. Coevolution of new organizational forms in the fashion industry: A historical and comparative study of France, Italy, and the United States, In: Organization Science, 1999, vol. 10, no. 5, pp. 622-637.

[8] Crane, D. Globalization, organizational size, and innovation in the French luxury fashion industry: Production of culture theory revisited, In: Poetics, 1997, vol. 24, no. 6, pp. 393-414.

[9] http://www.zf.ro/companii/retail, accessed 27 January 2017.

[10] http://www.businessmagazin.ro/analize/comert/cine-face-legea-pe-piata-de-moda-din-romania-si-cu-ce-vinnewcomerii-15063387, accessed 27 January 2017.

[11] Costantin, C. Analizadatelor de marketing: aplicații în SPSS, C.H. Beck, București, 2012.

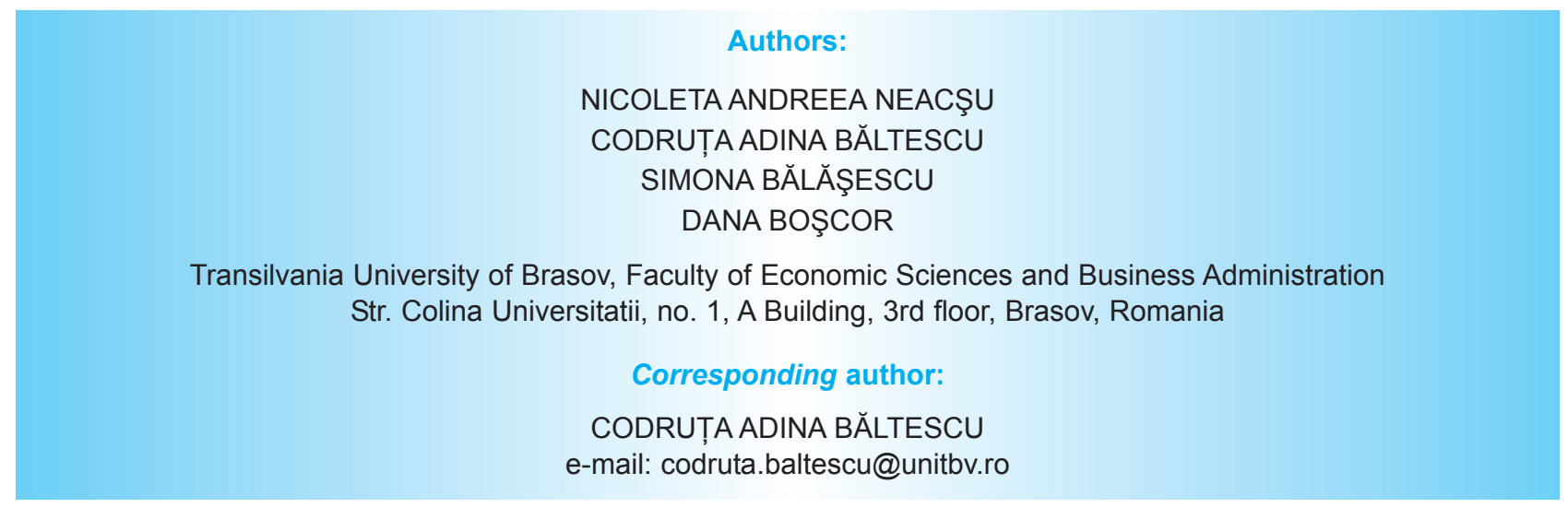




\title{
Consumer perception concerning the trade of counterfeit clothing brands in Romania. A pilot study - Southern region and Bucharest
}

\author{
DOI: $10.35530 / 1 T .068 .05 .1366$
}

\section{REZUMAT - ABSTRACT}

\section{Percepția consumatorilor privind comercializarea în România a brandurilor de haine contrafăcute.} Studiu pilot - regiunea de Sud și Bucureşti

\begin{abstract}
Contrafacerea este unul dintre cele mai vechi fenomene, care a apărut odată cu piața și cu dorința oamenilor de a se îmbogăți. Dacă o perioadă îndelungată contrafacerea a fost privită ca nefiind un fenomen îngrijorător, deoarece producția se realiza în spații mici, clandestine și în cantități relativ reduse, astăzi amploarea fenomenului este demnă de luat în calcul. În prezent, contrafacerea profită de cele mai noi realizări ale științei și tehnicii, transformându-se într-un fenomen cu multiple fațete. Producătorii de falsuri și-au extins semnificativ aria - de la ceasuri, textile, haine, electronice, electrocasnice, telefoane mobile, produse cosmetice, medicamente, până la jucării și produse alimentare. Pornind de la astfel de elemente și de la efectele negative pe care contrafacerea le are asupra companiilor, consumatorilor și statului, autorii acestui articol își propun să evidențieze cu ajutorul unui studiu empiric (pe bază de chestionar) principalele aspecte ale comportamentului consumatorului român din Bucuresti și regiunea de sud a României, cu scopul identificării unui set de măsuri menite să conducă la diminuarea acestui flagel. Rezultatele obținute în urma studiului, din păcate, arată că, în ciuda efectelor negative, românii din capitală și din partea de sud a țării achiziționează produse contrafăcute în mod conștient, din diverse motive, care vor fi prezentate în secțiunile lucrării.
\end{abstract}

Cuvinte-cheie: contrafacere, comportamentul consumatorului, măsuri anti-contrafacere, industria de confecții

Consumer perception concerning the trade of counterfeit clothing brands in Romania. A pilot study - Southern region and Bucharest

Counterfeiting is one of the oldest phenomena that emerged with the market and people's desire to get rich. If an extended period counterfeiting has been regarded as not being a serious problem because the production supposed relatively small quantities and was realized in small and clandestine spaces, nowadays the extent of the phenomenon is worthy be taken into account. Currently, counterfeiting takes advantage of the latest achievements of science and technology, transforming itself into a multifaceted phenomenon. Lately, the producers of counterfeits have significantly expanded their area - from watches, textiles, clothing, electronics, mobile phones, cosmetics, medicinal products, to toys and food. Based on such elements and on the negative effects that counterfeiting has on companies, consumers and state, the authors of this article aim to highlight, by means of an empirical study (based on a survey), the main features of Romanian consumer behavior in the capital city and southern region of Romania, with the purpose of identifying a set of measures aiming at reducing this scourge. The findings of the conducted study unfortunately shows that, despite the negative effects of the counterfeiting, Romanians from the capital and from the south of the country deliberately purchase counterfeit products, for various reasons, which will be outlined in the sections of this paper.

Keywords: counterfeiting, consumer behavior, anti-counterfeiting measures, clothing industry

\section{INTRODUCTION}

Counterfeiting is an issue as old as the world exists. Examples that history offers us are numerous. Phillips showed how in $27 \mathrm{BC}$, corks used for wine amphorae, in which it was transported, wore a counterfeit seal so as to pass a local wine as an imported wine in order to sold it at a higher price [1]. The Roman philosopher Pliny the Elder (AD 23-79) stated that counterfeit coins were highly desirable objects among contemporary collectors, who were willing to pay significant sums for them [2]. Counterfeiting practically exists since markets have emerged and it was expanded with the mass production sold on legal markets.

The phenomenon of counterfeiting is one that has aroused and still arouses a strong interest both in academia and the general public. From the agreement of generating a universally accepted definition and of identifying the required measures to eradicate counterfeiting, the specific issues of studying it still require clarification. Typically, counterfeiting is defined as "unauthorized representation of a registered trade mark in order to deceive the buyer, who thinks that he acquires the original good" [3]. The definitions listed over time were based on two assumptions: 1) counterfeit goods are intended for consumers aware that they are purchasing fakes; 2) counterfeit goods are purchased by people who think they are buying the originals.

Lai and Zaichkowsky consider that as important as the definition of counterfeiting is also the definition of a counterfeit product. They show that "a counterfeit product is a $100 \%$ copy, typically having a lower quality, although not always" [4]. 
In the past, counterfeiting seemed to be the prerogative of some relatively small companies or of producers who owned small sweatshops. During the last 15-20 years, counterfeiting switched to "heavyweight category" in the sense that it has become the preserve of large companies, well organized and with international distribution networks [5].

The emphasis of the exact figures on counterfeiting is impossible because of the illegal nature of the activity performed. Over time, however, various organizations have tried to make estimations. Thus, the OECD estimated for 2007 a value of 250 billion dollars for counterfeit and pirated products, but this value did not include those produced and consumed in the same country or non-tangible digital products [6]. For 2015, the estimated value was a worrying one -1.77 trillion dollars [7]. In the US, the expected annual impact is enormous - 200 trillion dollars [8]. In the UK, based on a survey, the annual consumption of counterfeit clothes and shoes was approximated at 5.4 billion dollars [9].

The goods in question are of the most diverse - from pharmaceuticals to clothing and shoes. In France, for example, most often confiscated counterfeit products are the shoes, representing $21 \%$ of all seized articles, followed by clothes and watches. In Germany, clothes account for $90 \%$ of all counterfeits [10].

Unfortunately, all over the World, the trade with fakes exists and its value tends to increase. European Commission identified for the European Union that the number of counterfeit goods detained in customs increased by $15 \%$ in 2015 comparing to 2014 , registering the amount of 650 mil. Euro. The main country of provenance for the fakes remains China with $41 \%$ of the total of counterfeit trade in the EU. According to the Report on EU Customs enforcement of intellectual property rights. Results at the EU border: "Benin was the originating country of a large amount of foodstuff, while Mexico was the top source for counterfeit alcoholic beverages and Morocco for other beverages. Malaysia was in the lead for toiletries, Turkey for clothing, Hong Kong for counterfeit mobile phones and accessories, memory cards, computer equipment, CDs and DVDs and lighters. Montenegro was the biggest originator of counterfeit cigarettes, while India topped the list for medicines" [11].

The same Report shows the fact that Romania follows the global trend. Here the trade of fakes has prospered - the number of articles detained in customs increased in 2015 by $53 \%$ comparing with 2014, from 3.076.236 to 4.693 .180 counterfeit goods [12]. For Romania, the originating countries of fakes are the same as those recorded for the EU. Unfortunately, the figures are not public and we have only some estimates. Thus, for 2009 about $28 \%$ of traded goods were estimated to be counterfeit and approximately $50 \%$ of identified counterfeits came from China according to the press releases of the Romanian Anticounterfeiting Association [13]. Although, there are a lot of Romanian companies producing original goods, the lower price of fakes makes the difference in choosing them.
Nowadays, there is no reason to believe that the phenomenon will disappear, quite the contrary. The advent of the Internet and its use in mass appear to be helpful for distributors of counterfeit products. In the past manufacturers of counterfeit products relied on street vendors and on markets that were functioning only by night; currently the Internet provides the ease of distribution [14]. According to reports carried out at the international level, it is estimated that in 2008 there was an increase in the sale of counterfeit goods by $45 \%$ and $80 \%$ from this is due to online sales [15].

Based on such statistics, this paper sets as a main objective emphasizing the Romanian consumer perception (whereas the extent of this phenomenon is significant in Romania) on the selling and buying of counterfeit clothes in order to identify some potential measures to reduce the scale of counterfeiting.

\section{COUNTERFEITING IN THE SCIENTIFIC LITERATURE}

Over the centuries, numerous authors were concerned about this issue. Since the twentieth century, the extent of the phenomenon seems to have increased mainly thanks to new techniques and technologies. Thus, among those who wrote about general aspects of trade with counterfeit products in the new context, have been Kaikati and LaGarce [16], Hansen [17], Higgins and Rubin [18], Grossman and Shapiro [19] etc. The articles published in the last two centuries usually started by identifying the causes and the circumstances of the production of counterfeit goods and went up to the presentation of the profile of producer and/or purchaser of counterfeits.

It has been found in the scientific literature that, usually, consumers of counterfeit products are divided into two broad categories [20].

In the first category there are included those who purchase counterfeit products without realizing that products are not genuine. In this case, the authors indicate the need for better information on the means that can be used to distinguish a fake from an original product [21]. The second category is composed of individuals who deliberately are purchasing counterfeits for various reasons. In this category there are several subcategories. Thus, there are consumers who buy counterfeit products because they do not have the financial means to buy the originals. They are attracted by the intangible benefits of wearing brands such as image and prestige. For some experts, such customers deserve some leniency, resulting from the fact that the financial loss generated by some "lost" sales in the case of the producers of originals is limited. One could even argue that they are additionally promoting the products, increasing the overall awareness of the brand to new customer segments [22]. Among them there are also those willing to purchase brand image without being interested in quality [23]. This explains why brands such as Gucci, Prada, Chanel, Burberry, Louis Vuitton and Cartier are the most frequently counterfeited [24]. 
Another subcategory of consumers is represented by those who can afford the originals, but not always choose to buy them. It's about those who own simultaneously originals and counterfeits. Counterfeit choice for this category is not generated by low income, but by the desire to own fakes. The counterfeit product may be preferred for various reasons such as: fun, pleasure and excitement to purchase [25], certain circumstances - for example to protect the original while traveling [26, 27].

Lastly, there is a group of brand loyal consumers who see the spread of counterfeits as being harmful to their personal relationship with the brand. They may choose to purchase once or twice a fake, but after this, they eventually abandon the purchase of the brand in question, since the expected exclusivity is alleviated by the wide availability of imitation that anyone can afford [28].

Many times when dealing with consumers of counterfeit goods, the ladies are brought to the fore, because, as Thorstein Veblen said "the queen of ostentatious consumption is the woman" [29]. She decides to purchase counterfeit goods for the same reasons that urge her to purchase luxury goods: personal satisfaction and impressing others, reasons that can be found also in the case of gentlemen [30]. Summarizing, the conscious purchasing of counterfeit products can occur because of the existence of three reasons [31]: accessibility of prices and/or preference for certain product features [32], social and cultural influence [33] and socioeconomic status of the consumer [34].

The categories of consumers mentioned above can be easily highlighted on a number of markets. If one looks at the second largest category of consumers, one can observe that one of the markets where all the above mentioned reasons can be quickly highlighted is the counterfeit clothing market. This is one of the reasons behind the choice of studying the Romanian consumer perceptions of counterfeit clothes.

\section{A PILOT STUDY ON ROMANIAN CONSUMERS' PERCEPTION OF COUNTERFEIT CLOTHES}

\section{Collecting data}

In order to emphasize Romanian consumer attitudes regarding counterfeit clothing there was conducted a pilot survey based on a sample of 395 respondents residing in the south of the country and in Bucharest. The questionnaire was distributed online (Google Forms) during the period June-July 2016; this method was chosen due to its low cost of data collection. Given the chosen collection method, about $51 \%$ of the respondents are aged between 16 and 24 years, the remaining $49 \%$ being represented by people aged between 25 and 54 years. Not frequently computer users, those aged over 54 were not present among the respondents. $71 \%$ of respondents were women and the remaining of $29 \%$ were men. The sample covers both people with secondary education and those with higher education, the percent- age being $51 \%$ for those with secondary education. The selected sample consists mostly of employed persons $(62 \%)$, the rest being represented by: students $(34 \%)$, unemployed persons $(2 \%)$ and freelancers $(2 \%) .66 \%$ of the respondents earn monthly between 800 and 2,000 lei, 13\% between 2001 and 3000 lei, the rest earning over 3001 lei.

The respondents were mostly residing in urban areas $(87 \%)$. We chose mostly the urban area on the assumption that physical trading of counterfeit clothes is developed in the cities, in squares, markets, proximity stores, trays or at various retailers selling goods under their own brand; the quality, originality and durability of the purchased goods being in this case questionable.

The conducted survey had three objectives:

1. Identifying the consumer perceptions concerning the causes which perpetuate the phenomenon of counterfeiting clothes in Romania;

2. Presenting the main features of the Romanian consumer behavior of counterfeit clothes;

3. Highlighting a set of measures to reduce/eradicate counterfeiting clothes market in Romania.

The results obtained after processing the survey can be found in the following sections.

\section{Results and discussions}

\section{Results of statistical analysis}

The study's results show that the Romanian counterfeit consumer profile is similar to the one in the literature. The Romanian buyers of counterfeit clothes are grouped in the two main categories mentioned above, in section 2, and the reasons for buying these fakes are diverse as we will see in the study. The most part of interviewed persons (85\%) think that there are counterfeited clothes traded in our country. Unfortunately $83 \%$ of respondents don't know at all or know only sometimes how to recognize original clothes (figure 1). These make us conclude that Romanians are less educated in this area.

The scientific literature shows that traditionally, consumers could identify the original products based on the country of origin. Nowadays the country of origin doesn't assure a certainty about originality because of the movement of the original clothes' production in

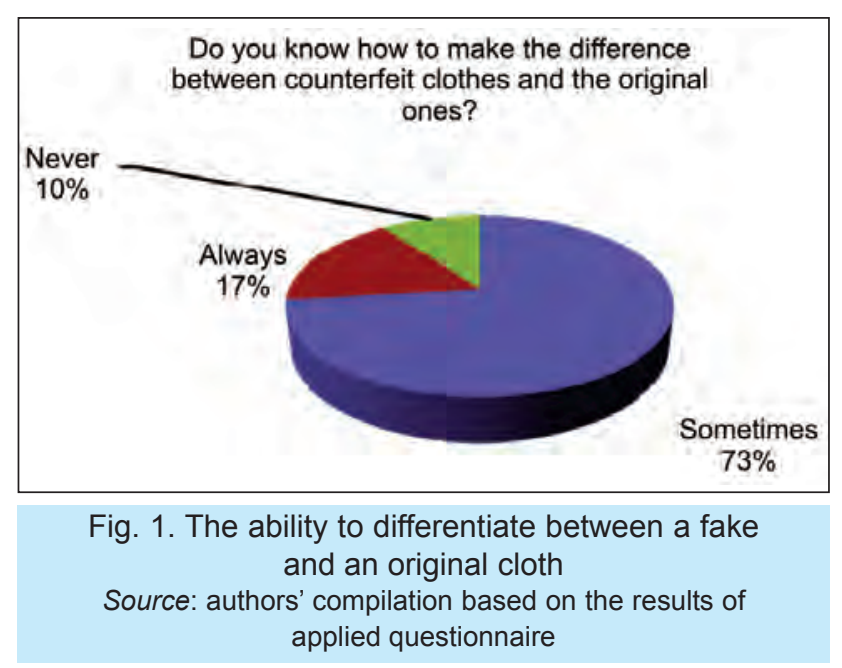


countries with a cheaper workforce. In many cases, this phenomenon has given easy access to the fake manufacturers [35]. As a result, education of the public is a very important measure in order to diminish the phenomenon.

Our research has shown that morality is not prevalent through the Romanian people, $54 \%$ of the respondents admitting that they have bought counterfeited clothes although they knew what type they are (figure 2). Mostly, such acquisitions are related to: convenience stores $(26 \%)$, street vendors $(14 \%)$, malls $(12 \%)$ and online $(9 \%)$. We focused on the correlation between the importance of brand and the desire of buying the product, although the persons had known that the product was counterfeited. The results showed that for $27 \%$ of the individuals the brand is "important" or "very important" (figure 3).

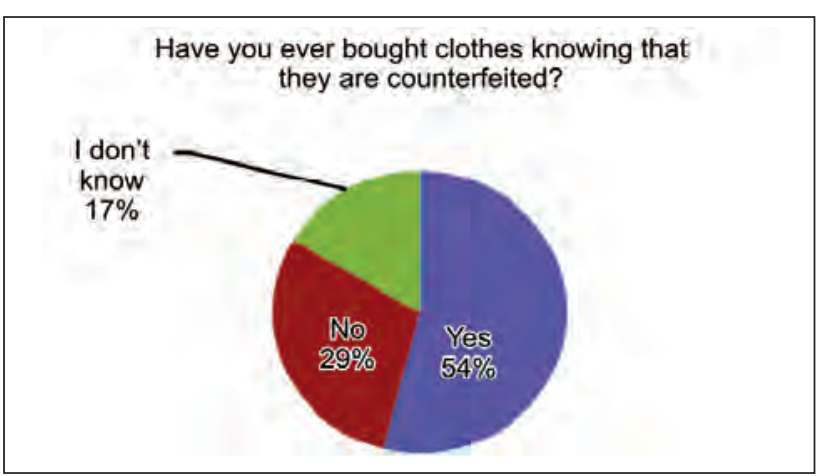

Fig. 2. Knowingly purchasing of counterfeit products Source: authors' compilation based on the results of applied questionnaire

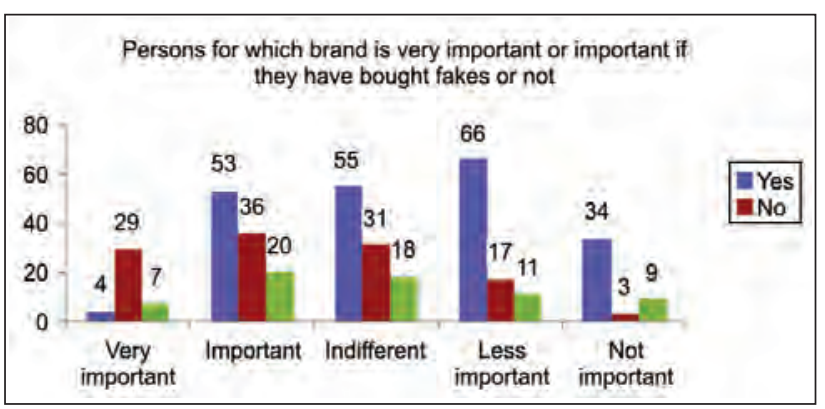

Fig. 3. Purchasing of counterfeit clothes depending on their importance for the buyer

Source: authors' compilation based on the results of applied questionnaire can't afford to buy the original product", fact that emphasized that Romanian people don't have enough knowledge regarding the means necessary to use in order to differentiate the fakes from the original products.

Among the causes identified were also found: the desire to leave the impression of belonging to a certain social class $(23.3 \%)$, the inability of recognizing counterfeit items certifying the product $(20.5 \%)$, the desire to show off (18\%), the indifference of purchasing a counterfeit mark or an original one (14.2\%), the lack of authentic products from the local market $(7.3 \%)$, the inability of recognizing the mark of clothes, even if it is famous.

The magnitude of the phenomenon is not insignificant, especially since the question "Do you have friends/acquaintances who purchase counterfeit clothing?", $79 \%$ of respondents say they have at least two acquaintances who buy these products.

Moreover, the question "If you identify a counterfeit clothing item, what do you choose to do?" showed a civic spirit almost nonexistent, $49.5 \%$ stating that they would still buy the product if they like it, 35\% saying they do not act in any way, highlighting that $4 \%$ would refer friends to buy from that merchant, while only $14.5 \%$ said they would notify the authorized agencies.

It seems, however, that among the most important factors in the perpetuation of counterfeiting is also the low income of the population. According to the National Institute for Statistics, the total income for population in 2014, as monthly average, were of 2500.7 RON per household and 937.7 RON per person [36]. Under these conditions, $54 \%$ of respondents replied that they had knowingly bought counterfeit clothing, 29\% answered "No" and 17\% - "I don't know". The percentage of those who would buy counterfeit clothes would reduce significantly if the population had higher incomes (about $28.6 \%$ according to the graph above presented).

The statement: "If I had net income per family member higher than 3,000 RON, I would still buy counterfeit clothes that are cheaper", $52.7 \%$ said that they would not purchase such items, while only $28.6 \%$ of respondents chose the response option "Yes" and $18.7 \%$ chose "I don't know" (figure 5).
In fact, this result shows that some other factors mainly influence the decision to buy or not counterfeit products. Our research identified the price as being the most important factor influencing the trade with counterfeit clothes. To the question "What do you think that are, generally, the causes of counterfeit clothes acquisition?", $88.6 \%$ of the respondents answered "the reduced price" (figure 4). From them, $40 \%$ answered (at the question "If you decided to buy/ bought counterfeit clothes, which is the motivation for choosing them?") "I like the product, I'm not interested in other details" and only $12 \%$ answered "I
What do you think are generally the main causes of counterfeit clothes? (\% of total respondents)

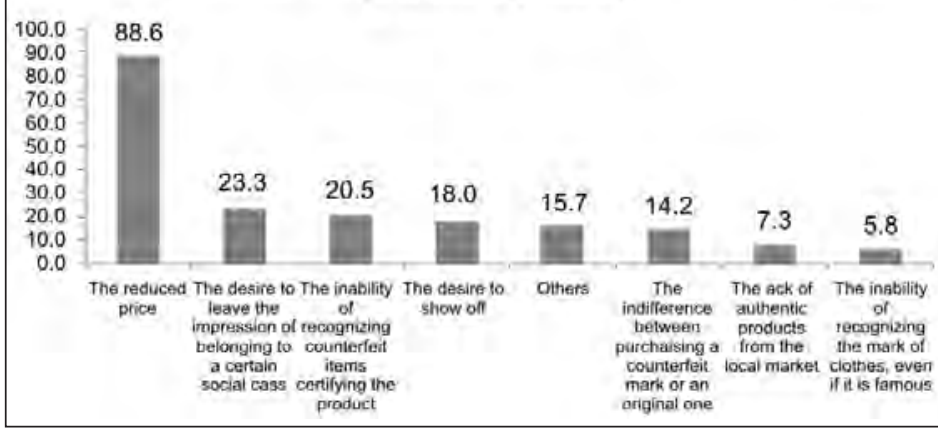

Fig. 4. Causes of buying counterfeit clothes Source: authors' compilation based on the results of applied questionnaire 


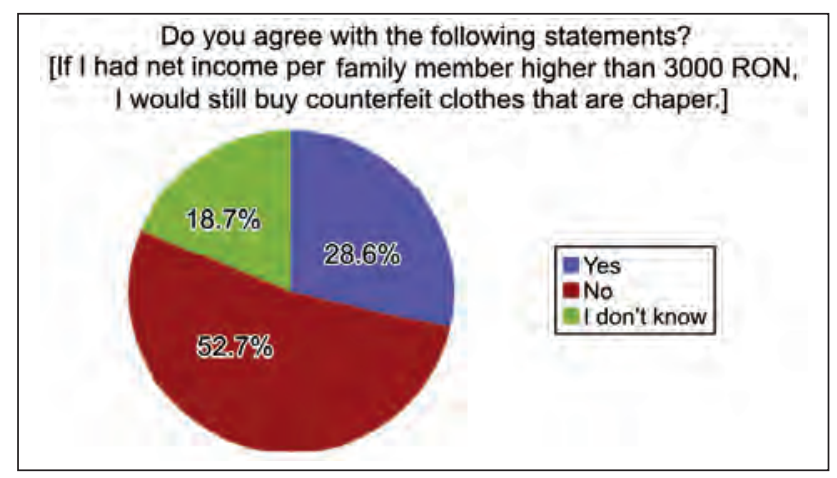

Fig. 5. What do Romanians choose depending on the income?

Source: authors' compilation based on the results of applied questionnaire

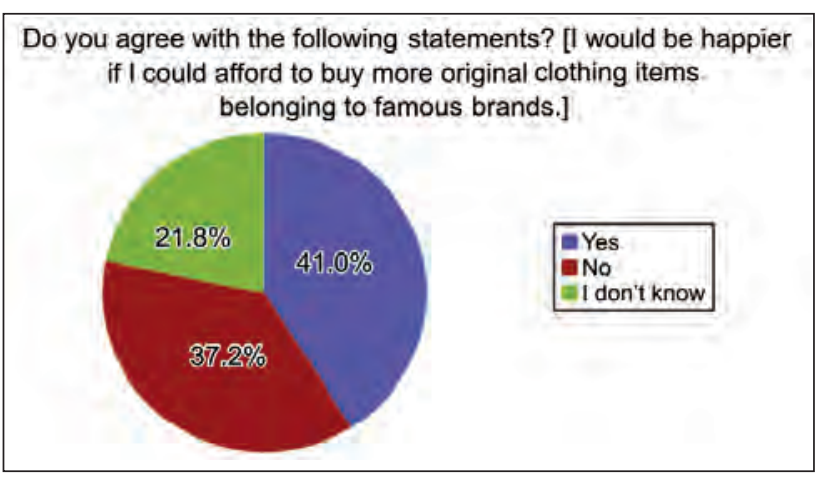

Fig. 6. The importance of brand Source: authors' compilation based on the results of applied questionnaire
The above conclusion is strengthened by the responses chosen for the statement: "I would be happier if I could afford to buy more original clothing products belonging to famous brands" (figure 6). Most of the answers were "Yes" - 41\%, given that only $29 \%$ of individuals responded initially they hadn't consciously bought counterfeit clothes. It means that there is potential to increase the number of the buyers of original clothes: $37 \%$ answered "No" and $21.8 \%$ answered "I don't know" (figure 6). Besides the mentioned above items, we can see that the Romanians' trust in the ability of the authorities responsible for reducing this phenomenon is low. When the respondents were asked whether they feel protected against the risk of counterfeit clothes on the Romanian market, $66.6 \%$ said they feel vulnerable and only $11.9 \%$ said they feel protected. The remaining respondents $(21.5 \%)$ entered in the "I don't know/no answer".

Consumer perception on the culprits who are responsible for the existence of counterfeiting clothes market in our country brings to the fore those who import and sell counterfeit products, the State through its inaction, consumers and producers of counterfeit clothes. Most respondents indicated these culprits simultaneously, as can be seen in the following chart (figure 7).

About the penalties which should be applied in this situation, $63 \%$ of respondents indicated that the importer/trader should be penalized, but also the producer of counterfeit clothing (57.2\%). Probably because of direct and consciously involvement in counterfeiting, only $16.7 \%$ from individuals believe that the buyer should be sanctioned.

Favorite sanctions of respondents refer, generally, to harsher punishments for breaking the law, improve controls, improving the legislative framework, informing consumers about the adverse effects of encouraging the purchase of counterfeit clothes etc. (figure 8). Even though it can be deducted from what was written above that the respondents are not interested in the long term effects of the trade with counterfeit clothes, it seems that most of them are aware of the medium-term effects on the industry from Romania. According to figure 9, 55.8\% from interviewed persons consider that counterfeit clothing affects textile industry in Romania. Countries, in which counterfeit clothes are sold, such as Romania, are victims of job losses in the field (it's what happened in the textile industry in Romania after '90s), the disappearance of other opportunities for marketing or a decrease of the budget revenues associated with the textile industry. In the long term, counterfeit clothes deter innovation in the field.

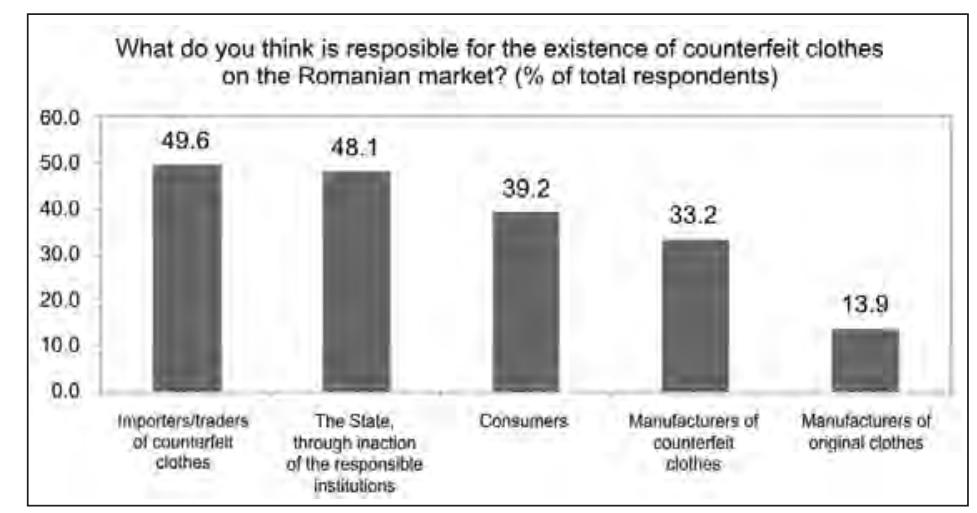

Fig. 7. Who is responsible for counterfeit clothing market? Source: authors' compilation based on the results of applied questionnaire

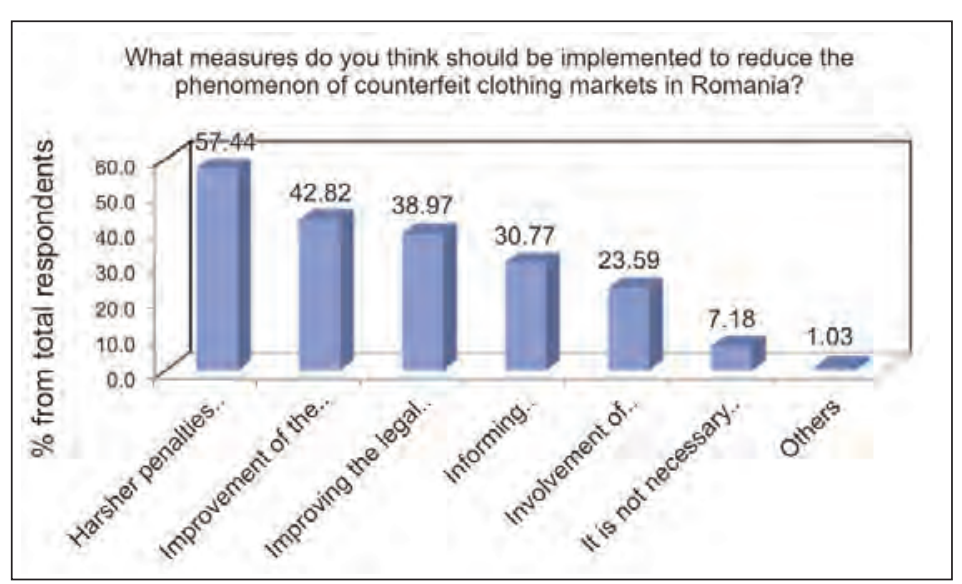

Fig. 8. Measures to reduce counterfeiting Source: authors' compilation based on the results of applied questionnaire 2017, vol. GB, nr. 5 
Do you consider that counterfeit clothing affects textile industry in Romania

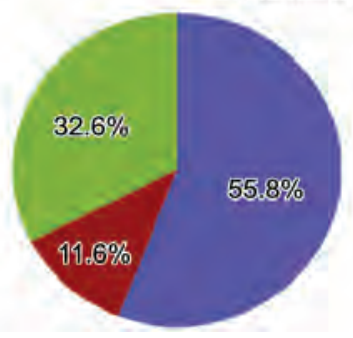

Fig. 9. Effects of the phenomenon of counterfeiting Source: authors' compilation based on the results of applied questionnaire

\section{Econometric results}

The study conducted includes an econometric analysis that was aimed at identifying the impact that certain selected variables have on the decision to buy clothes knowing that they were counterfeited. This decision was taken based on the answers given by the people questioned to the corresponding question introduced in the questionnaire. The initial variable was post-coded and a new binary variable was built which takes the value 0 if the person questioned bought clothing knowing that they were counterfeit and the value 1 if the person did not buy anything. Because the dependent variable is a binary one, the suitable model of econometric analysis in this case is the logistic regression. The logistic regression models the relationship between a series of independent variables $x_{i}$ (categorical, continuous) and a dichotomous dependent variable $Y$ (nominal, binary). Such a dependent variable typically occurs when it represents the

$$
p_{i}=\frac{1}{1+\mathrm{e}^{-\left(\beta_{0}+\sum_{j=1}^{k} \beta_{j} x_{i, j}\right)}}
$$

If a logistic transformation is applied to the equation above, the following linear relationship between logit $\left(p_{i}\right)$ and the explanatory variables is obtained:

$$
\operatorname{logit}\left(p_{i}\right)=\log \left(\frac{p_{i}}{1-p_{i}}\right)=\beta_{0}+\sum_{j=1}^{k} \beta_{j} x_{i, j}
$$

This last equation is called the logit form of the model, where logit $\left(p_{i}\right)$ is the logarithm of the likelihood of an event to be accomplished in relation to the explanatory variables.

In this study, the binary variable corresponding to the decision to buy clothes knowing that they are counterfeited, which takes the value 0 if the person buys something and the value 1 if the person does not buy anything, was considered as a dependent variable. The explanatory variables chosen were: age, residence, gender, income levels, marital status and last level of education graduated. All variables were transformed into binary variables and the software used was SPSS. Following the completion of the logistic regression estimation only two independent variables passed the tests of significance - the age and marital status. The results of the regression estimation are presented below (table 1 and 2).

The results of the logistic regression show that young people (16-24 age group) are less willing to buy counterfeited clothes compared to the age group of over 25 (coefficient 0.327 ). It is possible that this result be linked to the fact that brand is important for the young people, especially since they are a lot more informed and a counterfeit product could be

\begin{tabular}{|c|c|c|c|c|c|c|c|}
\hline \multicolumn{8}{|c|}{ VARIABLES IN THE EQUATION } \\
\hline & & B & S.E. & Wald & df & Sig. & $\operatorname{Exp}(B)$ \\
\hline \multirow{3}{*}{ Step $1^{a}$} & age & -1.118 & .358 & 9.759 & 1 & .002 & .327 \\
\hline & married & 1.100 & .418 & 6.938 & 1 & .008 & 3.005 \\
\hline & Constant & -.914 & .440 & 4.319 & 1 & .038 & .401 \\
\hline
\end{tabular}

a Variable(s) entered on step 1: age, married.

affiliation to two classes, categories etc. The regression equation obtained, of a different type from other types of regressions offers information about both the importance of variables in differentiating classes and the classification of an observation in a class.

Assuming that the $Y$ values (binary variable) are coded $0 / 1$, the 0 value generally expresses the occurrence of a certain event, so that what is being sought is an estimation of the likelihood that that certain events is produced depending on the values of the independent variables.

Basically, the logistic regression describes a nonlinear relationship between the binary variable $Y$, which takes the values 0 or 1 , and $k$ explanatory variables $x_{1}, x_{2}, \ldots, x_{k}$. The logistic model is described by the equation:

Table 2

OMNIBUS TESTS OF MODEL COEFFICIENTS

\begin{tabular}{|cl|c|c|c|}
\hline & & Chi-square & df & Sig. \\
\hline \multirow{3}{*}{ Step 1 } & Step & 56.647 & 2 & .000 \\
& Block & 56.647 & 2 & .000 \\
& Model & 56.647 & 2 & .000 \\
\hline
\end{tabular}

\begin{tabular}{|c|c|c|c|}
\hline \multicolumn{4}{|c|}{ MODEL SUMMARY } \\
\hline Step & $\begin{array}{c}-2 \text { Log } \\
\text { likelihood }\end{array}$ & $\begin{array}{c}\text { Cox \& Snell R } \\
\text { square }\end{array}$ & $\begin{array}{c}\text { Nagelkerke R } \\
\text { square }\end{array}$ \\
\hline 1 & $339.467^{a}$ & .169 & .233 \\
\hline
\end{tabular}

a Estimation terminated at iteration number 5 because parameter estimates changed by less than .001 . 
easily found in the environments they usually attend, and this would harm their "image".

On the other hand, we notice that married people are more willing to buy clothes knowing that they are counterfeited as opposed to unmarried people (coefficient 3.005). In this case, the explanation could be given by price, thus it is possible that married people put more emphasis on quality/price ratio and less on the brand.

\section{CONCLUSIONS}

The effects of counterfeiting are not to be neglected at any level. Counterfeiting affects industry and especially the producers of original goods by practicing unfair competition, whilst generating social costs. As for the end consumers, counterfeiting could signify an improperly quality/price ratio or situations of endangering the health of consumers.

The counterfeiting producers do not pay taxes to the state and usually do not comply with any legal provisions specific to the countries where they operate. In most cases, their employees work in unsafe environments and receive wages under the counter, and thus they do not benefit from a potential pension or health insurance. These are just some of the negative effects that affect both the state, which no longer has sources of revenue to invest in infrastructure, combating organized crime, health services, etc. and companies which operate legally [37]. If the producers of fakes hold a significant market share, they can turn into real barriers for the competitors that obey the law and want to enter the market [38].

Usually counterfeiting is associated to criminal activities. The Interpol reported that there are links between the producers of "fakes" and terrorist cells in the Middle East, Europe and Latin America [39]. It also shows that since the producers of fakes do not sell the latter in the same jurisdiction of the production, they are very difficult to penalize [40].

Therefore, for many companies and authorities around the world, combating counterfeiting has become vital [41]. This threat requires the use of advanced technologies dedicated to the fight against counterfeiting in order to protect both the genuine products and the companies against unfair competition. Currently, there are a number of anti-counterfeiting technologies, such as: watermarks, holograms, colour shifting ink, security thread, micro-printing, anti-fake ink, barcode technology, holographic technology etc. However, producers of fakes always find creative ways to sell their products [42].

One of the ways to reduce the phenomenon might be to use some common databases containing information about companies that produce fakes. Furthermore, companies that produce branded clothes could provide the authorities with databases of information about the details that can quickly help with the differences between the famous brands and the so-called "fakes".

Another aspect that the authorities rely on in combating the phenomenon, beyond the direct measures taken, refers to the issues of morality. The evidence of the empirical studies show that there are individuals who refrain from purchasing counterfeited products especially because that is an immoral and illegal practice that may endanger their health [43]. Moreover, it is very important to implement some efficient programs to inform and educate the general public.

As Chaudhry et all showed in their article on the retention of intellectual property rights, there should be a global action plan with several components, involving the members of the supply chain, the employees and the authorities that have the power to enforce the law and to create a culture of anti-counterfeiting [44].

In order to diminish the phenomenon, a set of measures is clearly needed - measures that should include anti-counterfeiting technologies, a consistent and enforced legislation and an unceasing and permanent education of the consumers. Basically we can say that we are at a crossroads: we either adopt a zero tolerance policy towards counterfeit products, or we risk adopting a path of indifference, which in the long run may prove disastrous.

\section{BIBLIOGRAPHY}

[1] Phillips, T. Knock off: The deadly trade in counterfeit goods. In: London: Kogan Page, 2005.

[2] Rutter, J. and Bryce, J. The consumption of counterfeit goods: 'Here be pirates?', In: Sociology no. 42; 1146, 2008, http://soc.sagepub.com/cgi/content/abstract/42/6/1146.

[3] Grocery Manufacturers Association \& A.T. Kearney. Consumer product fraud: Deterrence and detection, 2010, In: http://www.gmaonline.org/downloads/wygwam/consumerproductfraud.pdf.

[4] Lai, K.K., Zaichkowsky, J.L. Brand imitation: Do the Chinese have different views?, In: Asia Pacific Journal of Management, 16(2), 1999, pp. 179-192.

[5] Wilcock, A., Boys, K. Reduce product counterfeiting: An integrated approach, In: Business Horizons no. 57, 2014, pp. 279-288.

[6] Organization for Economic Cooperation and Development. Magnitude of counterfeiting and piracy of tangible products: An update, 2009, In: http://www.oecd.org/dataoecd/57/27/44088872.pdf.

[7] Frontier Economics Ltd. Estimating the global economic and social impacts of counterfeiting and piracy. In: London: Business Action to Stop Counterfeiting and Piracy (BASCAP), 2011.

[8] International Anti-Counterfeiting Coalition. The negative consequences of international intellectual property theft: Economic harm, threats to the public health and safety, and links to organized crime and terrorist organizations, In: (White Paper). Washington, 2005, DC: IACC.

[9] Orchard, R. The anti-counterfeiting group: A 30-year campaign against the trade in fakes. In: T. Little (Ed.), Anticounterfeiting 2010 - A global guide (pp. 22-25). London: Globe Business Publishing, 2010.

[10] Wischermann, D. Countering the counterfeiters, innovation and technology transfer: The newsletter of the innovation programme, 1999, In: http://cordis.europa.eu/itt/itten/99-5/prog2.htm. 
[11], [12] European Commission, Report on EU Customs enforcement of intellectual property rights. Results at the EU border, 2015, In: https://ec.europa.eu/taxation_customs/sites/taxation/files/2016_ipr_statistics.pdf

[13] Amariei, R. Crisis boosts counterfeit market in Romania, Capital Magazine, 2009, In: http://www.capital.ro/crizarelanseaza-piata-falsurilor-in-romania-125697.html.

[14] Berman, B. Strategies to detect and reduce counterfeiting activity. In: Business Horizons, 2008, 51(3), pp. 191-199.

[15] Protecting your brand online: The new marketing imperative, 2013, In: http://www.bizreport.com/whitepapers/ protecting_your_brand_online_the.html.

[16] Kaikati, J.G., LaGarce, R. Beware of international brand piracy. In: Harvard Business Revue 1980, 58(2):52-8.

[17] Hansen, J. The capital of counterfeiting. In: Duns Revue 1978:69 (October).

[18] Higgins, R.S., Rubin, P.H. Counterfeit goods, In: Journal Law Economics, 1986, 29(2):211-30.

[19] Grossman, G.M., Shapiro, C. Counterfeit-product trade. In: American Economic Revue, 1988, 78(1), pp. 59-75.

[20] Wilcock, A., Boys, K. Reduce product counterfeiting: An integrated approach, In: Business Horizons no. 57, 2014, pp. 279-288.

[21] Chaudhry, P.E., Chaudhry, S., Stumpf, S., Sudler, H. Piracy in cyber space: Consumer complicity, pirates, and enterprise enforcement. In: Enterprise Information Systems, 2011, 5(2), pp. 255-271.

[22] Romani, S., Gistri, G., Pace, S. When counterfeits raise the appeal of luxury brands. In: Marketing Letters, 2012, 23(3), pp. 807-824.

[23] Grossman, G.M., Shapiro, C. Counterfeit-product trade. In: American Economic Revue, 1988, 78(1), pp. 59-75.

[24] Ritson, M. Fakes can genuinely aid luxury brands. Brand Republic, 2007, In: http://www.brandrepublic.com/News/ 673098/Fakes-genuinely-aidluxury-brands/.

[25] Yoo, B., \& Lee, S.-H. Buy genuine luxury fashion products or counterfeits. In: Advances in Consumer Research, 2009, 36(1), pp. 280-228.

[26] Gistri, G., Romani, S., Pace, S., Gabrielli, V., Grappi, S. Consumption practices of counterfeit luxury goods in the Italian context. In: Journal of Brand Management, 2009, 16(5/6), pp. 364-374.

[27] Stottinger, B., Penz, E. Concurrent ownership of brands and counterfeits: Conceptualization and temporal transformation from a consumer perspective. In: Psychology and Marketing, 2015, 32(4), pp. 373-391.

[28] Commuri, S. The impact of counterfeiting on genuine-item consumers'brand relationships. In: Journal of Marketing, 2009, 73(3), pp. 86-98.

[29] Veblen, Th. Teoria clasei de lux, In: Editura Publica, 2009, Bucuresti.

[30] Truong, Y. Personal aspirations and the consumption of luxury goods. In: International Journal of Market Research, 2010, 52(5), pp. 653-673.

[31] Eisend, M., Schuchert-Güler, P. Explaining counterfeit purchase: a review and preview. In: Academy of Marketing Science Review, 2006, 12, pp. 1-26.

[32] Poddar, A., Foreman, J., Banerjee, S., Ellen, P.S. Exploring the Robin Hood effect: Moral profiteering motives for purchasing counterfeit products. In: Journal of Business Research, 2012, 65(10), pp. 1500-1506.

[33] Han, Y.J., Nunes, J.C., Drèze, X. Signaling status with luxury goods: The role of brand prominence. In: Journal of Marketing, 2010, 74(4), pp. 15-30.

[34] Cheung, W.L., Prendergast, G. Buyers' perceptions of pirated products in China, In: Marketing Intelligence \& Planning, 2006, 24(5), pp. 446-462.

[35] Gentry, J.W., Putrevu, S., Schultz, C., II, Commuri, S. How now Ralph Lauren? The separation of brand and product in a counterfeit culture. In: M. Gilly \& J. Meyers-Levy (Eds.), Advances in consumer research (Vol. 28, pp. 258-265), 2001. Valdosta, GA: Association for Consumer Research.

[36] The National Institute of Statistics, Press release nr. 135. Household income and expenditure in 2014, 2015, In: http://www.insse.ro/cms/files/statistici/comunicate/com_anuale/venituri\%20si\%20cheltuieli/ABF_2014r.pdf.

[37] Hardy, J. Flood of fakes hinders business efforts to grow economy and pinches government budgets. In: T. Little (Ed.), Anti-counterfeiting 2010 - A global guide, 2010, (pp. 14-17). London: Globe Business Publishing.

[38] Wilcock, A., Boys, K. Reduce product counterfeiting: An integrated approach, In: Business Horizons no. 57, 2014, pp. 279-288.

[39] Orchard, R. The anti-counterfeiting group: A 30-year campaign against the trade in fakes. In: T. Little (Ed.), Anticounterfeiting 2010 - A global guide (pp. 22-25). London: Globe Business Publishing, 2010.

[40] Chaudhry, P.E. Protecting your intellectual property rights. In: Business Horizons, 2013, 56(2), pp. 131-133.

[41] Chaudhry, P.E., Chaudhry, S., Stumpf, S., Sudler, H. Piracy in cyber space: Consumer complicity, pirates, and enterprise enforcement. In: Enterprise Information Systems, 2011, 5(2), pp. 255-271.

[42] Burhouse, R. How new packaging technologies are helping in the struggle against counterfeit drugs, 2010, In: http://www.pharmamanufacturing.com/articles/2010/119.html

[43] Furnham, A., Valgeirsson, H. The effect of life values and materialism on buying counterfeit products, In: The Journal of Socio-Economics, 2007, Vol. 36, No 5, pp. 677-685.

[44] Chaudhry, P.E., Zimmerman, A., Peters, J.R., Cordell, V.V. Preserving intellectual property rights: Managerial insight into the escalating counterfeit market quandary. In: Business Horizons, 2009, 52(1), pp. 57-66.

\section{Authors:}

Assistant PhD CRISTINA DIMA ${ }^{1}$

Associate professor PhD LIANA BADEA ${ }^{2}$

Associate professor PhD AMALIA CRISTESCU ${ }^{2}$

${ }^{1}$ University Politehnica of Bucharest

Splaiul Independentei nr. 313, sector 6, Bucuresti, Romania

2 Bucharest University of Economic Studies 6 Piata Romana, $1^{\text {st }}$ district, 010374 Romania e-mail: cristina.visan0187@gmail.com, liana.nutu.badea@gmail.com, cristescuamalia@gmail.com

\section{Corresponding author:}

CRISTINA DIMA

cristina.visan0187@gmail.com 


\title{
Multicriteria ranking of a job positions by ELECTRA methods in order to improve the analysis and conditions at work in companies in the textile industry
}

\author{
DOI: $10.35530 / 1 T .068 .05 .1378$
}

SNEŽANA UROŠEVIĆ

DRAGAN ĐORĐEVIĆ

DARKO RADOSAVLJEVIĆ

GORDANA KOKEZA

VIOLETA STEFANOVIĆ

\section{REZUMAT - ABSTRACT}

Clasificarea multicriterială a locurilor de muncă prin metodele ELECTRA pentru îmbunătățirea analizei și a condițiilor de lucru în cadrul companiilor din industria textilă

Aplicarea metodelor tehnologice adecvate pentru fabricarea anumitor produse are adeseori ca rezultat un impact negativ asupra angajaților din procesele respective. Nivelul impactului negativ al aplicării anumitor procese tehnologice asupra angajaților variază în funcție de industrie și de nivelul de dezvoltare tehnologică al unei companii. Pentru a identifica aceste efecte negative, este necesar să se efectueze o analiză adecvată a locurilor de muncă din industria producătoare din expunerea la anumiți factori de influență. Acest studiu prezintă rezultatele clasificării multicriteriale a șaisprezece locuri de muncă diferite din fabricile de textile care produc și prelucrează fibre în zona orașului Leskovac din Republica Serbia, pe baza a șase parametri care măsoară și definesc în mod regulat condițiile mediului de lucru. Au fost analizate condițiile mediului de lucru prin măsurarea parametrilor mediului de lucru: temperatura aerului și zona de confort în timpul iernii (microclimatul), prin determinarea prezenței surselor chimice dăunătoare și a pericolelor care apar în timpul utilizării echipamentului de lucru, a zgomotului, a prezenței vibrațiilor și a nivelului de lumină de la locul de muncă. La definirea criteriilor de dificultate la locul de muncă s-a ținut seama de faptul că toți parametrii mediului de lucru nu au aceeași importanță, și anume faptul că aceștia nu au același impact asupra sănătății angajaților. Rezultatele indică faptul că această metodă poate fi utilizată cu succes pentru a rezolva aceste probleme în alte industrii, iar datele pot fi aplicate pentru a îmbunătăți condițiile de muncă, în special la locurile de muncă care sunt cele mai expuse la efectele nocive ale mediului de lucru.

Cuvinte-cheie: condiții de lucru, loc de muncă, industria textilă, metoda ELECTRA, clasificare multicriterială

Multicriteria ranking of a job positions by ELECTRA methods in order to improve the analysis and conditions at work in companies in the textile industry

Application of appropriate technological methods of production of certain products often causes the negative impact on the employees in the respective processes. The level of the negative impact of the application of certain technological processes on employees varies depending on where the industry is doing, and depending on the level of technological development for a company. In order to identify those negative impacts, it is necessary to perform a proper analysis of manufacturing jobs from the exposure to given influences. This study presents the results of the multi criteria ranking of sixteen different workplaces in textile factories producing and processing fibre in the area of the city of Leskovac in Republic of Serbia, based on six parameters that regularly measure and define the conditions of the working environment. There were analyzed the working environment conditions by measuring the parameters of the working environment: air temperature and comfort zone in winter (microclimate), by determining the presence of harmful chemical sources and hazards that occur while using working equipment, noise, the presence of vibration and the level of light at the workplace. When defining the criteria of a job difficulty it was taken into account the fact that all the parameters of the working environment are not of the equal significance, namely they all do not have the same impact on the health of the employees. The results indicate that this method can be successfully used to solve these problems in other industries, as well as data knowledge can be applied in order to improve working conditions, especially in jobs that are most exposed to the harmful effects of the working environment.

Keywords: working conditions, workplace, textile industry; ELECTRA method, multicriteria ranking

\section{INTRODUCTION}

Health, safety and general working conditions are very important fields for researching and functioning of human resources. This is the prime concern of the personnel management. Being aware of the factors that affect the health and safety of employees, such as the attitudes of workers and accidents at work, is crucial. Because of the fact that health and safety are related to the welfare of individuals, the attitudes of employees on these issues must be taken into account when planning the program for the protection of health and safety of the staff [1]. Safety and health at work mean organizing such working conditions which, to the most possible extent, reduce injuries, occupational diseases and diseases related to work and predominantly create the state of full physical, mental and social well-being of employees, 
as determined by the regulations of Occupational Safety and Health Act Republic of Serbia [2-3]. As many parameters of the working environment represent a risk to human health, the allowed values of these parameters are defined by relevant acts and directives the Regulations of the Republic of Serbia and standards [4-5].

The last few decades have been characterized by continuous testing and development of many methods and measures in order to improve working conditions. Examination of working environment is of great importance for the safety of workers. The aim of the implementation of the regulation is implementing the appropriate measures with the aim of the better workers protection, the reduction of risks at work, defining the benefits for workers etc. Many workplaces in industry and economy are characterized by difficult working conditions. Employees at these workplaces are exposed to high or low temperature, chemical hazards, noise, vibrations etc.

Identifying the danger, assessing the risk of injuries and defining the measures for elimination or reduction of risk at work is an extremely complex and highly responsible job for those who are responsible for safety and health protection. It is urgent to define guidelines that can help organizations in the formulation of risk acceptance criteria for occupational environments [6]. According to the analyses and assessment of risks at workplace and the results obtained using the method of multi criteria decision making, the most difficult workplaces in the company, i.e. the ones with the greatest health risk, can be determined. The significance of these analyses is great as they are concerned with the improving of the working conditions, the protection of the workers' health, increasing their satisfaction and achieving better working results. Effective and powerful system of managing the health and safety of employees at work can help to transfer the uncontrolled threat to controlled risk and thus better protect the welfare of employees and companies.

Safety and health measures have a very important role in any industry. Each branch of industry has specific working conditions they are exposed to their employees, and there is a large number of jobs in a cold environment and low temperature working environment that can be hazardous to the human body, such as in the sector of food production and storage [7]. Especially those employed in textile industry are exposed to a number of potential dangers and harmful effects on health and safety, and the possibility of incidents is very big. Therefore it is very important for employees to be aware of different professional risks. At the same time, it is essential that management take the necessary measures to protect workers from potential hazardous situation. The company's management has an extremely important role in providing conditions that enable creating the staff for textile industry [8].

Employees are fully aware of the importance of health, safety and well-being, because they are important for their life and future [9]. All measures are aimed at the main goal - a more satisfied worker - a higher productivity at work. Appropriate working environment ensures the well-being of employees who will always readily carry out their roles in order to provide higher productivity [10]. It can be also concluded that the work environment affects job satisfaction and achievement of the objectives of the organization [11]. Normala in his study shows that the quality of working life of employees is an important factor for employers who are interested in improving employee satisfaction and their deduction to work [12]. Ultimate success for enterprise will be when satisfaction of workers results in increased loyalty and talent retention Indumathy and Kamalraj has remarkably pointed out that the major factors that influence and decide the Quality of Work Life are attitude, environment, opportunities, nature of job, people, stress level, career prospects, challenges, growth and development and risk involved in the work and rewards [13-14].

This study presents the results of the multi-criteria ELECTRA method used for the complete ranking of workplaces according to the difficulty of working conditions based on many multiple criteria at the same time (the parameters of the working environment). The aim of the ranking is to make the list of workplaces from the most difficult to the easiest one. The results can be useful to the company management in order to improve working conditions, maintain the health care of workers and achieve better outcomes.

\section{THE INFLUENCE OF THE WORKING ENVIRONMENT ON THE HEALTH AND SAFETY OF EMPLOYEES IN THE TEXTILE INDUSTRY}

Textile industry is very complex, based on mechanical component with the elements of chemical technology. Textile production requires several stages of machine processing, such as spinning, weaving, knitting and garment production, as well as chemical processing such as dyeing, printing, additional textile processing and final garment processing. Literally, there is not a single textile product that is not chemically treated. Textile industry emits a wide range of pollutants at all stages of converting fibers into a finished fabric [15].

The technological processes of textile industry use a number of different groups of chemicals such as different types of organic dyes, solvents, bleach, heavy metals etc. Colours can be a threat to the environment due to the presence of a large number of contaminants, such as toxic organic residues, acids, bases and inorganic matter, but they themselves represent a great danger to the health of workers due to their presence in technological processes [16]. In textile units unfavorable microclimate conditions prevail: high air temperature (over $30^{\circ} \mathrm{C}$ ) and high humidity (90\%), and often insufficient light inside. In the whole line of the textile industry production, there is a risk of injury, the most often by mechanical force, or gaining burns from heat or chemicals. All these factors are present in the process of production and processing 
of textiles and they may also affect the incidence of occupational diseases of workers, absence from work, decrease their working ability and productivity. It is for these reasons that the textile industry is defined as an increased risk sector.

Many employees in the worldwide companies of the textile industry work in unacceptable conditions [17-18] which negatively affect the health and safety of workers. It is known that there is a number of factors that threaten the man both at his workplace and outside it - physical factors: microclimate (temperature, humidity and air velocity), light, noise, vibration, and radiation and factors arising from the machines while working, equipment, use of tools and the dangerous effects of electric current, chemically and biologically active agents. All these factors are present in the process of production and processing textiles, and they may affect the incidence of occupational diseases of workers, absence from work, reduction of their working capacity and productivity. Reproductive health may be endangered if employees are exposed to chemicals, high temperature of the working environment, noise.

Workers in textile industry are exposed to a large number of chemicals, especially those engaged in dyeing, printing and the final textile processing. Various production processes use chemicals based on benzidine, organic solvents and chemicals, which are used in anti-crease finishing, emit formaldehyde, in protection against flammability use organophosphorus or organobromine compounds then, antimicrobials are also used in various textile operations. Studies have shown the relationship between exposure to formaldehyde and lung and brain cancer, as well as leukemia. Skin damage resulting from the activity of harmful agents in the working environment represents a group of the most common occupational diseases in the textile industry. Presence of professional dermatoses, caused by the activity of chemicals in relation to other occupational diseases, ranges from 20 to $70 \%$.

Workers in textile industry from developing countries are exposed to high level of noise. Exposure to noise over a long period can damage the eardrum and can cause the hearing loss. Other problems such as tiredness, absence from work, disturbance, anxiety, reduction of work capacity and efficiency, variations in heart rate and blood pressure, and sleep disorder are also observed in the continuous exposure to noise. A lack of effective maintenance of machines is one of the main reasons for the increase of noise levels in most of the textile processing units. Although noise exposure in textile processes causes serious health problems, they are often ignored because its effects are not immediately visible.

Ergonomic problems were observed in most of the work units related to the production of textiles and clothing. Employees in textile units have unsafe and unhealthy working environment because they face big problems: inadequate furniture, inadequate ventilation and light, as well as the lack of effective security measures in the case of emergency. Workers in such production units are at risk of developing a variety of occupational diseases.

With the progress of industrial production hazardous and harmful substances that may be a potential danger to the employee and his environment increase in number. Therefore, it is important that we pay special attention to these problems in both industrial microclimate conditions and the conditions of urban environment.

\section{METHODOLOGY}

The application of the ranking method will help obtaining the results and the qualitative analysis of factors and attributes that influence the whole process. There are a number of ranking methods that are used in many fields [19-22]. Multiple criteria decision making methods are successfully used to solve the problem of making decisions in situations where there are multiple criteria for the selection of raw materials, fabric and to solve problems in the textile industry. Ghosh et al. show the evaluation and selection of raw materials, or cotton fibers in the textile industry, using the Electra to be ranked feedstock [23]. The proposed approach yields good rank correlation between the quality value of the raw material and the breaking strength of final yarn. Moreover, the approach is flexible and can be modified with ease depending upon the technology of spinning being used in the industry.

Application of multiple criteria decision making show the Alam and Ghosh when evaluating the thermal comfort index fabrics taking into account four criteria for passing parameters of fabric [24]. These methods allow the determination of the quality of alternatives and criteria, as well as the level of their impact and the result of ranking.

The first step in the process of research was defining the alternatives. The next was the selection of criteria essential in making decisions. Criteria are assigned certain severities, depending on the importance of each criterion, and the number of the severities must equal 1. The method ELECTRE consists of input that contains of a decision matrix and the criteria of severity, as well as nine steps. The steps in resolving are [25-26]:

- Calculation of the standardized decision matrix;

- Calculation of the pondered standardized decision matrix;

- Determination of the set of agreements and disagreements;

- Calculation of the matrix of agreement;

- Calculation of the matrix of disagreement;

- Calculation of the matrix of domination according to agreement;

- Calculation of the matrix dominated according to disagreement;

- Calculation of the aggregate matrix of domination; - The elimination of the weakest alternatives.

The practical process of eliminating the values of less desirable actions is necessary to examine the condition of dominance for all possible pair combinations. 
Action with a greater number of elements ( $\operatorname{mad}=1$ ), dominates the others, and in a situation when the number of such elements is equal it is not possible to establish the state of domination. The same conclusion regarding the absence of domination between individual actions can be derived in the case where all of the action elements are $\operatorname{mad}=0$.

\section{THE RESULTS OF RESEARCH}

It is especially important to note that the survey was conducted in the city of Leskovac, which has a long tradition of production of textiles and textile product, textile, which is the first textile factory was built in 1884 godne then laid the foundations for Leskovac's textile industry, including the textile industry of Serbia. Due to the development of the textile industry the city formerly known as "Serbian Manchester", is trying to regain its old splendor, and is today represented in Leskovac production, from primary production of yarn of different composition to finished products (knitwear, socks, light and heavy confection).

On the basis of data obtained from several textile factories in the City of Leskovac, the work environment conditions were analyzed, obtained by measuring microclimate parameters: temperature, relative humidity, air circulation and the comfort zone in the winter, as well as the presence of harmful chemicals, noise, vibration and the level of light at the work place, which are also determined in the winter.

Testing of the working conditions was carried out in sixteen different production units in textile factories engaged in the production and processing fibre. These are specific workplaces in this company where the working conditions are the most difficult. The six parameters of the working environment which are the criteria of the workplace ranking were considered. They will get the difficulty coefficients that determine their impact on the outcome of the ranking.

Examination of working environment is done periodically during the summer when the temperature is above $15^{\circ} \mathrm{C}$, and in the winter when the temperature is below $5^{\circ} \mathrm{C}$. These periodic tests are carried out at every workplace in the working environment within three years from the date of the previous test.

The temperature, air circulation and relative humidity are the parameters of the microclimate, all examined at workplaces in the working environment of the work process, or at places where employees move or stay for more than two hours during the work time. Light is very important for working and significantly affects the quality of work [27]. Examination of physical harmfulness of noise and vibration is done at the workplace where they occur in the process of work. Noise tests and vibration tests are done by measuring, analyzing and comparing them to the standard values [28-29]. The increase of certain values significantly influences the health of workers [30].

In order to analyze the data in table 1, it was introduced the data provided on the basis of the conclusions of the authorized institutions of applicability of occupational safety and health care and the working conditions in the winter period obtained from several textile factories in the city of Leskovac, Republic of Serbia, which produce, process and make the final products from fibre.

To define the difficulty criteria, it was taken into account the fact that all the parameters of the working environment were not of the same significance, that is to say not all of them have the same effect on the safety and health of employees, which is defined in table 2.

On the basis of the procedure of application of Electra method, first an evaluation matrix is formed. In this ranking, all the criteria are of qualitative or uncertain structure that cannot be precisely determined and measured. Accordingly, a qualitative scale of five levels is formed. Table 3 shows this qualitative scale, as well as the corresponding numerical value for each qualitative evaluation.

Using a qualitative scale displayed in the range from 1 to 5 , quantified decision matrix is obtained as shown in figure 1 (Quantified decision matrix). Workplaces that have been submitted to measuring of parameters of working environment are labeled from a1 to a16, and criteria - parameters that were analyzed at the workplace are marked f1, f2, f3, f4, f5 and f6.

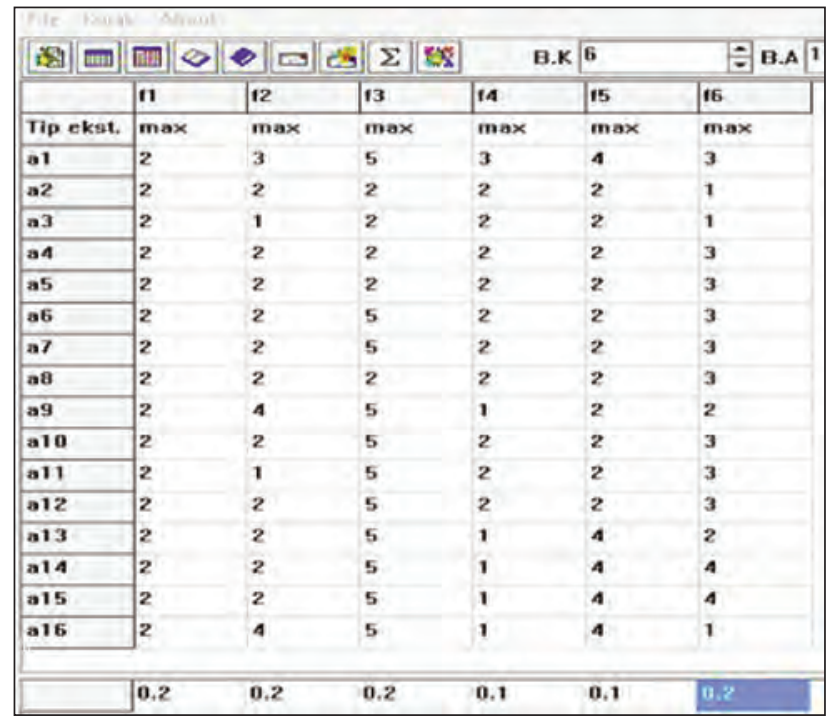

Fig. 1. Quantified decision matrix

This research proved that the textile production processes are extremely complex, mutually dependent and in most factories the production takes place in separate units, so it is necessary to consider the conditions of the working environment from unit to unit. Therefore we can say that the risk assessment of the workplace in these factories is a complex process. Parameters measure of the working environment in accordance with the acts and regulations is carried out periodically during the winter and summer. Testing the microclimate in the summer is done when the temperature is above $15^{\circ} \mathrm{C}$, and in the winter when the temperature is below $5^{\circ} \mathrm{C}$.

When ranking workplaces in this study, the data obtained by testing of working environment for the 
ANALYZED WORKPLACES AND APPLICABILITY OF OCCUPATIONAL SAFETY AND HEALTH CARE AND THE WORKING CONDITIONS IN TEXTILE FACTORIES ENGAGED IN PROCESSING AND OBTAINING THE PRODUCT FROM THE FIBER

\begin{tabular}{|c|c|c|c|c|c|c|}
\hline \multirow{2}{*}{ No } & \multirow{2}{*}{ Work place } & \multirow{2}{*}{ Micro climate } & \multicolumn{2}{|c|}{ Physical harmfulness } & \multirow{2}{*}{$\begin{array}{l}\text { Chemical } \\
\text { hazards }\end{array}$} & \multirow{2}{*}{ Light } \\
\hline & & & Noise & Vibration & & \\
\hline 1 & $\begin{array}{l}\text { Knitter in a knitting unit (smooth } \\
\text { and rough knitting unit) }\end{array}$ & acceptable level & moderate & do not exist & moderate & slight \\
\hline 2 & Rough socks production & acceptable level & $\begin{array}{l}\text { acceptable } \\
\text { level }\end{array}$ & $\begin{array}{l}\text { acceptable } \\
\text { level }\end{array}$ & $\begin{array}{l}\text { acceptable } \\
\text { level }\end{array}$ & $\begin{array}{c}\text { acceptable } \\
\text { level }\end{array}$ \\
\hline 3 & $\begin{array}{l}\text { Fine tighs production } \\
\text { (tighs sewing machine) }\end{array}$ & acceptable level & $\begin{array}{l}\text { Increased } \\
\text { risk }\end{array}$ & $\begin{array}{c}\text { acceptable } \\
\text { level }\end{array}$ & $\begin{array}{c}\text { acceptable } \\
\text { level }\end{array}$ & $\begin{array}{c}\text { acceptable } \\
\text { level }\end{array}$ \\
\hline 4 & $\begin{array}{l}\text { Tighs shaping (hand-fixing } \\
\text { of tighs) }\end{array}$ & acceptable level & $\begin{array}{c}\text { acceptable } \\
\text { level }\end{array}$ & $\begin{array}{c}\text { acceptable } \\
\text { level }\end{array}$ & $\begin{array}{c}\text { acceptable } \\
\text { level }\end{array}$ & $\begin{array}{c}\text { acceptable } \\
\text { level }\end{array}$ \\
\hline 5 & $\begin{array}{l}\text { Dye (textile dyeing tub - open } \\
\text { machine }\end{array}$ & acceptable level & $\begin{array}{c}\text { acceptable } \\
\text { level }\end{array}$ & $\begin{array}{c}\text { acceptable } \\
\text { level }\end{array}$ & $\begin{array}{c}\text { acceptable } \\
\text { level }\end{array}$ & $\begin{array}{c}\text { acceptable } \\
\text { level }\end{array}$ \\
\hline 6 & Fibre-production & acceptable level & $\begin{array}{c}\text { acceptable } \\
\text { level }\end{array}$ & do not exist & $\begin{array}{c}\text { acceptable } \\
\text { level }\end{array}$ & $\begin{array}{c}\text { acceptable } \\
\text { level }\end{array}$ \\
\hline 7 & Finishing and packaging & acceptable level & $\begin{array}{c}\text { acceptable } \\
\text { level }\end{array}$ & do not exist & $\begin{array}{c}\text { acceptable } \\
\text { level }\end{array}$ & $\begin{array}{c}\text { acceptable } \\
\text { level }\end{array}$ \\
\hline 8 & Tighs fixing-ironig & acceptable level & $\begin{array}{c}\text { acceptable } \\
\text { level }\end{array}$ & $\begin{array}{l}\text { acceptable } \\
\text { level }\end{array}$ & $\begin{array}{c}\text { acceptable } \\
\text { level }\end{array}$ & $\begin{array}{c}\text { acceptable } \\
\text { level }\end{array}$ \\
\hline 9 & $\begin{array}{l}\text { Bowe machine operator } \\
\text { (dyeing textile machine) }\end{array}$ & acceptable level & slight & do not exist & $\begin{array}{c}\text { Increased } \\
\text { risk }\end{array}$ & slight \\
\hline 10 & Thread net making & acceptable level & $\begin{array}{l}\text { acceptable } \\
\text { level }\end{array}$ & do not exist & $\begin{array}{c}\text { acceptable } \\
\text { level }\end{array}$ & $\begin{array}{c}\text { acceptable } \\
\text { level }\end{array}$ \\
\hline 11 & $\begin{array}{l}\text { Nitiworker winding rubber } \\
\text { thread }\end{array}$ & acceptable level & $\begin{array}{l}\text { Increased } \\
\text { risk }\end{array}$ & do not exist & $\begin{array}{c}\text { acceptable } \\
\text { level }\end{array}$ & $\begin{array}{c}\text { acceptable } \\
\text { level }\end{array}$ \\
\hline 12 & Dyeing-rewinding & acceptable level & $\begin{array}{c}\text { acceptable } \\
\text { level }\end{array}$ & do not exist & $\begin{array}{c}\text { acceptable } \\
\text { level }\end{array}$ & $\begin{array}{c}\text { acceptable } \\
\text { level }\end{array}$ \\
\hline 13 & The head of dyeing unit & acceptable level & $\begin{array}{c}\text { acceptable } \\
\text { level }\end{array}$ & do not exist & $\begin{array}{l}\text { Increased } \\
\text { risk }\end{array}$ & slight \\
\hline 14 & Laboratory worker & acceptable level & $\begin{array}{c}\text { acceptable } \\
\text { level }\end{array}$ & do not exist & $\begin{array}{c}\text { Increased } \\
\text { risk }\end{array}$ & slight \\
\hline 15 & $\begin{array}{l}\text { Worker at dyeing and } \\
\text { mercerising }\end{array}$ & acceptable level & $\begin{array}{c}\text { acceptable } \\
\text { level }\end{array}$ & do not exist & $\begin{array}{l}\text { Increased } \\
\text { risk }\end{array}$ & slight \\
\hline 16 & Laboratory worker & acceptable level & slight & do not exist & $\begin{array}{l}\text { Increased } \\
\text { risk }\end{array}$ & slight \\
\hline
\end{tabular}

Table 2

\begin{tabular}{|c|c|c|}
\hline \multicolumn{3}{|c|}{ THE CRITERIA DIFFICULTY COEFFICIENT } \\
\hline & $\begin{array}{c}\text { The parameters of the } \\
\text { working environment }\end{array}$ & Ponderosity \\
\hline $\mathrm{f} 1$ & Microclimate & 0.20 \\
\hline $\mathrm{f} 2$ & Noise & 0.20 \\
\hline $\mathrm{f} 3$ & Vibration & 0.10 \\
\hline $\mathrm{f} 4$ & Chemical hazards & 0.20 \\
\hline $\mathrm{f} 5$ & Light & 0.10 \\
\hline $\mathrm{f} 6$ & $\begin{array}{c}\text { Dangers that occur using } \\
\text { work equipment }\end{array}$ & 0.20 \\
\hline & $\Sigma=$ & 1.00 \\
\hline
\end{tabular}

winter period are determined by the authorized organization-Institute and are shown in table 1. By this periodic examination it was checked and determined weather the safety and health regulations at the workplace in the working environment are in accordance

\begin{tabular}{|c|c|c|c|c|}
\hline \multicolumn{5}{|c|}{ QUALITATIVE SCALE } \\
\hline $\begin{array}{c}\text { Qualitative } \\
\text { values }\end{array}$ & $\begin{array}{c}\text { Increased } \\
\text { risk }\end{array}$ & $\begin{array}{c}\text { Acceptable } \\
\text { level }\end{array}$ & Moderate & Slight \\
\hline $\begin{array}{c}\text { Numercal } \\
\text { values }\end{array}$ & 1 & 2 & 3 & 4 \\
\hline
\end{tabular}

with the regulations concerning occupational safety and health care, technical regulations and standards. To support this it should be mentioned that the technological processes in textile industry are organized in production units in which work environments are not the same, especially in terms of microclimate conditions.

This analysis, gave the list of workplaces - from the workplace with the least risk to the employee in terms of occupational safety and health to the workplace with the greatest risk to the employee considering at what extent, at that workplace in the working 
RANKING OF JOBS ACCORDING TO THE DEFINED RISK PER EMPLOYEE, FROM THE SMALLEST TO THE BIGGEST RISK

\begin{tabular}{|c|}
\hline WORKPLACE \\
\hline $\begin{array}{l}\text { knitter in a knitting unit (smooth and rough knitting } \\
\text { unit) - a1 }\end{array}$ \\
\hline $\begin{array}{l}\text { laboratory worker - a14 } \\
\text { worker at dyeing and mercerizing - a15 }\end{array}$ \\
\hline $\begin{array}{l}\text { fibre - production - a6 } \\
\text { finishing and packaging - a7 } \\
\text { bowe machine operator (dyeing textile machine) - a9 } \\
\text { thread net making - a10 dyeing-rewinding - a12 } \\
\text { laboratory worker - a16 }\end{array}$ \\
\hline $\begin{array}{l}\text { nitiworker winding rubber thread - a11 } \\
\text { the head of dyeing unit - a13 }\end{array}$ \\
\hline $\begin{array}{l}\text { shaping socks - a4 } \\
\text { dyer (textile dyeing tub - open machine) - a5 } \\
\text { ironing-fixing socks - a8 }\end{array}$ \\
\hline rough socks production - a2 \\
\hline fine tighs production (tighs sewing machine) $-\mathbf{a} 3$ \\
\hline
\end{tabular}

environment at the moment of measurement, were applied occupational safety and health protection determined by the regulations of occupational health and safety protect, technical regulations and standards. The results obtained by ranking workplaces are shown in table 4.

From the above it can be concluded that it is in the winter period, inspite of the ensured occupational safety and health protection, the workplace of the fine tighs process, is the place with the greatest risk to the employee who has an increased risk of physical harmful sources - noise and the danger that can occur using work equipment, or because of the lack of security due to the presence of rotating or moving parts, and if they are at the workplace, at the time of measurement, inspite of the fact that occupational safety and health protection is ensured.

The workplace with the smallest safety and health risk for employees is a workplace of a knitter in a knitting unit (fine and rough knitting)-a1 unit where measurements did not prove higher microclimate parameter values, noise, vibration, chemical identification, light and hazards that occur using work equipment in relation to the determined values.

The data show that workplace of a dyer-a5, is slightly lower ranked according to the stated risk compared to the production of fine tighs workplace-a3. The reason for this is the fact that occupational safety protection were ensured at this workplace-the use of protective equipment, thus the same workplace, after the measuring and ranking was not set as the place with the greatest risk to the employee, although in practice it is the workplace with the greatest risk to the employee due to the presence of dangerous chemicals, such as perchlorethylene. At the measure time it was found that the values of tested parameters were at admissible level as well that a moderate level of risk appears when using work equipment.

At the slightly lower ranking risk workplace is the workplace of shaping socks-a4 and ironing-fixing socks-a8 for which it was found, that during the measurement in winter time, the tested parameters are at permissible level value as well as that a moderate level of risk appears due to the usage of work equipment. Increased risk at this workplace occurs in summer period due to the presence of unfavorable microclimate conditions when the temperature in that unit exceeds the determined value.

\section{DISCUSSION OF RESULTS}

Based on the data obtained from several textile factories in the city of Leskovac, Republic of Serbia, which produce and process fibre, we analyzed the working environment conditions, which were obtained by measuring the parameters of the working environment: temperature and comfort zone in the winter (microclimate), determining the presence of chemical hazards and dangers that appear using work equipment, noise, vibration and level of light at the workplace.

It is known that there are numerous factors that threaten man at the workplace and outside it - physical factors: microclimate (temperature, humidity and air velocity), light, noise, vibration, and radiation and factors arising from the machine operation, equipment, use of tools and the hazardous effects of electric current, chemical and biological active agents. In the functioning of technological systems workers are exposed to different influences and actions that are the result of technological processes and operations in them. Also, since it is practically impossible to eliminate the presence of danger and harmfulness, and make stable and perfect ergonomic working tools, it is necessary to choose such a technological processing unit that gives respect to working environment conditions, the initial risk factors, includes measures, procedures and resources for timely elimination and reduction of adverse events.

Depending on the demands of the workplace and working environment impact assessment to the safety and health of employees it has been determined that there are workplaces with higher risk in the textile and clothing production process. Performed analysis made the list of workplaces - from the workplace with the smallest risk to the employee, concerning his occupational safety and health protection to the workplace with the highest risk to the employee. From the obtained results it can be determined that based on the measurement data parameters of working environment in the winter period, with ensured occupational safety and health protection in the production unit of fine thighs-a3 the place with the highest risk to the employee, with the increased risk from physical sources - noise and the dangers that can occur using working equipment, or because of the lack of security due to the presence of rotating or moving parts. 
The results obtained using this method of multiple criteria ranking show that it could be applied in determining and identifying the most difficult workplaces in textile industry, and the factory management can use it in order to improve working conditions, protection of workers' health and achieve better outcomes. On the same occasion, it may be stressed very important role of the management of human resources in health and safety protection of employees in organizations, in the textile industry, as an important field of human resource management and reducing absenteeism as a result of working conditions.

\section{CONCLUSION}

Modern business conditions imply the application of new technological solutions, both in the production process, as well as in the sphere of the entire business. However, no application najsavremnijih technology does not exclude certain negative impacts on employment that particular technology directly applicable. If so, negative impacts negatively reflected not only in the short term, employee productivity, but long-term effect on the deterioration of the health of their employees, the reduction in efficiency and thus reduce the efficiency of the undertaking and the society in general. Therefore, it is necessary to continuously monitor and improve conditions at work, in order to minimize negative effect of certain factors. Date activity positively reflected on the motivation of employees, their performance and satisfaction at work, what causes better business success, increasing its competitiveness and social responsibility. One of the modern methods of monitoring and ranking jobs is applied in this paper

This analysis, gave the list of workplaces - from the workplace with the least risk to the employee in terms of occupational safety and health protection to the workplace with the greatest risk to the employee. The results of this ranking, that was based on the data measure parameters of working environment in the winter period, with ensured occupational safety and health protection proved that the work place in the production unit of fine thighs is the work place with the greatest risk to the employee, with the increased risk from physical sources - noise and the dangers that can occur using working equipment, or because of the lack of security due to the presence of rotating or moving parts.

Identifying the danger, assessing the risk of injuries and defining the measures for elimination or reduction of risk at work is an extremely complex and highly responsible job for those who are responsible for safety and health protection. Based on the analysis and assessment of risks in the workplace and the results obtained using the method of multi-criteria decision-making may be determined to identify jobs in the organization that are most critical from the standpoint of health hazard employees. It can be concluded that the importance of the applied method of analysis large, and it is reflected primarily in the possibility of using the data obtained to improve working conditions, which contributes to maintaining the health of employees, increase their sense of security and satisfaction at work, and thus increase their motivation to achieve maximum efficiency in the conduct of their work. In this way, companies that pay adequate attention to this problem in the long term achieve greater efficiency in the use of available resources, and thus a better competitive position in the market, it said better business success.

\section{BIBLIOGRAPHY}

[1] Bogićević Milekić, B. Menadžment ljudskih resursa. In: Ekonomski fakultet. Univerzitet u Beogradu. Beograd, 2015.

[2] Official Gazette of RS, No.101/05. (SI.glasnik RS, br.101/05). Occupational Safety and Health Act Republic of Serbia.

[3] Standards BS OHSAS 18001:2007 - Management System of Occupational Health and Safety-Demand.

[4] The European Framework Directive on Safety and Health at Work (Directive 89/391 EEC and Directive 2003/10/EC.

[5] ISO 1999/90, ISO 9612/97, ISO 7726/98, ISO 7730/05, JUS U.C9.100/62 - The Regulations of the Republic of Serbia and standards.

[6] Rodrigues, M.A., Arezes, P., Leão, C.P. Risk criteria in occupational environments: critical overview and discussion, In: Procedia-Social and Behavioral Sciences. 2014, 257-262.

[7] Angelova, R. A. The effect of clothing insulation on the thermophysiological comfort of workers in artificial cold environment. In: Industria Textila, 2016, 67 (5), p. 302.

[8] Poznanović, S., Muratović Š. Significance of company management in the development of textile industry staff, In: 4rd International Conference "Economics and Management - Based on New Technologies" - EmoNT, 12-15 Jun 2014. Vrnjačka Banja: TCIP Publisher Ltd. 289-296.

[9] Torrington, D., Hall, L., Taylor, S. Menadžment ljudskih resursa. Data Status. Beograd, 2004.

[10] Akinyele, S.T. A critical assessment of environmental impact on workers productivity in Nigeria, In: Research Journal on Business Management, 2007, 1(1), pp. 50-61.

[11] Noah, Y., Steve, M. Work environment and job attitude among employees in a Nigerian work organization, In: Journal of Sustainable Society, 2012, 1(2), pp. 36-43.

[12] Normala, D. Investigating the relationship between quality of work life and organizational commitment amongst employees in Malaysian firms, In: International Journal of Business and Management. 2010; 5(10), p. 75. 
[13] Tandon, N., Reddy, E.E. Workers satisfaction in textile units in tiruppur coimbatore district. In: International Journal of Scientific \& Engineering Research, 2013, 4(8), pp. 1112 -1118.

[14] Indumathy, R., Kamalraj, S. A study on quality of work life among workers with special reference to textile industry in Tirupur district - A textile hub. In: ZENITH - International Journal of Multidisciplinary Research. 2012; 2(4), pp. 256-281.

[15] Urošević, S., Stefanović, V., Đorđević, D. Menadžment sistem zdravlja i bezbednosti na radu u tekstilnoj industriji, In: Tekstilna industrija. 2015, 62(4), pp. 39-46.

[16] Kittipichai, W., Arsa, R., Jirapongsuwan, A., Singhakant, C. Quality of life among thai workers in textile dyeing factories, In: Global journal of health science, 2014, 7(3), p. 274.

[17] Beckwith, J.R. Spinning a Yarn: The effect of labour recruitment on labour coercion in the indian textile industry, In: Politics and Society in Historical Perspective. Utrecht University, 2015.

[18] Sikhdar, M.H., Sarkar, S.K., Sadeka, S. Socio-economic conditions of the female garment workers in the capital city of Bangladesh, In: International Journal of Humanities and Social Science. 2014, 4(3), pp. 173-179.

[20] Bogdanović, D., Nikolić, Đ., llić, I. Mining method selection by integrated AHP and PROMETHEE method, In: Anais da Academia Brasileira de Ciências (Annals of the Brazilian Academy of Sciences), 2012, 84 (1), pp. $219-233$.

[21] Bogdanović, D., Miletić, S. Personnel evaluation and selection by multicriteria decision making method. In: Journal of Economic Computation and Economic Cybernetics Studies and Research. 2014; 48 (3), pp. 179-196.

[22] Bogdanović D, Stanković V, Uroševic S, Stojanović M. Multicriteria ranking of workplaces with regard to working conditions in the mining company. In: International Journal of Occupational Safety and Ergonomics (JOSE). 2016; 22 (4), pp. 479-486.

[23] Ghosh, A., Majumdar, A., Alam, S., Materials in textile spinning industry using Electre, In: Industrial Engineering Journal, 2012, V (6), pp. 6-15.

[24] Alam, M.S., Ghosh, A. Selection of cotton fabrics for optimal comfort properties using multi-criteria decision making, In: Journal of Textile and Apparel Technology and Management, 2013, 8(3), pp. 1-8.

[25] Gocić, M. Primena metode ELECTRE pri izboru laserskog štampača, YU INFO, Kopaonik, 8-12.03.2004. Zbornik apstrakta 104.

[26] Bajrami, Š. Electre i AHP-sistemi za podršku višekriterijumskom odlučivanju, In: Infoteh-Jahorina Vol. 13, 2014, pp. 599-604.

[27] Steidle, A., Werth, L. In the spotlight: Brightness increases self-awareness and reflective self regulation, In: Journal of Enviromental Psychology, 2014, 39, pp. 40-50.

[28] Thompson, M.T. Intuitive analog circuit design, Newnes, 2013, USA, pp. 617-643.

[29] Wolfgang, R., Burgess-Limerick, R. Using consumer electronic devices to estimate whole-body vibration exposure, In: Journal of Occupational and Environmental Hygiene, 2014, 11(6), pp. 77-81.

[30] Faramarzi, F., Farsangi, M.A.E., Mansouri, H. Simultaneous investigation of blast induced ground vibration and airblast effects on safety level of structures and human in surface blasting, In: International Journal of Mining Science and Technology, 2014, 24(5), pp. 663-669.

\author{
Authors: \\ Prof. $d r$. SNEŽANA UROŠEVIĆ 1 \\ Ass. prof. dr. DARKO RADOSAVLJEVIĆ 2 \\ MSC VIOLETA STEFANOVIĆ 3 \\ Prof. dr. DRAGAN ĐORĐEVIĆ ${ }^{4}$ \\ Prof. dr. GORDANA KOKEZA \\ ${ }^{1}$ Technical Faculty in Bor, University of Belgrade, \\ Vojske Jugoslavije 12, Bor, Serbia \\ ${ }^{2}$ Faculty of Technology and Metallurgy, Belgrade, University of Belgrade, \\ Karnegijeva 4, Belgrade, Serbia \\ ${ }^{3}$ City Administration for Inspection Affairs of the City of Leskovac, \\ Trg revolucije 45, Leskovac, Serbia \\ ${ }^{4}$ Faculty of Technology, Leskovac, University of Niš, \\ Bulevar Oslobođenja 124, Leskovac, Serbia
}

Corresponding author:

SNEŽANA UROŠEVIĆ

surosevic@tfbor.bg.ac.rs

snezanaur@gmail.com 


\section{Analyzing buying behavior of plus-size clothing consumers in e- commerce}

DOI: 10.35530/IT.068.05.1393

\section{REZUMAT - ABSTRACT}

\section{Analiza comportamentului de cumpărare al consumatorilor de îmbrăcăminte de mari dimensiuni în comerțul electronic}

În ultimii ani, obezitatea a devenit din ce în ce mai crescută în cadrul societății din motive diverse, cum ar fi viața din ce în ce mai stresantă, timpul îndelungat petrecut la birou și alimentația nesănătoasă. Prin urmare, numărul consumatorilor de îmbrăcăminte de mari dimensiuni a crescut rapid din cauza obezității crescute. Întreprinderile, care doresc să atragă atenția consumatorilor, își măresc și diversifică colecțiile de îmbrăcăminte de mari dimensiuni. În plus, întreprinderile profită și de comerțul electronic, care are o popularitate din ce în ce mai mare, prin comercializarea de colecții de îmbrăcăminte de mari dimensiuni pe propriile site-uri web și/sau site-uri de comerț electronic. Acest studiu iș̦i propune să analizeze comportamentul de cumpărare al consumatorilor de îmbrăcăminte de mari dimensiuni în comerțul electronic. În conformitate cu scopul studiului, s-a efectuat un sondaj de opinie pentru consumatorii de îmbrăcăminte de mari dimensiuni care cumpără produse de îmbrăcăminte prin intermediul internetului. Rezultatele de cercetare obținute au fost analizate și au fost sugerate recomandări.

Cuvinte-cheie: consumator de îmbrăcăminte de mari dimensiuni, comerț electronic, sector de îmbrăcăminte

\section{Analyzing buying behavior of plus-size clothing consumers in e-commerce}

During the recent years, obesity is increased in societies due to the reasons such as increasing stressful life, working long hours at desks and unhealthy nutrition. Therefore, number of plus-size clothing consumers is rapidly increased due to the increasing obesity. The enterprises, which want to attract plus-size consumers' attention, increase and enrich their plus-size clothing collections. Besides, the enterprises also take advantage of e-commerce, which has an increasing popularity, by selling their plus-size clothing collections via their own websites and/or e-commerce websites. This study aims to analyze the buying behavior of plus-size clothing consumers in e-commerce. In accordance with the aim of the research, a survey is conducted to plus-size consumers who buy clothing products via internet. Obtained research results are analyzed and suggestions are made.

Keywords: plus-size consumer, plus-size clothes, buying behavior, e-commerce, clothing sector

\section{INTRODUCTION}

\section{E-commerce concept and buying behavior of consumers in e-commerce}

Commerce is defined as the process flow associated with a commercial relationship or transaction, including activities such as purchasing, marketing, sales and customer support. E-commerce is this same process enabled by the use of communications and information technology [1]. It is the process of trading goods, information or services via computer networks including the internet [2]. Due to its increasing significance, there are different researches and studies in the literature about e-commerce concept. Some of them are focused on buying behavior of consumers in e-commerce.

Suki's (2013) study investigates consumer shopping behavior on the internet based on four aspects; the internet marketing environment, product characteristics, familiarity and promotional offers. 200 randomly selected respondents are participated in the survey. The results revealed that familiarity has a great influence on consumer shopping on the internet, followed by promotional offers. The internet marketing environment and product characteristics are given less emphasis by the respondents [3].

Another article studies how adoption and usage behavior of the internet and online shopping respectively influence the preference to use e-commerce to purchase different types of products. The survey is responded by 682 individuals. It is found that consumers, who have previously shopped online, display stronger preferences to buy products on the internet irrespective of the perceived level of product specific risks of online shopping [4].

Hernandez et al. (2010) analyze the perceptions which induce customers to purchase over the internet, testing the moderating effect of e-purchasing experience. They distinguish between two groups: potential e-customers who are considering making their first e-purchase and experienced e-customers, who have made at least one e-purchase and are thinking about continuing to do so. The results demonstrate that previous experience with the internet has 
significant importance for both initial and repeated purchases as it permits users to feel more confident during their interactions in the e-market. Nevertheless, its effect doesn't increase significantly once individuals acquire more e-purchasing experience. Regarding self-efficacy, the findings suggest that users who consider that they have more competence and capacity also have better perceptions about e-commerce and, as a consequence, carry out more online purchases. The effect of perceived usefulness is stronger for experienced e-customers [5].

Another paper endeavors to investigate the relationship between flow experience and internet shopping behavior to which the moderating role of consumer characteristics (trust propensity, willingness to buy and self-confidence) is concerned. Data is collected from 395 customers. The results show that flow experience is significantly and positively related to internet shopping behavior (continuance intention, purchase intention and impulsive buying). In addition, it also suggests that the relationship between flow experience and internet shopping behavior is moderated by consumer characteristics. Specifically, when the extent of a customer's trust propensity, willingness to buy and self-confidence is relatively high, the influence of flow experience on internet shopping behaviors is maximized [6].

Hou and Elliott's (2016) study compares male and female online bidders (2022 individuals who had participated in online auctions before) based on their motivations, psychographics and purchasing behavior. Their results show that females are more likely than males to be enjoyment seekers, information seekers, bargain hunters, variety seekers and impulsive buyers. Female online bidders also have a higher level of risk aversion and need for uniqueness, but exhibit a lower level of social interaction than males. The study also finds that males are more likely to purchase electronics and computers, whereas females are more likely to purchase books, clothing, jewelry and toys through online auctions [7].

The purpose of Martin and Jimenez's study (2011) is to find out if there are gender differences regarding the effect of three specific signals of quality (service quality, warranty and security and privacy policies) on e-satisfaction and e-trust and on the relation between satisfaction and trust. The survey is responded by 507 individuals. According to the results, gender doesn't have a moderating role on the satisfactiontrust link. Satisfaction with previous experiences is a key aspect in the generation of trust for both groups, which indicates that once a buyer is pleased with a web site, that should be enough to generate trust in the e-vendor and the web site, irrespective of buyer gender. The results also confirm that gender is a determinant (directly and indirectly) in the way a decision is taken. Females feel confident on the web site when they perceive that on the web site when they perceive that the company offers to protect their privacy and guarantees security in their online transactions. The findings also indicate that service quality influences trust towards the web site regardless of gender. Besides, influence of service quality on satisfaction is higher than its influence on trust [8].

\section{E-commerce in clothing sector and buying behavior of clothing consumers in e-commerce}

Due to the sensory and interactive nature of the clothing purchase process, clothing products are categorized as high-risk items and clothing shopping has been associated with high perceived risk. One key reason for this is the nature of clothing shopping. When consumers are shopping for clothing they like to physically examine the products to assess color, size, design and fabric. Also, for clothing product, fit is very important [9].

There is a vital discovery component within clothing stores. The consumers visit the clothing stores because they want to buy products (for example a shirt) which are proper to their styles. However, if they are unsure about the type of the product (shirt), they want to glance at all. In this context, inspiration is very important especially in emotional categories like fashion [10].

Compounding the difficulty in characterizing the product is the personal, often emotional nature of a clothing purchase. Clothing purchasing decisions are closely linked to individuals' feelings about themselves, their body image and the image they wish to project. However brand names help consumers infer certain aspects of quality or fit, especially for consumers making repeat or replenishment purchases [11].

Basic clothing products are selling well online. Because the touch and feel of basic garments are quite familiar and are fairly similar across brands, which makes the buyer less hesitant to purchase them and produces fewer surprises when the garment arrives. Also for more basic items, the fit of the different garment styles tends to be better understood, making it easier to purchase online. It can be said that more fashionable items may be more risky to purchase online [11].

However, highly innovative people, who tend to have higher incomes, higher levels of education, greater risk propensity and higher occupational status are more likely to adopt new products and services than people with low general innovativeness. Therefore, an innovative person might adopt and utilize the internet for clothing shopping even though high risk is associated with purchasing clothing on the internet [9]. As it can be seen, online clothing buying decisions are affected by lots of factors. Therefore some research results about buying behavior of clothing consumers in e-commerce are given below.

A sample of 263 men and 303 women students completed a survey that measured their online and offline clothing buying behavior, attitudes and predispositions. The results showed that, online buyers didn't differ from non-buyers in their belief in how cheap buying online is, in their overall enjoyment of shopping or in how often they bought clothing by any means. The demographic variables of age, sex and race were unrelated to online clothing buying. A 
further analysis showed that the online buyers used the internet more hours per week were more likely to buy online in the future than non-buyers [12].

Another paper aims to propose and test a model of apparel online buying behavior which is capable of explaining and predicting consumers' behavioral intention. According to the obtained results, perceived benefits and perceived risks are the main predictors of consumers' attitude towards buying apparel online. Perceived risks when buying online have a strong direct negative effect on consumers' attitude towards buying online apparel. However, an even stronger influence on consumers' attitude towards buying online apparel is given by perceived benefits. The best predictor of consumers' intention to use the internet in the online buying process is given by consumers' attitude towards buying apparel online. E-word-of-Mouth has a significant direct effect on consumers' intention to buy apparel online. Consumers rely on e-word-of-mouth when buying online, but their attitude towards buying apparel online has an obviously greater effect on their stated behavioral intention [13].

The purpose of another study was to examine selected demographic and psychological characteristics that lead consumers to buy clothing online. It surveyed 805 consumers who described their online clothing buying as well as how innovative and involved they were for clothing and fashion, how innovative they were with regard to buying on the internet and how much they purchased clothing through catalogues. Although all these variables were positively correlated with amount of online clothing purchase, a multiple regression analysis showed that being an adventurous online buyer and a heavy catalog shopper had the most impact on online clothing buying. These findings imply that online apparel buying is motivated more by internet innovativeness than by clothing innovativeness [14]. In another study, an online survey is responded by 524 individuals. The study examined the antecedents influencing customer satisfaction and repurchase intention for online clothing brands from the viewpoint of expectation-disconfirmation theory. An extended model is developed to explain repurchase intention, taking into consideration disconfirmed quality expectation as well as the concept of corporate social responsibility. The results show that offline features (service quality and product quality) have a significant effect on satisfaction while online features (information quality and system quality) have only limited effects. Satisfaction and corporate social responsibility both exert a significant effect on repurchase intention [15].

On the other hand, the difficulty of translating the instore experience to the online environment is one of the main reasons why the fashion industry has been slower than other sectors to adopt e-commerce. However, recently, new information technologies have enabled consumers to evaluate fashion online, creating an interactive and exciting shopping experience. The results from a quantitative survey of 439 consumers, suggest the need to redefine the in-store shopping experience, promoting the use of technology as a way to create an engaging and integrated experience among channels. Retailers must think in all channels holistically, boosting interactive and new technologies for the internet and taking advantage of all touch points with the consumer, including mobile devices and social networks [16].

\section{The properties of plus-size clothing consumers} and plus-size clothing market

World Health Organization defines obesity as abnormal or excessive fat accumulation, which presents a risk to health. Approximately $15-20 \%$ of adult men's body weight consists of adipose tissue whereas this ratio is between $25-30 \%$ in adult women. If these ratios exceed $25 \%$ in men and $30 \%$ in women, the term obesity is used. World Health Organization's obesity classification is used in orders to determine obesity and generally body mass index is taken into consideration. Body mass index is a value which is obtained by dividing an individual's weight $(\mathrm{kg})$ into the square of height $\left(\mathrm{m}^{2}\right)$. If the body mass index is above 30, the individual is accepted as obese [17]. In recent years the researchers dwell on the location and distribution of adipose tissue within the body instead of total fat amount. The local adipose tissue distribution differs genetically in terms of women and men. The adipose tissues are located in the upper sides of body such as waist, abdomen and chest at man type obesity. However, the adipose tissues are located in the lower sides of body such as hip, thigh and legs at woman type obesity. Waist circumference/hip circumference ratio is one of the most simple and commonly used methods which reflects abdominal fat amount. According to World Health Organization, if the waist circumference/hip circumference ratio is above 0.85 in women and 1 in men, it is accepted as man type obesity. Waist circumference measurement is also used as a practical marker. If the waist circumference is above $88 \mathrm{~cm}$ in women and $102 \mathrm{~cm}$ in men, they are accepted equal to body mass indexes which are equal or above 30 . In other words the individuals, whose waist circumferences are equal or above these values, are accepted as obese [17].

The obesity ratios are increased in societies due to sedentary life style and unhealthy nutrition. Therefore, serious issues are occurred in terms of healthy society. However, a new market segment is comprised for enterprises in order to provide clothing products needed by obese people easily, rapidly and with wide alternatives.

Size 44 and above are accepted as plus-size for women whereas as size 56 and above for men. 44/46 size is defined as large size for women at the size definitions which are done according to ISO 3635+ 3637 and waist circumference is given as $88 \mathrm{~cm}$ (initial obesity limit according to World Health Organization). The waist circumference is given as $102 \mathrm{~cm}$ (initial obesity limit according to World Health Organization) for size 56 in men [18]. 
Clothing enterprises, which see the potential of plussize market, gain places in the market by producing plus-size collections. According to an accomplished research, there are five conditions in order to be successful at plus-size clothing market. These conditions can be summarized as; preparing trendy collections, being easily accessible, creating collections which have rich contents, making sales at accessible prices and making sales via internet as well as physical stores [19].

E-commerce, which is seen as a condition of being successful at plus-size clothing market, is generally actualized via two different channels. In the first alternative, plus-size clothing products are sold as a part of different campaigns in e-commerce websites. One or more than one brands' plus-size clothing products are sold at these campaigns. These e-commerce websites can be oriented towards selling plus-size clothing products with normal size products as well as being plus-size product oriented. In the second alternative, clothing brands sell their plus-size clothing products via their own websites. Some of the clothing brands only produce and sell plus-size clothing products whereas most of them produce and sell plus-size products and normal size products together. There are different researches and studies in the literature about measurement standardization of plussize clothing consumers, design and fit of plus-size products and problems of plus-size clothing products [20-26]. However, the focus point of these studies is generally women [21-26]. There are a few studies which include men [20]. Besides there are a few studies which analyze the buying behavior of plus-size clothing consumers in e-commerce [26].

\section{THE PURPOSE AND THE METHOD OF THE RESEARCH}

The clothing enterprises give great importance to modern marketing methods in order to protect their competitiveness. E-commerce, which possesses a significant place within modern marketing methods, is frequently utilized by clothing enterprises. Plussize consumers are one of the consumer categories which attract attention of clothing enterprises. The increasing obesity ratios due to unhealthy nutrition and stressful life, head the enterprises towards producing qualified and fashionable collections for plussize consumers. These collections are offered and sold in clothing enterprises' websites or independent e-commerce websites besides their physical stores. Therefore, the study aims to analyze the buying behavior of plus-size clothing consumers in e-commerce.

In accordance with the aim of the research, a questionnaire form consisting of 29 questions is prepared. The survey is conducted within June-December 2015 at the hinterland of İzmir province by using face to face interview method. The participants of the research are plus-size Turkish residents (size 44 and above for women whereas size 56 for men), who buy clothing products via internet.
İzmir province population is 4.113 .072 according to the Turkish Statistical Institute's address based population registration system results in 2014 [27]. According to Turkish Nutrition and Health Investigation report of Republic of Turkey Ministry of Health, the obesity ratio of Aegean Region, which includes İzmir province, is $28 \%$ [28]. Accordingly, universe size is calculated as 1.151 .660 . Therefore, sample size is calculated as 267 at $95 \%$ confidence interval with $6 \%$ error margin. The consumers which would constitute the sample are determined according to snowball sampling.

After the repatriation and evaluation of the sent-back questionnaires, 304 of them are incorporated to the research. After the conduction of the survey, collected data are evaluated with SPSS program. At the beginning of statistical analysis, the reliability of the questionnaire is measured and the reliability coefficient $\alpha$ is found as 0.809 . According to this finding, the scale of the questionnaire is addressed to be highly reliable.

\section{GENERAL FINDINGS OF THE RESEARCH}

The questions which aim to specify the demographic properties of the participants are evaluated firstly. Accordingly $72 \%$ of the participants are women and the remaining $28 \%$ is men. Approximately $18 \%$ of the participants are at the age of between 18 and 22, $18 \%$ is at the age of between 23 and $27,20 \%$ is at the age of between 28 and $32,22 \%$ is at the age of between 33 and 40 and $22 \%$ is at the age of 41 and over. About $17 \%$ of the participants have 350 Euro and less monthly income whereas $25 \%$ has an income between 351 and 650 Euro, 34\% has an income between 651 and 950 Euro, 19\% has an income between 951 and 1525 Euro and 5\% has an income 1526 Euro and over. 2\% of the participants indicate their educational background as primary school graduate whereas $6 \%$ indicates as secondary school graduate, $28 \%$ indicates as high school graduate, $57 \%$ indicates as university graduate (associate degree or bachelor degree) and $7 \%$ indicates as postgraduate (master degree or PhD degree).

When the distribution of women participants according to upper body sizes are analyzed, it can be seen that $39 \%$ of them wear size 44 whereas $36 \%$ wears size $46,17 \%$ wears size $48,5,5 \%$ wears size 50 , $2 \%$ wears size 52 and $0,5 \%$ wears size 54 . Approximately $33 \%$ of the women participants wear size 44 for lower body whereas $32 \%$ wears size 46 , $22 \%$ wears size $48,9,5 \%$ wears size $50,2 \%$ wears size $52,0,5 \%$ wears size 54 and $1 \%$ wears size 56 and above. When the distribution of men participants according to upper body sizes are analyzed, it can be seen that $39 \%$ of them wear size 56 whereas $34 \%$ wears size $58,20 \%$ wears size $60,6 \%$ wears size 62 and $1 \%$ wears size 64 . About $43 \%$ of the men participants wear size 56 for lower body whereas $31 \%$ wears size $58,23 \%$ wears size $60,2 \%$ wears size 62 and $1 \%$ wears size 64 . 
Approximately $25 \%$ of the participants have been buying plus-size clothes via internet for less than 6 months whereas $34 \%$ has been buying for six months to one year, $28 \%$ has been buying for one to three years, $8 \%$ has been buying for three to five years and $5 \%$ has been buying for more than five years. About 23\% of the participants haven't bought plus-size clothes via internet within the last three months. $66 \%$ has bought one to five times whereas $10 \%$ has bought six to ten times and $1 \%$ has bought more than ten times. Approximately $23 \%$ of the participants haven't bought any plus-size clothes via internet within the last three months. $62 \%$ has bought one to five plus-size clothes whereas $13 \%$ has bought six to ten pieces and $2 \%$ has bought more than ten pieces. About $36 \%$ of the participants have spent approximately 35 Euro or less for plus-size clothes via internet within the last three months. $27 \%$ has spent between 35 and 65 Euro whereas 23\% has spent between 66 and 95 Euro, $7 \%$ has spent between 96 and 125 Euro, 5\% has spent between 126 and 153 Euro and 2\% has spent more than 154 Euro.

The participants are asked to write the e-commerce websites which they shop most frequently. According to this, Trendyol is the most used e-commerce website with $15 \%$. This website is followed by Markafoni, N11, LCW, Faik Sönmez, Morhipo, Tozlu and other websites respectively. Trendyol, Markafoni, N11, Morhipo and Tozlu are the e-commerce websites which sell products of different clothing brands. However, LCW and Faik Sönmez are Turkish clothing brands which sell their plus-size clothes via their own e-commerce websites.

The survey offers 18 statements which analyze the buying behavior of plus-size clothing consumers in ecommerce. The participants are required to choose their agreement levels for each of these statements. In quinary likert scale I absolutely agree is coded as 5 , I agree is coded as 4 , I have no idea is coded as 3 , I don't agree is coded as 2 and I don't agree absolutely is coded as 1 . The statements are sorted in descending order, based on the participants' average agreement levels. The findings are given in table 1. Table 1 indicates the participants' average agreement levels whereas figure 1 specifies the percentages of participants who choose to agree with statements. The statement numbers within the figure 1 refer to the numbers in table 1.

Table 1

\begin{tabular}{|c|c|c|c|c|}
\hline $\begin{array}{c}\text { Statement } \\
\text { numbers }\end{array}$ & Statements & $\mathbf{N}$ & Mean & $\begin{array}{l}\text { Standard } \\
\text { deviation }\end{array}$ \\
\hline 1 & I prefer to buy plus-size clothes which conceal my weight. & 304 & 4,2467 & 1,05069 \\
\hline 2 & I cannot easily find fashionable plus-size clothes. & 304 & 4,0757 & 1,02326 \\
\hline 3 & I cannot easily find affordable plus-size clothes. & 304 & 4,0592 & 1,08231 \\
\hline 4 & I cannot easily find plus-size clothes which are proper to my body shape. & 304 & 4,0559 & 1,04051 \\
\hline 5 & I cannot easily find plus-size clothes which are proper to my favorite colors. & 304 & 4,0099 & 1,02602 \\
\hline 6 & $\begin{array}{l}\text { I cannot easily find plus-size clothes which are proper to my dressing style } \\
\text { (sportive, classic etc.) }\end{array}$ & 304 & 4,0066 & 1,06239 \\
\hline 7 & $\begin{array}{l}\text { My decision for purchase is affected positively by plus-size models who } \\
\text { exhibit clothes on the websites. }\end{array}$ & 304 & 3,9605 & 1,02691 \\
\hline 8 & $\begin{array}{l}\text { I cannot easily find plus-size clothes which are proper to my preferred } \\
\text { fabric type (cotton, lycra etc.) and pattern (plain, striped, checkered etc.). }\end{array}$ & 304 & 3,9046 & 0,97533 \\
\hline 9 & I usually remodeled my purchased plus-size clothes. & 304 & 3,7336 & 1,16808 \\
\hline 10 & $\begin{array}{l}\text { My decision for purchase is affected positively by size tables on the } \\
\text { websites. }\end{array}$ & 304 & 3,7072 & 0,97653 \\
\hline 11 & $\begin{array}{l}\text { There is enough introductive information about plus-size clothes on the } \\
\text { websites. }\end{array}$ & 304 & 3,2467 & 1,14104 \\
\hline 12 & I prefer shopping via internet because I feel out of place in physical stores. & 304 & 2,6217 & 1,17664 \\
\hline 13 & I usually buy my plus-size clothes via internet. & 304 & 2,5526 & 1,09779 \\
\hline 14 & $\begin{array}{l}\text { There are enough brands and websites which sell plus-size clothes via } \\
\text { internet. }\end{array}$ & 304 & 2,4967 & 0,93342 \\
\hline 15 & $\begin{array}{l}\text { The brands and websites, which sell plus-size clothes via internet, are } \\
\text { well-recognized. }\end{array}$ & 304 & 2,4211 & 0,93007 \\
\hline 16 & I prefer shopping via internet due to the unkind behavior of sales personnel. & 304 & 2,4013 & 1,02613 \\
\hline 17 & I prefer shopping via internet due to the narrow cabins of physical stores. & 304 & 2,3882 & 1,07813 \\
\hline 18 & $\begin{array}{l}\text { The discount campaigns of brands and websites, which sell plus-size } \\
\text { clothes via internet, are adequate. }\end{array}$ & 304 & 2,2895 & 0,89466 \\
\hline
\end{tabular}




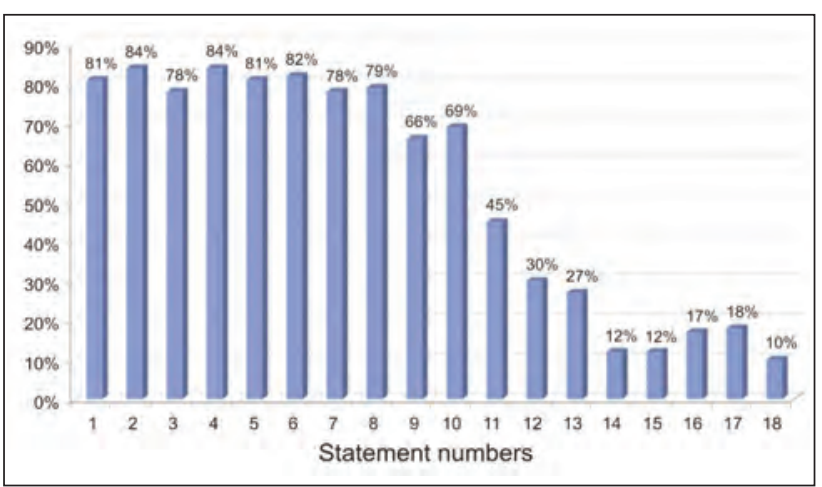

Fig. 1. Percentages of participants who choose to agree with statements

\section{MULTIPLE COMPARISON TESTS}

The hypotheses of the research are given below. The hypotheses are tested at 95\% confidence interval.

$\mathrm{H}_{1}$ : There is a statistically significant difference between participating women and men in aspect of remodeling their purchased plus-size clothes.

$\mathrm{H}_{2}$ : There is a statistically significant difference between participating women and men in aspect of preferring to buy plus-size clothes which conceal their weight.

$\mathrm{H}_{3}$ : The opinions of the participants within different income groups differ significantly about being able to find fashionable plus-size clothes.

$\mathrm{H}_{4}$ : The opinions of the participants within different income groups differ significantly about being able to find affordable plus-size clothes.

$\mathrm{H}_{5}$ : The opinions of the participants within different education levels differ significantly about being able to find plus-size clothes which are proper to their dressing styles.
$\mathrm{H}_{6}$ : The participants within different education levels differ significantly in aspect of preferring to buy plus-size clothes which conceal their weight.

$\mathrm{H}_{7}$ : The opinions of the participants within different education levels differ significantly about being able to find affordable plus-size clothes.

There is a statistically significant difference between participating women and men in aspect of remodeling their purchased plus-size clothes (Hypothesis 1) (table 2). When compared to men, more women indicate that they remodeled their purchased plus-size clothes.

There is a statistically significant difference between participating women and men in aspect of preferring to buy plus-size clothes which conceal their weight (Hypothesis 2) (table 3). When compared to men, more women prefer to buy plus-size clothes which conceal their weight.

The opinions of the participants within different income groups differ significantly about being able to find fashionable plus-size clothes (Hypothesis 3) (table 4). "I cannot easily find fashionable plus-size clothes" is indicated mostly by the income group 350 Euro and less. This group is respectively followed by the income groups 951-1525 Euro, 351-650 Euro, 651-950 Euro and 1526 Euro and over.

The opinions of the participants within different income groups differ significantly (at 95\% confidence interval) about being able to find affordable plus-size clothes (Hypothesis 4) (table 5). "I cannot easily find affordable plus-size clothes" is indicated mostly by the income group between 651 and 950 Euro. This group is respectively followed by the income groups 351-650 Euro, 350 Euro and less, 951-1525 Euro and 1526 Euro and over.

\begin{tabular}{|l|c|c|c|c|c|c|}
\hline & $\mathbf{N}$ & Mean & Std. deviation & $\mathbf{t}$ & df & Sig. (2-tailed) \\
\cline { 1 - 4 } Women & 219 & 3,8311 & 1,17846 & \multirow{2}{*}{2,353} & \multirow{2}{*}{302} & 0,019 \\
\hline Men & 85 & 3,4824 & 1,10854 & & \multirow{2}{*}{. } \\
\hline
\end{tabular}

\begin{tabular}{|l|c|c|c|c|c|c|}
\hline & N & Mean & Std. deviation & t & df & Sig. (2-tailed) \\
\cline { 1 - 4 } Women & 219 & 4,4247 & 0,93727 & \multirow{2}{*}{4,438} & \multirow{2}{*}{126,776} & 0,000 \\
\hline Men & 85 & 3,7882 & 1,18617 & & \multirow{2}{*}{. } \\
\hline
\end{tabular}

\begin{tabular}{|c|c|c|c|c|c|c|c|}
\hline & $\mathbf{N}$ & Mean & Std. deviation & $\mathbf{F}$ & $\mathrm{df}_{1}$ & $\mathrm{df}_{2}$ & Sig. \\
\hline 0-350 Euro & 52 & 4,3654 & 0,86385 & \multirow{5}{*}{3,153} & \multirow{5}{*}{4} & \multirow{5}{*}{296} & \multirow{5}{*}{0,015} \\
\hline 351-650 Euro & 76 & 4,0789 & 1,06787 & & & & \\
\hline 651-950 Euro & 100 & 4,0400 & 0,94195 & & & & \\
\hline 951-1525 Euro & 58 & 4,1034 & 1,10326 & & & & \\
\hline 1526 Euro and over & 15 & 3,3333 & 1,17514 & & & & \\
\hline
\end{tabular}




\begin{tabular}{|c|c|c|c|c|c|c|c|}
\hline & $\mathbf{N}$ & Mean & Std. deviation & $\mathbf{F}$ & $\mathrm{df}_{1}$ & $\mathrm{df}_{2}$ & Sig. \\
\hline 0-350 Euro & 52 & 4,0385 & 1,10190 & \multirow{5}{*}{4,527} & \multirow{5}{*}{4} & \multirow{5}{*}{296} & \multirow{5}{*}{0,001} \\
\hline 351-650 Euro & 76 & 4,1053 & 0,94628 & & & & \\
\hline 651-950 Euro & 100 & 4,2700 & 0,95193 & & & & \\
\hline 951-1525 Euro & 58 & 3,9483 & 1,23434 & & & & \\
\hline 1526 Euro and over & 15 & 3,0667 & 1,27988 & & & & \\
\hline
\end{tabular}

Table 6

\begin{tabular}{|c|c|c|c|c|c|c|c|}
\hline & $\mathbf{N}$ & Mean & Std. deviation & $\mathbf{F}$ & $\mathrm{df}_{1}$ & $\mathrm{df}_{2}$ & Sig. \\
\hline Primary school graduate & 6 & 4,3333 & 1,21106 & \multirow{5}{*}{2,519} & \multirow{5}{*}{4} & \multirow{5}{*}{299} & \multirow{5}{*}{0,041} \\
\hline Secondary school graduate & 18 & 4,4444 & 0,51131 & & & & \\
\hline High school graduate & 86 & 4,0930 & 0,92835 & & & & \\
\hline University graduate & 174 & 3,9713 & 1,10400 & & & & \\
\hline Postgraduate & 20 & 3,4500 & 1,35627 & & & & \\
\hline
\end{tabular}

Table 7

\begin{tabular}{|c|c|c|c|c|c|c|c|}
\hline & $\mathbf{N}$ & Mean & Std. deviation & $\mathbf{F}$ & $\mathrm{df}_{1}$ & $\mathrm{df}_{2}$ & Sig. \\
\hline Primary school graduate & 6 & 4,6667 & 0,51640 & \multirow{5}{*}{3,525} & \multirow{5}{*}{4} & \multirow{5}{*}{299} & \multirow{5}{*}{0,008} \\
\hline Secondary school graduate & 18 & 4,6667 & 0,68599 & & & & \\
\hline High school graduate & 86 & 4,3953 & 0,92392 & & & & \\
\hline University graduate & 174 & 4,1897 & 1,10893 & & & & \\
\hline Postgraduate & 20 & 3,6000 & 1,14248 & & & & \\
\hline
\end{tabular}

Table 8

\begin{tabular}{|c|c|c|c|c|c|c|c|}
\hline & $\mathbf{N}$ & Mean & Std. deviation & $\mathbf{F}$ & $\mathrm{df}_{1}$ & $\mathrm{df}_{2}$ & Sig. \\
\hline Primary school graduate & 6 & 4,5000 & 0,54772 & \multirow{5}{*}{2,466} & \multirow{5}{*}{4} & \multirow{5}{*}{299} & \multirow{5}{*}{0,045} \\
\hline Secondary school graduate & 18 & 4,0556 & 1,05564 & & & & \\
\hline High school graduate & 86 & 4,2326 & 1,03667 & & & & \\
\hline University graduate & 174 & 4,0287 & 1,09348 & & & & \\
\hline Postgraduate & 20 & 3,4500 & 1,14593 & & & & \\
\hline
\end{tabular}

The opinions of the participants within different education levels differ significantly about being able to find plus-size clothes which are proper to their dressing styles (Hypothesis 5) (table 6). "I cannot easily find plus-size clothes which are proper to my dressing style" is indicated mostly by the secondary school graduates. This group is respectively followed by primary school graduates, high school graduates, university graduates and postgraduates. As the participant education level increases, the possibility of finding plus-size clothes, which are proper to dressing styles, is increased.

The participants within different education levels differ significantly in aspect of preferring to buy plussize clothes which conceal their weight (Hypothesis 6) (table 7). "I prefer to buy plus-size clothes which conceal my weight" is indicated mostly by the primary and secondary school graduates. These groups are respectively followed by high school graduates, university graduates and postgraduates. As the participant education level increases, the possibility of buying plus-size clothes, which conceal weight, is increased.

The opinions of the participants within different education levels differ significantly about being able to find affordable plus-size clothes (Hypothesis 7) (table 8). "I cannot easily find affordable plus-size clothes" is indicated mostly by the primary school graduates. This group is respectively followed by high school graduates, secondary school graduates, university graduates and postgraduates.

\section{DISCUSSION, GENERAL EVALUATION AND CONCLUSIONS}

During the recent years, obesity is increased in societies due to the increasing stressful life, working long hours at desks and unhealthy nutrition. Therefore, number of plus-size clothing consumers is rapidly 
increased due to the increasing obesity. For this reason the growing plus-size clothing market has attracted clothing producers' attention. The enterprises, which want to attract plus-size consumers' attention, increase and enrich their plus-size clothing collections. Besides, number of physical stores, which sell plus-size clothing products, is rapidly increased during the recent years. In addition to these, the enterprises also take advantage of e-commerce, which has an increasing popularity, by selling their plus-size clothing collections via their own websites and/or e-commerce websites.

According to the results of our research, $59 \%$ of the participants have been buying plus-size clothes via internet for a year. $66 \%$ of the participants have bought plus-size clothes via internet one to five times within the last three months. $63 \%$ of the participants have spent approximately 65 Euro or less for plussize clothes via internet within the last three months. Most of the participants prefer e-commerce websites, which sell plus-size products of different clothing brands, for shopping. The enterprises, which sell plus-size clothes via their own websites, are the second choice in consumers' eyes.

As it can be seen from our research results, plus-size clothing consumers, especially women, prefer to buy plus-size clothes which conceal their weight. Besides, they demand fashionable plus-size clothes which are proper to their body shapes. Both women and men consumers indicate that they cannot easily find fashionable plus-size clothes which are proper to their body shapes. Besides, they cannot easily find plus-size clothes which are proper to their dressing styles and favorite colors and preferred fabric types and patterns. Most of the consumers, especially women, specify that they usually remodeled their purchased plus-size clothes. It can be said that, the consumers cannot easily find their desired clothes due to design and pattern mistakes. In this context, the production of fashionable but weight concealing clothes will attract consumers' attention.
According to another result of our research, most of the plus-size consumers cannot easily find affordable plus-size clothes and they indicate that the discount campaigns of brands and websites, which sell plussize clothes via internet, are adequate. If the enterprises want to attract plus-size clothing consumers' attention, they should organize more campaigns.

The results of our research also indicate that, most of the plus-size clothing consumers prefer to see size tables and plus-size models while they are buying clothes via internet. The consumers specify that both factors ease their buying decisions. On the other hand, half of the consumers indicate that there is not enough introductive information about plus-size clothes on the e-commerce websites. In this context, the enterprises, which sell plus-size clothes via internet, should give the necessary importance to these factors.

According to plus-size clothing consumers, numbers and recognition levels of brands and websites, which sell plus-size clothes via internet, are low. Most of the consumers prefer to buy their clothes from physical stores. Most of the consumers indicate that they can easily visit the stores and try on clothes in the cabins. Also most of them specify that they do not meet with unkind behavior of sales personnel. At this point, consumers' desire about buying clothes by feeling and trying come into prominence. Therefore, the enterprises, which sell plus-size clothing products via internet, should give necessary importance to advertisements and promotion activities. Besides, they should give adequate introductive information about plus-size clothes on their websites.

To sum up, the enterprises, which want to have a market share from plus-size clothing market, should design and produce fashionable and weight concealing plus-size clothes which do not differ from normal clothes in terms of design, pattern and color. Besides, they should promote their websites, frequently organize campaigns and give adequate introductive information about products on their websites in order to be successful in e-commerce.

\section{BIBLIOGRAPHY}

[1] Sproule, S., Archer, N. A buyer behavior framework for the development and design of software agents in e-commerce, In: Internet Research: Electronic Networking Applications and Policy, 2000, vol. 10, issue 5, pp. 396-405.

[2] Silveira, G.J.C. Towards a framework for operations management in e-commerce, In: International Journal of Operations \& Production Management, 2003, vol. 23, issue 2, pp. 200-212.

[3] Suki, N.M. Consumer shopping behavior on the internet: insights from Malaysia, In: Electronic Commerce Research, 2013, vol. 13, pp. 477-491.

[4] Soopramanien, D.G.R., Fildes, R., Robertson, A. Consumer decision making, e-commerce and perceived risks, In: Applied Economics, 2007, vol. 39, pp. 2159-2166.

[5] Hernandez, B., Jimenez, J., Martin, M.J. Customer behavior in electronic commerce: the moderating effect of e-purchasing experience, In: Journal of Business Research, 2010, vol. 63, pp. 964-971.

[6] Hsu, C.L., Chang, K.C., Chen, M.C. Flow experience and internet shopping behavior: investigating the moderating effect of consumer characteristics, In: Systems Research and Behavioral Science, 2012, vol. 29, pp. 317-332.

[7] Hou, J., Elliott, K. Gender differences in online auctions, In: Electronic Commerce Research and Applications, 2016, vol. 17, pp. 123-133.

[8] Martin, S.S., Jimenez, N.H. Online buying perceptions in Spain: can gender make a difference?, In: Electronic Markets, 2011, vol. 21, pp. 267-281. 
[9] Ha, Y., Stoel, L. Internet apparel shopping behaviors: the influence of general innovativeness, In: International Journal of Retail \& Distribution Management, 2004, vol. 32, issue 8, pp. 377-385.

[10] Wenig, D. How e-Bay converts digital retail?, In: Capital, 2014, vol. 9, pp. 172-176.

[11] Hammond, J., Kohler, K. E-commerce in Textile and Apparel Industries, 2000, http://projects.iq.harvard.edu/ files/hctar/files/ec01.pdf (Date of Access: May 2015).

[12] Goldsmith, R.E., Goldsmith, E.B. Buying apparel over the internet, In: Journal of Product \& Brand Management, 2002, vol. 11, issue 2, pp. 89-102.

[13] Orzan, G., Orzan, M., Iconaru, C., Macovei, O.I., Popescu, I.C. PLS based SEM analysis of apparel online behavior: the importance of eWOM, In: Industria Textila, 2003, vol. 64, issue 6, pp. 362-367.

[14] Goldsmith, R.E., Flynn, L.R., Psychological and behavioral drivers of online clothing purchase, In: Journal of Fashion Marketing and Management: An International Journal, 2004, vol. 8, issue 1, pp. 84-95.

[15] Tsai, H.T., Chang, H.C., Tsai, M.T. Predicting repurchase intention for online clothing brands in Taiwan: quality disconfirmation, satisfaction and corporate social responsibility, In: Electronic Commerce Research, 2016, vol. 16, pp. 375-399.

[16] Blazquez, M. Fashion shopping in multichannel retail: the role of technology in enhancing the customer experience, In: International Journal of Electronic Commerce, 2014, vol. 18, issue 4, pp. 97-116.

[17] Republic of Turkey Ministry of Health, Public Health Agency of Turkey, Healthy Nutrition and Active Life Program of Turkey (2013-2017), 2013, In: $3^{\text {rd }}$ Edition, Ministry of Heath Publication Number: 773, Ankara, Turkey, 81 p. (in Turkish).

[18] The General Secretariat of İstanbul Textile and Apparel Exporters' Associations, Sizes in Apparel, In: Technical Handbook Series Publication Number: 2002/1, 2002, İstanbul, Turkey 86 p. (in Turkish).

[19] Akay, N. Growing Sizes Aggrandize Textile, In: Tekstil İşveren Journal, 2015, issue: 416 - November 2015, pp. 32-35 (in Turkish).

[20] Akgöz, E. The factors that affect the design of plus-size, 2005, Gazi University, Institute of Education Sciences, Department of Apparel Industry and Fashion Design Education, Master Thesis, 135 p. (in Turkish).

[21] Bayraktar, F. Setting the standardization for body size to be employed in the production of clothes for plus-size women, 2007, Gazi University, Institute of Education Sciences, Department of Apparel Industry and Fashion Design Education, PhD Thesis, 202 p. (in Turkish).

[22] Safa, S. The difficulties that plus-size women consumers who accommodate in mediterranean region have to come across in apparel products, 2007,Gazi University, Institute of Education Sciences, Department of Apparel Industry and Fashion Design Education, Master Thesis, 112 p. (in Turkish).

[23] Aktaş, N. Problems encountered by the customers in plus-size women clothes and customer expectations, 2008, Selçuk University, Graduate School of Social Sciences, Department of Apparel Industry and Apparel Arts, Master Thesis, 99 p. (in Turkish).

[24] Süller, B. Fit and design improvement for plus-size clothing: Overview in Turkey, 2014, İzmir University of Economics, The Graduate School of Social Sciences, Design Studies Master's Program, Master Thesis, 142 p.

[25] Maraba, B. Problems in plus-size women's clothing and suggested solutions, 2014, Haliç University, Graduate School of Social Sciences, Department of Textile and Fashion Design, Master Thesis, 168 p. (in Turkish).

[26] Cole, L. The effects of visual and written fit information on plus-size women's perceived fit risk, purchase intention and loyalty intentions in internet apparel shopping, 2009, Virginia Polytechnic Institute and State University, Department of Apparel, Housing and Resource Management, Master of Science Thesis, 108 p.

[27] Turkish Statistical Institute, Statistics of Address-Based Population Registration System, http://www.tuik.gov.tr/ PreTablo.do?alt_id=1059 (Access Date: May 2015) (in Turkish).

[28] Republic of Turkey Ministry of Health, Obesity Incidences of Turkey, Turkish Nutrition and Health Investigation Research - Preliminary Study Report, http://beslenme.gov.tr/index. php?lang=tr\&page=40 (Access Date: May 2015) (in Turkish).

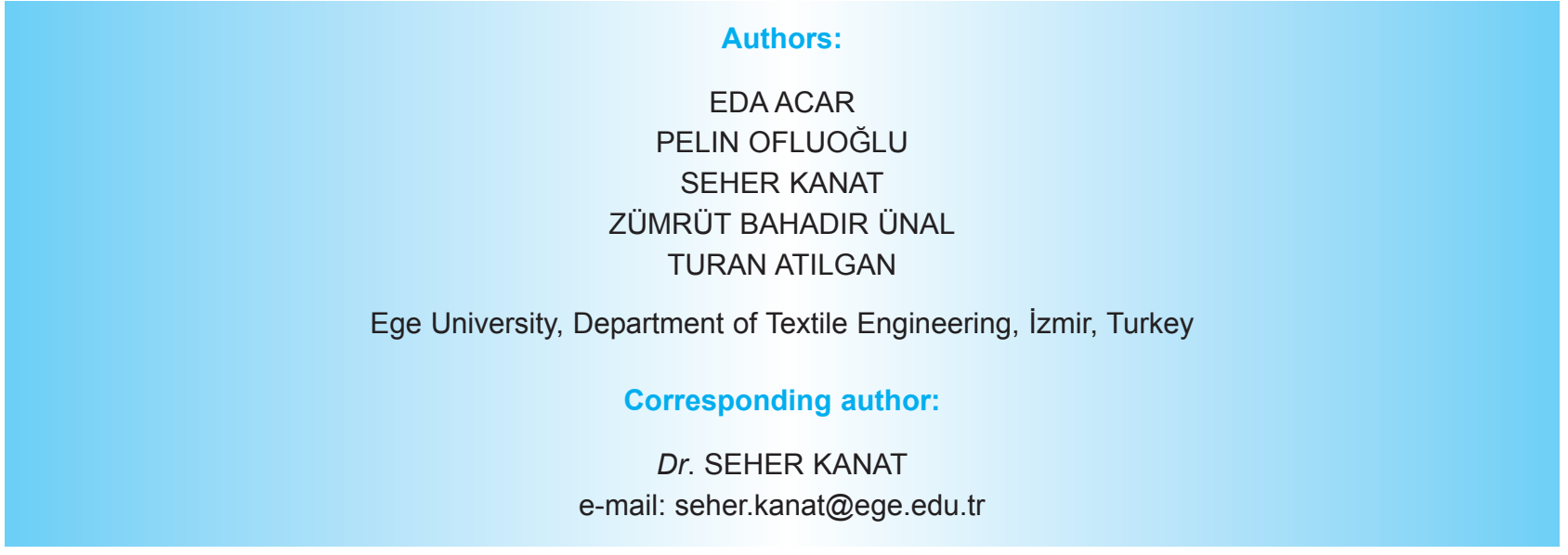

